Portland State University

PDXScholar

1988

\title{
An Analysis of Kindergarten Children's Use of a Word Processor in Their Print Literacy Development
}

Paul Steger

Portland State University

Follow this and additional works at: https://pdxscholar.library.pdx.edu/open_access_etds

Let us know how access to this document benefits you.

\section{Recommended Citation}

Steger, Paul, "An Analysis of Kindergarten Children's Use of a Word Processor in Their Print Literacy Development" (1988). Dissertations and Theses. Paper 1146.

https://doi.org/10.15760/etd.1145

This Dissertation is brought to you for free and open access. It has been accepted for inclusion in Dissertations and Theses by an authorized administrator of PDXScholar. Please contact us if we can make this document more accessible: pdxscholar@pdx.edu. 


\title{
AN ANALYSIS OF RINDERGARTEN \\ CHILDREN'S USE OF A WORD \\ PROCESSOR IN THEIR \\ PRINT LITERACY \\ DEVELOPMENT
}

by

PAUL STEGER

A dlssertation submitted in partlal fulfillment of the requirements for the degree of

\author{
DOCTOR OF EDUCATION \\ In \\ PUBLIC SCHOOL ADMINISTRATION AND SUPERVISION
}

Portland State University

(C) 1988 
TO THE OFFICE OF GRADUATE STUDIES:

The members of the Committee approve the dissertation of Paul Steger presented December 3, 1987.

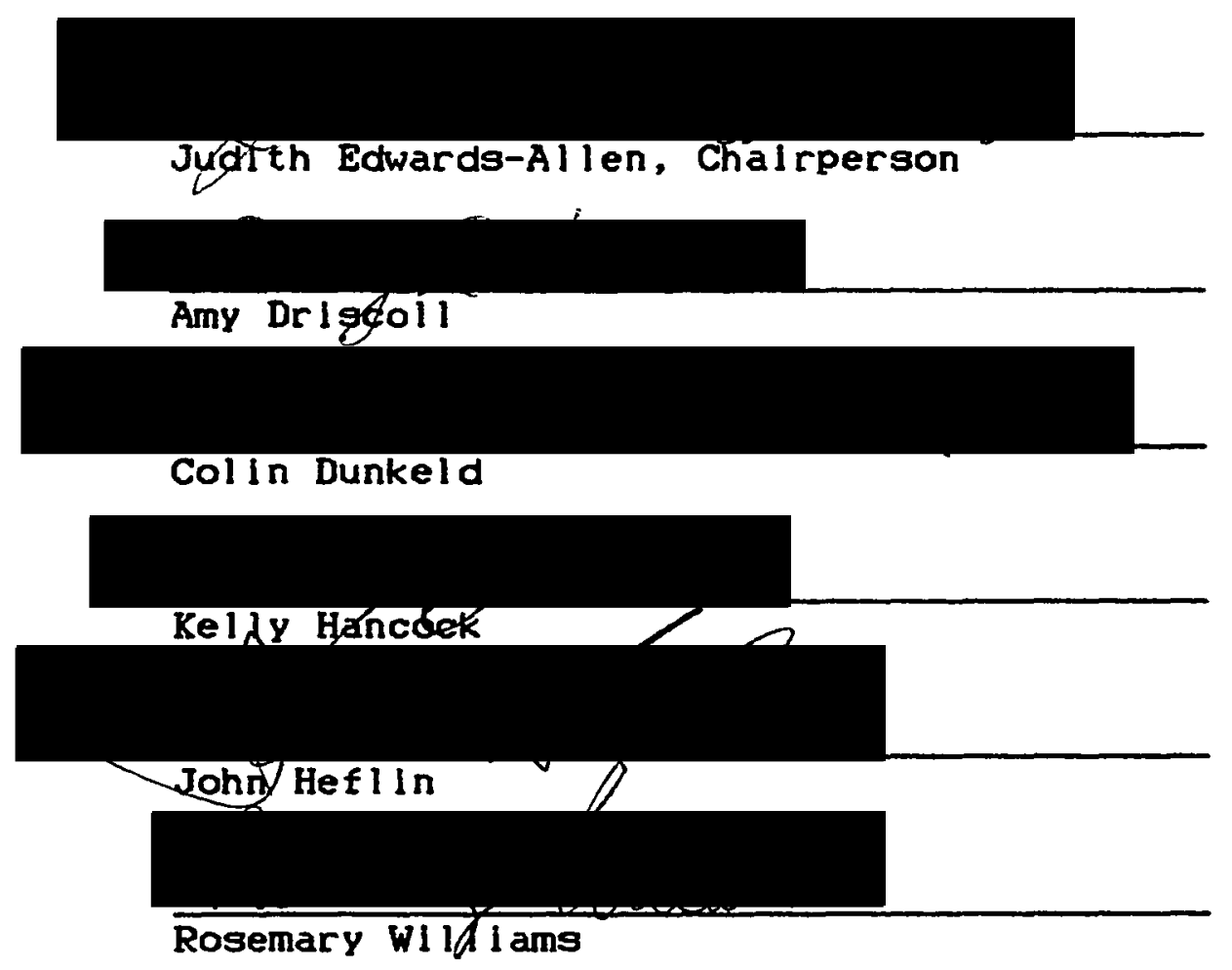

APPROVED :
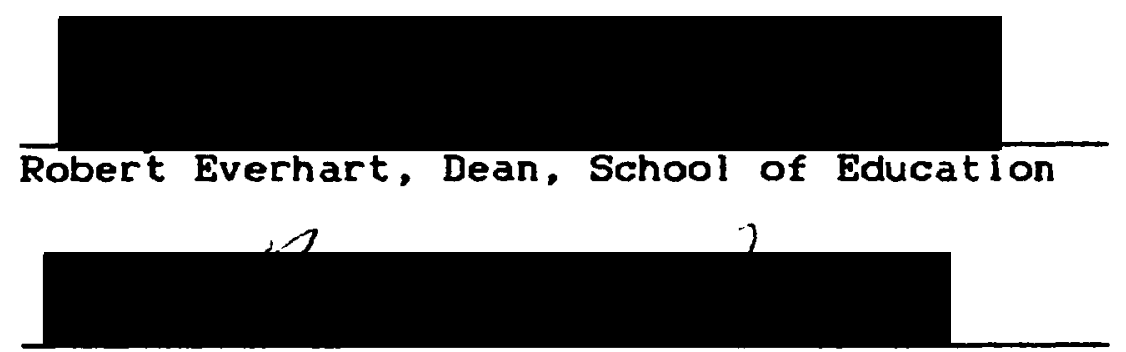

Bernard Ross, VIce Provost for Graduate Studles 
AN ABSTRACT OF THE DISSERTATION OF Paul steger for the Doctor of Education In Educational Administration presented December 3, 1987 .

Title: An Analysis of Kindergarten Children's Use of a Word Processor in Their Print Literacy Development.

APPROVED BY MEMBERS OF THE DISSERTATION COMMITTEE:

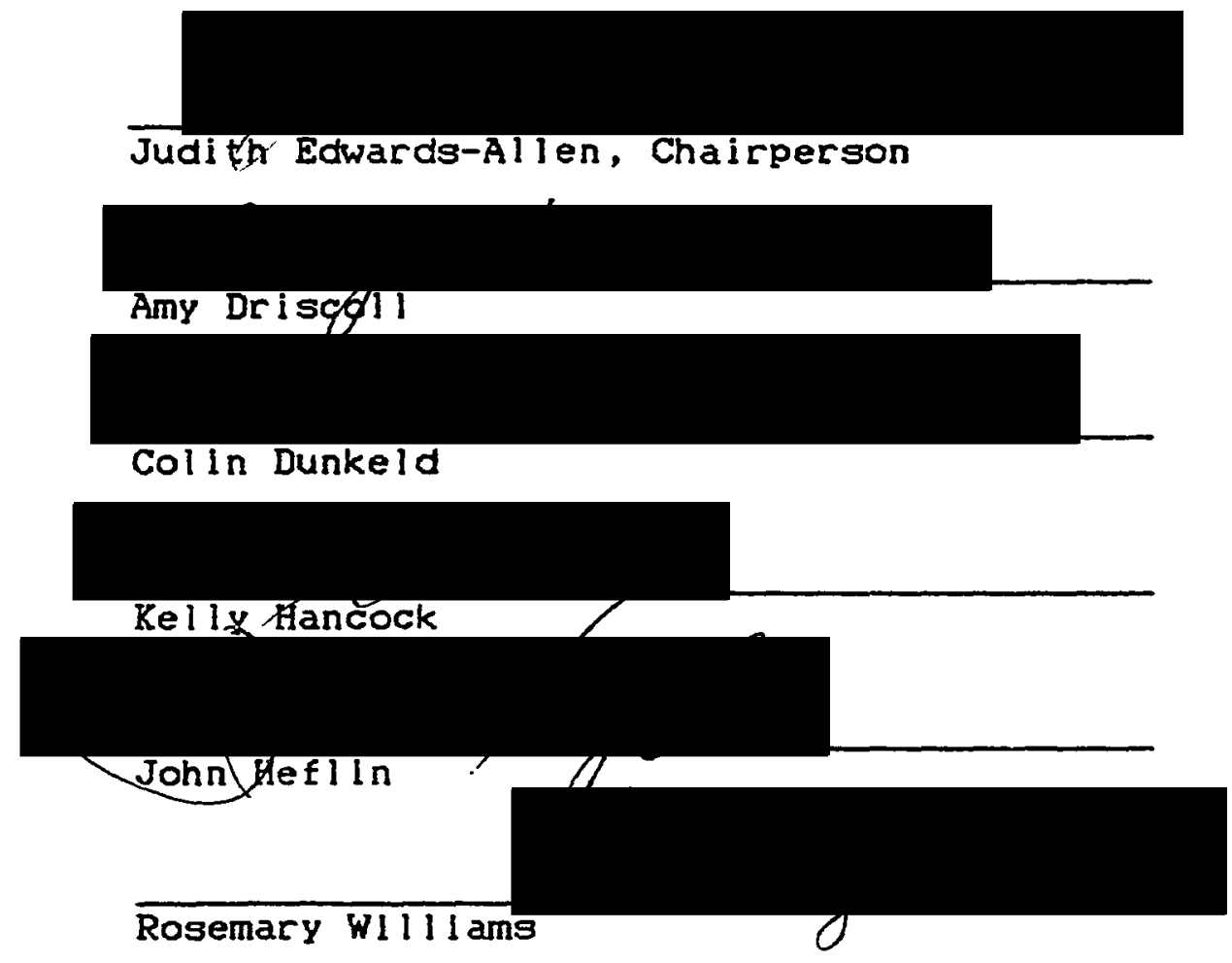

Many young children appear to take delight in manipulating common elements of thelr environment, e.g., stlcks, stones, and mud. Our ancestors also used these and other elements in order to play, explore, and eventually 
create written language. In a print-laden society, young children are budding literates. Within a few years their abilities and skills evolve to the level it has taken the human species thousands of years to reach.

Associated with the evolution of written language is related technology. Humans have evolved from cave art and literacy to computer art and Iiteracy. Again, what has taken thousands of years to evolve for the species takes only a few years for today's children. Within the past ten years computers have become common literacy implements in American schools. An understanding of childrens' use of this machine is Important to educators in general and educational leaders In partlcular.

The purpose of this study was to investlgate kindergarten students' use of a word processor: What developmental sequences related to print 1 iteracy reveal themselves as kindergarten children use a word processor? In what ways are these sequences the same or different than those Ident 1 fled by researchers studylng young chlldren's use of pencll and paper? What time commitments do chlldren make at each stage of these developmental sequences? How do the physical attributes of the computer environment, screen color for example, Influence children's behavior assoclated with word processing?

A revlew of I Iterature Incorporated readings associated with research in human evolution of print literacy, Iiteracy 
of technology, language and cognition plus recent research on writing and computers.

A research design incorporating qualitative methods was created. Six subjects, representing a variety of backgrounds in a kindergarten class of 26 full day students, were observed for 20 weeks. For one hour each day, this kindergarten class attended a writing lab wich contained eight learning centers. One of the learning centers consisted of slx word processors networked to two printers. In addition to collecting student documents, both in paper and electronic form, subjects' behaviors were observed and recorded. Observatlonal recordings were analyzed, collapsed into manageable data, and re-analyzed.

Subjects' evolution of writing was simllar to children using pencil and paper. In addition, subject's literacy of technology evolved. Each subject displayed Individual eplsodes of development and incorporated less mature behaviors with more mature behavlors as they evolved along their print 11 teracy and 1 iteracy of technology cont 1 nuums. It was observed that subjects Intertwined print and technologlcal behaviors and skllls as they wrote with a word processor.

Time relationshlps assoclated with the development of wrlting and environmental aspects of the word processor center did not appear important. Information Age etlquette 
evolved as students controlled their writing, a computer system, and worked with others. The inherent publicness of monitors contributed to meta-lingulstics, sharing knowledge about technology, and problem solving among students.

Young children are capable of writing with and manlpulating a word processor. They are also capable of trylng to solve problems of wrltten language and computers. Educators will find that young chlldren quickly learn Information Age tool etiquette. 
To MY Eam $11 Y$ 


\section{ACKNOWLEDGMENTS}

Many special thanks to all of the children who have partlclpated In Sabin's kindergarten and grade one classrooms during the last $f$ ive years. It has been a pleasure watching students blassom as print literate individuals. A special ingredient to their flowering literacy has been their contact with the many excellent members of Sabin's staff. In partlcular, this study would not have been started or completed without the assistance and cooperation of Carmen Barnett, Brenda Bartell, Yvonne Berry, Kathy Gillaspie, Nancy Gresbrink, Hazel Keasey, Mary Laughlin, Chris Lamp, Lor I Oman or principal, Mike Jordan. I also appreciate the insights and support many parents and other professionals have shared during this perlod of study.

Members of my Dissertation Advisory Commlttee, Amy Driscoll, Col in Dunkeld, Kelly Hancock, John Heflin, Rosemary Will lams and Carolyn Moilanen of Portland Public Schools Evaluation Department have provided much valued assistance, encouragement, suggestions, and guidance. In particular, my advisor, Judy Edwards-Allen has provided continuous support throughout this study.

Finally, speclal thanks to my lovely family. My children Emily and Zachary have given me many hours to observe and appreclate thelr literacy growth. Patricia 
Ferguson-Steger, my wife, has not only provided much encouragement but has been extremely helpful in so many ways. 
TABLE OF CONTENTS

PAGE

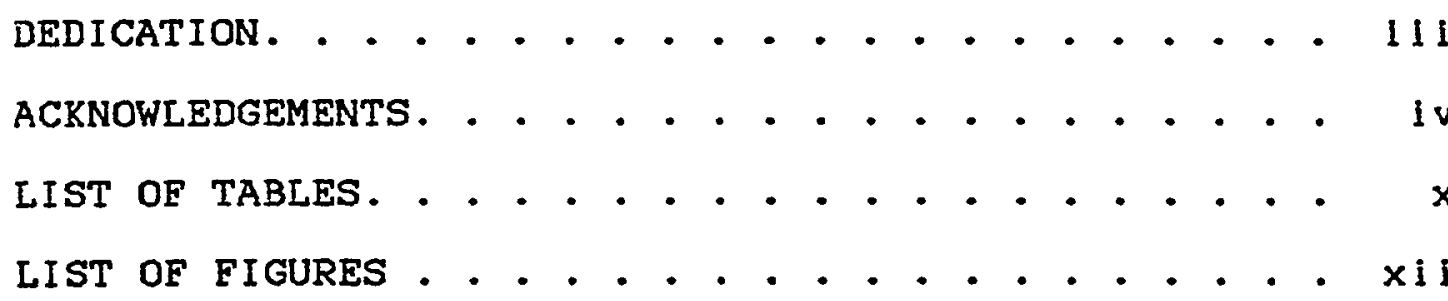

CHAPTER

I INTRODUCTION. . . . . . . . . . . 1

Problem Statement . . . . . . . 4

Purpose of This Study . . . . . . . 9

Study Statement . . . . . . . . 15

Questions

Study Organization. . . . . . . 16

II REVIEW OF RELATED LITERATURE. . . . . . . 18

Introduction. . . . . . . . . . 18

Prehistorlcal And Historical

Perspectives On Literacy........ 18

Oral Communlcation

Chronological Development of

Literacy Tools

Relationshlp of Literacy To Its tools

Language And Cognitive Development. . . 35

Literacy. . . . . . . . . . . 44

Writlng Research........... 51

Computer Research Related To Writing. . 67 
Summary . . . . . • . . . . . . . . 83

II I RESEARCH DESIGN AND METHODOLOGY • • • • • . 85

Introduction. . . . . . . . . . . 85

Research Procedure. . . . . . . 88

Particlpant Observation . . . . . . 92

Preliminary Research Activities . . . . 94

Research SettIng. . . . . . . . . 97

Research Subjects . . . . . . . . 101

Data Collection .. . . . . . . . 102

Data Collection Instrumentation . . . 105

Data Analysis... . . . . . . . . 111

Research Time Line. . . . . . . . . 113

IV PRESENTATION AND ANALYSIS OF DATA • • . . 115

Introduction. . . . . . . . . . . 115

Scenario Explanation

Data Collection

study statement . . . . . . . . . 122

Questions

Presentation And Analysis of Data . . . 123

Question - 1

Questian - 1a

Qual ltat Ive Research Analysls And

Presentation of Questions. . . . . 138

Collapsing, Analyzing, \& Presenting • . . 138

Coll apsing And Analyzing

Print Li teracy

Literacy of Technology

Mlxed Literacles 
vi i i

Social Behaviors

Soclal Behaviors Related To

Print Literacy

Social Behaviors Related To

Literacy of Technology

Self Talk

Quest ion - 1b

Question - 2

Additional Findings . . . . . . . . 197

V. SUMMARY, FINDINGS, CONCLUSIONS, AND

IMPLICATIONS. . . . . . . . . . . . 200

Summary . . . . . . . . . . . . 200

Restatement of The Problem

Study statement

Flndlngs. . . . . . . . . . . 203

Subject's Print And

Technological Sequences

Pencil, Pen, And Paper System --

Computer System

Subject's Time Commitments

Influence of Computer

Environment Attributes

Other Findings . . . . . . . . . . 214

Keyboarding

Key Rubbing

CAI vs. Word Processing Software

Authorshlp of Word Processed

Documents

Control

Publ icness

Meta-Lingulstics

Information Age Etiquette

Cognltion

Gender Differences

Conclusions . . . . . . . . . 232

BIBLIOGRAPHY. . . . . . . . . . . . . 237

APPENDICES. . . . . . . . . . . . . 262

Appendix A - Data Recording Instruments. . . . 262

Appendix B - Data Analysis Instruments . . . . 267 
Appendix C - Literacy Development Data Bases . 271 Appendix B - Qual itative Coll apsed Data. . . . 277 Appendix E - Time Analysis Spread Sheets . . . 288 Appendix E - Time Analysis Data Bases. . . . . 295 Appendix G - Computer Choice Data Bases. . . . 302 Appendix H - Printer Data Bases. . . . . . . 308 Appendix I - Letter Choice Data Bases. . . . . 314 Appendix J - Subjects' Ages. . . . . . . . . . 320 Appendix K - Generic Parent Consent Forms. . . 322 AppendlX L - Study Calendar. . . . . . . . . . 325 


\section{LIST OF TABLES}

TABLE

PAGE

I Duration of Data Collection Period and Disk

Memory Storage for Anecdotal Journals . . 120

I Individua! LIteracy Development Charts Data

Collapsed into Flve Categories. . . . . 130

II Composite of Collapsed Data Displaying

Frequency Percentage of Print LIteracy and

Literacy of Technology Behavlors with each

Opportunity to Use a Word Processor . . . . 143

IV Compilation of Recorded Time in Minutes

Related to Subject-Speciflc Eplsodes of

Print Literacy Evolution Documented in

Table II for Martha, Christy, and Rachel. 162

$V$ Compliation of Recorded Time in Minutes

Related to Subject-Specific Episodes of Print

Literacy Evolution Documented In Table II

for Dave and Mark. . . . . . . . . . . 163

VI Data Base Deplcting; Month of Study, Monthly

Time, Cumulatlve Time, Monthly Average

Time, and Cumulative Average TIme of

Subjects' Involvement with Word Processors. 170

VII Composite of Subjects' Word Processor Cholce . 181 
VIII Percentage of Subjects' Word Processor

Choices. . . . . . . . . . . . 183

IX Composite of Subjects' Letter form Cholce

Percentage . . . . . . . . . . . . . 194

X Data Base Display Indicating Dave's Letter

Form Choice. . . . . . . . . . . 196

XI Data Base Display Indicating Mark's Letter

Form Choice. . . . . . . . . . . 197 


\section{LIST OF FIGURES}

FI GURE

PAGE

2.1 Two of Marie Clay's (1975) Arbitrary Rating

Scales from Her Book What Did I Write?,

Subtitled "Beginning Writing Behaviour."

2.2 Writing Behaviors of Children In A Print-Laden-

Society. This Author's Interpretation Based

Upon Readings And Observatlons.

3.1 Example of Donald Graves's Writing Research

Study Deslgn.

3.2 Example of Guba's and IIncoln's (1981) Figure 4.

A Typology of Subject/Observer Relatlonships.

3.3 Time LIne Display of the Three Data Collection

Components to this Study. Data Collection

was Confined to the Word Processor Center

In the "Writing Lab."

3.4 Dlagram of Sabin's Writing Lab Deplcting

Learning Centers and Position of the

SIX Word Processors.

3.5 Sample Section of Monthly Report Form.

3.6 Sample Section of Dally Case Study Group Data

Collection Form.

3.7 Sample of Dally Case Study Data Collectlon Form. 108 
3.8 Sample of LIteracy Development Chart Form.

3.9 Sample of Individual Subject Writing Behaviors Data Base and Explanation of Terms.

3.10 Sample of Publishing Chart Data Collection Form.

4.1 Developmental Sequences of Print Literacy Using

a Word Processor.

4.2 Selected Samples of Martha's Writing with a Word Processor, January through June 1987 , Il lustrating her Print Literacy Development.

4.3 Data base of Martha's LIteracy Development Chart Showing her Print Literacy Growth During the Study.

4.4 "Dilly-Dallying" Examples of Sklll Behavlors, and Understandlngs of Print Llteracy and Llteracy of Technology.

4.5 Writing Behaviors of Children. A Composite of Varlous Authorities and My Interpretation of Behaviors Assoclated with the Evolution of People's Writing in a Print Laden-Society.

4.6 Development of Writing In Chlldren. Composite of Flgures 4.1 and $4.5 \mathrm{Displaying}$ the Intercelationship Between the Original System. 135

4.7 Martha's Word Processor Written Product for March 16, 1987. 
4.8 Definitions of Qualltatively Arranged and Coll apsed Data Categories.

4.9 Examples of Subjects' Word Processor Products Representing "Gobbledygook," "Copying," and "Writing."

4.10 Graph of SubJect's Average Monthly Time at Word Processor Recorded in Minutes.

4.11 Data Base Deplcting Mark and Rachel Screen Preference.

4.12 Graph of Subject's Choice of Color or Monochrome Screen.

4.13 Diagram of Word Processor Center.

4.14 Display of Dave's Computer Choice Data Base.

4.15 Composite of Subject's Involvement in the

Printing Process During the study.

4.16 Display of Christy's Printing Behaviors Data Base.

4.17 Display of Mark's Printing Behaviors Data Base.

4.18 Display of Relevant Data from Dave's Data Base.

4.19 Graph of Subject's Letter Cholce Form. Conv. In

Rachel's Sectlon Refers to Conventlonal

Letter Format. 


\section{CHAPTER I}

\section{INTRODUCTION}

A del lght for many chlldren attendling preschool or day care is finger painting. With special paper and paint, children have llcense to squash, spread, squeeze and explore this medium. When the spreading medium is pudding or shaving cream, addltional senses are involved. Before we had shaving cream, pudding, and finger palnt avallable in our culture, children used mud and other moist materlal (many still do) for exploring and play. As children grow older and become more sophlsticated, they learn about and explore with new medla and technologles, e.g., crayons, pencils, or pens on dlfferent types of materials, including paper.

Such early play with spreadable medla has not always been the sole domain of chlldren. There is evldence, dating back more than 25,000 years, of finger motlons with a medium whlch produced drawings of spaghetti-like motifs on cellings In caves Inhablted by our Cro-Magnon ancestors (Marshack, 1975). Mud play (exploration) by young chlldren and the subsequent drylng of this material may be a reflection of our ancestors exploring and creating with a similar medla before Inventing the technology of clay tablets for record keeping. 
Young chlldren evolve from spreading thlngs, drawling, and marklng walls to focusing their plctorlal and visual media exploratlons on paper and more culturally accepted forms of expression. Thls is simllar to human evolution as we have moved from cave walls to papyrus to parchment to paper. As the human specles has evolved, we have invented, discovered and explored with new media and technologles. As children develop, they invent, discover and explore new media and technologles. Print literacy is an evolutionary component of the human specles' growth and development and can also be an evolutionary component of an Indlvidual's growth and development. This mirror image of an Individual's literacy evolution reflecting our specles' 1 iteracy evolution is simllar to the blologlcal expression "ontogeny recapltulates phylogeny."

It has taken thousands of generations for the human specles to evolve to Its present state of oral and written language. Today, an Individual specles member completes $\mathrm{hls} /$ her language development in one generation. Our ancestor's inltial communlcation may have conslsted of non-verbal body language. Soon after and or in conjunction with body language evolved oral language. Later in our specles' evolution there was a need for the Invention and development of written communlcation. This human specles evolution of communlcation 19 commonly repeated by Indlvidual species members today. Except in speclal cases, each human 
has the facllity to develop oral and written language capabllitles.

Iuria (1977/1978) has used the term "cultural skills" In reference to children developing number and ietter concepts. In our present soclety, we use the terms "literate" and "Ileracy" to connote the abllity of an Indlvidual or people to understand and use numbers and letters to read and write. In many cultures throughout the world, llteracy skll1s asslst people in their dally living (Hall 1959). Of the four billion people populating the earth, over three billion are Ii terate.

Accordlng to many authorltles, there are four major components to IIteracy: speaking, Ilstening, reading, and wrlting (Holdaway, 1979, 1984; Goodman, 1984; Oxenham, 1980; Smlth, 1984; Stubbs, 1980). A narrower perspectlve of literacy I deflne as print literacy. "Print IIteracy" refers to the abllity to read and or write cultural symbols ce.g. hearts, ralnbows, skull and cross bones, etc.) and language sound symbols (e.g. letters, syllables, words, etc.).

When consldering print literacy evolution and the skills necessary for wrltten communlcation, a question arlses of whlch skill came flrst, reading or writing? This is simllar to the question, "Whlch came flrst, the chlcken or the egg?" Oxenham (1980) writes: "Although in historlcal sequence, wrlting necessarlly preceded readling - the code had to be Invented before decoding could occur - the latter is much 
more widely practlsed." In the partlcular clrcumstance of the development and evolution of 1 iteracy, reading and wrlting, as well as 1 lstenling and speaklng skllls, are Intertwined, not linear as with the chlcken and egg.

Interrelated with the evolution and development of literacy for both the human species and Individual members of the species is associated technology. In reference to wrlting, Oxenham (1980) states: "... the operation demands at least two articles, the material on which the script is to be marked and the instrument with which the marking will be done." In order to produce a literate ltem, one must have an implement to write with and something to write on and, if necessary, a substance whlch wlll leave a mark.

\section{PROBLEM STATEMENT}

A major aspect of the evolution of 11 teracy has been development of associated technology. Movement along the 1 Iteracy cont Inum is directly related to the Invention and development of literacy tools. Earliest tools were composed of Items from nature, anlmal flulds, plant materlals, stlcks and clay. Through thousands of years of evolution, human visual perception of technology assoclated with written language products has moved from one of diuturnity, being continuous or lasting, to that of ephemerallty, lasting temporarlly. Print literacy tools have moved from cave walls and clay tablets to 1 lght dots and electronlc non-visual 
storage. The latest literacy tool associated with the Information Age is an electronic machine, the computer. Computers programmed with word processing software are now belng made avallable for young chlldren to use as literacy tools (Daiute, 1985; Guttinger, 1986; Wallace, 1985). However, there are those who questlon this writing tool Innovation and freely share their oplnions in words and print. In the opening chapter of Computers and Llteracy, Danlel Chandler (1985) shares the following conversation:

$T$ : You really ought to use this thing. Once you've plcked it up you can stop worrying about not being able to remember things: it does it for you! You'd be amazed at the clever things you can do with it: you'll discover talents you didn't reallze you had. And you'll reallze how wlse you were to try it.

A: It's a fasclnating invention. But I'm afrald I've never belleved that those who sell an ldea are the best Judges of its worth. People who use this thing will become dependent on 1 t and soon they'll stop thinking altogether. I know that there'll be lots of people who'll say that anyone who can use it is brilliant, but just owning a way of storing vast amounts of Information doesn' $t$ make you clever, does It? Will people know how to use it that's the question? And what kind of world would it be If everyone was dependent on this klnd of thing?

S: Exactly. You can't really learn anythling from using it: all it can do is tell us what we already know.

$P$ : Qulte right.

S: At least if you ask a person something you've a falr chance of having a useful conversation. If we have to use this thing there'll be only one answer to each question, regardless of who asks it and whether they understand the answer. And what about people who abuse the system: how could we protect the information we put into it? 
P: I couldn't agree more. (p.1)

similar conversations have been repeated many times within the past 5 to 10 years. When reading this conversation one may well be struck by the dlvergent views held by the varlous speakers concerning their topic of discussion. One notlces a definlte hesitation by three of the speakers in accepting this new phenomenon. The other speaker appears supportlve and shares his/her enthusiasm. Their conversation Includes little fact, mostly opinion concerning its use and how it will affect those who employ 1t. Although this conversation was recorded by Plato almost 2500 years ago, It could easily have been taped within the last decade. In thls conversation, a teacher is discussing and rejecting a technology which you, the reader, use at this moment. Socrates is explalning how this new technalogy will make people stop thinking and that 1 will ruln their minds. The toplc of conversation is written language; the particlpants are dlscussing this new technology of the Iron Age.

Similar to today's common hesitation in readily accepting Information Age technology, Socrates and the other particlpants only speak from their own subjective opinions. Most of today's conversatlons related to the use of computers, and partlcularly chlldren's use of computers, are based upon subjectlve oplnion. Brldwell and Duln (1985) write: 
While test Imonlals abound concerning the ways computers have changed people's I ives as writers (Nancarrow, Ross, and Bridwell, 1984), we don't yet know whether these changes make them better writers or just better producers of pollshed manuscripts. We don't know whether computers contribute to new ways of thinking during wrlting or just new ways of manipulating sentences, paragraphs, and 'files' (p. 115).

Students have had little access to computers and young children even less. There have been very few studles focused upon young children's use of computers and even less centered upon their use of word processors and print literacy. Dllion

\title{
(1985) shares:
}

\begin{abstract}
If we wish to learn about the role of computers in chlld literacy and thelr effect on children's learning and 'l anguaging', we' 11 need to spend much time in classrooms with children and computers to study closely and carefully what happens there. Desplte the amazlng degree of interest in cosputers, I have found very little work descrlbing and analysing what actually happens with them in classrooms, partlcularly from the soclopolitical context of language and learning ... (p. 102).
\end{abstract}

Varlous authorltles have written of the Computer Revolution [Information. Telecommunlcation, Dlglta) Technology, etc. Ages, Clvillzations, and Revolutions) rivaling that of the Industrlal Revolution (Crlchton, 1983; Lias, 1982; Masuda, 1983; Rosenbrock et al., 1981; Toffler, 1980; Vallee, 1982). Others have shared that the Invention of the computer may have as vast an impact upon the human specles as the printling press (Evans, 1979; McLuhan, 1962; Oxenham, 1980). This is no doubt the flrst $t$ ime in human hlstory that soclety has had forewarning of posslble change 
due to a radically new technology. The last quarter of the 20th Century is an opportunity for our society to investigate the use of computers (Marlen, 1983). In partlcular, we have the opportunlty to Investigate chlldren's use of a word processor as they progress along their Indlvidual evolving literacy continuums. This research based knowledge wlll assist leaders in helping to provlde direction in education. It has been suggested that leadership is an Imperatlve component to effectlve schools (Brookover, Beamer, Elthim, Hathaway, Lezotte, Mlller, Passalacqua, \& Tornatsky, 1982; Natlonal Committee for Citlzens in Education, 1980; Serglovannl, 1984), Further, It has been proposed that principals provide guldance in our nation's schools by assuming a role of instructional leadershlp (NCCE, 1980). others support thls position; in Becoming a Nation of Readers, the authors (1985) write: "Schools that are especlally effectlve in teachling chlldren to read are characterlzed by vlgorous Instructional leadershlp" (p. 112). At a symposium held early in thls decade (NCCE, 1980), It was suggegted that in relationship to curriculum and Instructional leadershlp,"... basic literacy, communication skills, arlthmetlc skllis, and the abllity to thlnk, reason and solve problems were necessary outcomes if a school were to be considered effectlve" (p. 35). These outcomes are directly related to print 1 iteracy. 
In order to provide approprlate leadershlp to facllitate an effective school, the principal andror other educational leaders should have a strong understanding of the curriculum and instruction. An example of this curricular understanding is presented in Becoming a Nation of Readers (1985): "Instructional leadershlp in reading entalls a considerable amount of speclallzed knowledge and experlence" (p. 112). The Importance is apparent that educational leaders possess an excellent understanding of print literacy.

Now that we have entered the Information Age, educational leaders must have an understanding of related currlculum, instruction, cognltive development and associated literacy tools. In the world's industrialized countries, chlldren are no longer becoming thinkers of the Industrlal Age, they are becoming the first cognitively aware generation of the Information Age. It is therefore Imperatlve that today's educatlonal leaders have an understanding of how chlldren think, function, and become literate in the Information Age.

\section{PURPOSE OF THIS STUDY}

The major use of computers with chlldren has been as drillmaster. Scollon and Scollon (1984) wrlte: "The predominant use of mlcrocomputers for chlldren is in drill and practlce rout Ines" (p. 135). However, teachers have 
increasingly begun to employ application software, data bases, spread sheets, and word processing programs in classrooms. In many settings, students do not begin "serlous" word processing until the thlrd or fourth grade (Georgas, 1984). Georgas reports that Janet Kane, a researcher on the Bank Street project, has stated: 'There's nothing inherent in the word processor that prevents $k$ lds from doing it earlier' (p. 133).

There has been relatively little investigation reported as to the use of this new technological tool in the evolution and development of literacy (Collins, 1985; Daiute, 1985; Flsher 1983, Kurth \& Stromberg, 1984, Shelngold, Kane, \& Endrewelt, 1983). Typical of the comments one reads in varlous professlonal Journals is the followlng by Jon Madlan (1986),

Word processing used in conjunction with sound princlples of Instruction is revolutionizing how students learn to read and write. Many of the most Influentlal, humane curriculums, from Dewey through The National Writing Project, Poets-In-the-Schools and language experlence movement, can achleve much finer articulation when supported by word processlng (p. 17).

However, there is a great deal we do not know about using computers with chlldren. Cromer (1984) wrltes: "The many educational areas that may beneflt from computerlzed Instruction have yet to be scientiflcally studied" (p. 25).

Not all computer authorltles have welcomed the Information Age Into classrooms (Welzenbaum, 1983). Among 
many questions is one concerning appropriateness of using computers wlth young chlldren, Joseph Weizenbaum (Brady. 1985) has articulated this concern in a recent interview: ... I don't think that we should use an entire generation of Amerlcan school chlldren as experimental subjects. Of course, experiments should be carried out to help determine, among other things, what actually can be accomplished with computers and chlldren, but these experlments ought to be small--involving one school here, another there. To use the entire school population of the United States as experimental subjects is at the very least reckless (p. 25).

The vast majority of articles appearing in professional journals are based on oplnions, limlted observation, and subjective Intultion. Iittle research or investigation has been conducted in the area of young chlldrens' IIteracy development and use of a computer as a word processing tool. Many scholars have called for further research Into the use of computers with students (Bruce, 1985; Dalute, 1985; Kurth \& Stromberg, 1984; Newman, J., (1984); Sommers, 1985; Weizenbaum, 1983). Bridwell and Duin (1985) have written: "... we don't have sufficlent research data to demonstrate that computers are much more for writers than ultra-fancy typewrlters and personal printshops" (p. 116). Clark (1985) writes:

The need now $1 \mathrm{~s}$ for extended studles to examlne preclsely what happens when a word processing facllity is avallable." "What happens when words 'dance in light' and you can 'swim through text' to quote two alternative metaphors for the llberating effect of word processing (p. 20). 
The following is taken from a recent report (Tech Central, 1986) to the U.S. Secretary of Education (the flrst report of the Department of Education or of any other national task force to be published electronlcally before beling published In print):

Research and development are needed to understand the cognitive and affective consequences of the new Information technologies and to guide their development and application in educational settlings ( $p .13$ ).

Judl th Newman (1984B) has phrased speclfic quest lons concerning wrltten language learning and computers:

There are a number of cruclal questions we need to ask about software and computer-based language learning activities:

What role does the computer play in these learning exper lences?

What is the teacher's role?

To what extent does this software let learners take control of thelr own learning?

Does it facllitate a sharling of knowledge? ( $p .762$ )

Spencer and Baskin (1983) have formed some quest lons

about the use of word processing relating them directly to

early chlldhood education:

When is a child old enough to effectively use a word processing program to type letters of the alphabet, numbers, and other symbols? At what polnt can a word processor ald a chlld in beglinning to write simple sentences, paragraphs, storles, or poems? There are no easy answers to these questlons: a chlld's maturlty, capability to ldentlfy keys, and the avallability of adult asslstance in teaching use of the program are all factors in determining when word processing can be successfully introduced ( $p .21$ ).

The present study, by providing an inltial Investlgation Into chlldren's early 1 iteracy development assoclated with 
computers provides an understanding to similar questions. Through the observation of kindergarten children and their use of a word processor, thls study provides an understanding as to how and if young students can use this new 1 iteracy tool. Reported findings also provide those assoclated with the field of early childhood education a better understanding of using computers with young students.

In addltion, researchers need to conslder that our society and culture are rapldly changlng as we approach the 21st century. School administrators and others associated with educational adminlstration must consider moving beyond the "status quo" of the past and prepare for the future. Early in this decade Culbertson (1983) wrote:

Adminlstrators, Including those in education, must confront the future if they are to lead. Their leadership role, however, is not that of effective predlction but, rather, that of shaping and of even helping lnvent the future. Those who lead need a vision of the future, buttressed by understandings of socletal change ( $p .273$ ).

Research in the fleld of educational administration can provide guldance to school adminlstrators as our soclety is drawn more fully into the Informatlon Age. Flndlngs from this investlgation wlll be useful to teachers and researchers as well as educational leaders. Cromer (1984) wrltes: "Princlpals need much more than Just a passing knowledge of technology if they are to translate the future Into today's school rooms" (p. 46). 
There are many unanswered questions as education continues to evolve from the Industrial Age Into the Information Age. A challenge to educators in general and school administrators in particular is to provide quality opportunities and a relevant education for our blooming youth. Culbertson (1983) wrltes:

... an Important task facing leaders is that of assessing the degree to whlch schools are currently pursuling objectives that reflect the needs of the declinlng industrlal soclety and the degree to whlch they are IInked to the needs of an expanding information society (p. 282).

As we continue to evolve into the Information Age, school administrators will find scholarly written theoretical and practical research studies in education and particularly educational administration extremely useful. It is important for researchers to investigate curriculum and instruction tools of the Information Age in order to provide emplrical knowledge whlch can be used for guldance by leaders in education.

This study was conducted in order to provlde a component of emplrical knowledge to the understanding of currlculum and instruction in the Information Age. Young chlldren today are using tools of the Information Age in their evolution of literacy. It seems apparent that such emplrical knowledge of chlldren's use of computers will assist school administrators In their providing leadershlp for students and staff. Further, from the following ilterature revlew to the final 
section in Chapter $V$ titled Impllcatlons, this study provides insight Into the relatlonshlp of print 1 iteracy and the literacy of technology whlch can assist school administrators in quality leadership of currlculum and instruction and consequentlally student achlevement.

The intent of this study has been to observe and analyze young children's behaviors and their products assoclated with the use of a computer system: computer, monitor, printer, and word processing software.

\section{STUDY STATEMENT}

If given the opportunlty, how will chlldren use word processing in their print literacy development during their XIndergarten experlence?

\section{Questions}

1. What developmental sequences related to print literacy reveal themselves as kindergarten chlldren use a word processor?

1a. In what ways are these sequences the same as or different from those ldentlfled by researchers studying young chlldren's use of pencll and paper?

16. What type of time commltments do chlldren make at each stage of these developmental sequences?

2. How do the physlcal attributes of the computer environment influence chlldren's behavior assoclated with 
word processing? For example: screen color or computer location.

The study statement and assoclated questlons have been derived through prellminary investlgatlons and review of relevant 1 iterature assoclated with this research toplc. In order to Investigate these questions, thls study's research design was qualitative in nature. Such a research approach is often employed when studylng a human process (Baghban, 1984, Calkins, 1983; Diesing, 1983; Vygotsky, 1978). In the Preface to Taylor's (1983) book Famlly Llteracy, Dorothy Strickland writes:

The observatlon and analysis of chlldren's 1 iteracy development in natural settings hold exciting promise for the extension of our knowledge of how chlldren become effectlve readers and wrlters and of the contextual factors that may support or constraln that deveiopment.

Writing about research techniques assoclated with writing and the new technologies, Halpern and Llgget (1984) state:

Descrlptive research should Investigate the activities of those who compose in a varlety of ways for a varlety of reasons. Such research $\mathrm{mlght}$ include ethnographlc or naturallstlc studles, case studles including protocol analysis, fleld studies, longltudinal studles, and content analysis of messages ( $p, 82$ ).

\section{STUDY ORGANIZATION}

Following chapter I, Introduction, chapter II, Revlew of Related Ilterature, encompasses a review of literature assoclated with print 1 iteracy and the 11 teracy of technology 
as it relates to the toplc of this investigation. Chapter II I, Research Design and Methodology, describes the research methodology and design necessary to conduct this investigation. Chapter IV, Presentation and Analysis of Data, contalns tables, $f$ lgures, and observational data. Chapter $V$, Summary, Findlngs, and Conclusions, summarizes and concludes this study of young chlldren's literacy evolution assoclated with a word processor of the Information Age. Finally, a Bibliography and Appendlces follow chapter five. The end of the Twentleth Century is a thrilling time for our culture. We are experlencling the beginning of the Information Age. A current rediscovery in Amerlcan education is the wrlting process and its acceptance as an Integral component to literacy. There is much to be learned. Bridwell and Duln (1985) wrlte:

One of the most exclting things about our work is that so little is known--elther about how we humans have produced written language for centuries or about how computers may help us with this unlquely human enterprise in the future (p. 121). 
CHAPTER II

\section{REVIEW OF RELATED LITERATURE}

\section{INTRODUCTION}

This chapter reviews literature related to the evolution of I iteracy, associated technologles, the development of writing in young children, and research involving four to seven year olds and their use of a word processor. There are five major sections contalned in this chapter. The first section is devoted to an overview of the prehistory and history of writing and literacy. This is followed by a section focusing on the development of language and cognition. Literacy is the toplc of section three. The following section about writing reviews recent research concernlng young chlldren's writing development. Computers and thelr use by young children for writing is the topic of the flnal major section In Chapter II.

PREHISTORICAL AND HISTORICAL PERSPECTIVES ON LITERACY

aral Communlation

Lingulsts and others explain that primitive socleties have long practlced oral language tradltlons (Burrows, 1984; More 11, 1985; Stubbs, 1980; Vygotsky, 1978). These 
tradltions assisted our ancestors in passing on their culture from one generation to another (Holdaway, 1979). An important component of these traditions, story telling has long been an art and skill praised and esteemed within cultures. Many people in primitive societies exhiblt amazingly longterm memorles as they tell stories of their people, history and culture (stubbs, 1980). The techniques they use in order to remember such long stories are rhythm and chyme. Holdaway (1979) wrltes: "Chant, song, dance and inguistic rituals are among the most powerful forms of human learnings, primitively satisfylng, deeply memorable, and globally meaningful" (p. 58).

Storles of prominent cultural tradition are told and retold to others in chyme with rhythm. Such a patterned approach assists other members of the society in learning and remembering storles and traditlons. Thls approach of transferring cultural Information from one generation to another has continued as we learn chythmlc songs and rhymes from our parents and share them with our chlldren (Frobel, 1891). Our own language's traditlonal rhymes, found in Mother Goose, were used to pass on culturai traditlons through oral communication. It is suggested that some of these tradltional "...rhymes may be rellas of formulas used by the drulds In choosing human sacrlfices" (Barling-Gould, 1967, p. 12). Today, our children continue thls tradition of 
oral enculturalization through their learning and reciting of rhymes, finger plays and songs.

Oral communication also incorporates many gestures, facial as well as body, plus nuances of voice, rhythm, and volume which print can not duplicate or express. Edward Hall (1959) has written: "In addition to what we say with our verbal language we are constantly communicating our real feelings in our silent language--the language of behavior" (p. 15).

The varlous additional components which we add to our oral language communication are aspects of our own indlvidual cultures. In addition to transferring oral literature and cultural traditlons from one generation to another, we continue the same with oral language gestures and supportive communication skllis. Thls enculturallzation transcends both oral and written language (Hall, 1959).

\section{Chronological Development of Literacy Tools}

Anthropologists and others have debated the significance of prehistoric cave art, artifacts and their attendant markings since their discoveries by modern men and women. Though the debate continues, the polnt is settled that they exist and that they communicate to the casual observer a plctorial representation of the exlstence of certain anlmals and perhaps other items which existed during the life time of the artists and recorders. Among the artlfacts are certain 
drawlngs containing varlous marks, some similar to chevrons, which may represent an attempt at symbolic comnunication (Marshack, 1975).

A long time ago, someone discovered that when clay was marked and allowed to dry, the mark remained. This became a major step for the human species once there was the reallzation that clay in combination with a stick could be useful in producing designs. Later, this concept would be adapted to the invention and production of clay tablets. This invention, combined with the desire to reiain administrative records, evolved into our ancestor's early writing about 6,000 years ago in Mesopotamia.

The papyrus reed had been a major building materlal in Egyptian culture for many years. Egyptlans had been using it In varlous technologles, housing construction, cooking and sailing. Eventually, it was discovered that if papyrus reeds were split, layered In cross directions, wrapped in cloth and then pounded together that a paper-type substance was produced. In place of a stlck, the Egyptlans found that a hollow reed with sharpened point worked better as a writing impl ement.

For thousands of years the versatile papyrus reed was used extenslvely in the development of print literacy. Not only were papyrus reeds used to write on, they were also used as the writing Implement. The form which early print literacy took was that of scrolls. As a result of processing 
papyrus into a medium to write on, long rolls, scrolls became the end product. In order to read a text, an individual had to unroll one end of the scroll while rolling up the other. Papyrus scrolis tended to be somewhat brittle and thus required careful handling. Such technology was not useful for quick referencing or heavy use.

Due to political rivalry, parchment was invented around 170 B.C. in Asia Minor. An Egyptian KIng, Ptolemy VI, cut off the supply of papyrus to his rival King Eumenes II of Pergamum in Asia Minor. By this time in human history written records were becoming a necessity; therefore, a substitute had to be found. The invention of parchment became the answer and an Improvement over the papyrus scroll. Animal skins were speclally treated and prepared as a writing surface. Scribes could write on both the front and the back of parchment. Parchment was produced in separate sheets. It was soon discovered that a number of parchment pieces could be sewn together forming what the Greeks termed "volume," a book. Access to reference materlal became easler.

China was the birth place of paper as we know it. Using mulberry, waste $f$ lsh nets and rags, Ts'al Lun developed a process for making paper in A.D. 105 (Boorstin, 1983). Paper and the knowledge of making paper slowly drifted to the West, eventually reaching Europe when it was brought to Spain by the Moors durling the 14th century. 
While camel and rat halr brushes were used in China and the East, reed pens were the implements of cholce in the West until about 500 A.D. and the invention of the quill pen. Although paper had been invented in China by this time, the qulll pen, invented in Europe, was first used on parchment. The innovation of using sharpened tall feathers from geese and swans, thus Inventing the qulll pen, was a marked improvement over the use of reed pens as writing implements.

Another wrlting implement used during this same time perlod was the pencll. For about a thousand years, pencils had been used in both the eastern and western hemispheres. The modern pencil consisting of a wooden shaft incasing a graphlc-clay core dld not evolve untll the end of the $18 \mathrm{th}$ century. Prior to this, pencils were simply pieces of graphlte wrapped in cloth.

Our ancestors used printing for a varlety of everyday purposes before using it in connection with religion and knowledge. Printed textlles have been discovered in ancient Chlna and Egypt. The Initlal development and use of printing on paper occurred In ChIna. Here the technology was used extensively for religlous purposes. Buddhlst monks ploneered much of the early printing technology. Early printing consisted of carved wooden blocks usually wlth a rellglous motif or an ldeograph from their print language. The general print technology developed by the Chinese gradually moved westward. Playing cards, printed before books, appears to be 
the vehicle supporting the spread of printling technology into and through Europe (Boorstin, 1983).

After the invention of literacy, probably the most important 1 lterate artifact to be produced to date was the Gutenberg Blble. In reference to the change initiated by Gutenberg, Boorstin (1983) writes:

He was a prophet of newer worlds where machines would do the work of scribes, where the printing press would displace the scriptorium, and knowledge would be diffused to countless unseen communities. (p. 510)

Prlor to printing innovatlons masterminded by Gutenberg, printers found it difficult printing text with the carved wood block technology of the early printing era. Gutenberg solved these technological problems with the invention and subsequent development of moveable type and the printing press. He invented a system for producing large numbers of type faces, individual letter pleces of the same relative slze. With large quantities of type pieces avallable, printers could easlly arrange them in special forms for printing. Once the type was invented, the manner of holding them in place and the development of a press followed. The technology of printing developed by Gutenberg did not radically change for the next three hundred years, until the Industrial Revolution. The quallty of paper and printing began to Improve during the 19 th century. In simllar fashion, pens did not change radically untll the Industrial Revolution and the Invention of the steel tip. Although 
there is evidence from Pompeli of bronze-tlp pens dated about 1,000 B.C., they apparently did not become a standard writing implement. Invention of the steel-tip pen in 1780 paved the way for mass production of related writing implements. Fountain pens were developed and improved during the 19 th century. Later in that century, the ball point pen was patented. Modern paper technlques were developed during the later part of the $1800^{\prime} s$. Today's colorful felt tip pens were introduced to the western consumer market by the Japanese in 1964.

The manual typewriter was invented soon after the American Clvil War. In 1908, the first electric typewriter was patented in the Unlted States. Following varlous letter key arrangements, the QWERTY keyboard, deslgned by C. L. Sholes in 1872, became the standard. The QWERTY keyboard was designed to slow typlsts down and reduce the jamming of keys. During the $1930^{\prime} s$, August Dvorak designed his own system concentrating primarlly on increasing efficlency and reducing errors. Although the Dvorak keyboard has received renewed interest in recent years, the QWERTY keyboard remains the industry standard.

The latest 11 teracy tool to be developed by the human specles is the computer. Durling the last quarter of the 20 th century we are witnessing an explosion of Information Age technology. The capacity of the' 40 and ' 50 's mainframe computers is found in today's microcomputers. An early use 
of large mainframe computers was text analysis. They also provided early designs for networking of terminals and printers for word processing. With the growth of microcomputers in numbers and power during the late 1970's and early $1980^{\prime} s$, word processing programs have become more sophistlcated and universally employed. During the later 1980's microcomputers programmed with word processing are a major component of telecommunications and almost instant access to the world.

\section{Relationship of Literacy to its Tools}

Many thousands of years ago our early ancestor's hunting and gathering socleties evolved the capacity to recognize quantity. Following the hunt or gathering of food stuffs, harvested supplies were distributed among group members. As these groups grew in number and individuals became more speciallzed in thelr roles, it became more important to understand quantity for distribution of food, weapons, utensils, and other resources. Eventually, many hunting and gathering groups evolved an agricultural component to their society. The ability to define allotments and distrlbute shares falrly became ever more important with the cultural evolution of socleties.

Six thousand years or more ago, society had evolved to the polnt where human memory could no longer be the sole means of keeping track of commerce and economles. A form of 
permanent record keeping had to be developed. Necessity became the mother of Invention. Someone in Mesapotomia reallzed that when wet clay was marked and allowed to dry, permanent marks remained. Through a necessity, readlly available appropriate materials and someone developing a set of symbols, our ancestors invented writing. The early evolution of wrltten language was a combining and intertwining of tool and concept whlch has continued through to the present.

Our ancestor's early records were accounts and $l$ ists used to register economic and administrative activities (Boorstin, 1983; Kust 1981). Oxenham (1980) writes: "In sum, the comblned pressures of commerce, technology, government, politics, rellgion and culture have created needs, rewards and demands for 11 teracy." From this beginning, the new concept of $1 \mathrm{iteracy}$ and related technology continued to evolve. Those who became literate in written language and related tools discovered new concepts and invented new uses. Now that there was a medium for malntaining permanent records, literate individuals realized that these records could be stored for future use and sent to others far away. If sending records long distances, why not include a message? As the use of 11 teracy became more sophisticated and generallzed to a soclety, changes in related tools took place. 
The next major change in literacy tool technology occurred in Egypt with the development and use of the papyrus reed. The resulting scroll produced from papyrus was much easier to transport short or long distances. Storage also became easier. Egyptlans and others could get more information on a scroll than they could on clay. Also, scralls didn't break when dropped. However, the papyrus scroll did have its draw backs. Papyrus was brittle and could easily be damaged if handled a great deal. Since print literacy was in scroll form, it was not easy to access references.

Assoclated with the evolution of written language is the concept of written historical records. It became possible to record events in a print form to be saved forever. With time, this aspect of literacy replaced the need for extensive memories and the tradition of oral story telling. From the author's perspective, print ilteracy provlded a view of what had transpirad. Stubbs (1980) writes:

The baslc function of a written language, on which other functions logically depend, is what we could call the recording or storage function, and hence the transmission function. Writing provldes a way of recording language whlch is at once accurate, permanent to all intents and purposes with no limltation on time, and transportable, with no limit on distance. (p. 102)

As our ancestors developed parchment, changes continued to follow in the use and expansion of print literacy. Individual sheets of parchment were created and it was 
eventually discovered that these could be sewn together creating a book. Whereas a scroll allowed writing on one surface, it was discovered tha' parchment could be wrltten on the front and back. In addition, it was found that leafing through a book for a reference was much easler and generally quicker than with a scroll. Though the writing material changed, supporting new ways of thinklng, the writing Implement stayed the same. Reed pens continued to be the common writing tool.

When the quill pen was originally developed in Europe durling the sixth century, it was used on parchment. Paper, for writing, would not be available in Europe for another eight hundred years. Those using a qulll found that they could wrlte for longer periods of time since this pen held more ink. Writers also found it necessary to use a small knife in order to sharpen their qulll pen points from time to time. Hence the development of the "pen knife." Though the quill pen has not been a common writing implement for almost two hundred years, a small pocket knife ls still commonly referred to as a "pen knife."

As pen technology has grown so has the number and ease of their distribution. When the fountaln pen was invented it offered writers greater production capabilitles. No longer did a wrlter have to continually dip the pen in an ink well. The steel point made the "pen knife" obsolete. Pens now lasted longer, and as an aspect to the Industrlal Revolution, 
companies developed mass production techniques that were able to satlsfy an ever expanding market demand. Today, ball point and felt tip pens have almost eliminated the threat of running out of ink. Whereas in the past the reed, quill and fountain pens had the capacity to be refilled, most of today's writing implements do not have such a characteristic. These latest editions of pen evolution are components of the throw-away society and therefore are disposed of after use.

Along with the rapld development of pen technology durling the Industrial Revolution, paper production increased dramatlcally as a result of innovative technlques and related machines. A variety of papers became common and available to a widening literate population. Prlor to the Innovation and expansion of paper production, paper was considered an expensive commodity. Individual pieces of paper were used over and over agaln. Once the production of paper became mechanized and paper became Inexpensive, It was used extensively in schools, offices, packagling and throughout Western cultures. Paper has reached the same level of evolutionary development as that of pen technology. We presently live in the print litter era, throwing away both wrltten language documents, junk mall, and Implements for creating them, pens, penclls, and printer rlbbons.

However, earlier in the evolution of written language, the use of paper in Europe allowed for the Invention and refinement of printing. Once Gutenberg perfected the 
technology of printing, a new profession evolved. Thls new profession went beyond the realm of simply printing text. Elsenstein (1985) wrltes: "... new functions performed by early printers, not just as businessmen but also as editors, translators, lexicographers, and cultural impressarios." Print shops became common sights in towns and citles of all sizes. During these centuries following Gutenberg and before the Industrial Revolution, printing was thought of as an art form. This was no doubt an outgrowth of scribes using pens and their writing of manuscripts. Printers took pride in their artistlc accomplishments with type and press.

As print technology spread throughout the West, no longer was Latin the only print literacy language. Vernacular languages began to be accepted. Whereas Latin had been the unlversal language of intellectuals and used for formal education, eventually provinclal languages became accepted by the Ilterate and educated of society. Dating from Roman times, manuscrlpts were usually copied and or written in Latin. Beginning in the second half of the 15 th century, printers began to use the vernacular of the area in whlch they lived.

Other changes slowly came about as people began to work with the technology of printing. It took more than a hundred years after Gutenberg before pagination became standard. Even then, numberling was often incorrect. The technology of printing has continued to evolve to the present where books 
commonly Include a title page, table of contents, numbered pages and an index (Boorstin, 1983). These various innovations helped to make referencing much easier. Individuals can now find quates, compare them from book to book, or use them in other ways. As Plato recounts Socrates dialogue with Phaedrus 2,000 years before Gutenberg, Socrates warns of the loss of memory due to the new technology of writing. Now with the profusion of books and easier referencing, people no longer have to remember large amounts of information.

Manuscript books had provided access to only a few people and couldn't provide a universal print form. Actual handwriting of scribes and authors varied and the use of letter forms often varied from region to region. Though various print fonts have been developed during the past 500 years, today in our varlous written languages there appears to be a baslc shape to each individual letter across these fonts. Today's standard letter shapes allow literate individuals easy access to knowledge through reading.

Once typewrlters became standardized with thelr keyboard and fonts, this writing implement allowed indlvidual's to more easlly communlcate without concern for correct handwriting. As with the printing press, this tool provided a universal print form. In addition, for the indluidual writer or copler of others' work, the typewriter allowed people to wrlte faster and produce more than any earller 
Indlvidually-controlled technology. Simllar to the print letter standardization, typewriter products also allow easy readability.

The latest tool of the print literacy evolution, computers, appears to be a combining of many earlier technologies. The QWERTY keyboard standard of the typewriter is presently the norm for computers. The basic letter form as I now write with a ward processor and look at the microcomputer screen looks the same as if I were reading a book or typing with a typewrlter. The hard copy standard letter shape of this or other electronic text, once tractor paper is removed and accordian paper is separated into indlvidual pages, appears the same as printed or typed text.

Each new change in literacy tool evolution incorporates a new inherently related cognitlon. Although there is a new intrinsic cognition with each advance in literacy tool evolution, as socleties begin to incorporate the new technology they attempt to use it from the perspective of their previous literacy tools. Inltially, printers following the technological inventions of Gutenberg, printed large books similar in slze to manuscript books produced in scriptoriums. With time, printers were able to print books In small paper back editlons which fit into one's pocket. It took hundreds of years for this concept to evolve and then societles to accept it both physlcally and cognitively. Simllar cognitive processing continues with tools of the 
Information Age. There are many new literacy considerations in the present world of microcomputers. No longer are erasers or white out necessary for correcting text. This technology allows one to easily move text about within one text file or to new or old files. No longer does a writer leave a text space, spaces are now an act of textual input. It's easy to replace, copy and delete text to name just a few literacy functions which are different with this new technology. In addition, the concept of reference is changing. It is easler to find speclfic words, phrases, or thoughts within an electronic text than in a printed book which itself was an improvement over a manuscript book which was an Improvement over a scroll.

Since prehistory, the production of print literacy has been a private act. Although historically, reading has been a public act at time, (e.g. oral reading in local taverns) wrlting has generally been a private act. In many cultures there exists a certain soclal inhlbition of not looking over someone's shoulder at what is being written. Generally, compositions become public once they are printed or posted. Even when made public, the reading component of print literacy is private unless a reader Intentionally shares the print orally with others. Now, with the proliferation and universality of televisions and video monitors throughout western culture, when writers use a mlcrocomputer thelr work becomes public. Looking at video screens has become a 
natural component of our culture whether in a local arcade, boutique, school or home. People have become so familiar with looking at video screens that they will naturally look and often respond to what they see.

It is evident that literacy has changed with new forms of literacy technology. Prior to the invention of paper, scribes were few, and clay tablets and papyrus scrolls were not easily transported. During the Nineteenth Century pencils and pens were refined, and became more widely distributed and useful writing implements. The typewrlter continued to expand our ablitities to produce literate communication in a written format. Today there are many who feel that the invention of computers and their use in communication technologies may have an impact upon our soclety simllar to that whlch the printing press had on the world of our ancestors 500 years ago (Evans, 1979; Gallagher, 1985; Papert, 1980; Toffler, 19802.

\section{LANGUAGE AND COGNITIVE DEVELOPMENT}

Communication, whether oral or written, is a function of an individual's cognltive processes. Debate and discussion have occurred through the years relatlve to the relationship of language and cognition. This section provides a glimpse at some of the important consideratlons concerning language and cognitive development as they relate to literacy. 
We have for years acknowlecged that a child's language evolution is a natural aspect of human growth and development. Unless a chlld has some biological or psychological defect, it can be assumed that language will be acquired. Speech and language acquisition in children is a natural process (Allen, 1976; Baghban, 1984; Stern in Vygotsky, 1962; Vygotsky, 1978). It is a function of their cognitive processes related to interactions with their environment. Children follow a general path in their acquisltion of language (Ferreiro, 1982; Gesell et al..' 19402.

An aspect of the interrelationship of language and cognltion is the nature vs. nurture debate whlch has continued for years (Vygotsky, 1962). Thls debate specifically questlons whether cognitive and language development are biologically determined, due to genetics, or influenced sociologlcally, a result of the environment in which one matures. Howard Gardner (in Plattelli-Palmarini, 1980) writes:

At issue ... whether human lingusitic capacities can in any interesting sense be considered a product of generally 'constructed' intellectual development (as Plaget contended), or whether they are a highly speclallzed part of human genetic Inherltance, largely separate from other human faculties and more plausibly vlewed as a kind of innate knowledge that has only to unfold (as Chomsky insisted). (p. XXVII) 
I approach thls study from the perspective that both biological and soclological elements are aspects of normal linguistic and intellectual growth and development.

There are numerous rules and conventions to any 1 anguage and particularly the English language (Burllng, 1976; Stubbs, 1980). In addition to being unaware of these rules and conventlons, young children also are not aware of individual speech parts, i.e., sentences, words, and letters (stubbs, 1980). Children, cognitively functioning in the pre-operational stage of development, approximately 3 - 5 years old, are unable to visualize parts and the whole simultaneously (Huber, 1985). Even children who enter school at age flve often are not aware of the Indlvidual components to their speech (Donaldson, 1978). Children, alone as well as when interacting with others, put forth an intense effort attempting to reinvent, generate, and discover language rules and conventions. (Inhelder in Piattell1-Palmarin1, 1980). In addition to psychological processes, chlldren's language development is partially a soclal phenomenon.

Language development in young chlldren is promoted through play and actlve involvement in soclal Institutions and situations. It is important for the intellectual development of children that they interact with their surrounding environments. Through such interaction, chlldren psychologically develop an understandlng of specific objects and concepts. During their chlldhood, chlldren 
psychologically follow a process of actively transitioning from one cognitlve stage to another. The young child has opportunities to play with and manlpulate items within his/her environment during his/her sensor lmotor stage (Franklin, 1973). During the preoperational stage, the normal young child begins to realize the abstractness of his/her toys. A child two or older accepts that a toy out of sight can still exist. In just a few years, the child psychologically evolving through the concrete operations stage of cognitive abilitles wlll be able to use abstract symbols to represent an object or concept. An example of a child's growth from concrete experiences to abstract representation can be observed when a chlld draws a plcture of a cat. The picture consists of a few squiggly round lines, a couple of stralght lines depicting wiskers and two accompanying clrcles with dots. This young artist may then verbally label the "cat picture."

It is important psychologically to have an understanding of concepts and objects in order to learn a language (Tolstoy in Vygatsky, 1962). Fodor (Plattelli-Palmarinl, 1980) has stated: "Clearly, you can't learn a word that expresses a concept that you don't have" (p. 173). Fodor follows in summary: "Nobody would learn the word 'cat' unless he knows what a cat is" (p. 173).

This understanding of "cat-ness" or "word-ness" leads us to Plaget's conslderation of language belng "... a partlcular 
case of semiotic function" (Plattelli-Palmarini, 1980, p. 163). It follows that words in a language, oral or written, are slgns that represent different objects, concepts, and ideas. In addition, certain signs have multiple meanings and are dependent upon the context in which they are used. In sumnary, the language and cognition relationshlp can be viewed as the soclo-psycholingulstic process. The individual interacts socially with his/her environment and psychologically (cognitively) generates language to function within the soclal environment. Harste, Woodward, and Burke (1984) explain: "By process we mean the cognitive stances language users assume, and the strategles or cognitive actlvitles language users engage in, during a literacy event. We label this process "soclo-psycholinguist 1 " because we see language as sociologlcally rooted, and language learning as understandable only when viewed within its social context. Psychollnguistic processes have their genesis in the literacy demonstratlons made available to language learners as they encounter members of their interpretive community engaged in the psychological and soclological actions associated with literacy" (p. 49)

Piaget observed that children actively reinvent through dlscovery (Donaldson, 1978). Chlldren cognltively attempt to understand their world through Invention of hypothesis and associative Implementation (Ferreiro, 1982; Kaml1, 1985; Wellman, 1982). Such hypothesis-inventing requires the 
understanding of objects, concepts, and ideas, often along with the corresponding words, In order to place these into some cognitive form, schemas. Through their discoverles and language play, children assimilate their new inventions into schemas and cognitive understanding (Ferreiro, 1984). Ferreiro and Taberosky (1982) write:

Evidence ... suggests that language learning does not proceed through the acquisition of isolated elements which gradualiy join together, but rather through the formation of systems where the value of the parts continually redefines itself in function with the changes in the whole system. In addition, this evidence also demonstrates the existence of what we could call 'constructive errors,' that is, responses differing from correct responses but, far from impeding emergence of the latter, permitting subsequent development. (p. 8-9)

The process of language development that children experience occurs in the natural surroundlngs of their family and community (Leichter, 1984; Schachter, 1982; Smith, 1984). Heal thy young children hear and experlence those around them converse, chat, and sing, often while enjoying cuddles and coos from loving parents. In natural settings, parents Interpret, reiterate, and model speech and oral language. Children listen, speak, actlvely interpret, hypothesize, and reinvent language as they attempt to be an active member in their social environment. Through thls process their own linguistic abilities evolve and develop (Donaldson, 1978; Holdaway, 1979, 1984). The prlority in language development is not immediate correct pronunciation and usage, but the continual generating and refining of one's vernacular 
language (Eerreiro, 1982; Holdaway, 1979, 1984). Young children have the opportunity to interact with their parents and others in activitles assoclated with this process which often promotes additional contact, environmental awareness, and further affection (Vygotsky, 1962; Holdaway, 1979, 1984). Harste, et al. (1984) write:

Language convention, like language, is socially invented in a supportive environment which makes such discoveries available; it is not an heirloom like a grandfather's clock which is passed along from generation to generation, but rather, more like a civilization whose heritage is passed along by those immersed in it. (p. 30 )

Language-learning skills are not isolated from mental growth (Donaldson, 1978). Vygotsky (1962) states: "The child's intellectual growth is contingent on his mastering the social means of thought, that is, language" (p. 51). Children require a varlety of experiences in order to develop concepts which they then can assign a learned language symbol to represent. Even though thought and language are different, the Interrelatedness of language and cognition are extensive (Vygotsky, 1962). Chomsky (Piattelli-Palmarini, 1980) states:

I take it for granted that thinking is a domaln that is quite different from language, even though language is used for the expression of thought, and for a good deal of thinking we really need the mediation of language. ( $p$. 173)

The lssue of intelligence in relationship to soclo-psycholingulstles gained further clarlflcation in the late 1970's during the Piagetian Constructivism and Chomsklan 
Innatism debate. Piaget stated: "In other words, and here I totally agree with Chomsky, language is a product of intelligence rather than intelligence being a product of language" (Piattelli-Palmarini, 1980, p. 167). These scholars attempt to make it clearly understood that language produced through the soclo-psycholingulstic process is a product of one's intelligence.

Related to language and intelligence, some scholars feel that cognitive development may be greatly enhanced by becoming literate (0lson, 1985; Stubbs, 1980; Vygotsky; 1962). Oxenhan (1980) writes: "It is not Implausible to suppose then that the association between 1 iteracy and Intellectual and scientiflc advance is close" (p. 60). Barbara Inhelder (Piattelli-Palmarini, 1980) has wrltten:

The more we progress in our knowledge of the language development of the child, the more we become aware of the intense activity he puts forth to discover the rules and functions of his own lingulstic capacity. It is legitimate to think that this activity of linguistic discovery, in its turn, has a repercussion on the development of $h$ is knowledge in other domalns. (p. 134)

Further consideration on this concept comes from Chomsky (Plattelli-Palmarini, 1980) as he writes:

.... It is entirely concelvable that some complex structures just aren't developed by a large number of people, perhaps because the degree of stimulation in their external environment isn't sufficient for them to develop. ( $p$. 176)

There are scholars who question whether many individuals reached the cognitive stage of formal operations prlor to the 
advent of earlier technologies (Huber, 1985; Stubbs, 1980 ). Historically, we are aware of the lack of literacy among the majority of our ancestors prior to the invention of the printing press and wide distribution of printed material. The issue of universal literacy is only 3 or 4 generations old (Oxenham, 1980). There are those who theorize that with the advent of new technologies, cognition and Iiteracy is enhanced (Holdaway, 1984; Stubbs, 1980). Related to this, Dalute (1985) writes:

Although it is useful to consider writing in the mind separately from writing with the hand to understand the dimensions and complexity of each activity, the writing instrument itself can affect the cognitive process. The instrument can stifle the mental dynamism of writing, enhance it, or make no difference at all. (p. 6б)

Seymour Papert (1980) of MIT shares his thoughts about the creation of a completely new learning environment based on the latest tools of the Information Age in hls book Mindstorms:

I belleve that certain uses of very powerful computational technology and computational ideas can provide chlldren with new possibilitles for learning, thinkling, and growing emotionally as well as cognitively. (p. 17)

Further, Papert feels that chlldren will begin thinking about thinking, learning about learning and become eplstemologists (Papert, 1980, c. 7). We may be experiencling the beginning of another great leap in human language and cognition. Scollon and Scollon (1985) write: 


\begin{abstract}
Our preliminary work with computer conferencing has led us to think that the current rapidly expanding use of computers in communication is bringing about change in the possibilities of discourse, possibilities not seen in the world at least since the introduction of widespread printing. (p. 135)
\end{abstract}

Developmental psychologists, linguists, and others acknowledge that language is a natural component to human growth and development which evolves through a soclo-psycholingulstic process. Children develop an awareness of language through its use. As children grow, their oral and written language evolves through their discovery, hypothesizlng, and generating. No matter where one is in the nature vs. nurture debate, there appears to be agreement about an interrelationship to language and cognltion. There also appears to be an accepted theory as McLuhan (1962) in "The Gutenberg Galaxy" writes that the socio-psycholinguistic process of human language evolution is influenced by communication technologles.

\title{
LITERACY
}

Related to language is 11 teracy which in a print literate soclety is a natural process and component of human growth and development. Smith (1984) has written, "All children are born llliterate" (p. 143). Literacy is a composite of skllls which we continue to develop throughout our lives. This section delves into recent research and 
writings about literacy. I begin with some thoughts concerning a world perception of 1 iteracy.

Many people throughout the Engl ish speaking world have theorized for years that reading is synonymous with 1 iteracy. In American as well as British schools, reading has, and generally continues to be, the important academic subject. Due to global British colonialization and Amerlcan influence, this notion has been transmitted to societies throughout the world. When national and international governments and organizations refer to literacy rates, they express numbers signifying the percentage of people who have developed some level of reading skill. Throughout the world, there appear to be two standards of 11 teracy. Stubbs (1980) wrltes: "... one referring to the ability to read and write, one referring to wldeness of education, and both these uses are relatlve to cultural expectations" (p. 14).

Literacy is a relative term, and the expression "cultural expectations" allows for yet another division: literacy end functional literacy. Functional literacy allows an individual to get along on a daily basis within his/her environment. However, such limlted literary skllls are not used for learning or entertainment. Functional literacy skills exhibited by an individual would consist of the abllity to read blllboards, signs, simple notes, and write his/her slgnature. Beyond this simple abllity to function in one's immediate environment, is literacy: the ability to use 
these skllis for intellectual stimulation and entertainment, e.g. reading, writing, theatre, study, etc. (Stubbs, 1980).

Literacy has more components and is a much more encompassing concept than simply reading. First one should consider it as a process and not a magical moment in which suddenly one becomes literate (Ferreiro \& Teberosky, 1982; Goodman, 1984; Harste, et al., 1984). As Vygotsky (1978) writes of learning about signs, "They are not invented or discovered by the child in the form of a sudden insight or llghtning-quick guess (the so-called 'aha' reaction)" (p. 45). Secondly, in more recent research, literacy has been observed to encompass not only the skills of reading and writing, but also those of speaking and listening (Baghban, 1984; Bissex, 1980; Holdaway, 1984; Taylor, 1983). All of these skills are interrelated in the process of becoming l iterate CHoldaway, 1979, 1984; Stubbs, 1980; Vygotsky, 1962). These two aspects of 11 teracy are summarlzed by this quote from Harste, et al. (1984):

$$
\begin{aligned}
& \text { Literacy is never a glorifled state one } \\
& \text { enters, but involves constant orchestration and } \\
& \text { reorchestration of the sign complexes of literacy } \\
& \text { as contexts change and evolve. (p. 185) } \\
& \text { Researchers in various disciplines have published }
\end{aligned}
$$
findlings that literacy begins long before chlldren begin school (Allen, 1975; Baghban, 1984; Blssex, 1980; Goodman, 1984; Harste, et al. (1984); Holdaway, 1979, 1984; Sheridan, 1986; Taylor, 1982, 1983; Vygotsky, 1962). The development 
of 1 iteracy begins prior to birth as a fetus listens for sounds from their environment. This early development continues through the foundation years with the result that children have a good understanding of spoken language by the time they enter school (Calkins, 1985; Clark, 1984; Goodman, 1984; Hayes \& Plaskon, 1982; Stubbs, 1980).

Young children's knowledge of language is not limited to their ability to ask for assistance and make needs known and understood. It also encompasses a large vocabulary and the ability to be articulate about their lives and experiences. In addltion, many chlldren enter school with an understanding of symbol relationships (Goodman, 1984). They are aware that the Golden Arches means a place to eat and that the large, M-shaped sign has the connotation of McDonald's, hamburgers and French frles (Baghban, 1984).

The use and development of literacy is an extremely Important component to family 11 fe CAnderson \& Stokes, 1984; Butler 1975, Clark, 1984; Heath \& Thomas, 1984; Leichter, 1984; Taylor 1982, 1983; Teale, 1984). The ingredlents to this component of family life are not broken down into analytical steps which chlldren learn under the supervision and instruction of mother, dad, and siblings. The approach to literacy in a famlly is that of whole language. All components to 11 teracy, talking, listening, writing and reading, are integrated, generated, modeled and shared by family members. Taylor (1983) refers to this developmental 
process in family settings: "It was a whole language process in which listening, talking, reading, and writing grew as interrelated forms of a communicative system" (p. 76).

We have assumed that print literacy is to be learned through formal instruction (Baghban, 1984; DeFord \& Harste, 1982; Taylor, 1983). Children spend the first four or five years of their llves in a supportive, accepting and loving environment of the home and greater community where they learn through play, imitation, trial-and-error and by what Plaget coined, "reinvention through discovery." This is too often followed by over-crowded and Impersonal experlences at school. Typically, as children begin school, there is a sudden attltude shift: print 11 teracy development can only occur through direct instruction by an adult (Baghban, 1984; Holdaway, 1984; Smith, 1984). Leslie Hart (1986) has written: "If we observe children, we see that they learn magnlficently and with joy--until they go to school and encounter aggressive teachlng" (p. 48). Also, an attitude change often occurs within famllies as chlldren begin school. Denny Taylor (1983) reports:

... the data also indicate that 'shifts' occurred in the parents' approaches to the transmission of 1 iteracy styles and values, and these shifts coinclded with the child's beginning to learn to read and write in school. (p. 20)

Yet the earlier literacy skills of oral language, listening, and early symbol ldentiflcation have occurred in a relaxed, supportive, and loving home environment. Lucy McCormick 
Calkins (1985) makes reference to the type of setting where print literacy can flourish:

Most language--learning occurs through self-generated, functional, hol istic activities; through approximation and error; through bonded relationships with people who are joyfully IIterate. (p. 235)

No doubt, educational philosophles are often a reflection of our human history and a result of social and political considerations of the time. McLuhan (1962) writes: ... from the invention of the alphabet there has been a continuous drive in the Western world toward the separation of the senses, of functions, of operations, of states emotional and political, as well as of tasks--a fragmentation ... (p. 42)

In contrast to Hart's statement, quoted in the previous paragraph, many early chlldhood educators have always fostered a school atmosphere supporting a holistlc approach to the development of literacy. Now, during the eighth decade of the 20th century, similar holistic educational atmospheres are becoming more common in American elementary schools.

Scholars in education and psychology recognlze that play is children's work. We reallze and accept that children learn through the games and actlvites they use in their play (Jacob, 1984: Morell 1985). Vygotsky asserts that chlldren will often play beyond thelr chronological ability cVygotsky 1978). In Becoming a Nation of Readers (1985), It has been reported that chlldren read at a hlgher level when reading about a subject which ls of interest to them. Chlldren in 
these sltuations are internally motivated and willing to take risks. They are often self-corrective along with their rlsk taking, and, as a result, accelerate their own learning (Holdaway 1984). Further, Harste et al. (1984), focuses upon the lmportance of risk in language learning:

Because language is an open slgn system, rlsk is necessarlly a central feature of the process involved in its use. Without risk there can be no discovery of the generative potentials of literacy. (p.132)

Literacy is a developmental growth process which cantinues to evolve throughout our entire lives (Baghban, 1984; DeFord \& Harste, 1982; Smith, 1984). Holdaway (1979) writes:

Developmental learning is highly indlvidual and non-competitive; it is short on teaching and long on learning: it is self-regulated rather than adult-regulated: it goes hand in hand with the fulfillment of real i ife purposes: it emulates the behaviour of people who model the skill in natural use. (p. 14)

As prevlously mentloned, there are four major components to llteracy: speaking, listening, writing and reading (Holdaway, 1979; Stubbs, 1980). These components are Integrated and Interrelated within our cultural environment. In natural settings, the development of literacy is viewed as a process and achleved in a hollstic fashlon.

In recent decades, there has been a change in the manner scholars view literacy. The abllity to use oral and written communication is a holistic function of cognition and growth through the Interactlons one has with the soclal institutions 
of soclety, the socio-psycholinguistic process. Many of the growth functions acknowledged in language and cognitive development are found in the evolution of literacy--an individual's accomodation and assimilation into schema and the influence of famlly and community. Smith (1984) has written:

... I iteracy is both Individual and social--individual because the impetus must come from the child, but social because literate others must provide the demonstrations that engage the child as a literate member of society. Children do not become literate in a vacuum. On the other hand, chlldren cannot anticlpate society's uses for literacy (and perhaps would not become literate if they could). Literacy develops because the child sees what reading and writing can do, and because it is relevant to the child's own creative and constructive purposes (p. 151).

\section{WRITING RESEARCH}

There are a number of components and various elements involved in the evolution and development of literacy. One of the most neglected components to be researched is writing. Burrows, Jackson, and Saunders (1984) have written: "Compared to the amount of research in chlldren's reading, the history of research in children's writing is a very scanty account" (p. 174). Considering wrlting research related to past cultures, Michael Stubbs (1980) has wrltten:

$$
\text { ... the forms and functions of written }
$$

language have been neglected by both lingulstics and by soclology and anthropology, and that of ten only rudimentary, common-sense observations are avallable (p. 16). 
A perspective on recent research is shared by Graves (1984) who wrote near the beginning of the 1980's:

Only 156 studies of writing in the elementary grades, or an average of six annually, have been done in the United States in the last twenty-five years. ... These $f$ igures came at a time in American education when most school money was spent on developing children's reading skills. For every $\$ 3000$ spent on children's ablilty to recelve information $\$ 1.00$ was spent on their power to send it in writing. (p.93)

This section focuses on aspects of writing research which appear Important to the early development of print literacy. We have made an adult assumption through the years that reading precedes writing (Holdaway, 1984; Oxenham, 1980 ). Related to this assumption, in a print-literate world, functional literacy refers primarlly to reading abillty while writing has evolved as a secondary skill. Until the past flfteen years, there has been 1 ittle writing research in the grade school classroom (Calkins, 1985, 1986; Clay, 1975; Graves, 1983). Calkins (1985) wrltes: "Dver the past flfteen years there have been, for the flrst $t$ lme, major studles on how chlldren change as writers" (p. 26).

Research focused on chlldren's writing has primarily been conducted by two academic disciplines, psychology and education. Scholars in psychology have conducted research in attempts to discover connections between writing and cognltion. Educators have sought additional inslght into the teaching of writing. In the early part of this century, Vygotsky (1962) and his assoclates found that there was 
little writing going on in schools. This deflclency in writing has generally continued through the rest of this century, at least to the $1980^{\prime} \mathrm{s}$. Lack of opportunity to write in schools is no doubt a factor in the small amount of research that has been conducted in this field of study. Early during the 20 th century, many psychologists studied oral language and its complex relationshlp with cognition. In addition to such studies, Luria and Vygotsky and hls colleagues Investlgated wrltten language. Vygotsky (1962, 1978) and his colleagues found that written speech differs from oral speech both in structure and mode of functioning. They also determined that even a minimal ability of writing required a hlgh level of abstractness. Finally, they concluded that it was the abstractness of written language whlch caused chlldren to have difflculty with writing, not mechanlcal obstacles or underdevelopment of small muscles.

Within educational research, there have been primarily two approaches to the Investlgation of writing. Until the late $1960 \mathrm{~s}$, the mode to investigate writing was through evaluation and examination of writers' products. In 1969 Janet Emig introduced a new form of wrlting Investigation through her case study "Composlng Processes of Twelth Grade Students." This new approach took into consideration the process of writing. Enig's research was soon followed by the publication of Donald Graves' dissertation study and 
findings. By the mid-1970s, Graves, along with his colleagues, was conducting extensive research dealing with the writing process of elementary school children. This new form of investigation considered the final product but focused more on its evolution. Observation centered on the writing process itself, what the writer did as the composition took form, and environmental factors related to composing. Investigators were now looking at many of the variables one finds in a wrlting environment. The research of these investigators along with that of Luria and Vygotsky provides us wlth a baseline for the study of the wrlting process.

Of interest is that during the $1920^{\prime}$, Vygotsky (1978) had written about the importance of observing process in research:

In summary, then, the alm of psychological analysls and 1 ts essential factors are as follows: (1) process analysis as opposed to object analysis; (2) analysis that reveals real, causal or dynamic relatlons as opposed to enumeration of a process's outer features, that is, explanatory, not descriptive, analysis; and ( 3 ) developmental analysis that returns to the source and reconstructs all the polnts in the development of a given structure. (p. 65)

During the $1980^{\prime}$ s Harste et al. (1984) follow a similar direction: "Based on our experience, we advocate use of open-ended, real language situations in which the child, or language user, becomes the research and curricular informant" (p. 51 ). 
The seeds of writing are there early in the development and growth of children. Over fifty years ago Vygotsky (1978) wrote:

The gesture is the inltial visual sign that contains the child's future writing as an acorn contains a fut re oak. Gestures, it has been correctly sald, are writing in air, and written signs frequently are simply gestures that have been fixed. (p. 107)

These early seeds of writing are not only seen in gestures, but also in play, speech, and drawing (Atkins, 1984). It is obvious that writing, along with the other components of literacy, is a natural part of human growth and development. Baghban (1984) shares:

We continue to learn during our entire lives through speaking and listening and, in a print laden society, through reading and writing. We grow and change, and our language grows and changes with us. Iiving is itself a process. Thus, language as a means for survival, growth, and pleasure is likewise a process. (p. 3)

Writing is holistically intertwined with the other components of 11 teracy and influenced by one's enviconment. This process begins when children are very young (Atkins, 1984; Calkins, 1986; Graves, 1983; Froese, 1978; Holdaway. 1979, 1984; Wellman, 1982). Calkins (1985) writes: "... current research has shown that youngsters are writing long before they come to school" (p. 26). Harste et al. (1984) state in reference to their research:

These data support the notion that young chlldren are written language users and learners long before they recelve formal instruction and 
that they actively attend to written language; in short, there is literacy before schooling. (p. 82)

Luria (1978) held similar conclusions years ago:

The moment a child begins to write his first school exercises in his notebook is not actually the first stage in the development of writing. The orlgins of thls process go far back into the prehistory of the development of the higher forms of a chlld's behavior: we can even say that when a child enters school he has already acquired a wealth of skllis and abilitles that will enable him to learn to write within a relatively short time. (p. 65)

To young chlldren, writing is initially approached from a hollstlc perspective (Atkins, 1984; Clay, 1975). A few scribbles on a paper may mean an entire book, story, or long letter to grandma (DeFord \& Harste 1982). To young children the accomplishment of writing their own name has more meaning and value to them than just the visual sign. They make a holistlc assumption of what their name means. Young children interpret this symbol to represent all their personal characteristics, "My Sign," "My Name". This is a symbol or sign of "me-ness" to a young chlld. As their understanding of language and print literacy matures, chlldren move along a continuum of development, first representing whole thoughts through a mark on a plece of paper, later a letter, groups of letters, a few words, phrases, sentences and eventually stories (Clay, 1975; Harste, et al., 1984; Luria, 1978; Wood, 1982).

Logically it follows, and researchers have found, that mechanles is secondary to meaning in importance to young 
chllaren in their writing CCalkins, 1983, 1986; Forester, 1980; Luria, 1978; Milz, 1980). Luria (1978) writes:

One thing seems clear from our analysis of the use of signs and its orlgins in the chlld: it is not understanding that generates the act, but far more the act that gives birth to understanding indeed, the act often far precedes understanding. (p. 113)

This appears to reflect that young children's writing is holistic. As previously written in the language and cognition section, it is difficult for a young child to consider the whole and parts simultaneously. of primary importance for children is to communicate the message. As children's understanding of print literacy grows, they begin to use the sound symbol relationship as defined by our soclety, the English language. Schleffelin and Cochran-Smith (1984) write: "In these (early) literacy events, children's control of the uses of print preceded their control of the mechanical skills of decoding and encoding" (p. 8). Recognizing a child's cognitive stage and related processes are important to an investigator's understanding of a child's growth and the writing process. Chlldren interpret, define, edit and revise at the cognitive stage where they are developmentally. Revision of wrlting may be done abstractly by older students or adults, but young children look at it concretely and may not see where changes should occur (Calkins, 1983; Ferreiro \& Teberosky, 1984) Initially, young children concentrate on the physical aspects 
of wrlting, and as they begln to mature, there is a growth of covert abstract behaviors. An important consideration for young writers is what occurs now, not necessarily what has already transpired.

There are many rules and conventions one must learn in order to write. For a young child there is so little understanding of the system and so many rules and conventions to be learned ( $C l a y, 1975$; Luria, 1978). These rules of order are learned intrinsically--they arise from the Individual's interaction with the environment (Chomsky in Piattelli-Palmarini, 1980), what Harste et al. (1984) refer to as the sacio-psycholinguistic process. As rules and conventions are learned, tested, and generallzed, they allow the wrlter to make changes in his/her work (Templeton, 1980). Generalizations by children are often overdone and may change the perception orlginally intended for a plece. An example of an over generallzation at this transition age is the use of silent $e$. The different meanings of hop and hope can drastically influence the intent of a plece.

Harste et al. (1984), "... the young child is a written language user long before his writing looks representational" (p. 16). Children need only a few letters in order to begin writing (Chomsky, 1971; Graves, 1983). Therefore, spelling, a subskill of composition, is often incorrect. Even though words are often misspelled, children are generally following language rules and conventions as they know them (Hayes \& 
Plaskon, 1982). At other times, some of the misspelling, as well as use of words, may be a result of their play and experimentation with sounds, letters and vocabulary (Clay, 1975; Forester, 1980). Such play and experimentation also occurs with other wrltten language rules and conventions. Moving left to rlght and top to bottom on a page must be learned for writing English. At times, young writers wil! try to reverse a newly learned rule, e.g., wrlte right to left. Even though chlldren are able to begin writing knowing only a few letters, there is continuous and extensive learning required to understand addltional rules and conventions and to experience the writing process.

Investigators often make reference to a child's first year of writing as occurring during grade one, and that it is durling this year one observes chlldren maklng the most progress (Atklns, 1984; Calklns, 1986; Graves, 1983; M1lz, 1980). There is understandably a great deal of change in what we see in children's writing development during the ages of 5,6 , and 7 . Durling these early school years, chlldren begin to see themselves as writers (Calkins, 1985, 1986). Also during this chronologlcal period parents wlll recognize that their child is writing messages and complete thoughts. What we often do not reallze and recognlze is the chlld's understanding of literacy and the covert effort put into such development as a preschooler. After observing her daughter's Elrst three years of life, Marcia Baghban (1984) has written 
of the tremendous literacy growth her daughter made including the understanding of print and symbols. Writing becomes overt durling the early school years. Adults recognize the child's compositions as now being more adult-like as their wrlting beglns to approximate standard English.

Many researchers have come to realize the extensive amount of cognition that occurs as an individual writes (Atkins, 1984; Calkins, 1986; Clay, 1975; Graves, 1983; alson, 1984; Vygotsky, 1962). Vygotsky (1962) has written: "Writing also requires dellberate analytlcal action on the part of the child" (p. 99), while Daiute (1985) states: "Writing is a cognitive process" (p. 52). A writer has a hol istic concept in mind when pen is put to paper or fingers to keyboard. As the author begins, $s /$ he must make decisions and solve problems as to how s/he will communicate with his/her audience. Once the process of writing begins, it becomes a problem solving task (Atklns, 1984; Calkins, 1986; Graves, 1983). Atkins (1984) has written: "Any given piece involves a continuous interplay of many elements-thinking. writing, reading, rethinking, rewriting, rereading, and so forth" (p. 6). Some scholars have written that writing is a tool for helghtening and refining thinklng C Calkins, 1983; 01son, 1984).

Writing allows researchers the opportunity to observe people thlnklng (Calkins, 1983; Dalute, 1985; 0lson, 1984). As authors wrlte, they ask questions of themselves, 
attempting to consider their audience, their intended message and conventions of written language. All of the categories in Bloom's cognltlve domain are used by writers colson, 1984). In particular, the higher processes of cognition are required when writing; analysis, synthesis, and evaluation. These cognitive processes are used as an author writes, reads, rewrites, rereads, and continually repeats these literacy processes again and again.

An outcome of writing and its attendant cognitive processes is learnlng. Graves (1983) writes: "Growth comes when problems are solved by child or adult" (p. 233). As children toil with their compositions, they not only think, but are intrinsically motivated to make decisions about their creations. These experiences and problem solving events evolve into knowledge which can be of use in other writing and literacy activities. Once chlldren experience these problem solving processes, they often share their knowledge with others (Calklns, 1983, 1986; Graves, 1983). Dyson and Genishl (1980) observed beneflts for those who deslre to work around others; a group provides models, assistance, and encouragement.

During the early $1980^{\prime} \mathrm{s}$, Dyson and Genlshl (1982) Investlgated the verbal Interactions assoclated with writing among flrst grade students. Among their findings is the recognition that chlldren have different approaches to writing. Some chlldren tend to work alone, while others 
desire the support of a group. They also observad that all the children listened to their own speech in order to bridge oral and written communication.

Another factor influential to the writing process is content. Investlgators feel that the relevance of writing materia!, the topic, is an important factor in children's composition (Allen, 1976; Donaldson, 1978; Harste, et al., 1984; Vygotsky, 1978). Many investigators have discovered the importance of and promote children choosing the ir own writing topics (Calkins, 1983, 1986; Graves, 1983). Allowing children to choose their own toplcs provides them with the opportunity to decide on something which is of significance to them. If young writers are permitted to choose a topic to write about, the child does not only develop a sense of ownership, but becomes internally motivated to produce a qual ity praduct (Sorensen \& Kerstetter, 1979; Toth, 1982). This allows the educator to cultivate the fertlle interests and inclinations of the child In his/her written work instead of imposing instruction from without (Holdaway, 1984; Vygotsky, 1978).

Related to children choosing their own toplcs is the amount of time children spend writing. In the past, when topics and instruction were imposed, writing did not occur for very long and work on compositions rarely carrled over from one day to another. Where there is an understanding that writing is a developmental process and chlldren are 
al lowed and encouraged to choose topics, investigators have found children spending tremendous amounts of time writing (Calkins, 1983; Graves, 1983). This commitment to writing is found not only during classroom time -- children have been observed spending their own time as well (Calkins, 1983). The tlme spent is on all phases of the writing process and often extends from one day to another on one toplc or composition. It appears that, when allowed and encouraged, children will dedicate a great deal of time and effort to writing.

Although Lurla and Vygotsky's work was published in the West during the last two decades, their work had begun in the $1920^{\prime} \mathrm{s}$. From then until the 1970's, litele writing Investigation had been completed. During the past 15 years, research on writling has moved from a focus on product to an observation of the total print literacy environment including an individual's process of writing. Much of this research, as well as that of Vygotsky's, has included a perspective on the importance of cognltion in the wrlting process. Present research demonstrates that writing is a component of 11 teracy which is a soclo-psycholingulstlc process. We begin as young children to scrlbble and draw with and on what ever materlal is avallable. Reinventing through discovery children generate the rules and conventlons of their native language and contlnue to expand their knowledge and understanding as they become ever more efflclently literate. 
In Clay's (1975) book What Did I Write?, she describes a general sequence of developmental writing behaviors she has observed in young chlldren whose print literacy is evolving. From these developmental sequences, she has deslgned three scales for determining children's early writing progress. of her proposed three scales, one does not apply to this research, "DIRECTIONAL PRINCIPLES," which is a referent to the directions in which children write across paper. Writing direction with a word processor is determined by the software. Figure 2.1 contains two of Clay's scales, LANGUAGE LEVEL AND MESSAGE QUALITY. Each of these scales include short defining statements.

LANGUAGE LEVEL: Record the number of the highest level of linguistic organization used by the chlld.

1. Alphabetic (letters only)

2. Word (any recogni sable word)

3. Word Group (any two word phrase)

4. Sentence (any simple sentence)

5. Punctuated story (of two or more sentences)

6. Paragraphed story (two themes) MESSAGE QUALITY: Record the number below for the best description of the child's sanple.

1 . He has a concept of signs (uses letters, invents letters, uses

2. He has a concept that a message is conveyed (ie he tells you a message but what he has written is not that message).

3. A message is copied, and he knows more or less what that megsage says.

4. Repet Itive, Independent use of sentence patterns like 'here Is a ...'

5. Attempts tó record own I deas, mostly independently.

6. Successful composition

Fiqure 2.1 Two of Marle Clay's (1975) arbitrary rating scales from her book that Did I Write?, subtitled "Beginning Writing Behaviour" (p. 66).

Luria (1978) has also written of stages children experience in their evolutionary development of literacy. He shares: 
Lines and scribbles are replaced by flgures and pictures, and these give way to signs. In this sequence of events lies the entire path of development of writing in both the history of nations and the development of the child. (p. 83)

Using Clay (1975), Luria's (1978), and other scholars'

work I propose that young chlldren move along a developmental writing continuum similar to the one which follows (Graves, 1984; Holdaway, 1979, 1984). Although I present this developmental sequence, I do not envision this as stages which all children must progress through. Instead, I present this as an evolutionary continuum which budding literates experience. My proposed continuum is presented in reference to Harste et al. (1984):

Current yardsticks divert attention away from growth and toward 'developmental stages,' which attempt to calculate growth by marking surface level features of conventional form. Such a focus draws our attention away from the universals of wrltten language literacy, which operate across language users at all ages and simply express themselves in a varlety of alternatlve forms. It limits our thinking about literacy. Literacy becomes a step-by-step progression of control, not a vehicle for exploring and expanding our world. (p. 12) 
1. Scribbles

2. Scribbles \& Plctures

3. Copy

4. Name

name, alphabet, numbers, words)

5. Word

(write own name)

(inventive recognizable word)

initially wi thout vowels

6. Word Group

(two or more word phrase)

7. Sentence

(a simple sentence)

8. Story

(two or more sentences

9. Punctuated Story

(story with appropriate punctuation)

10. Paragraphed Story

(story with more than one theme)

Figure 2.2 Writing behaviors of chlldren in a print-laden society. This author's interpretation based upon readings and observation.

It has been suggested by previous researchers that with

the use of pencils, pens, crayons, paper, etc. Swriting

tools) children explore with their writing implements and

progress through stages of writing development. Now with the

advent of electronic technology and its use by children

developing their literacy, is there a common print literacy

developmental sequence chlldren experlence as they write with

a word processor and how does this relate to earlier research

of older writing technologles? 
COMPUTER RESEARCH RELATED TO WRITING

Beginning in the late $1970^{\prime} \mathrm{s}$, microcomputers burst into the consciousness of modern men and women. Ever since, the microcomputer has been touted as a resource for everything and a machine no one should go without. Educators, primarily from the fields of science and math, began to implement the use of these machines in thelr curriculum. Following microcomputer use in math and the natural sciences, other educators have slowly begun to employ this tool in various areas of the curriculum including language arts and the literacy component, writing. Scholars have written glowingly of the possibilities for this new writing machine (Bradley, 1982; Christensen, 1983; Daiute, 1983, 1985; Eagan, 1984; Fisher, 1983; Halpern, 1984; 0lds, 1985; Papert, 1980; J. Smith, 1983). Donald Graves (Green, 1984) has stated: "I think marvelous things can be done with the computer as a word processor..." (p. 21), while Don Holdaway (1984) shares:

... the mini-computer and word-processor, because they carry the competence to store and edit, represent a breakthrough for composition, and young children seem to have remarkable facility in learning to handle computers. (p. 28)

Although there are many enthuslastic supporters, very little investigation of the word processing tool and early writing has occurred (Kurth, 1984; Miller, 1984; Watt, 1983). Now in the mid $1980^{\prime} \mathrm{s}$, scholars and researchers are beginning to question, investigate, and predict the impact of 
microcomputers on the writing process (Daiute, 1985; Green, 1984; Holdaway, 1984; Zinsser, 1983). This section is a literature review of computers as they relate to young children's writing.

Information about the history and development of computers and other writing implements is avallable elsewhere (Alessi \& Trollip, 1985; Boorstin, 1983; Oxenham, 1980). Of interest, is that as humans have continued to generate more information, early computers were constructed to store and manipulate varlous types of records and large amounts of data. Such use is similar to the impetus of our ancestors' first use of writing, record keeping. In reference to our ancestors' development of writing, Kust (1981) states:

It is thought that this complex economic organization begot writing. Records of production and revenues, property and water rights had to be kept. Commerce and trade in the cities called for written contracts. In fact, most of the oldest tablets are concerned with economic matters. ( $p$. 471)

There are varlous types of writing software avallable (Anderson-Inman, 1986; Gallagher, 1985; Humes, 1982; Marcus, 1983; Shostak, 1983). Some programs have been designed for large mainframe computers, whlle versions of these or new ones have been deslgned for microcomputers. Miller (1985), whlle conducting a survey of the early 1980's literature, used four categorles to classlfy the teaching of writing with computers: (1) computer-prompted Idea generation, (2) text analysis, (3) computer-assisted instruction, and (4) word 
processing (c. 2). None of these categories have received an abundance of investigation.

In the category of word processing there are four basic subcategorles: (1) text editors, (2) batch-formatting programs, (3) online formatters and advanced online formatters, and (4) integrated word-processing programs (Pfaffenberger, 1986). Text editors and batch-formatting programs were designed and used before the advent of microcomputers. When using a text editor, compositions are simply written as text files and contain only the symbols of keys avallable on a computer's keyboard. A batch-formatting program allows one to feed a text into a computer, wait for the document to be processed and then recelve a hard copy from the printer. Beginning in the late 1970s, online formatters became available with the development of microcomputers. Online formatters allow a writer interactive contral of the composition s/he is writing. The most recent form of word processing is the Integrated program. Such a program not only provides interactlve control, but also may furnish the use of a dictionary, spelling checker, thesaurus, data base, spread sheet or ldea processor.

Text analysis and batch-formatting programs were orlginally designed for and used with mainframe computers. The less expensive microcomputer was not publicly available until the late $1970^{\prime} s$. With the advent of microcomputers and the utility of onllne formatters and integrated word 
processing programs, educational institutions began to acquire and use this new technology. Also, microcomputers have been slow to be accepted and used in the language arts curriculum areas of most schools. Since online formatters and integrated word processing programs are less than a decade old, and fairly new to those in the language arts portion of the curriculum, It is understandable that there has not been an abundance of investigation related to the use of these tools. Yetta Goodman (1984) writes:

The impact of home minicomputers and the new computer age in general on the functional principles of li teracy that children develop can anly be speculated about at this time $(. .$.$) , but$ that this understanding of 1 iteracy will appear in the play and real use of written language by children between the ages of 2 and 5 is unquestionable. (p. 107)

Dillon (1985) shares:

While we know little about language and learning in classrooms generally, we know even less about the structure of knowledge and style of language in computer software and how pupils interact with it in order to learn. (p. 96)

Though research is not extensive on the use of word processing, some documentary literature is available, written by those experienced with the use of this tool. In his book Writing With A Word Processor, author Will iam Zinsser (1983) writes of hls computer purchase and use of a word processor in the early $1980^{\circ} \mathrm{s}$. Among his findings: ( 2 lnsser 1983), "Another novelty that I hadn't expected is that the word processor makes writing a public act" (p. 44). Monitor 
screens provide a visual display of text or graphics associated with the software being used with the computer. The cathode ray tube (CRT), synonymous with monitor and television, is a common artifact in today's society. Not only do most Americans possess a television, they are also present in many commercial settings. From walking in the door of a business and seeling oneself on a monltor to watching the latest styles dance across the TV screen at a fashion boutique, we have become famillar with the universality of television viewing. As $Z$ insser and others have reported, writing with a word processor places the writing process in the public domain (Bickel, 1985; Bruce, Michaels \& Watson-Gegeo, 1985; Daiute, 1985; McKenna, 1986; Worsley, 1985).

Scholars have written of changes they have experlenced, or which they envision will occur when using a word processor (Arms, 1983; Blask, 1986; Branan, 1984; Bridwell, 1984; Crist, 1984; Halpern, 1984; Marshall, 1984; Papert, 1983; Schwartz, 1982; Spencer \& Baskin, 1983; Thompson, 1983; Watt, 1983). After Jamieson McKenzle (1984) completed his dissertation using a word processor he wrote,

Those who spend hundreds of hours writing with the word processor can report major transformations of style, productivity, and process. Fluency grows, flexibility develops, and orlginality springs from its hiding places. Liberation from the fear of errors can set creative expression in action. (p. 56) 
This, from an inltial investigation into the use of word processors, and at an adult level.

Research conducted on the use of word processors in. writing has been done at all levels of education. At the secondary level (middle school through callege) many of the investigators have noted changes in students practice of revision (Plper, 1984; Selfe, 1985; Simon, 1984). Among Diane Ehrlich's (1985) observations of junior college students, she notes that they revised more hollstically and not just at the surface level. Ann Duling (1985) observed among 9 th grade subjects that "Students were found to have made significantly more revisions at the sentence and multi-sentence levels of their texts than expected." Another researcher found that middle school students apparently spend more time in revising their text than through traditional means (Koening, 1985).

Teachers have written of the changes and advantages their students have experienced using a word processor (Bickel, 1985; Selfe, 1985). Gail Womble (1985), a high school teacher has expressed it as follows:

How does a word processor affect student writing? I'm able to make several observations:

1. I've observed that students using a word processor often become more fluent writers.

2. The changes students make in their writing tend, at first, to be surface level (editing). Until they have had experience with 'real' revision, they tend to 'revise' the way they know how, by correcting mechanics or recopying to make their papers look neater. The word 
processor helps these students to stay longer with a piece of writing and to experiment more with additions, deletions, etc. These changes can be made easily and feedback is instantaneous.

3. With clean and readable copy, writers are better able to continue on to the important business of revision. Problems with handwriting a illegibility are no longer obstacles.

4. Many students will choose not to revise at all if revising means going to all the extra work of recopying page after page. The word processor saves them from copying and recopying every time they make a change.

5. Wrlting with the word processor helps students become more aware personally of writing as a process. They are able to articulate clearly and decisively the process they follow. (p. 76)

Exploratory research on the use of microcomputers with word processing programs has been conducted in various settings. These settings range from solo computers in a classroom to computer labs containing multiple microcomputers or terminals (Arms, 1983; V.N. Bradley, 1982; Brent, 1985; Ehrllch, 1985; Heap, 1986, Mlller, 1984). These varlations have also occurred across levels of education al though there appears to be more Investigation conducted in lab settings at the secondary level.

of the investigations conducted with elementary age students, a trend emerges; older students have access to a computer lab while younger children use a computer in their classroom. Subjects in Sam Miller's (1984) research, sixth graders, wrote in a lab setting. Phenix and Hannan's (1984) subjects, first graders, had the use of one microcomputer in their classroom. Such a discrepancy in computer availability 
appears to be the norm except for a few schools using IBM's "Writing to Read" program (Educator's Report, 1986; Guttinger, 1985; Ohanian, 1984; Powell, 1984; Wallace, 1985).

Bradley (1982) reports on two exploratory studies dealing with the use of word processors in elementary schools. One study investigated sixth graders using word processors for combining sentences. The other centered on the usefulness of a word processor and the language experience approach (LEA). In the LEA study, adults took dictation from individual first grade students during a small group setting, word processed the stories and printed coples for each member of the group. Although these young students did not have an opportunity to directly handle the equipment, they were apparently influenced through this experience. Signlficant aspects to this study reported by Bradley are, (1) children had the experience of seelng how quickly their dictation was transcribed, (2) each of the storles was longer than a typical LEA story, (3) the ease at which children could make changes and corrections as they created stories was demonstrated. (4) and also shown was the computer's capability to produce hard copies. Each of these outcomes was a learning factor in each child's understanding of a computer and the word processing tool.

In a study conducted by Phenix and Hannan (1984), chlldren in a grade one classroom were told at the beginning of school in September that they were expected to write daily 
throughout the year. Later in the Fall, most children had an opportunity to be involved in a six-week pilot classroom project using a computer system with word processor. Through their investigation, Phenix and Hannan (1984) observed a number of different phenomena relating to both print literacy and computers. One of the findings of this study demonstrated that reading and writing are intertwined. An initial activity observed by Phenix and Hannan (1984) was that chlldren would retrieve their work from the prevlous day and reread what they had written. They also found that, in most cases, children would contlnue with the writing which they had begun the previous day. As others have speculated, children were also spending more time composing, apparently due to their enjoyment of using the computer (Eagan, 1984; Fisher, 1983; Kurth, 1984; Sommers \& Collins, 1984). By reading, rewriting and continuing their work from the previous day, chlldren integrated the development of literacy skills.

In relationship to the ease of revision. Phenix and Hannan (1984), as well as others, observed that this tool allowed children to take $r$ isks in thelr writing (Worley, 1984). These first graders always had the opportunity to easily and effortlessly erase part or all of a word, sentence or thought (Humes, 1982).

Phenix required her students to print hard copies dally. This procedure afforded children the opportunity to see their 
own successive drafts. Also, as others have speculated, as they compared these drafts, the children evolved an awareness of the manipulative possibilities of letters, words, sentences and thoughts (Crist, 1984; Marshal1, 1984; 01ds, 1985; Piper, 1983-84; N. Smith, 1985; Worley, 1984).

Phenix and Hannan (1984) also report transfer of writing concepts by students. When the word processor was not available, children continued to be concerned with grammar, punctuation, and spelling as well as to rewrite, insert, and delete in their handwritten compositions. Phenix and Hannan (1984) write:

They had learned that writing does not have to come out right the first time, that it can be manipulated by the author, that a writer has to take risks, that revising is the normal way writing is done. (p. 812)

An additional composing skill that chlldren were observed developing was formatting. Within a few days of using the word processor, children were aware of the Importance of space within their compositions. Students realized the use of space for separating words. In conjunction with formatting, a printed copy of the composition appears perfect. This allowed children to easily identify printed letters, words and thoughts.

Phenix and Hannan (1984) observed all phases of the writing process during their classroom investigation. Children of varied abilitles and experiences used this new technology. In summary the Investigators (1984) write: 
The children we observed were already practiced in composing, through their talk, dramatic play, painting, and their experiences with 1 iterature. When their writing was not 1 imited by their ability to print and spell, the length, fluency, and literary quality of their pieces increased. In turn, the quantity writing led to better facility with printing, and a development towards standard spelling. The computer proved to be a powerful tool in enhancing the children's composing and transcribling skills. (p. 812)

In another school setting with first grade chlldren. The Bank Street Writer word processing program was used with billngual children to assist in the development of their English literacy. Children had the opportunlty to spend approximately 15 hours over a three month period towards the end of the school year writing with computers. Brisk and her colleagues (1985) Intended their educational approach to teach students the value of writing, to tell a story.

In this study, the investigators found that they could classify the skills of the children durling the students' initial encounter with the computer.

Some used the word processor wi thout hesitation and with a fair degree of accuracy. others seemed to recognize the letters, but took some time to write. Still others wrote with great difflculty. And a few had problems wrlting but could still accurately prompt peers when they were having dlfficulty. (p. 27)

However, Brisk (1985) writes: "Language and reading ability did not always relate to students' initlal reaction or ability to use the word processor" (p. 27). In addition, during their initial interactions with the word processor, students were observed to have some difflculty with the 
mechanles of this new technology. Students soon discovered that pressing a key for too long resulted in repeated letters. Since the keys on a keyboard are pictured as capitals, this caused some confusion. The most obvious difficulty is that capital "I" is often interpreted by children as a lower case "l".

Although the emphasis was not on teaching word processing skills, many of the children learned to perform such skills to varying degrees. During this project, teachers explained editing and printing procedures to the children as they performed them. Instructions written on poster board in Spanish were displayed in the room. As chlldren continued to work in this environment, many eventually learned to manipulate the word processing software functions.

Just as Phenix and Hannan (1984) observed, Brlsk and her colleagues (1985) report some chlldren simply wrote letters, numbers, words or combinations of these without any particular meaning. Brlsk (1985) explains that these were the less advanced students. Another interesting concept Brisk (1985) reports is that "Nelther the word processor nor the printer revealed the ldentity of the "real' author" ( $p$. 28). Chlldren could work together, copy another's writing, work with an adult, and then print their composition. The resulting letters, numbers, words or comblnation of these did not necessarily reveal the "real" author. 
The popular press in the past has often voiced a concern related to the "social disassociation" that computers will have on chlldren. Word plctures have been drawn of a child isolated and detached from reality in his or her room concentrating on a computer. Brisk (1985) and her colleagues found that children were not isolated in their work with a word processor. There were constant interactions among adults and children. Adult exchanges appear generally to be in the realm of assistance with either the mechanics of the word processor program or with composition. Children became peer tutors as they helped one another. Brisk (1985) and others have found that there are many opportunities for children to discuss concepts and language while they compose with a word processor (Kurth, 1984; Mehan, 1984). Brlsk (1985) and her colleagues attempted to create a rlsk-free environment where children could experiment with wrltten and oral language, and to allow for the natural development of literacy. The children involved in this project represented all abllity levels. In conclusion the author writes, "This project demonstrates that the computer can be used to develop literacy among very young children regardless of their initial ablilty to read or wrlte" (p. 31).

The researcher Heap (1986) deslgned a study to observe first grade students and their collaborative practlces when writing with a word processor. In the research setting, 
while students were involved with the word processor they also had a "helper" student ready to assist. Heap (1986) writes:

The helper position in the classrocm arises somewhat spontaneously, according to the teacher. Each year in her class, the students who are the quickest to pick up the fundamentals of using the computer for story writing hang around the computer offering advice, until an actual position called "helper" is institutionalized by the teacher. ( $p$. 2)

Thus there were two people working together at the word processor collaborating on a written composition.

Heap (1986) found children interacting with one another when composing and that their" writing process became "... bi-modal. It was done as physical acts, of finding and depressing keys, but also as verbal acts of pronouncing the letter being input" (p. 8). Both the writer would say the letter names or words to $\mathrm{him} / \mathrm{h}$ erself as the text was imputed or the helper would share the discussed text verbally. Heap also writes that the children coordinated their writing and suggestions very carefully as they worked together: "I observed no cases of a student dictating an entire word, or a sequence of letters, without timing the delivery of the dictation to alternate with inputing" (p. 17).

Heap (1986) also found that chlldren's verbal sharing extended to thelr arrangement of text. They would tell one another what was needed were in order to format the text the way they wanted It. This Included telling where to leave a 
space. Heap (1986) points out that in stylus writing the author leaves a space whereas with a word processor the author puts a space where needed. In conjunction with putting spaces and use of the space bar, Heap (1986) found: "Arranging, as it was done by the first graders I observed, primarily involved cursor movements and deletions" (p. 20). During this study Heap (1986) became aware of the many language arts skills chlldren utilized as they collaborated with one another.

Word processing ... virtually requiring, students writing together to use all of the lanquage arts. During my observations, students spoke. They listened. They obviously wrote, but, as the prevalent oral reading practice made clear, they also read what they had verbally composed and verbally input. Hence, the use of the computer had a value that transcended development of the single language art whlch computer writing would otherwise appear to serve. (p. 24)

Seymour Papert (1980) and others (B. Bradley, 1983;

Dillon, 1985; Schantz, 1983; Worsley, 1985) write of "empowerment" for children in their use and control of computers. Investigations into this concept of "empowerment" have occurred by focusing on the concept of locus of control (LOC) (Louie, 1985). CAI (Computer-Assisted Instruction) and related courseware materials control the teaching situation and students (Alessi \& Trollip, 1985). Students respond to visual stimulus from the screen or auditory stimulus from an attached electronic speaker. The courseware contlnues to prompt students through its program of instruction, walting 
and only allowing certain responses. In this fashion, students are controlled by the electronic media and hardware. In their study of young bilingual children, Brisk (1985), notes, "Word processing permits children to impose standards and 1 imits rather than imposing rules on them" (p. 32). Children are in control of the computer and courseware through the use of interactive software such as a word processing program (Newman, 1984B; Piper, 1984; Schantz, 1983).

In summary, there are many exciting possibllities for the use of computers in our world (Evans, 1979; Toffler, 1980). Microcomputers, using word processing software, appear to hold great promise for the development and use of literacy skills. Goelman (1984) summarizes notes from a recent symposium on literacy: "Computers could have profound effects on society in general and literacy in particular" ( $p$. 211). When using a word processor, writing suddenly becomes public. A word processor also allows one to take risks and easily play with written language. And when used in conjunction with process writing Daiute (1985) states: "The computer is the perfect tool for a process approach to writing, because it makes revising and recopying texts physically easy" (p. 66). Brlsk (1985), Clements, 1987; Heap (1986), as well as Phenix and Hannan (1984) have demonstrated that First Grade students can use a word processor. Even 
though research is 1 imited, scholars have written glowingly of the use of these tools in education.

\section{SUMMARY}

The evolution of the human specles' 1 Iteracy and cognitive development has been continuous for thousands of years. An outgrowth of our early thinking and initial oral and gesture communication was and is the evolution of writing. At different points during this evolution, technological changes have revolutionized the development of literacy. Presently, we are at the beginning of another technological revolution which may have tremendous impact upon human cognitive and literacy growth and development.

Other than those first precious five years of 11 fe, the following two to three years hold the most extensive cognitive and literacy development for humans. During these years, children move from the preoperational stage of cognitive development to the concrete stage. Their literacy development is characterlzed by a greater understanding and use of rules and conventions associated with written 1 anguage.

During the last 15 years there has been a reexamination and investigation of the human specles' writing process by educational scholars. The writing process is not only an aspect of mature writers, but that of developing writers as well. Durling this same time perlod our specles has developed 
a new literacy tool, the computer. When programmed with word processing software, the computer has the potential to allow easy manipulation of words, phrases, and thoughts. Many glowing reports have been written about this so often revered tool. However, few emplrical studies have been conducted. There has been 1 ittle investigation into young childrens' use of a word processor assoclated with their print literacy development.

The findings of this study may provide further understanding of young children's use of a word processor as our society evolves into the Information Age. 
CHAPTER I I

RESEARCH DESIGN AND METHODOLOGY

INTRODUCTION

Wilson (1977) writes: "There is a growing interest in the use of anthropological techniques in educational and psychological research" (p. 245). Ethnography, descriptive, and naturalistic inquiry - "qual itative research" - is increasingly being used in classrooms and schools throughout the United States as an investigative method. Wolcott (1984) states: .

\begin{abstract}
If descriptive research--or 'quall tative' research, as it is fortultously called--is not about to unseat quantitative research as education's king of the mountain, it has at least earned a place as one of education's legitimate and important ways of knowing (p. 177).
\end{abstract}

Two other scholars, Guba and Lincoln (1981), writing about the usefulness and lmportance of naturalistic inquiry state: "It is our position that the naturalistlc paradigm is the more useful for all social-behavloral inquiry and certainly for responsive naturallstic evaluation" (p. 56).

During the past 100 years, a number of naturalistic studies in the field of psychology have provided a basis for related investigative methods. As Agnew and Pyke (1969) write: 
The work of Plaget, the famous child psychologist, and that of Sigmund Freud was based on the method of naturalistic observation, and is the foundation for much of the current research in some areas of psychology today. Although at times this method is comparable to a crude sieve, it is still a valuable source of important and durable data in the hands of a skilled researcher (p. 63).

Ethnography offers useful tools in social science

evaluation and research. Ethnographic techniques are increasingly being included in present day educational research and evaluation. Fetterman (1984) writes: "... ethnographic techniques in partlcular have been used successfully to provlde useful insights into numerous educational and social problems" (p. 13). The use of ethnography as a research method in education has also been documented by Wolcott (1984) who suggests it is important ...to help educators recognlze the value of descriptive research conducted in natural settings rather than to rely so wholeheartedly on experimental research in contrived or controlled settings ( $p .177$ ).

Lescriptive research in a natural setting has been an important component to recent investigations of children's writing (Baghban, 1984; Bissex, 1980; Calkins, 1983; Graves, 1983, 1984; Harste, et al. 1984; Heap, 1986). Donald Graves (1984) shares: "Writing is an organic process that defles fragmentary approaches to explain its meaning ..." (p. 95). This initial research of the writing process has eventually led to a change in the way writing is perceived and taught in many American schools. In her book Lessons From A Child, 
Calkins (1983) describes her use of case study to follow Susie, her subject, through two years of writing development and evaluation. Such an approach is typical of inquiry into a relatively new field or area of study. Kosecoff and Fink (1982) wrlte:

\begin{abstract}
Evaluators typically use case designs to answer questions that ask for a description of a program's participants, goals, activities, and results. Questions about new programs or demonstration projects for which comparisons are not yet available almost always require case design strategies (p. 81 ).

The use of computers and especially microcomputers in
\end{abstract} education is a recent phenomenon. As demonstrated in Chapter II, little investigation has been conducted on the relationship of children's literacy development and the use of microcomputers programmed for word processing. Since little is known empirically, it is important to conduct research in this and other educatlonal areas influenced by technology (Daiute, 1985; Sheingold, 1983; Spencer, et al., 1983; Weizenbaum, 1983). Halpern and Liggett (1984) write:

Toplcs for research in technologlcal change are as diverse as the new technologies themselves. ... many intriguing questions about the effects of the new technology on writing remain ( $p .85$ ).

Collins (1985) further clarifies the issue of investigative approach and the association of chlldren's literacy development and technology:

If we wish to learn about the role of computers in child literacy and thelr effect on children's learning and 'languaging', we'll need to spend much time in classrooms with chlldren and 


\begin{abstract}
computers to study closely and carefully what happens there. Despite the amazing degree of interest in computers, I have found very little work describing and analysing what actually happens with them In classrooms, ... (p. 102).

Two investigations, with concerns similar to those
\end{abstract} addressed by my research, have been reported. Both studies were with first grade students. The Brisk (1984) investigation was conducted over a three month period, with first grade children having approximately 15 hours contact with a word processor in a computer $l a b$. Phenix and Hannan (1984) had one computer available in a grade one classroom for six weeks. This study focused on children one year younger, kindergarten students, who had daily access to a word processing center in a literacy lab over a five month period. Although a portion of this research has been a verification of these earller investlgatlons, Moore \& Cooper (1982) write:

The findings of an Indlvidual research study, no matter how carefully done, or how relevant to practice, should not be given excessive weight by the practitioner. It is not untll we have at least four or five studies, ideally more, all of which address the same general research question and suggest the same general conclusion, that we can have confidence in the statements to be made about behavior from our research ( $p .8$ ).

\title{
RESEARCH PROCEDURE
}

I modeled my research framework in part after that of Donald Graves (1984) of the University of New Hampshire, and his suggested approach to the study of the writing process. 
He proposes that the study of process is the most

enlightening approach a researcher can take in his/her study of writing. Graves (1984) writes: "We need more information on child behaviors and declsions during the process, rather than through speculation on chlld activity during writing from writing products alone" (p. 93). A number of authorities have written extensively about their study of process through the technique of case study (Baghban, 1984; Bissex, 1980; Calkins, 1983; Chomsky, 1971; Harste (1985); Taylor, 1983). In regard to the investlgation of process through the use of case study, Calkins (1983) writes:

My hope is that through closely observing one child's growth in writing, we'll learn to watch for and to respect each child's growth in writing. My hope is that by understanding the pathways one child has taken in learning to write, we may be able to discern and trust the pathways other children will take (p. 7).

Noted scholars of the qualitative approach to research suggest that although a research procedure is designed, this research method possesses an Inherent quallty of accepting change (Miles \& Huberman, 1984; WIlson, 1977). Guba and Lincoln (1981) write:

Within the naturalistic paradigm a design can be specified only incompletely in advance. To specify it in detail would be to place constraints on the inquiry that are antithetical to the stance and purpose of the naturalist. The design emerges as the investigation proceeds; moreover, it is in constant flux as new information is gained and new inslghts are achleved ( $p .73$ ). 
In his book, A Researcher Learns To Write, Donald Graves (1984) shares his approach to writing research with the following model. This model is in the shape of an equilateral triangle sectioned into four levels. As illustrated in Figure 3.1 , the top two levels deal with process, which requires case study observation, while the lower two levels focus on analysis of product.

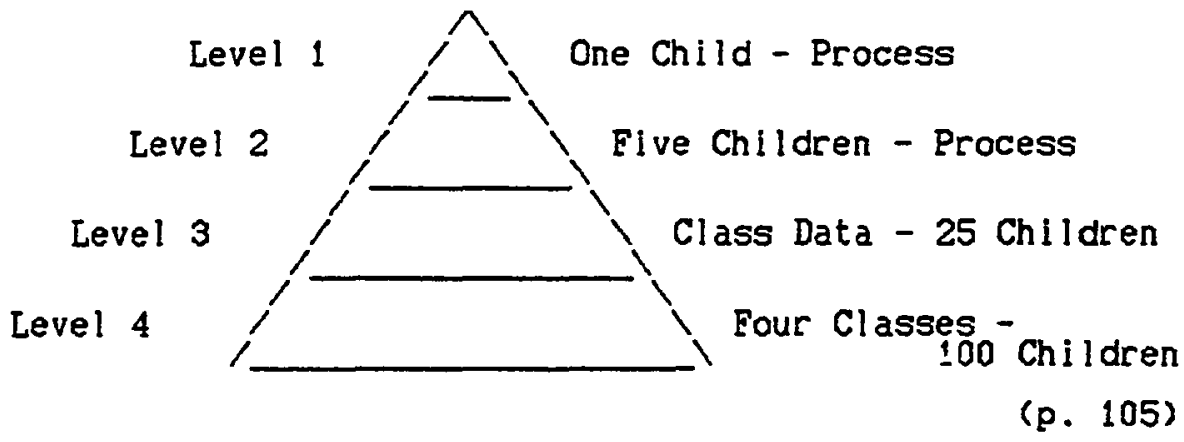

Figure 3.1 Example of Donald Graves's writing research study design.

Following Graves' model, Level 1 requlres an indepth case study of one child. It requires an observation of a child prior to, throughout, and following interactlon with word processing as the child's I iteracy continued to evolve. Graves (1984) writes: "... the full context of writing episodes are gathered from before a child writes until the child has had a response to his product" (p. 105). Children assoclated with Level 2 of this diagram are followed in a manner similar to Level 1. Research associated with subjects 
in Levels 3 and 4 requires the collection and analysis of products only. Again, Graves (1984): "... product analysis is given to four classes within the same school building, but also including each of the first three levels of the study" (p. 105).

In this study, the researcher proposed to follow six students in a simllar manner to Level 2 of the Graves' design. The selection of six children allowed the observation of students from varled backgrounds and of both genders. Subjects with a variety of backgrounds provided an opportunity to look for simllarlties and is a reflection of research setting's diversity. This design also protected this investigation in that if one or two students left the school, thls study could continue with the remaining subjects.

Although there was only researcher and observer in this study, a variety of data collection methods and multiple observations were employed in order to reduce the amount of error in this investigation. Agnew and Pyke (1969) state:

... the same observer may try to observe the
same event many times in order to ensure that he
has noticed all the relevant detalls and to rule
out the possibility that his inltial observation
was a once-in-a-lifetime event (p. 58).

The use of multiple avenues of data collection is supported by the writings of Diesing (1983): "The reason for having multiple types of data is that there are no infallible data in ethnography, nor anywhere in the social sciences" (p. 3 ). 


\section{PARTICIPANT OBSERVATION}

The researcher's role during this study was not only that of research observer but also that of participant. As a member of the staff, where this research took place, one responsibillty the researcher had was to provide leadership in the area of literacy development to the prekindergarten through second grade teaching staff. Therefore, the researcher is a member of the immediate school environment including the Writing Lab. Many students have known the researcher since their enrollment in the School's Kindergarten and some, since they attended the School's 4 Year old program. The researcher was frequently in Klndergarten classrooms, the Writing Lab, and other parts of the building. It was not unusual for students to observe $\mathrm{hlm}$ in a teaching or adminlstrative role.

Various scholars have written about and defined the partlclpant observer role (Fetterman, 1980; Guba \& Lincoln, 1981 ; Shuter, 1976; Wilcox, 1982; Yin, 1984). Shuter (1976) writes:

\footnotetext{
Particlpant observation, ...., can be defined as a fleld strategy that simultaneously combines respondent and informant interviewing with direct participation and systematic observation (p. 3 ). Another definition which more closely describes this researcher's involvement in this study has been written by Guba and Lincoln (1981):
} 
We prefer to deflne particlpant observation as a form of inguiry in which the inquirer-the observer-is playing two roles. First of all, of course, he is an observer; as such, he is responsible to persons outside the milieu being observed. But he is also a genuine participant; that is, he is a member of the group, and he has a stake in the group's activity and the outcomes of that activity (p. 189).

Guba and Lincoln (1981) further describe the use of observation in research:

The basic methodological arguments for observation, then, may be summarized as these: observation (particularly partlcipant observation) maximizes the Inquirer's ability to grasp motives, beliefs, concerns, interests, unconscious behaviors, customs, and the like; observation (particularly participant observation) allows the inquirer to see the world as his subjects see it, to live in their time frames, to capture the phenomenon in and on its own terms, and to grasp the culture in its own natural, ongoing environment; observation (particularly participant observation) provides the inquirer with access to the emotional reactions of the group introspectively-that is, in a real sense it permits the observer to use himself as a data source; and observation (particularly participant observation) allows the observer to bulld on tacit knowledge, both his own and that of members of the group $(p$. 193).

The authors of Effective Evaluation, Guba and Iincoln (1981), provide a graphic, illustrated in Figure 3.2 , which represents their interpretation of a subject's awareness and degree of an observer's interaction in the study setting. 


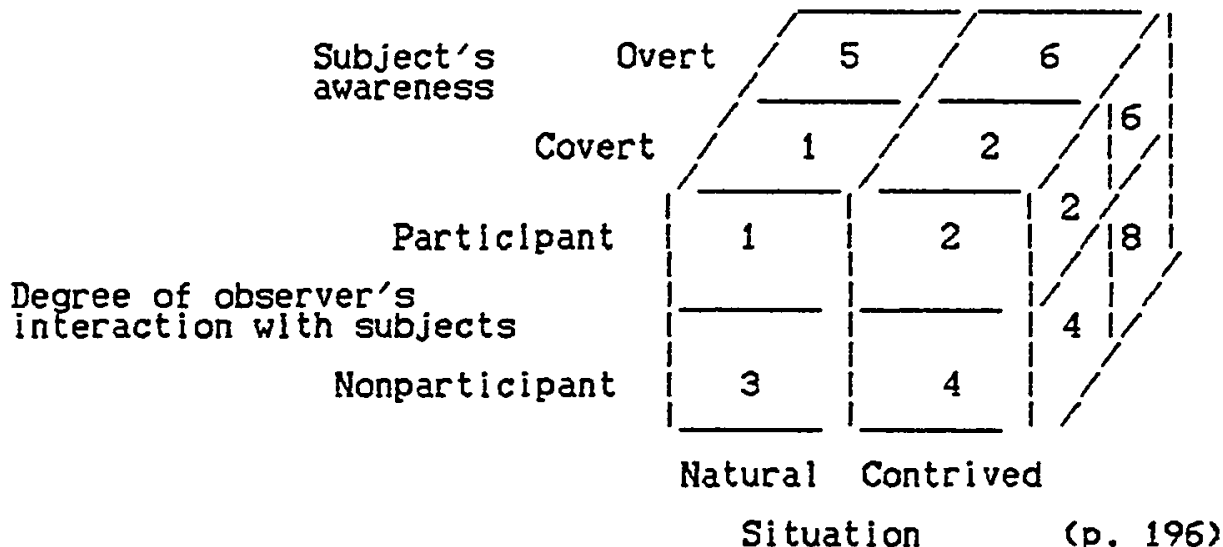
Fiqure 3.2 Example of Guba's and Lincoln's Figure 4. A Typology

In this study, subject's awareness was both overt and covert. Much of the time, students were aware of the researcher's presence while he was observing, recording data, and taking notes about their behaviors. However, there were times when they were not overtly aware of his participation In the word processing center and the Writing Lab. To further clarify the degree of the researcher's Interaction with subjects, there were times when he was a participant in their learning and use of the word processors as well as times when he was strictly a nonparticipant.

The researcher was both a particlpant and an observer in this study.

\section{PRELIMINARY RESEARCH ACTIVITIES}

There were three data collecting components assoclated with this study. These components are delineated in Figure 3.3. The initial components were extremely helpful in 
preparing for the formal observations and refining and analysis of the data.

Pre-preliminary Research

Dctober through December 1985

Subjects: full class of flrst grade students

Survey of research methods, observational practlce and design of data collection instruments.

Prel iminary Research

January through December 1986

Subjects: 7 children moving from kindergarten to first grade during the year

Observation and data collection of kindergarten and first grade students and continued design of data collection instruments and refinement.

Formal Research

January through June $198 ?$

Subjects: 6 kindergarten children

Observation and data collection of kindergarten students.

Flqure 3.3 Time line dlsplay of the three data collection components to thls study Data collectlon was conflined to the word processor center in tie "Writing Lab."

Beginning in October of 1985, the researcher began to collect anecdotal recordings in the Writing Lab ("Writing To Read" Lab) at the school. Subjects at this time were $f$ irst grade students who were completing a year's contact in the writing lab. They had been using word processors since the beginning of September. The researcher began these preliminary observations in order to better understand the research setting and the children's computer interactions, and to develop a research framework for recording data. These observations were helpful in the formulation of questions, the development of recording instruments and approach, and in establishing the investlgator as a research participant observer. Perl (1983) writes: 
It's commonplace to say that we'll never learn how to write solely by reading about it or studying what writers say about it, similarly budding ethnographers won't learn the methods and procedures of ethnography merely by reading or studying accounts of other anthropologists (p. 11).

Guba and Lincoln (1980) share:

Another way to train oneself for observation is to set tasks related to looking, llstening, and recording skills and to keep performlng those tasks until the confidence that goes with solid performance is achieved (p. 211).

This informal investigation led to additional

preliminary investigation. Beginning in January 1986, the researcher employed the Graves model to begin an investigation of kindergarten children's use of a word processor and their literacy development. This preliminary investigation continued for one calendar year. From January to June 1986, during their last six months of kindergarten, the researcher studied seven children as they used word processing. He continued in september of that same year to observe the same subjects as they used these machines. These first four months of the subjects' first grade experience completed one calendar year of study.

The preliminary research which occurred during 1986 encompassed the first two levels of the Graves paradigm: 1 , one-chlld case study; 2 , flve-student case studies (six were used in this study). The focus in these levels was process, which has also included an analysis of students' products. These case studies provlded the researcher with an indepth 
view of children developing their print literacy using a word processor. This approach provided an opportunity to practice naturalistic research techniques. It also provided an insight into many of the processes which the researcher antlcipated would be abserved during the formal data collection periad (Guba \& Lincoln, 1981). Through testing and use of the model and ethnographic techniques, the naturalistic research design was modified and the investigator's skills as a researcher and observer matured.

\section{RESEARCH SETTING}

\section{The research setting was in an inner clty early} childhood education center (ECEC) in the Pacific Northwest of the United States. This particular school has a cosmopolitan encollment with students ranging in age from four to eleven years of age. Four years ago, we were given the technology to establ ish an IBM "Writing To Read" Lab (Writing Lab), an early print literacy program authored by John Henry Martin (1984). The technology origlnally assoclated with thls IBM program consisted of three computers dedicated to computer assisted instruction (CAI), 6 Selectric typewrlters whlch students could use to copy their written work, and cassette tape playback machines functioning as 1 istening posts for children's literature books and workbooks. Two and one half years ago the school was given six computers capable of using word processing software. As a result, the school's Writing 
Lab contains six IBM PcJrs in addition to the original three computers primarily dedicated to CAI. These additional six computers comprise the word processor center. Within the word processor center, two printers are color coded and networked to the word processors. Each printer supports three word processors.

As 1 llustrated in Elgure 3.4, the school's wrlting lab contains eight learning centers in a two room complex. The main room contains the vast majority of students at any one time. A listening center, which can accommodate 4 to 6 children, is located in a small auxiliary room which is also used for storage. Unless they are speciflcally assigned, or a particular learning center is full, children have access to the entire writing lab. 


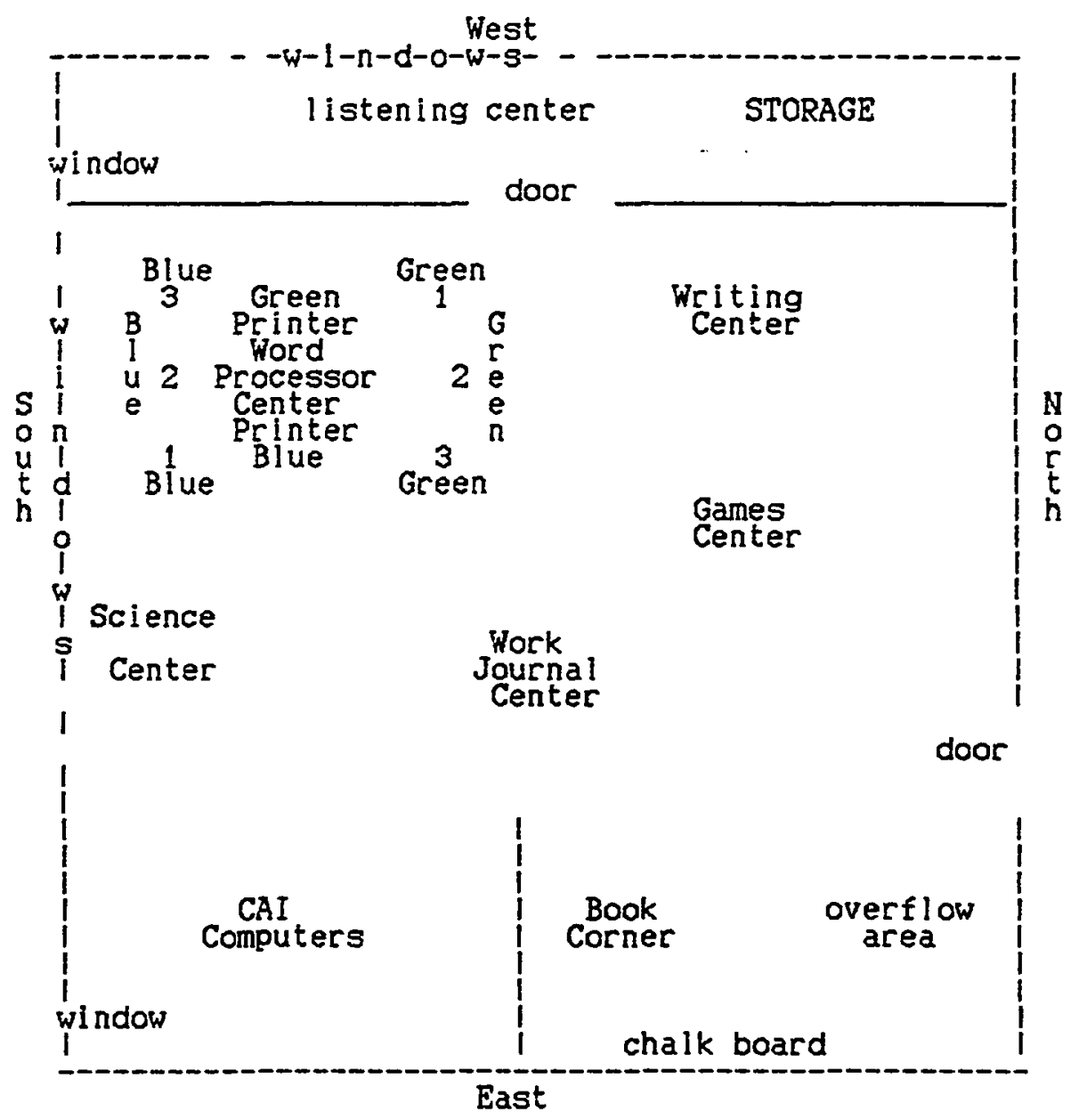

Eigure 3.4 Diagram of the school's wrlting lab deplcting learning centers and position of the six word processors.

Assoclated with the school's wrlting lab is the IBM

"Writing To Read" program and related software. This software is a CAI phonles program whlch also includes audio tapes and workbooks. The CAI phonics program conslsts of ten cycles, each introducing a few phonemes. Following CAI lessons with these phonemes, students must pass a computer mastery test in order to advance to the next cycle. Although 
this software is available, the teaching focus is written and oral language immersion.

Bank Street Writer, the word processing software used with these computers, is capable of belng presented in both monochrome and color displays. The monochrome screen consists of a black background with print and format items in all modes presented in white. Color screens also consist of a black background but include blue format 1 ines and some print in different highlight colors. Color highlights are present in both the writing and edit modes.

Alternating daily and skipping every other computer, three of the computers were booted with software to produce monochrome screens while the others were booted with software to support color screens. Thls booting process resulted in computers on either side of one computer having Identical screen displays which were dfferent from the middle computer. If only one computer was avallable, or a child was assigned to a specific computer, such situations were not recorded as a screen cholce. If two or more computers of different screen formats were available, children then had a choice and it was appropriately recorded.

Kindergarten students at this ECEC begin to utillze the Writing Lab in January each year. Children are elther assigned to or given the opportunity to choose from the eight learning centers contained in the writing lab. These eight centers are: 
Computer Center (CAI phonetics software)

work Journal (workbook following CAI software)

Science Center

Book Center

Word Processing Center

Writing Center

Games Center

Listening Post Center

Students have the opportunity to be active in the writing lab throughout the calendar year. During the year, most students advance to First Grade beginning in September.

All kindergarten, and later during the calendar year, first grade classes visit the Writing Lab dally. Grade level classes follow a predetermined schedule and visit the Lab each day at the same time for approximately one hour. The schedule is generally determined by teacher preference and other bullding schedules (e.g., Muslc, P.E., and Library).

\section{RESEARCH SUBJECTS}

Subjects for the formal component to this study were kindergarten students attending this Early Childhood Education Center. Approximately 57\% of the school's enrollment is composed of minority children. Majority and minority children represent all socio-economic levels. The diversity of the school's population provided the flexibility to select students from various ability levels, gender, socio-economic, and raclal backgrounds.

In selecting subjects for the preliminary investigation, it was attempted to have all gender, racial, socio-economic, 
and ability groups represented, reflecting the school's diversity. These subject characteristics were shared with teachers who were requested to suggest subjects. There were three levels of academic ability: high, those who were already reading and writing: middle, those who knew the majority of the alphabet and some sounds; and low, those who knew few letters or sounds. Of the six subjects, there was an equal balance between gender and race. Two levels of socio-economic status were represented, determined through free lunch eligiblity. These same procedures were followed in selecting six subjects for the farmal data collection period.

\section{DATA COLLECTION}

Throughout this study the researcher attempted to collect data focused on the process of budding literates using the word processor as a writing tool. Collected data in rough form consisted of anecdotal observations, copies of subject products, and colleaguel comments. Yin (1984) wrltes:

Observational evidence is often useful in providing additional information about the topic beling studled. If a case study is about a new technology, for instance, observations of the technology at work are invaluable aids to any further understandling of the limits or problems with the technology (p. 85). 
Teal, Hiebert, and Chittenden (1987) write: "For assessing early literacy, performance sample methods, along with observation, pose a promising approach" (p. 773).

This research study incorporates extenslve observation and data collectlon periods. Guba and Lincoln (1981) share:

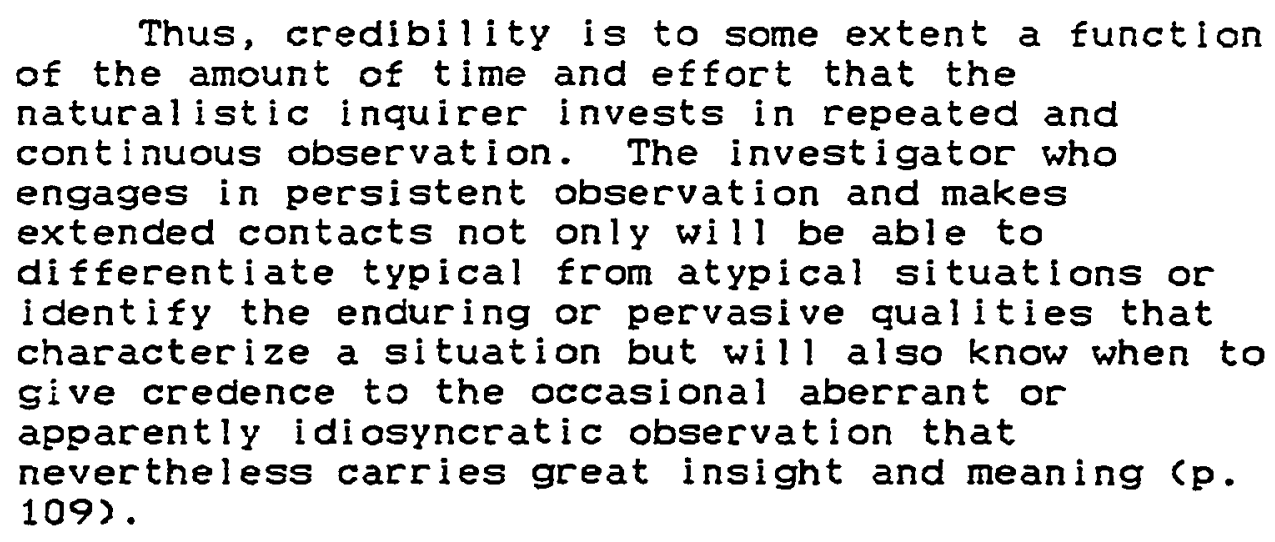

Daily observations occured Incorporating anecdotal

recordings, samples of student writlng, and behavior

checkl ist forms. Fetterman (1980) writes: "Specific patterns of behavior emerge from repeated viewings based on and placed in perspective by previous long-term observations" ( $p, 45$ ). Throughout the study perlod, student products were analyzed in association with this study's original questlons. All of the collected materlal has been used during and after the proposed period of research for evaluation and analysis of children's interactions and use of word processing in association with their print literacy development.

The researcher attempted to be in the Writing Lab on a daily basis while subjects were there. As children used a word processor, he endeavored to record the behaviors he 
observed through anecdotal recordings and or a behavior checklist which evolved during the preliminary research (Appendix A). Anecdotal recording was accomplished, through note taking with pencil and paper and/or word processor, at the research site. Some days the researcher used one of the PcJrs to write anecdotal observations. Following each subjects' use of a word processor, the researcher saved a copy of their product on a computer disk as well as printed a hard copy of their text and stapled it to his notes. At the conclusion of each session in the lab with the class, the researcher codified on charts the subject's behaviors and processes he had observed and wrote a summary note of the day's observatlons and subjects' products.

The formal data collection period of this study commenced during January 1987. In addition to the extensive data collection and analysis, the researcher continued his dialogue with colleagues. Teachers, aides, and parents have shared their inslghts, knowledge, and understandings associated with these young students and the writing process. This has continued since the early preliminary research during the Fall of 1985. The researcher has found these conversations to be most enl lghtening, Insightful, and helpful. Their insights and thoughts have helped the researcher to better understand childrens' behaviors as well as speciflc incldents. 


\section{DATA COLLECTION INSTRUMENTATION}

Beginning with the prel iminary research, the researcher continued to adapt and add to his instrumentation. This has not only included fleld note collection, but also the daily recording of behaviors associated with this study's questions. Prior to the start of the formal data collection period, the researcher created computer data bases and spread sheets in order to store and refine collected data. Levin (1985) writes about the use of computers in storage and retrieval of qualitative data:

...computerized data storage and search. ... is still in its infancy within anthropology and other social science disciplines, but is almost certain to become of increasing importance in the years to come ... (p. 171).

The researcher antlcipated that as he used recording Instruments, collected, stored, and refined data, he would find more effective and efflcient methods.

The following flgures illustrate instruments which can be found in their entirety in Appendices $A$ and $B$.

\section{Monthly Report}

This report form was used to record each day a subject was observed. The weekly checkllst Illustrated in Figure 3.5, is replicated on the actual Monthly Report form five tlmes. Week dates are recorded within the observation month. Thls completed report provides information at a glance as to 
frequency of individual subject observations and apparent patterns of recorded observations.

Monthly Report

Month

Check days children observed:

Chilaren I Monday I Tuesday Thednesday Thursday Eriday I

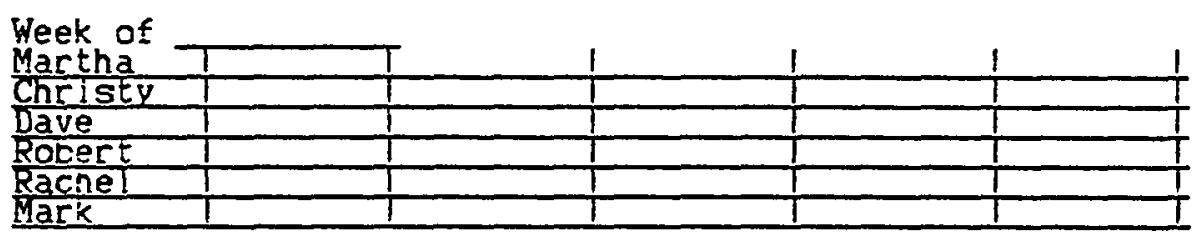

Figure 3.5 Sample section of Monthly Report form.

\section{Dally Case Study Group Data Collection}

This document, partically illustrated in Figure 3.6, was used to record the movement of each subject in and out of the word processor learning center. As lllustrated in Appendix $A$, this recording instrument was used to record a five day week. On this document was recorded the word processor used (WP used), monochrome or color screen (Choice), If the selection was a choice, and the beginning and ending times as well as total time (B $T, E T$, and $T T$ ). Room was provided in the activity column to record the primary behaviors observed while the comments column allowed space for recording additional data. 
Daily Case Study Group Data Collection Week of Day Subiect Date Date Tubject used Tholce

1

\begin{tabular}{|l|l|l|l|l|}
\hline BT & $E T T_{1}$ & Activity & Comments \\
& & & &
\end{tabular}

Flqure 3.5 Sample section of Dally Case Study Group Data Coliection form.

\section{Dally Case Study Data Collection Form}

This form, illustrated in Flgure 3.7, was used to collect daily observatlonal data. It was individuallzed for each subject. Certain data from this form were transfered to other refining instruments. This form was also used to record developmental literacy behaviors which were then transfered in a refined or indexed manner to another form. In the line "WP Used Blue $1 \quad 2 \quad 3 . .$. " the words and numbers represent specific computers. The corresponding color word and number were circled as children selected a computer and began their word processing. The term cholce was clrcled if chlldren actually had a cholce between at least two computers; otherwise, It was crossed out. The no-cholce could be due elther to only one available computer or teacher direction to a specific location. 


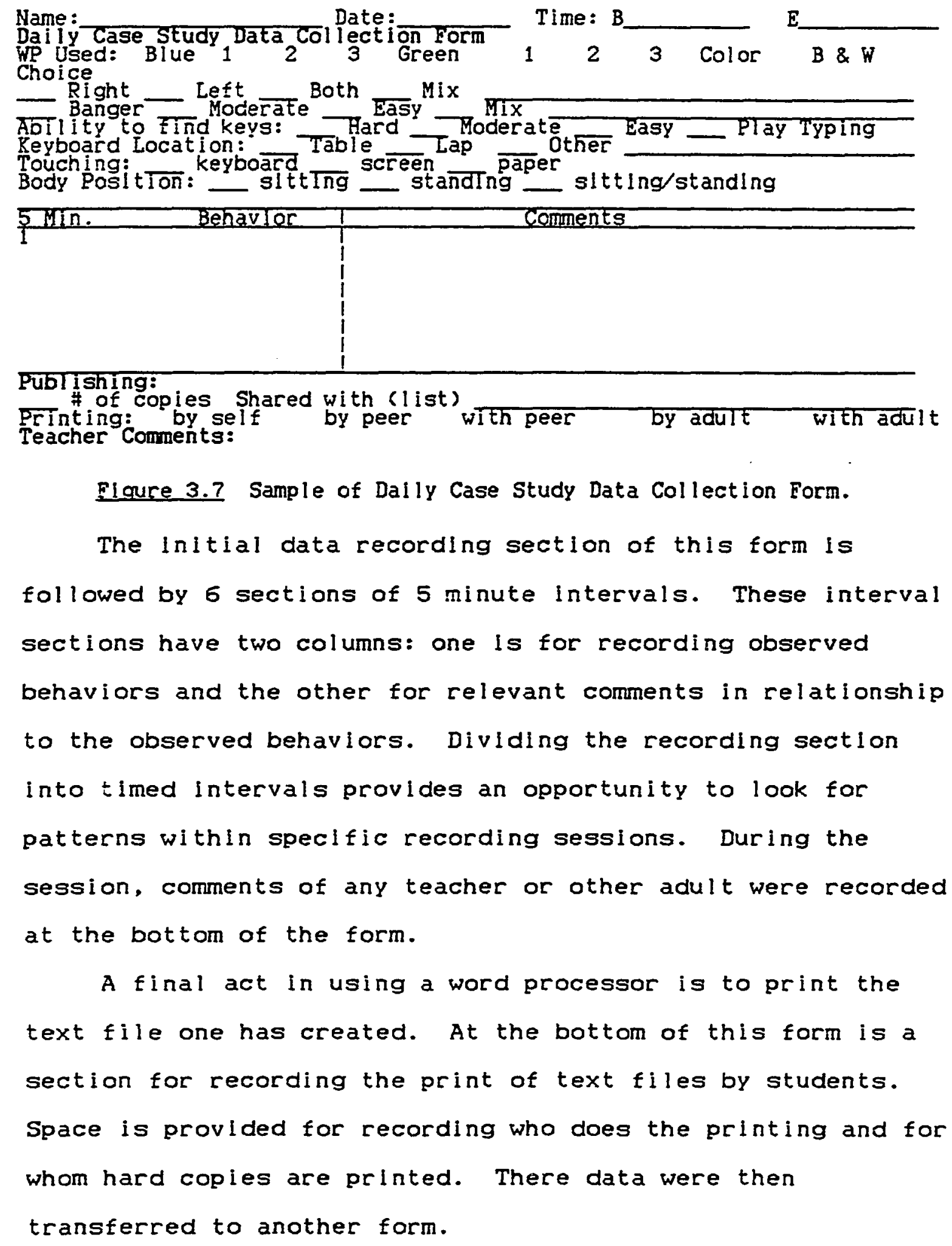




\section{Literacy Development Chart}

Data from the "Daily Case Study Data Collection Form"

were indexed and recorded on the "Literacy Development

Chart," illustrated in Eigure 3.8. This form is also

individualized for subjects. The section titled "Month or $s$ " refers to which months this form covered. Patentially, this form had space for more than one month of recorded data. During the study, It never became necessary to begin a new Literacy Development Chart. The section titled COPY refers to students copying the indexed items whereas the section WRITE refers to those ltems initated by students themselves.

Student's Name

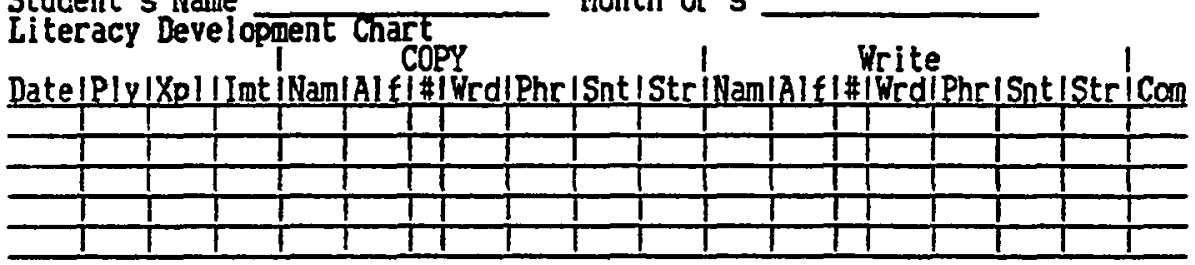

Fiqure 3.8 Sample of Literacy Development Chart form.

Through the preliminary research, the researcher observed these behaviors often with various children. In this form, the researcher anticipated the opportunity to observe patterns belng revealed. The researcher intended to take there individual subject data and reconfigure them into graph form. From such statistical forms, the researcher could then compare graphs from all subjects and look for commonal Ities. 
The following is a list of the form's headlngs and what they represent.

$$
\begin{aligned}
& \text { Ply - play } \\
& \text { Xpl - explore } \\
& \text { Imt - imitate } \\
& \text { Nam - name } \\
& \text { Alf - alphabet } \\
& \text { \# - number } \\
& \text { Wrd - word } \\
& \text { Phr - phrase } \\
& \text { Snt - sentence } \\
& \text { Str - story } \\
& \text { The researcher also recorded this information on a data }
\end{aligned}
$$

base illustrated in Figure 3.9 .

Eile: Sub Lit Data

Page 1

Report: sample

Date piy Xpl Imit Nam Alph \# Wrd Phrs Snt Stry Nam Alph \# Wrd Phrs Snt Stry

Operational Definitions of Indexed Terms:

ply - play -- no apparent purpose in mind (le. slmply running fingers

Xpl - explore - keyboard behavlors appear to be constructlve in nature

(le. appears to try out speciflc keyboard function)

Imt - imitate - copies on keyboard what $s /$ he sees another person do (le. Iml tate someone typing)

Nam - name - copies or writes part of or all of own name

Alf - alphabet - coples or writes part of or whole alphabet

\# - number -- coples or writes numbers

Wrd - word -- coples or writes a word or words

Phr - phrase -- coples or writes a phrase of multiple words

Snt - sentence -- coples or writes one or more sentences

Str - story - copies or writes a story with a beginning, middle and end

Fiqure 3.9 Sample of indlvidual subject writing behaviors data base and explanation of terms.

\section{Publishing Chart}

The manner in whlch text flles were printed was recorded on the "Daily Case Study Data Collection Form." This information was transferred to the individual ized Publishing Chart, illustrated in Figure 3.10. Recording this behavior in chart form, as a visual, provlded an opportunity to reveal a pattern if one existed. 


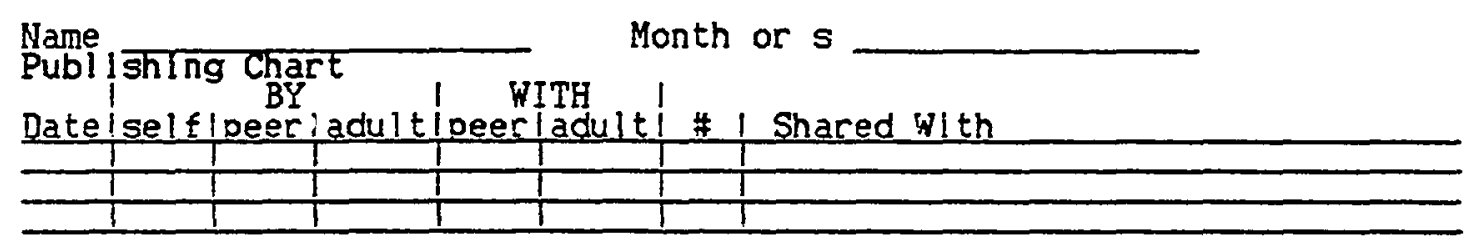

Fiqure 3.10 Sample of Publishing Chart data collection form.

Data Collection outline

Throughout the January to June case study period it was

the researcher's intention to adhere to the following schedule.

- Daily Activities: 15-60 minutes

Observe at least one of the six case study student's in the Writing Lab using a word processor.

File a summary report of the day's observations.

- Weekly Activities:

Transfer collected data from daly collection forms to the study's data bases.

\section{DATA ANALYSIS}

It is an assumed characteristic of qual itative research that data analysis is a continuous process throughout the life of a research project. Analysis of what is occurring at the field site and collected data will assist one in the evalution of a qualitative study. Miles and Huberman (1984) write:

Analysis during data collection lets the fieldworker cycle back and forth between thinking about the existing data and generating strategies for collecting existing data and generating strategies for collecting new--often better quality--data; it can be a healthy corrective for built-in blind spots; and it makes analysis an ongoing, llvely enterprise that is linked to the

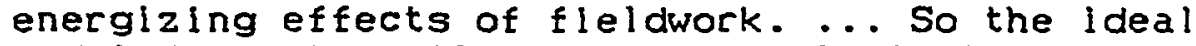
model for data collection and analysis is one that interweaves them from the beginning ( $p .49$ ).

This study reflects the position Miles and Huberman (1984) express above. As the observational data collected, there were summary reports prepared dally which forced the 
researcher to reflect upon what he had observed that day. The collected data were revlewed and analyzed daily and weekly as the researcher attempted to detect individual and group patterns, processes, and behaviors prlor to the end of the formal data collection period.

As the researcher observed student involvement with word pracessing, using the "Dally Case Study Data Collection Form" (Figure 3.7), he immediately wrote key descriptive words and then an anecdotal type description of the behavior. Following the formal data collection period he used this key word data to develop a matrix of observed general behaviors. Miles and Huberman (1984) write: "A checklist matrix is a format for analyzing field data that can be combined into a summative index or scale" (p. 95). Once the matrix was completed, he was able to compare subject's behaviors with the matrix and look for patterns and processes. This and other collected data have also been analyzed quantitatively. Agaln, Miles and Huberman (1984):

... a checkl ist format itself does a good deal to make data collection more systematlc, enable verification, encourage comparability, and permit simple quantification where that is appropriate ( $p$. 99).

Such data analysis procedures can be used for a variety of variables.

Data from issues such as "Length of time at word processor" and "Software screen color" were quantlfied statistically. It was antlcipated that it would be possible 
to calculate the mean, medlan, and standard deviation for the issue "Length of time with the word processor" and that such statistics would be meaningful. It was also possible to determine and then statistically manipulate the selected frequency of "Software screen color." Bath of these issues had the potential to be analyized monthly as well as in the long term, over the period of data collection.

The majority of behaviors associated with this research can best be analyzed qualitatively. As expressed above, there has been a continuous re-focusing and re-drawing of the study's framework. Throughout the study period and following it, the researcher attempted to refine and reduce collected data to a more manageable dimension. Miles and Huberman (1984) share:

Outlines, reporting formats, and displays are all data-reductive devices for getting hundreds of pages of text down to workable units--three to four pages of text and some summarizing tables or figures ( $p .152$ ).

\section{RESEARCH TIME LINE}

Figure 3.3 illustrates the research time line of this study. The formal data collection perlod began in January 1987. The researcher continued to collect data to the end of the subjects' klndergarten contact with the word processing center in the Writing Lab, June 1987. Data analysis began with the first day he wrote a summary report and continued 
through the data collection period and into the final chapters of this dissertation. 
CHAPTER IV

PRESENTATION AND ANALYSIS OF DATA

\author{
INTRODUCTION
}

Scenario

in $30^{I}$ am gunnoo be a morshin

It was the first of October in the United States and Andrew, age 6 , had been thinking about his subject for the past few days. Although he may have been thinking about this subject for several weeks, he had been working on this particular text for only a few minutes. As one can see, he knows many English letter sound conventions. This is even evident in his inventive spellings of "gunnoo" and "morshin."

Now, Andy and his buddy Scott stood before the computer monitor thoughfully eyeing the sentence. After a moment, Andy turned to Scott and said "No, I don't mean the number 30, I want the word thirty." Andy quickly made two backspace key strokes resulting in the erasure of the numeral 30 , and then waited. Scott looked at Andy, then at the computer screen, and a moment later slowly began to type. By the time Scott finished writing the word "thrte," Andy was ready to contlnue writing and quickly followed with the word "days" and a perlod. Familiar with writing his entire name, Andrew proceeded to talk himself through all its letters. His sentence now read:

I am gunno be a morshin in thrte days.Andrew peter $M \subset D o n a 1 d-M 111 \in$

All of this was written across the top line of the word processing screen. Next, at Andy's request, Scott added the date to his story. Andy asked scott to write the date, "... because you can write it faster than me." As Scott began to wrlte the word October. Andy told him that he could write the date in numbers. When finished, Scott backspaced a few times, erasing part of the date and telling Andrew that the numbers were too far apart. Scott then rewrote the date's numerals as Andy talked to him about using a different punctuation mark to separate the numbers. 
Though It was Andrew's Idea, both boys were involved in this pre-Halloween story. Andy had begun with his thought of writing about $h$ is Halloween costume plans. Although it was still thirty days away, Andy was planning on being a Martian. His friend Scott, Initially looking over his shoulder and reading the computer screer, now knew all about Andy's plans. A few moments earlier, Scott, Andy's long time buddy, had walked by the word processing center and stopped to chat. since then, there had been continual chatter and sharing of ideas between the boys. Their discussion included the idea that a number could be written in both numeral and word form. Andy appreciated Scott's writing the numeral 30 but was guick to tell his buddy that he wanted the "... word thirty, not the number 30." Both boys re-read Andrew's text. Then Scott wrote the word "thrte" using his understanding of Engl ish letter-sound conventions. Scott and Andy continued to think about, discuss and share ideas as they collaborated on the date. Once completed, Andrew's text appeared as follows:

$$
\text { I am ounno be a morshin }
$$

in thrte days. Andrew peter $M=D o n a l d-M i l l e r$

october 1 , 1986

\section{Explanation}

Conversations, similar to the above scenario, were observed to be a regular part of the word processor environment while conducting this research. In this scenario, the publicness of computer technology was demonstrated as Scott read over Andrew's shoulder. In addition, both boys exhibited a sense of collaboration as they worked together and discussed certain print literacy conventions such as the proper spacing between the date's numerals. Their conversation, sharing behaviors, and actions also illustrate the ease with which one can manipulate this tool. After Andy erased the numeral 30, he turned to Scott and requested the "WORD" thirty. These behaviors and actions 
are but a sample of those revealed as I refined and analyzed data collected during this investigation.

This scenario was recorded on video tape during my preliminary research, nine months and a sumner vacation after Scott and Andrew began to use a word processor in Kindergarten. Scott entered school as what educators typically refer to as a "reader," while Andrew was considered a "non-reader." Part of the story of how these two boys evolved to passess the abllitles they exhlbit in this scenario can be understood through the presentation and. analysis of data collected during my formal research of $f$ ive subjects.

Following this scenarlo, Chapter IV contains a section which delineates the period of data collection. Next, a restatement of the study questions is followed by the flndings. These flndlings are separated into four sections. The first section presents quantitative data related to questions 1 and $1 \mathrm{a}$. This is followed by qualltative data, and a description of its analysis, as it relates to questions 1 and $1 \mathrm{a}$. The third section presents data associated with questions $1 \mathrm{~b}$ and 2. Additional findings are presented in the final section.

\section{Data Collection}

The data collection perlod of the formal research component to this study covered five months. Displayed in 
Table I are a variety of time forms representing this time span. Consisting of attempts at daily observations, this time span extended over a 20 week perlod. Due to holldays, school programs and other job-related responsibllities, observations occurred every four of five school days. During the flve months, the actual number of abservational days was 80. Daily observational periods lasted an hour, from 10 to 11 in the morning. These hourly sessions were followed by one half hour of data transfer activities and writing entries into the journals 1 isted in Table I. Total number of observation hours was 80 .

During these 80 hours of observation, I employed the various recording forms previously 1 llustrated and explained in Chapter III. In addition to recording behaviors on the "Daily Case Study Data Collection Form," displayed in Figure 3.7, concomitant anecdotal recordings of students' behaviors were completed. The minimum use of the "Dally Case Study Data Collection Form" was once per observation hour. However, If an observed subject's Invalvement with the word processor learning center was less than $20 \mathrm{mlnutes,} \mathrm{it} \mathrm{was}$ possible to abserve another subject that same hour using this same recording form. If it was not possible to record more than one subject in a hour with the "Daily Case Study Data Collection Form," the other subjects' word processor Invalvement was always recorded on the "Dally Case Study Group Data Collection Form," displayed in Figure 3.6. 
Subjects' written documents were always saved, both on a file disk and a printed hard copy. This occurred whether or not a subject had been observed that day using the "Dally Case Study Data Collection Form."

Following each observational session, comnitted time, use of printer, and choice of computer data were immediately transferred to data analyzing forms. Examples of these analyzing instruments are contained in Appendix B. At the end of each week, all recorded items from the various collection forms were transferred to corresponding computer data bases. After a few weeks of inputting data and upon examination of these data bases, certain patterns and trends began to appear. Following the data collection period, additional data bases were created as the collected data were analyzed. Further explanation concerning the collapsing and analyzlng of qualitative data is contained in the section titled: "Qualitative Research Analysls of Questions." Presentation and clarification of these patterns and trends and analysis of the data follow. 


\section{TABLE I}

\section{DURATION OF DATA COLLECTION PERIOD AND \\ DISK MEMORY STORAGE FOR \\ ANECDOTAL JOURNALS}

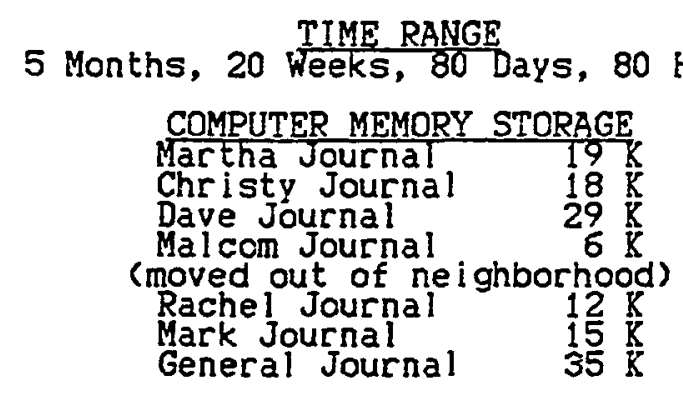

Seven journals were created for this study, one for each subject plus a "General Journal." These were employed for recording anecdotes following each observatlonal period. These entries were generally elaborations of collected data and the investigator's perceived insights about subjects' behaviors. "General Journal" entries included observations of phenomenon of interest not included elsewhere. These anecdotal entrles often included incldents Involving non-subject students.

In light of the data collection period extending over 5 months, as displayed in Table I, two of these journals became lengthy. Since one subject was lost to the study during the second month, (his family moved out of the school's nelghborhood) only six journals had entries covering the entire data collection period. These six journals took up $128 \mathrm{~K}$ ( 131,072 ) bytes of memory space, almost all the 
allowable memory on a $51 / 4$ inch floppy disk. (Each $\mathrm{K}$ represents 1,024 bytes or characters of memory space.) This is approxlmately 32 typed single space pages. The memory size of these journals ranged from the $35 \mathrm{~K}$ of the "General Journal" to the $12 \mathrm{~K}$ in the "Rachel Journal." All of this anecdotal journal data was in addition to the extensive amount of data collected during the 80 hour-long observation periods.

Scholars studying chlldrens' writing behaviors and associated tools of the Industrial Age (e.g. penclls, pens, and crayons) have employed certain terms to describe childrens' speclflc behavlors associated with these tools. Clay (1975), Graves (1983), and others refer to chlldrens' early use of a pencil or other writing implement as scribbling (Atkins, 1984; Baghban, 1984; Bissex, 1980). This behavior of scribbling carries the connotation of play and exploration. The computer, primary tool of the Information Age, does not possess inherent possibllitles for scribbling. However, computer systems possess the potentlal for play and exploration. Throughout this study, play and exploration behavlors associated with a computer are termed "Gobbledygook." In this study, other terms used to descrlbe more sophisticated writing behaviors correspond to those employed by scholars and researchers studying chlldrens' written language behaviors assoclated with Industrial Age writing tools, l.e. "copylng" and "writirg." 
During this study it was found that children often employed language and technology behaviors other than those directly associated with wrlting. A term employed throughout this study to describe these behaviors is "Dilly-Dallying." As explained later in this chapter, many language and technology behaviors were grouped into a category termed "Dilly-Dallying."

During the process of analysis, all data were read many times and color coded according to specific behavior categories. Throughout these processes of recording and analyzing data, the research focus was always that of the study statement.

\section{STUDY STATEMENT}

If given the opportunlty, how wlll chlldren use word processing in their print literacy development during their Kindergarten experience?

\section{Questions}

1. What developmental sequences related to print literacy reveal themselves as kindergarten children use a word processor?

1a. In what ways are these sequences the same as or different from those identified by researchers studying young children's use of pencil and paper? 
1b. What type of time commitments do children make at each stage of these developmental sequences?

2. How do the physical attributes of the computer environment influence children's behavior associated with word processing? For example: screen color or computer lacation.

\section{PRESENTATION AND ANALYSIS OF DATA}

\section{Question - 1}

What developmental sequences related to print literacy reveal themselves as kindergarten children use a word processor?

I found the children associated with this research to exhibit print literacy behaviors. When data was analyzed and placed in specific categories, certain patterns or sequences emerge, but not clear developmental stages. The evolving print literacy behaviors exhibited by students during this research are represented in Figure 4.1 . 
Gabol edygook

Play

Explore

Copying

Name

Alphabet, numbers

words, groups of words

Writing

Name

सiords

Phrases

Sentences

Stories, letters

Fiqure 4.1 Behavioral sequences of print literacy using a word processor.

There are three behavioral areas represented in Figure 4.1. The first area titled "Gobbledygook" refers to the play and exploration behaviors often observed as children used a word processor. At times it was obvious that children were playing as they wrote a batch of letters, numbers, or other keyboard signs. There were other occasions of exploration when a child would first write a word in capitals and then repeat it in lower case letters. There were many times when play and exploration were indistingulshable, e.g., with a friend, copying from a book and giggling over their writing the word "toilet," then trying to think of how to write similar "potty" type words.

"Copying" behavior was obvious. Copying the alphabet and the numbers 1 through 9 from a wall chart was an early "copying" behavior for many students. Others I gnored the alphabet and instead copied words and short phrases from their surroundings. Children would copy letters or words from books, posters, wall charts, word card labels, or 
dangling mobiles. With time, "copying" behavior products evolved into 1 ists of words.

"Wrlting" behaviors were often inltially abserved to be a component of "copying" behaviors. Generally, the first word whlch children wrote was their name. This was often followed by names of family members as well as assigned words from the IBM "Writing To Read" program. Once children were able to write a few words, their next attempts were at writing sentences and storles. See Figure 4.3 and Appendix C. As I daily recorded the types of writing behaviors, they appeared to form an evolutionary progression. An example of such a progression is lllustrated in Figure 4.2 . 
$1 / 22 / 87$

Martha Fish $f$ ish candycane

gfgrtutdffgteytdyueyewyufgfcbhwsy fgdugjdj jvjcjsf dhufh fh thhhyugghgjgj jduue hioi ballet

ghunyy fhsi uhhsueu; $y$; u i huuhh i i eowiwi tu tuuheh 76 i9

op8op i kruuhgj jusuhut jhugyghyguhuhuhgjhfjj fdjdjrjtui jhj i j i hj; j ; hj i jothghdu ckulk lbmcvvxxaxwxewxendld;'fm; [ ] t l=eddl, bknjljl;-jejnvcnbb-bxvikmg.284-3 105jgbngjy7ucghjkkkkkkokko7009909iji jokbbv (and more gobbledygookj

$2 / 20 / 87$

$\begin{array}{llll}\text { Martha ESHELL } & \text { COMPUTER } & \text { THREE } & \text { ABCDEFGHI JKLMNOPQRSTUVWXYZ } \\ \text { VASE } & \text { BIUE } & \text { RED } & \text { RABBIT } \\ \text { ENTER } & \text { SHIET } & \text { ESC } & \text { USA }\end{array}$

$3 / 16 / 87$

KIT COMPUTER THRRR

MOON

YARD

EISH

Martha

this is a man the man is on the box the man is woch the man the

$4 / 10 / 87$

THE RABBIT IS ON THE BOX THE RABBIT IS WOACH THE DOG THE END

$4 / 16 / 87$

Martha dog cat $f i s h$ in box fox

$5 / 6 / 87$

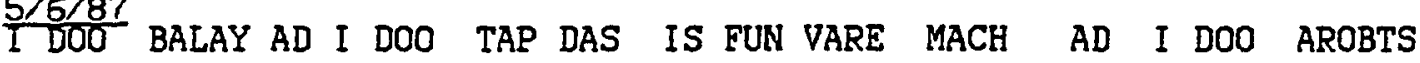

$5 / 18 / 87$

to my fad you will git tow cam to my houa san tam i hop you wano kam to my hous iole hav one bike to Tor I Martha

translation: To my friend, you will get to come to my house some time. I hope you want to come to my house. I only have one bike. To Tor $i$. Martha

Ficure 4.2 Selected samples of Martha's writing with a word processor. January through June 1987, illustrating her print i iteracy development. 
File: Martha Lit Data Report: Analysis

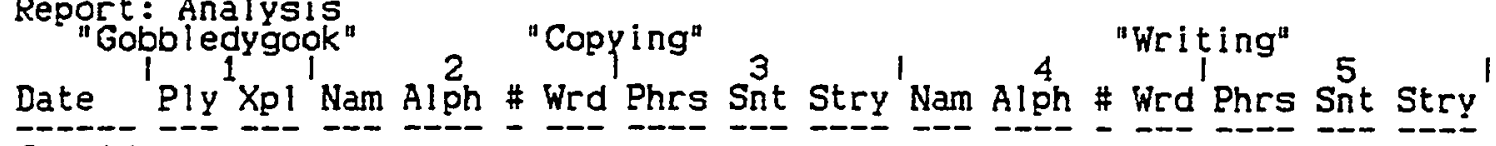

ta

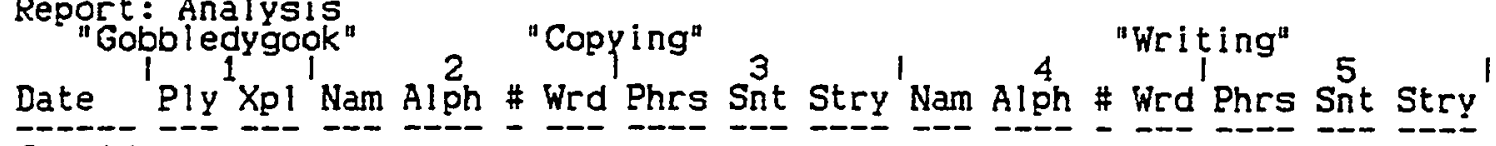

Page 1

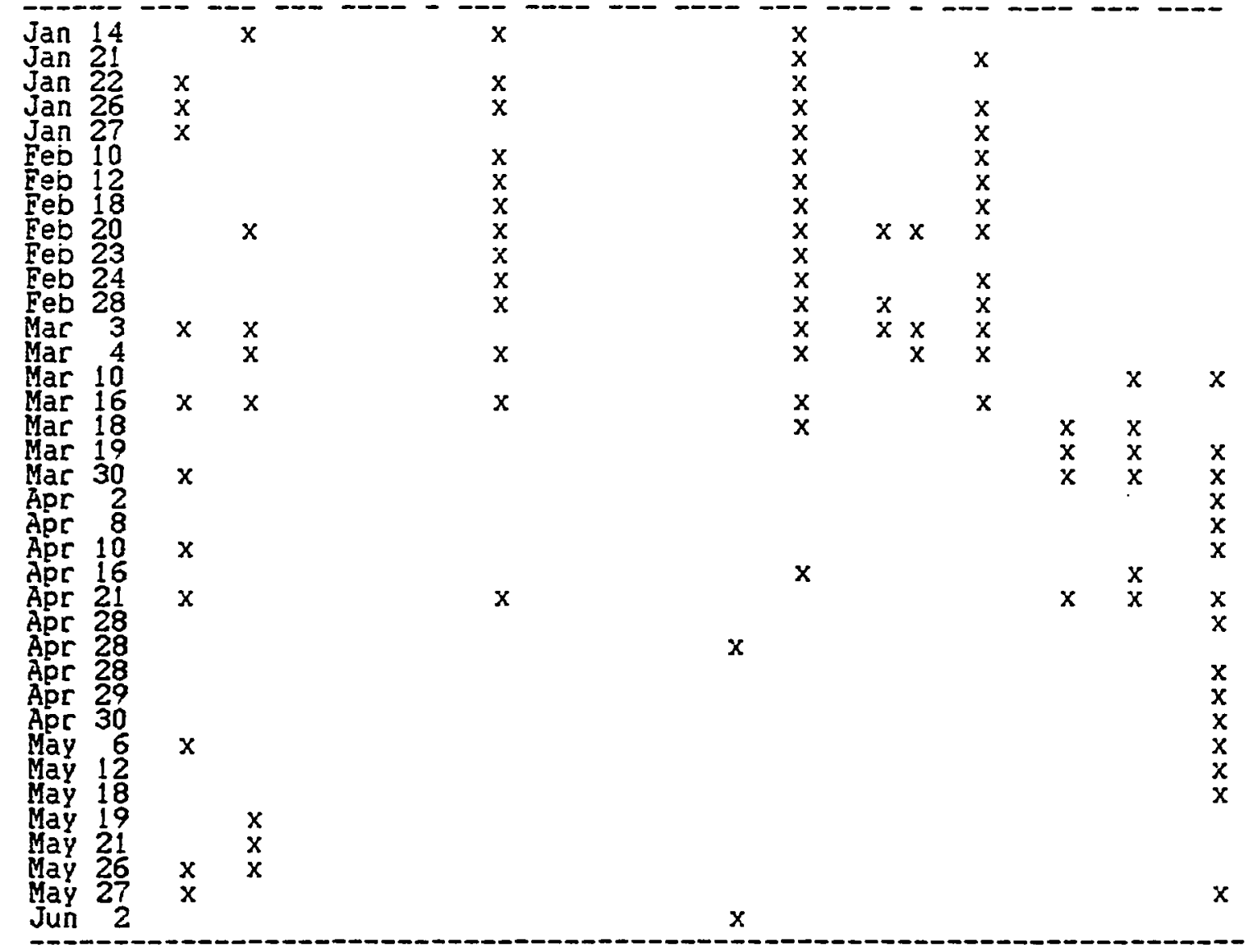

Floure 4.3 Data base of Martha's Literacy Development Chart showing her print literacy growth during the study.

Generally, these behavlors were observed to be intertwined as children progressed along their print literacy cont inuums. As Illustrated in Figure 4.3, Martha initially copled words and wrote her name and words whlle exploring and playing with text and tool. Within the first two months of my research. I observed Martha evolve to the point of writing storles. Martha's development is a continual cycling through 
gobbledygook, copying, and writing. Although she became more sophistlcated in her print literacy behaviors, Martha often returned to playing and exploring. Examin Figure 4.2, Martha's text for $4 / 16 / 87$. Even though she is capable of writing a phrase or story, she chose that Thursday to simply write words. Similar continuous cycling can be seen in other subject's literacy development data bases (Appendix C) and in Table II.

Table II is a composite chart representing collapsed data from the subjects' 1 lteracy development data bases exhlbited in Appendix C. The top of Figure 4.3, Martha's "Llt Data", displays the number code for collapsing data from subjects' literacy data bases to create Table II. The key at the bottom of Table II shows that any play or exploration behavlors are collapsed together and represented by number 1 . Copyling behaviors are represented by two numbers, 2 for copy behaviors; name, number, alphabet, and words, 3 for copy behaviors; phrase, sentence, and story. Writing behaviors are also represented by two numbers, 4 for writing behaviors; name, number, alphabet, and words, 5 for writing behaviors; phrase, sentence, and story. The column labeled week refers to a speclfic week of the study and can be correlated to the study calendar, Appendix L. In reference to subject columns, numbers in a chart cell represent those behaviors exhibited by an indlvidual subject during that speclfic week. 
Table II displays this continuous cycling of print literacy behaviors. Analysis of Martha's column, speclfically weeks 10 and beyond, displays her movement among a combination of behaviors. By the 10th week, she has achieved the sophistication of story writing, but continues to delve into earlier print literacy behaviors. Even though she has the ability to write stories, she continues to explore and play with written language. Dave's and Mark's columns illustrate the most prominent examples of this continuous cycling movement from mature to immature and back to mature print literacy behaviors. Both boys develop written language sophistication, achieving story writing skills, but continue to play and explore written language. As with Martha, although their print literacy continues to mature, both Dave and Mark exhibit a tendency to cycle back to less sophisticated literacy activities after week 10 . 
TABLE II

INDIVIDUAL LITERACY DEVELOPMENT CHARTS DATA COLLAPSED INTO FIVE CATEGORIES*

\begin{tabular}{|c|c|c|c|c|c|}
\hline \multirow{2}{*}{$\underset{1}{\text { Week }}$} & Martha & Christy & Dave & \multirow{2}{*}{$\begin{array}{c}\text { Rachel } \\
24\end{array}$} & \multirow{2}{*}{$\begin{array}{l}\text { Mark } \\
124\end{array}$} \\
\hline & 124 & 1 & 124 & & \\
\hline 2 & 124 & 124 & 14 & 24 & 1 \\
\hline 3 Februaru & 124 & 124 & 124 & & 24 \\
\hline 4 & & & 124 & 24 & 1 \\
\hline 5 & 24 & 124 & 24 & 24 & 124 \\
\hline 6 & 124 & 124 & 24 & 24 & 24 \\
\hline 7 & 24 & 24 & 24 & 24 & 24 \\
\hline $8^{1 / 20}$ & 124 & & 24 & 24 & \\
\hline 9 & $5 c$ & 124 & $5 c$ & 24 & 24 \\
\hline 10 & 1245 & 124 & 124 & 24 & 124 \\
\hline $11^{\text {Apt } 11}$ & 15 & 24 & 125 & $245 a, b$ & $245 a$ \\
\hline 12 & 15 & 124 & 5 & 34 & $45 a$ \\
\hline 13 & 45 & 124 & & 5 & $15 a$ \\
\hline 14 & 125 & 124 & 5 & & $25 a$ \\
\hline $15^{\ln d y}$ & 35 & $1245 a$ & 5 & 45 & \\
\hline 16 & 1 & $5 a$ & 1245 & & $15 a$ \\
\hline 17 & 5 & & 14 & 5 & 24 \\
\hline 18 & 1 & $5 a$ & 1 & 45 & 12 \\
\hline 19 & 1 & & 124 & & 124 \\
\hline 20 June & 3 & & 13 & 245 & 134 \\
\hline $\begin{array}{l}{ }^{*} 1-\text { play } \\
2-\text { copyir } \\
3 \text { - copyir } \\
4 \text { - writir } \\
5-\text { wrltir }\end{array}$ & $\begin{array}{l}\text { \&, explc } \\
\text { ng, name } \\
\text { ng, phr } \\
\text { ng, nam } \\
\text { ng, phr }\end{array}$ & $\begin{array}{l}\text { ente } \\
\text { ber, }\end{array}$ & $\begin{array}{l}\text { et, } \\
\text { :ory } \\
\text { oet, } \\
\text { ory }\end{array}$ & 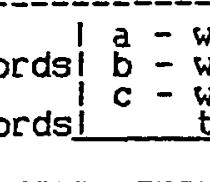 & $\begin{array}{l}\text { th adult } \\
\text { th peer } \\
\text { ote letter } \\
\text { friend }\end{array}$ \\
\hline
\end{tabular}

Also illustrated in Table II are what appear to be individual subject episodes of print literacy evolution. The collapsed data displayed in each subject's column depict subjects' Individual trends in their print literacy 
development. For example, Martha's literacy development chart, Figure 4.3, Appendix $C$, and the Martha column in Table II, illustrate that within weeks 8 to 10 she exhibited a more sophisticated use and understanding of print literacy when she began to write stories. Data displayed in Table II illustrate similar individual subject episodes of print literacy growth for other subjects, but at different time periods. Of particular interest is the apparent difference in growth patterns among subjects. While all subjects moved toward a more mature understanding of print literacy, they did it in different sequences. Another observed difference is that two of the subjects appear to have four individual subject episodes of print literacy evolution during this period of study while three subjects possess only two. Dave and Mark, the oldest subjects in the study, are the two with four natural print literacy eplsodes.

Figure 4.4 displays a variety of skills and behaviors termed "Dllly-Dallying" which were commonly exhibited by subjects in the word processor learning center. These skills and behaviors were often observed in conjunction with writing and using a word processor. 
Speaking

Listening

Reading

Letters \& Numbers

Control Keys, i.e., shift key, return, caps lock

Procedures, l.e.. print, clear, save

Formating, i.e., displaying the text

Sharling, l.e., exchange of information, print and tech.

Figure 4.4 "Dilly-Dallying" - examples of skills, behaviors, and understandings of print literacy and literacy of technology.

Children functionally employed these skills as they progressed along thelr literacy continuums. While writing, children were often observed to reread what they had written or read what they were copying. Many times, children would speak to themselves, breaking words into phonetic comporents attempting to determine which letter or letters corresponded to which sound. (The writing lab contained three IBM PCJrs. booted with CAI phonetics software which all students worked with each week. See Chapter III for description of WTR setting.) Students also requested assistance from peers and adults, listening to explanations and becoming involved in further discussion as they worked with sounds, letters, and words. The following entry is taken from my "Rachel Journal" notes.

$3 / 30 / 87$ Monday

It was interesting to observe Rachel today. She copled the cycle words [IBM Writing To Read words] with the assistance of Torl standing there telling Rachel the letters. I think she must have chatted a little more with Toril, ] as Tori sat down[,] about what should she do next. Anyway, the idea of a sentence came up and Tori told her she would help her figure out how to do it. Tori asked for a minute (to think about what to write) which she sald wasn't really very long and then suddenly said I've got it. Tor $i$ then told Rachel the sentence which Rachel then wrote as Torl told her what to write and how to spell the words. Once finished, 
Torl went over to Brenda [Classroom teacher] and told her that Rachel had written a sentence. Brenda really reinforced this and told her how good it was of her to write a sentence instead of her usual "emma and Rachel." Rachel then went ahead and copied a couple of wall and hanging words and then added cat. She next asked Tori which WP she was at and worked out that she was at number one. She then printed it herself.

In addition to the intertwining of print literacy behavlors, literacy of technology skills were intertwined with subjects' print literacy maturation. Early in this study it became obvious that literacy of technology associated with the print literacy tool (the word processor), was important to the print literacy process. In order for children's writing skills to progress, they require a functional awareness or understanding of the technology they are using. As with pencil, pen, and paper, it is an evolving prerequisite that children know how to manipulate their print literacy tool. An example of a chlld's literacy of technology skill awareness or understanding is use of space. I observed that before children could write an Intelligible word or two in a conventional sense with a word processor, they had to understand where to put spaces as well as how to control the tool in order to place spaces in desired locations.

Question - 1a

In what ways are these sequences the same as or different from those Identifled by researchers studying young children's use of pencil and paper? 
Although I conducted an extensive review of "early" literacy and wrlting I lterature, as explained in Chapter II, a universal chart displaying chlldren's typlcal developmental sequence of writing behaviors was not found. Many of the bibliographic citations associated with this literature review included discussion related to children's writing development. Figure 4.5 contains a modified version of Eigure 2.2 which is a composite based upon this 1 iterature review and what appears to be the developmental and evolutionary sequence or process of children's writing behaviors when using traditional literacy tools.

1 - Scribbles

2. Scribbles \& pictures

3. Cop Y (name, alphabet, numbers, words)

4. Name (write own name)

5. word

(inventive recognizable word)

initial y without vowels

later with vowels

5. Wor d Group

P - Serterie

8. Story or more sentences)

P. Punctuated Story

(story with appropriate punctuation)

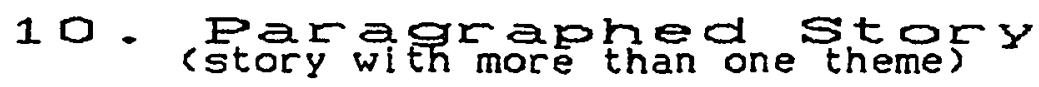

Figure 4.5 Writing behaviors of children A composite of varlous authorlties and my interpretation of behaviors assoclated with the evolution of people's writing in a print laden-society. 
Figure 4.6 is a composite of modified Figures 4.1 and 4.5. This Figure displays written language development for both the pen or pencil and paper system and the word processor system. Whereas the pen or pencil and paper system represents ten components, the word processor system represents three components. The lines in the middle of Eigure 4.6 illustrate the relationship of writing with the pen or pencil and paper system and the word processor system.

Figure 4.5

Pen or Pencil \& Paper System

1. Scribbles

2. Scribbles \& Pictures

3. Copy

4. Name

5. Word

6. Word Group

7. Sentence

8. Story

9. Punctuated Story

10. Paragraphed Story
Figure 4.1

Word Processor System

Gobbl edygook (play, explore)

Figure 4.5 Development of writing in children. Composite of Figures 4.1 and 4.5 displaying the interrelationship between the original systems.

It would have been possible to prepare Figure 4.1 in a linear fashion similar to that of Figure 4.5. However, as previously stated, there is an intertwined evolution between the tool and print literacy. Although subjects exhibited steady growth towards a more sophisticated literacy, this growth Included constant "Dilly-Dallylng" and continuous 
cycling back to earlier print literacy and literacy of technology skills and behaviors as illustrated in Table II. An example of this occurred two days before I recorded Martha writing her first story and the week after she had written a letter. My "Martha Journal" entry follows and Martha's corresponding text dated March 16 appears in Figure 4.7. $3 / 16 / 87$ Monday

Martha got into some exploration today with her moving her name around the screen by putting the cursor back at the beginning [of her document] using the arrow keys. This turned into play as she continued to mess with the word and her movement [of it] about the screen. After writing the word moon the same thing happened.

Also of interest, she was writing with lower case and then switched to upper case. She did this as she was copying one of the cycle words. She tried it first with upper case and then erased it. She next did it with lower case letters and then erased that. She finally settled with upper case and put the caps lock on.

The order on the screen is not the way she wrote. She began with her name, then went to yard and moon. She next went to the beginning [of her document] and wrote ["]kit["] and ["] computer thrre["] [moving everything to the rlght and down the screen]. She then finished with [wrote "]fish["] and ["] esc["] which the ["] esc["] she erased. [After copying the keyboard symbol "esc," she erased it.]

\section{KIT $16 / 87$ COMPUTER THRRR}

Figure 4.7 Martha's word processor written product for March 16, 1987.

This journal entry and Figure 4.7 ll lustrate that Martha appeared to discover that she could easily manlpulate text on her word processor screen and began to explore a varlety of 
possibilities. After writing her name and returning the cursor to the beginning of her document, Martha began to play with her writing space by moving her name about the word processor screen. She wrote additlonal words which she also moved about her text screen. Martha's play with words included her decision concerning which type of letters to use, upper or lower case. The ease of erasing a word or words is displayed here when Martha clears "esc" just after writing $1 \mathrm{t}$. She accomplished all of this textual manipulation and printed her document within ten minutes. Although Martha could have created a similar product using paper and pen or pencil, it would not have been done as quickly or cleanly. Also, using paper and pencll, she would not have the control to move text about the paper and easily change the textual format. Martha demonstrated in this ten minutes that she could write words but returned to "Gobbledygook" in order to "Dilly-Dally" wlth print literacy and literacy of technology.

Data displayed in Table II illustrate this constant movement between and among print 1 iteracy behaviors. Chlldren progressed towards a mature use of print literacy and literacy of technology, but often cycled back to, and "Dllly-Dallied" In, prevlaus less mature activities, skills, and behavlors. 


\title{
QUALITATIVE RESEARCH ANALYSIS AND
}

PRESENTATION OF QUESTIONS

\author{
Question - 1 \\ What developmental sequences related to print literacy \\ reveal themselves as kindergarten children use a word \\ processor? \\ Question - 1a. \\ In what ways are these sequences the same as or \\ dlfferent from those identified by researchers studying young \\ children's use of pencil and paper?
}

$$
\text { COLLAPSING, ANALYZING, AND PRESENTING }
$$

\section{Collapsing And Analyzing}

Throughout the periad of this study, I observed and recorded children integrating print literacy and literacy of technology skills and behaviors in their writing as well as their social interchanges with peers and adults. These behaviors and skills were recorded on the Daily Case Study Data Collection Form, in anecdotal notes, and in my general and subject journals. Once collected, this data had to be analyzed and arranged for presentation. In relation to qualitative data, Miles and Huberman (1984) offer this guldance :

1. We conslder that analysis conslsts of three concurrent flows of activity: data reductlon, data display, and conclusion drawing/verification ( $p .21$ ). 
2. Despite all this, we argue several times in this book that although words may be more unwieldy then numbers, they also enable 'thick description,' as Geertz (1973) suggests. That is, they render more meaning than numbers alone, and should be hung onto throughout data analysis (p. 54).

3. As yet there are no agreed-upon data set-ups among qualitative researchers, so each analyst has to invent his or her own (p. 79).

A recurring trend, the intertwining of print literacy and literacy of technology, continued to appear throughout this investigation. In order to conduct a claser analysis of this trend, I collapsed anecdotal notes, recorded during observations, into the following trend related categories: print, technology, mixed technologies, social, print social, and technology social. These categories are defined in Figure 4.8 .

Print - a form of print literacy, "Gobbledygook," "Copying," "Writing." Technology - use of the tool in a manner other than just Eyping letters or numbers.

Mixed Technologies - when both print and technological literacies were

Social - those litems not directly related to Print Social or Technology Social.

Print Soclal - Interaction related to print IIteracy between Individuals and among groups.

Technology Social - Interaction related to literacy of technology between individuals and among groups.

Figure 4.8 Definitions of qualitatively arranged and collapsed data categories.

Talking to oneself appeared to be another important behavlor as children worked with print at a word processor. This category is titled "Self Talk." Another important component titled "Date" was added to the data collapsing 
arrangement. "Date" references the data, it refers to the date data was recorded.

The next step in collapsing and arranging this qualitative data was selection of four colored highlighters: one color for each of the first three categories, plus one for all social behaviors. If self talk was present, it was marked with an $x$. Working on one subject's collected data at a time; I read through, analyzed, and coded all of the recorded data for each observation. Following the completion of this step, a text file was created with the categories arranged as follows:

Date Print: Technology:

Mix Literacles:

Social: Print Social: Tech Social: Self Talk:

(space for comments)

In order to accommodate remarks, a space was put at the bottom of each dated entry.

Once these data were collapsed and arranged in a manageable form, various figures were created. Manipulating data in such a manner allows for error through subjectlve interpretation although as one moves through the process of analysis one attempts to be as objective and study question focused as possible. In the future, computers, with artiflclal Intelligence, may help satisfy the concern for objectivity. One other polnt: a qualitative researcher may 
not realize the importance of something until the research is underway or has been completed, and therefore the recorded data may be incomplete for certain issues. The following presentation is a result of the afore described qualltative research process.

\section{Print Literacy}

Table III is a composite of each subject's frequency of involvement in the types of skills and behaviors described by the qualitative research techniques. Each column is labeled and represents one of the categories defined in Figure 4.8 . Illustrated in the left column "Print," and also on the Individually-compiled charts displayed in Appendix D, of all the recorded and analyzed opportunities to visit the word processor center, three of the subjects had $100 \%$ print literacy participation. All subjects were well above $90 \%$. Almost every time subjects were involved with a word processor they were doing something with print, "Gobbledygook," "Copying," or "Writing." In addition to Figure 4.2 , Figure 4.9 displays examples of subject products accepted for the "print literacy" category. 
$1 / 2 ? / 87$ Tuesday

dfhyy yhygu f fggddf sasasawsger iul op jhhggf $f$ dsderrreddgh $j 1$ l cbubvnmgfssasddf qw ertyuyyggghrtuyu i i i ugghcvgjoi 98 terrryuoyydfgink $1 ; 1$; I fff fdfgh jhk l zcvbvnnmkk

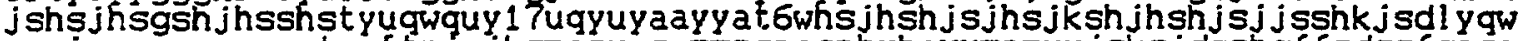
ueu i opopoproroptpp [ tnjsjksmnmx, s, mnzsngcnbvbcxxmnmxx jsksjdsshgf fsdssf gasa

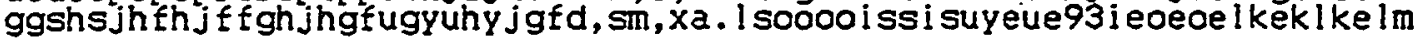

2/9/87 Monday

PIG SUi BED Rachel IEG MAN FISH STRAW dOG LEFT

$4 / 9 / 87$ Thursday

Rachel $i$ amgo to the pet shop i go to the to sdor

Fiqure 4.9 Examples of subjects' word processor products representing "Gobbledygook," "Copying," and "Writing." 
TABLE III

COMPOSITE OF COLLAPSED DATA DISPLAYING FREQUENCY

PERCENTAGE OF PRINT IITERACY AND LITERACY OF

TECHNOLOGY ASSOCIATED BEHAVIORS WITH EACH

OPPORTUNITY TO USE A WORD PROCESSOR

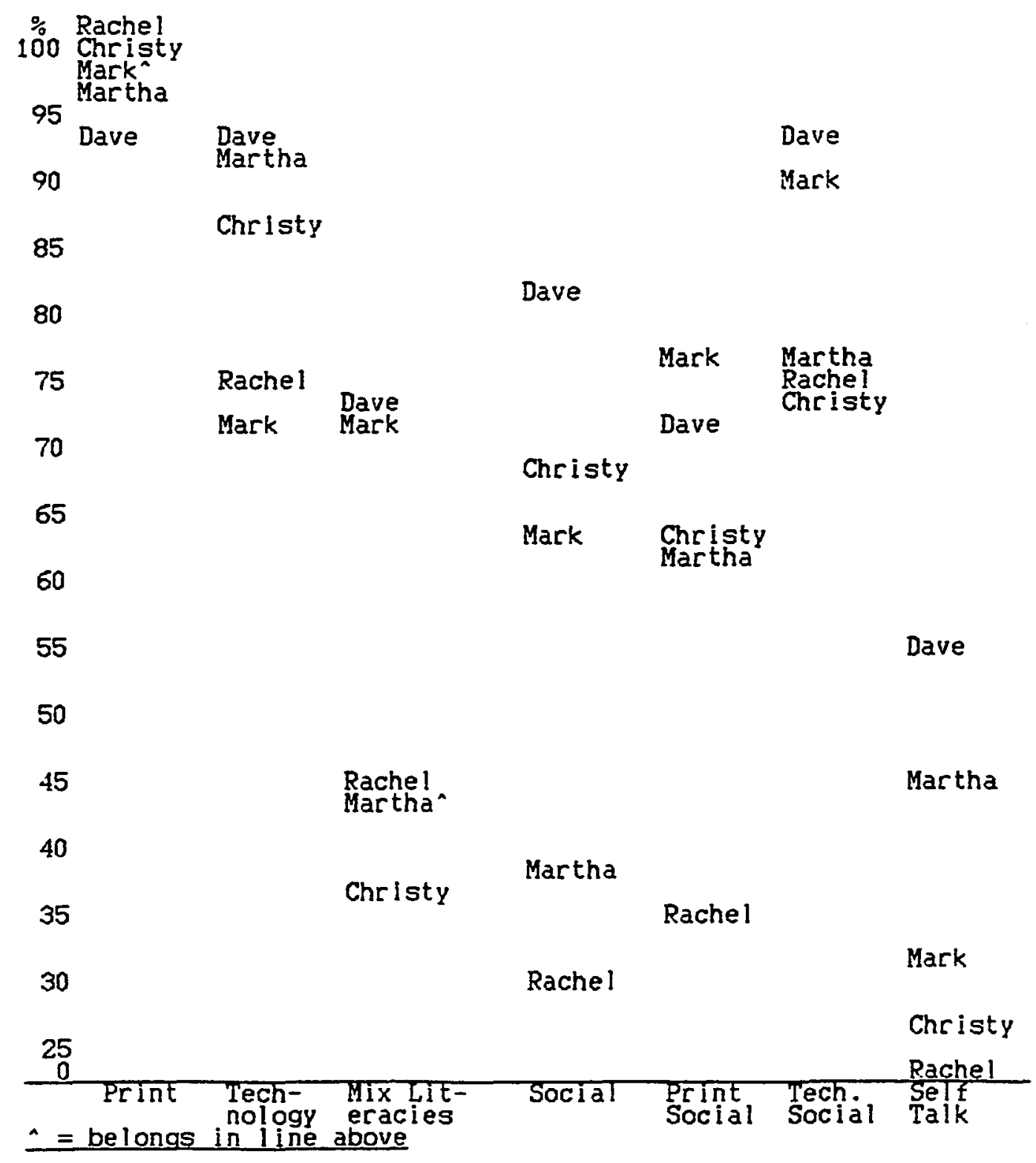




\section{Iiteracy of Tecinnology}

Regardling the second column of Table III, "Technology," all subjects displayed involvement in technology associated behaviors above the $70 \%$ level with three above $85 \%$. While at the word processor all subjects displayed behaviors associated with the tool, literacy of technology. A list of these behaviors includes:

- use of caps lock

- inputting spaces

- touching the screen

- attempted to determine why printer wouldn't output

- key rubbing

- play with space bar and backspace moving cursor

- play with return key

- movement of cursor, letters, or words about screen

- play type

- primitive keyboarding skills

- use of print screen keys instead of printing process

- save text

- retrieve text

- clearing text

- explorling the software, the edlt mode

Martha's text dated $3 / 16$ displayed in Figures 4.2 and 4.7 is typlcal of chllaren's manlpulation of the technology, their ability to move cursor and words around the screen. Subjects employed a variety of keyboard keys during their manipulating: arrow, backspace, delete, and enter. An entry In my "Christy Journal" offers another view of these behaviors.

$3 / 12 / 87$ Thursday

Christy was kind of exploring with the use of her space bar and backspace keys today. She had wrapped to the next line and then backspaced back to the previous line while erasing a word she was worklng on. Later she went on to wrlte some more words and letters and numbers and then 
backspaced and erased these Items when moving the cursor back to the previous line.

of the many technology behavions, two incorporated the physical act of touching. At different times during the study, all subjects were observed to touch the screen. This behavior coincided with their reviewing and rereading their text, appearing to try and touch their text. Key-rubbing was the other technology touching behavlor. It was noted that all subjects would rub their fingers back and forth across the keyboard at times. The following entry in my "Martha Journal" illustrates a typical journal entry recording this behavior.

\section{$4 / 21 / 87$ Tuesday}

Martha was assigned to come over to the WPs today and to write her cycle words and anything else she wanted to. She got started $r$ ight away banging out the letters as she copied her cycle words. Lots of swinging of legs as she went through this process. She also got to the word house and stayed with it for a bit, rubbing her $f$ ingers across the keys, apparently thinking about what she was doing. At one point she pushed too hard and then had to erase.

It was common to observe subjects rub their fingers across the keys. Key-rubbing was not an lsolated behavior. It was generally observed when subjects were intently involved in working on a word, a sentence, or a story; basically, at a time when they appeared deep in thought.

An additional physical phenomena of interest were subjects attempts at keyboarding. At times, subjects attempted to hold their fingers in a home-row-key fashion and try to type even though they had not been taught any 
keyboarding skills. They also tried alternating their typing from one hand to another. This consisted of first finding a desired letter on one side of the keyboard and pushing the key with a finger of the corresponding hand and then moving to the other side of the keyboard to find a desired letter and pushing the key with a finger of the corresponding hand. This keyboarding process was repeated until the word was written or the child lost interest. The following comments, two journal entries based on Martha's contact with a word processor, illustrate keyboarding behaviors.

$3 / 4 / 87$

Also, at one point when she was first copying the cycle words she had both hands poised over the keyboard appearing to want to use them in a touch typing type manner. She was interrupted by something else and when her attention was back to the keyboard she used just her $r$ ight or left hand.

$5 / 18 / 87$

She was pointing and touching the screen as she was reading when I arrived. She was using her right and then left hand looking for keys and talking to herself, saying the words and then also the sounds as she wrote. She constantly went back to reread her work, stopping and $f i g u r i n g$ out what she had written.

Martha's writing consisted of the talking to herself about the words she was using and the sounds in those words. Also rereading and going back over what she had already written.

\section{Mixed Literacies}

In comparison to the first two categorles of Table III, the subject's percentage levels in "Mixed Literacies"

Illustrates less invalvement. However, since it is not possible to directly observe a subject's cognitive pracesses, some of the behaviors attributed to the print literacy and 
literacy of technology categories may also be appropriate here. The types of behaviors associated with this category include:

- play with text

- format text

- hold shift key to print capitals

- use of caps lock

- erasure of misspel led words or not appropriate word

- use of space bar and arrow keys to go to next line

- touching screen as rereading

- inappropriate, for written language, use of keys and sof tware

- attempting to find appropriate print conventions

- rewriting words

Subjects were observed to manipulate their text in order to create speclfic formats which often resulted in their discovery of written English language conventions. Children commonly moved words along a text line inputting spaces of varying sizes between words. Some chlldren wrote their texts in columns, lining words up on one line with those in the line above. Their manipulations included moving the cursor back into their document, rewriting as necessary and then returning the cursor to the end of their document and continuing to write.

At $t$ imes, the mix of technologies had the potential of producing devastating results, possibly with lasting insight. The following two examples are copied from entries in my "Dave" and "General" journals whlch include some of the above category behavlors.

$4 / 29 / 87$ Wednesday

Dave had a good story going this morning. Spent a lot of time at the WP center which included getting up and 
helping others with their work. He wasn't all that focused but then got back to his work quite readily. When he finished he wrote THE AN and then space barred his way to the middle of the next line and wrote ["] Dave. ["] and then erased the period and added a comma and then his middle name. This was a first that I had seen this behavior and his attempt at punctuation.

Dave next went to print. Instead of printing from memory he followed the yellow card chand written To Clear instructions) on the book stand and proceeded to erase all of his work. He looked at his screen, said "What did I do?" then followed with an "Oh Nuts!" apparently knowing exactly what he had done. He turned to me and asked if there was anything I could do if it was some place where he could have it. I explalned no, that it was now cleared and that it was too bad, to think about writing it again tomorrow. His concern was that it had to be in today for the lloyd Center [Teacher Fair] display [this weekend].

\section{$4 / 29 / 87$ Wednesday}

After spending 35 minutes writing a story, Dave accidently cleared his screen instead of printing his stary. The idea that he is learning as a young child that this ephemeral light source is so easy to change is interesting. This is the same $k i d[$,$] who when the plug was pulled last$ week and everything crashed[, had] his come back. As adults we do these [lose texts] kinds of things and it adds a lot of stress. Dave as a young child is learning that this has occurred and that this time he was in control of the situation. I would think that this will impact him cognitively and affectively as far as his understanding and relationship to the use of technology. Kind of reminds me of swimming, if you pick up the sense of control and [have no] fear of water as a child then it's easy to continue as an adult instead of tryling to start as an adult.

The following entry from my "Martha Journal" illustrates her movement of text about the screen and her use of the caps lock function to explore upper and lower case alphabet

letters. As is apparent in this entry, there was a great deal of mixing print literacy and literacy of technology.

\section{$3 / 3 / 87$ Tuesday}

The WP's were busy this morning. Just after Rachel finished, Martha came over to me as I saved Rachel's work to ask if she could use that particular WP. I told her yes and she went ahead and began to work at it. 
After writing a few words, she put the cursor at the beginning of her text and then moved the words around the screen. At first this seemed to be an exploration on her point being interested in what was happening. After getting the first couple of words down to the next 1 ine it then appeared to become a playful activity. She continued to move the words further down the screen.

Next she wrote the alphabet. Initially the caps lock was on. Half way through the alphabet she took it off and began to write in lower case though once in a while she again wrote an upper case letter with the shlft key.

When finished she moved the words a few lines lower on the screen and then wrote the word one. She next wrote some numerals and then erased them immediately. She then went ahead and printed her text.

This final journal entry exemplifying mixed literacies illustrates the publicness of this Information Age tool.. As an author writes with a word processor, others can easily look over thelr shoulder and read the document. Unless an author clears the document from the screen when leaving, text remains and is avallable for others to read. The following example of such behavior is taken from my "Martha Journal."

$4 / 29 / 87$ Wednesday

Two really interesting occurrences at school. The flrst involved a couple of different $k i d s$ as the WTR lab was clearing out and Martha was walking around the WP's getting ready to leave. She noticed one [monitor screen] and in a large excited voice yelled "Whose is that!" or "Who did that!" A couple of other $k i d s$ who were still remalning in the room walked over to see what she had found. The kids had a short discussion about the work they had seen on the screen and then left to catch up with their class.

\section{Social Behaviors}

The next category represented in Table III, column

"Social," Incorporates those observed behaviors which dld not easily fit into the other two social categories. Some of these behaviors were: 
- chatting with peers about what I was doing

- telling other children what to do

- adults moving children out of word processor center

- "goof off" behaviors not related to print or technology but while at word processor center

- dialogue with others about none related topics

- adult dialogue concerning behavior

- sharing of information

There were many typical childhood behaviors occurring in the word processor center. One of note was an unwillingness by children to leave an activity where they found interest and enjoyment in order to particlpate in an assigned activity. This behavior was observed and documented in the word processor learning center when children were requested to stop what they were doing in order to work with CAI computers and learn written language through programmed phonics.

A refusal to comply with these directions was documented early in my "Mark Journal."

\section{$1 / 29 / 87$ Thursday}

Brenda asked Mark if he wanted to go to computer. He pointed to the word processors and said "Yes!" She pointed to the CAI computers and he declined.

Although this behavior was documented early durling the data collection period, it was not a majar concern of this study. However, there were other occurrences of similar avoidance behaviors acknowledged by other adults in the writing lab. The following entry from my "General Journal" occurred at the end of the data collection period. $6 / 2 / 87$ Tuesday

Two things from this morning. One was the meta-linguistics [exhibited by the students] whlch occurred 
over the thought of copying from a book [but not publishing it] and how to continue on [the next day] since it was time to go back to class. The other was Kathy mentioning that the kids really didn't want to go to the CAI computers and function with that software.

I think this issue of not wanting to work with the CAI software is a function of industrial Age thinking using Information Age technology. It's learning theory of the Industrial Age being used with the literacy technology of the Information Age. She [Kathy] said the kids are bored and just not interested in the CAI type of stuff that's going on. This is with those kids who are still in the cycles at this time of the year. They aren't doing fun stuff [personally meaningful] except with the WPs and on Friday when there are games. [As the data collection perlod continued, Kindergaten teachers decided to use literacy games with the CAI computers on Fridays.]

This requesting children to move occurred at other times also. It commonly interfered with a variety of behaviors which is Illustrated in the following entry from my "General Journal."

$2 / 12 / 87$ Thursday

The third activity was of particular interest. Martha and Sarah had gone to the WP's together and had sat near one another. Each began their own text file but both shared Information with one another. Sarah asked Martha a couple of times where certain keys were on the keyboard. Martha would give directional answers, "On the other side cof the keyboard) somewhere." Martha said she had forgotten how to spell a couple of the cycle two words and Sarah helped her with some of these. They were both working on "bed" for Martha and coming up with various endings, none of them correct[,] when Kathy came over to tell the girls that they were next at the CAI computers. Here the girls were[,] practlcing their literacy, trying out some phonemes and putting words together[,] but they had to leave their work, what they were in control of, in order to go to the CAI machlnes [whlch are] in control and learn something. Brings some questlons to mind.

I intend to share today's entry with Kathy and Brenda.

Noting Table II again, Rachel is the subject with the

lowest percentage of social print invalvement. Rachel's personality is such that she is very quiet and unassuming. 
The other chlldren involved in this study are much more extroverted in their behaviors.

Social Behaviors Related To Print Literacy

The fourth category displayed in Table III was used to codify those behaviors which were socially associated with print literacy, column "Print Social." This category included the following behaviors.

- chatting and sharing about sounds, words, and spellings

- chatting and sharing about language conventlons, e.g., punctuation, capitals,

- trying to figure out letter/sound conventions

- bragging about how much they knew

- chatting and sharing their stories and words as well as format of storles and topics

- wanting copies of other persons documents

- reading other's printed documents

- sharing text

- request adult confirmation on spellings

- meta-lingulstics, solving language conventions

There were many episodes of social interchange

concerning print 11 teracy during this study. From the very beginning of the data collection period, these behaviors were commonly observed in the word processor center. Chlldren were often involved in requesting or sharing information about language as when Sarah and Martha shared written language information with one another, recorded in my "General Journal" 2/12/87, previously noted. Meta-linguistics was not unique to these young evolving print 1 iterates. The $3 / 30 / 87$ from my "Rachel Journal" entry, a few pages back, and the following entry from my "Dave Journal" 
illustrate the interest and intensity of sharing knowledge and the occurrence of meta-linguistics.

$3 / 3 / 87$ Tuesday

There were a number of conversations between Dave and Jason this morning. A number of them initated by Jason as he would turn to Dave or myself and ask for the sound of a letter. Even when the question was directed to me, Dave would go ahead and answer. A couple of times this led to Dave getting out of his seat and chatting with Jason about the sounds in or actual spelling of a word. At one point he even sat down and wrote the word for him.

Except for an initial orientation session to the writing lab and its learning centers, adult-led direct group instruction was never observed. However, there were numerous dally print literate activities and associated instruction occurring within the various learning centers of the writing lab. Children continuously shared their knowiedge of print and technology with their peers and writing colleagues. In addition to children discovering and reinventing written language, adults helped to facilitate the children's intellectual growth. Generally, adults responded to a chlld's needs or anticipated $h i s / h e r$ next move along the print literacy and literacy of technology continuum. Often, after an adult shared a new print skill or computer opperation with one child, many others were exposed to it within a few days. Children became condults of information for their classmates. Adults and peers were facilitators for each student's literacy growth. The following entry in my "General Journal" Is an example of adult and peer sharing of 
an English language writing convention and illustrates

meta-lingulstics.

$2 / 10 / 87$ Tuesday

Christy spent a good 25 minutes with a WP today first doing as Brenda had requested, copying cycle words and then off playing and exploring. She did a lot of pushing keys and then erasing what she had done and then going back and pushing more keys. This wasn't done in a fast manner, but sitting there and watching [looking at the keys, monitor, and her own movements with the equipment, seeingl what she was doing [herself].

She got into a lot of words. She would play with the keys for a moment and then try to write a word. One word she knew was cat which is inbedded in her writing. She then began to think of other words which she asked various people how to spell. This included peers, Brenda and myself. As she was writing (her) paper, which she was trying to sound out with my help. Sarah noticed she hadn't left any spaces and wondered aloud to me whether she should. Sarah and I then talked about that generally when one writes that you do leave spaces. She told me that she did. Christy simply kept on with the process she had begun.

Social Behaviors Related To Literacy of Technology

Again, in reference to Table III, column "Tech. Social,"

over $70 \%$ of the time children attended the word processor

center they became involved in some form of social

interaction assoclated with literacy of technology. A great amount of social interchange was in the form of assisting

others or receiving assistance with the printing process. As children became self sufficient at printing and later, writing, their social interactions associated with technology moved towards sharing of information while exploring the word processor software. Many behavlors assoclated with this category are included in the followlng list. 
- chatting and sharing about writing in upper and lower case letters.

- chatting and sharing about the printing process and clearing the screen

- assistance in finding keys

- chatting and sharing about manipulation of cursor

- chatting and sharing about exploring and manipulation of harciware and software

- chatting about saving or printing text

- solving printer problems

Of the many journal entries written during the data

collection period which are associated with this category, two of significant interest follow. One concerns one-up-man-ship or peer squabbles. The other illustrates social etiquette of the Information Age. Both of these entries are taken from my "General Journal."

$2 / 26 / 87$ Thursday

An interesting situation occurred today with printing at the word processor center in the WTR (Writing Lab) room. One child went around the word processor center to turn the network switch so that she could print. As she headed back to her word processor [,] the child at the one next to the printer leaned over and turned the switch to the number for his word processor and began immediately to print. I noticed this and as I began to give my little speech about working together and asking others if the printer was free before printing, I noticed another child back at the first child's word processor erasing all of the text. I quickly walked over and after saying ["]stop["] explained that he should wait and ask the person who had been using it if they were done.

We now have children, seven weeks after gettling started with WTR (Writing To Read, word processors), who are computer literate to the polnt that they have a lot of knowledge about manipulating a ward processor and computer system. Suddenly, we are now at the point of also providing children with social skills related to the utllization of a word processor and the electronic text. Children don't generally erase other chlldren's paper work, but with a word processor [,] it's simple.

$5 / 7 / 87$ Thursday

Again today $[$,$] a lot of k i d s$ at the writing table and the WP center. Both centers were overflowing at times. 
An interesting situation today. Matthew and Dave got into a fight over who knew the most about computers. These two have at $t$ imes gone on a one upmanshlp before, but [this is] the first time it has come to blows. Both also have a little different style in their approach to the computers and exploration. With Dave it appears that he explores while involved in his writing or actual production. Matthew seems to focus right on exploring at times trying new things out with the software. Both appear to be very willing to share their findings with others.

As defined in the "Mixed Iiteracies" category of Table III, analysis comments related to Table II, and previous exampled entries $2 / 12 / 87,3 / 4 / 87,5 / 18 / 87$, and $6 / 2 / 87$, many of these literacy of technology behaviors were intertwined with those of print literacy. In the setting of the word processor center, there were many opportunities for dialogue and the sharing of thoughts about print and technology.

\section{Self Talk}

The final column of Table II is labeled "Self Talk." Collecting data assoclated with this behavior is one of those hazy areas of qualitative research. Difficulties encountered collecting related "Self Talk" data "in the word processor center were environmental noise, physically positioning myself without being too obtruslve, and not being sure if some of the subjects were speaking to themselves. In order to overcome these difficulties, I employed tape recorders during preliminary research. The resulting audio was of such poor quality that the tape recorders were abandoned. Of the subjects, Rachel was the most dlfflcult to record since she 
was so quiet. She may have spoken to herself but it was simply missed durling my observations.

The category "Self Talk" is defined as speaking to oneself. This behavior was commonly observed throughout the data collection period. Inltially this behavior centered on saying sounds and words as subjects developed their own print literacy skills. Eventually, this led to at least one subject reading the text from a book she was copying. The following two examples bridge this evolution in "Self Talk" behavior from sounding out words to reading a text. The first example is an entry from my "Dave Journal" while the second is an entry from my "Martha Journal."

$1 / 20 / 87$ Tuesday Though I didn't follow him from the beginning of his sitting at the WP, I was able to observe Dave for a good 15 minutes or so. It's difficult to read what he has written, but there is sense to all of his words. He continued to sound out each word, erased some that he wasn't satlsfied with and then went on and wrote more.

\section{$6 / 2 / 87$ Tuesday}

Martha came over with one of the Ladybird books and began to copy from the cover. She spoke to Hazel about the front[,] asking her what it said. She also asked me if one of the letters she was copying was an ["] ["]. Once finished with the front cover she turned to the first page and began to copy from the story. She did a lot of self-talk centered on the letters and words. As she went along with this format of reading the letters[,] it evolved into reading the words. She seemed to suddenly realize that she was able to read some of the text and did so. At one point she turned to me for confirmation on one of the sentences after she had already asked for confirmation on a couple of letters and the beginning word.

In summary, wrlting behavlors were not isolated but intertwined with many associated print literacy and literacy 
of technology skills. Also, meta-lingusitics was a common practice throughout the study, commonly intertwined in the dialogue and actions of subjects. Throughout the data collection period, each subject displayed a progressive maturation towards greater print 1 iteracy and $l$ iteracy of technology sophistication.

Question - 16

What type of time commitments do children make at each stage of these developmental sequences?

Qual itative research can be described as an extremely porous medium for collecting data. With practice, experience, and contextual knowledge, a researcher's ability to collect relevant data improves. This description reflects my experience during the data collection period of this study. It was not possible to record every single incident of a subject's involvement with a word processor. In addition to interruptions, which normally occurred, there were other recording lapses, particularly at the beginning of my investigation. I found that I had to learn how my subjects operated within the word processor learning center environment. I missed observing Rachel a few times in January due to her quietness; it was as though she sneaked into the center, quietly worked, and then left without a sound so I would not be able to record her actions. An 
example of my thoughts during this part of my study is included early in my "General Journal."

$2 / 2 / 87$ Monday

I don't know what it is, but Rachel got started without my being aware of it. She seems to sneak in and then after a few moments I notice that she is sitting there working away.

Another factor influencing the recorded time a subject spent with a word processor was that of center access. The subjects' class attended the writing lab for approximately one hour each day. In order for children to progress through the "Writing To Read" CAI cycles, the classroom teacher, Brenda, would at times have to assign children to different learning centers. As a result, even though children might want to work in the word processor center, they might not have the opportunity. The following paragraph, written early in my "General Journal," refers to this situation.

\section{$2 / 5 / 87$ Thursday}

Brenda has been doling a great job of directing children around the writing lab. Therefore, [because Brenda assigns them to specific learning centers other than the word processor center] they don't always get the opportunity to use or choose the word processors. At times their choice of the WP center comes at the end of the hour after they have been to the CAI computers and journal or some other centers where they haven't been for awhile. At other times they chose to go to other centers. Anyway, like today, most of the $\mathrm{kids}$ whom $I$ observe were assigned to other centers or in the CAI journal rotation.

At times, I observed subjects directed to other centers when they expressed a desire to work at the word processor center. The only time I observed subjects refuse an opportunity to work with a word processor was when they had an opportunity to take their "Writing To Read" CAI mastery 
test. Once they had finished the mastery test, they often requested an opportunity to return to the word processor center. Similar behaviors were observed in subjects when involved in other centers and summoned to take a CAI mastery test. Over time, I observed that the two most popular locations in the the writing lab appeared to be the writing and word processor centers. The following observation I recorded in my "General Journal."

$5 / 5 / 87$ Tuesday

I've noticed the past few days that we have had more kids working in the WP center than a month ago. The two big centers are the writing and the WP centers. Not as many into the chalk or books. Hazel has been spending more time in the WP center. This may have something to do with [it] or also the fact that there is a literacy maturation and it's easier for students to write now than it was a month ago.

Other than pupil absence, the only other outside variable which interfered with children's access to the Writing Lab were scheduled curriculum events. These conflicts are recorded on the school calendar. A copy of the school calendar, during the data collection period of this investigation, is Included in Appendix L.

Time data presented in this section relate directly to actual subject using word processor occurances. Writing sessions which were intercupted or interferred with by subjects being moved to another learning center or end of class perlad in the writing $l a b$ are excluded from this data. However, some of the writing sessions which continued for 
more than 30 minutes and were terminated by the end of the class period are included.

Time Related to Natural Literacy Evolution. Among other findings, Table II illustrates what appear to be Individual subject episodes of print 1 iteracy evolution. CSee earlier discussion concerning Table II and associated findings.) Tables IV and $V$ display the recorded amount of time i: minutes each subject dedicated to these episodes of literacy growth. Subjects are grouped in these figures according to the number of apparent episodes of print literacy evolution. 
TABLE IV

COMPILATION OF RECORDED TIME IN MINUTES RELATED TO

SUBJECT-SPEC:ZIC EPISODES OF PRINT LITERACY EVOLUTION DOCJMENTED IN TABLE II

FOR Martha, Christy,

AND Rachel

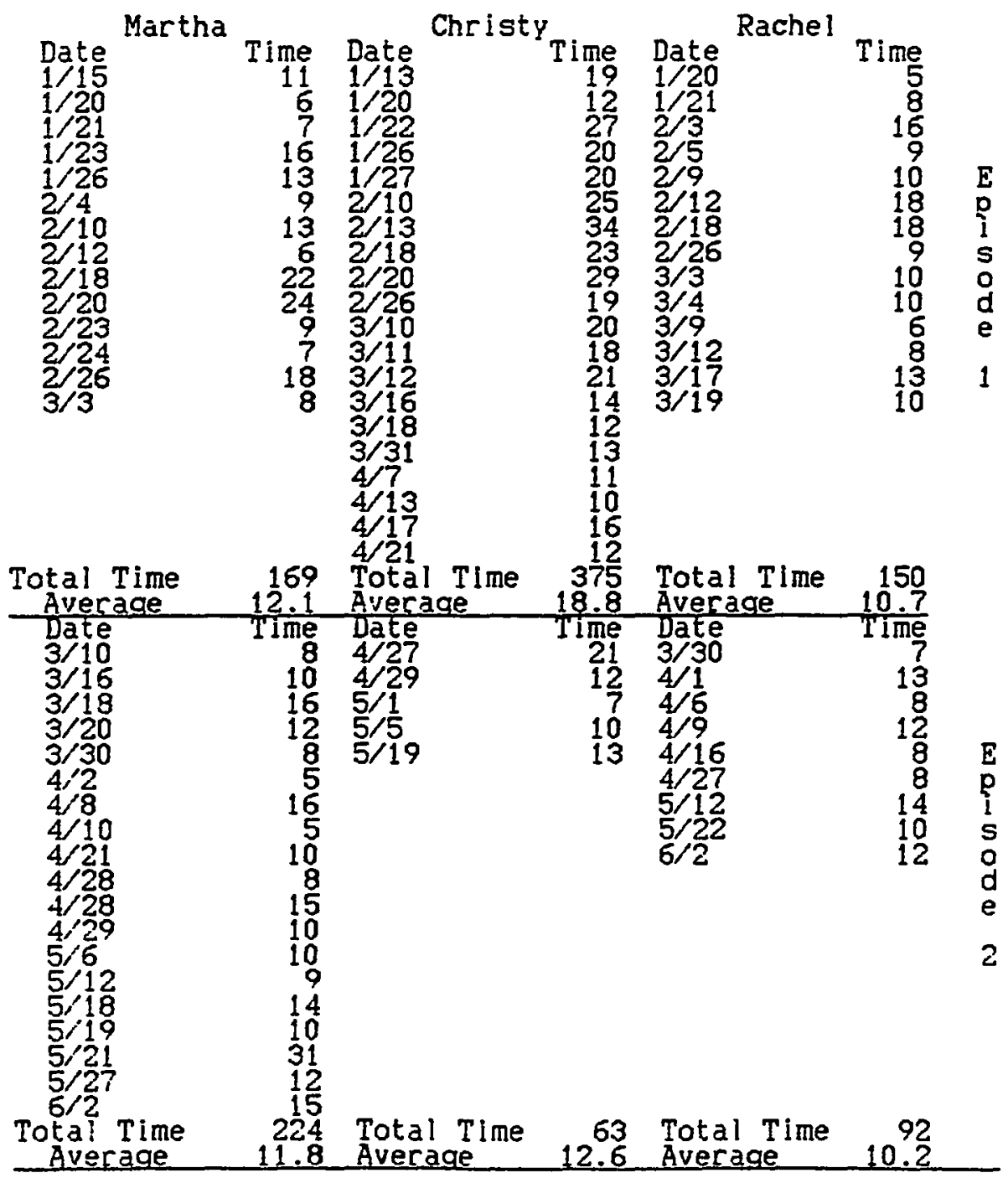


TABLE $V$
COMPILATION OF RECORDED TIME IN MINUTES RELATED TO SUBJECT-SPECIFIC EPISODES OE PRINT LITERACY EVOLUTION DOCUMENTED IN TABLE II FOR Dave AND Mark

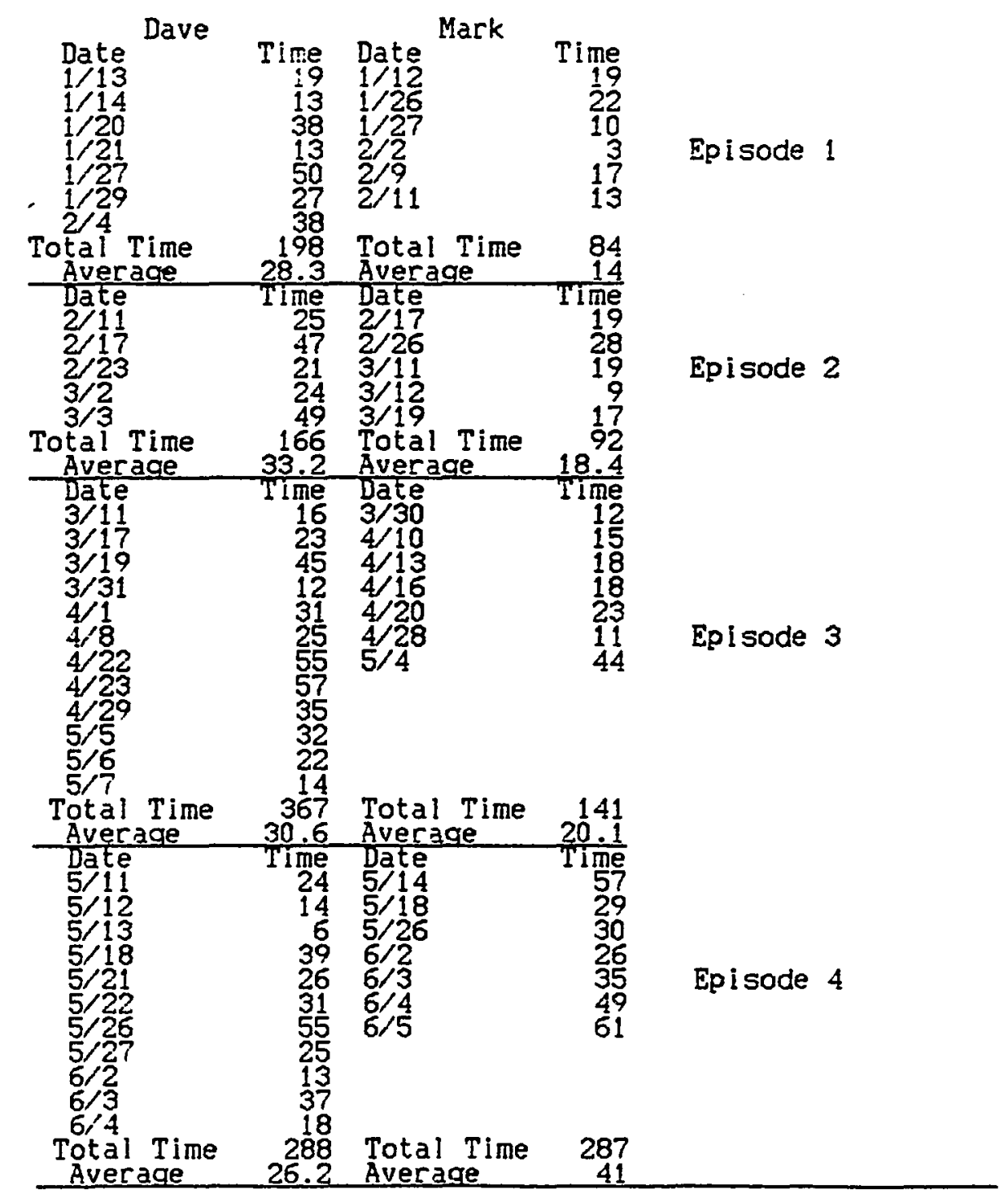

There are some major differences in the amount of time subjects spent in their individual print 1 iteracy episodes. Numbers displayed in Table IV, illustrate Chr lsty spending 
more than twice the amount of time moving to her second print 1 iteracy ep isode than either Martha or Rachel. Christy's per session time involvement at the word processor center is approximately a third more than the other two girls. As illustrated in Table II, Christy moved to a more mature understanding of literacy during week 15 when she began to write stories with adult assistance. Martha and Rachel, respectively, had consummated this move 4 and 6 weeks earlier. Both Martha and Rachel were writing stories without adult assistance during the ir second 1 iteracy progression segment. Although Christy had spent more than twice the amount of time in her initial print literacy episode, her writing skills were not as mature as Martha's and Rachel's once she began to write stories.

Through the girls' two print literacy episodes, ll lustrated in Table IV, the average amount of time per session is relatively similar for each subject. The only exception to this similarity is Chrlsty's average time commitment during her first episode. As the girls matured to a more sophisticated understanding of literacy, they spent about the same amount of time per session in each of their print literacy episodes. The exception again is Christy as her time per session decreases by about a thlrd during her second print 1 iteracy episode. Chrlsty did not partlcipate in the word processor center during the final two weeks of the study as indicated in Table II. 
A similar situation, illustrated in Table IV, exists when comparing Mark's and Dave's recorded involvement. Both Mark's and Dave's written 1 iteracy abilities continued to evolve throughout the period of data collection as illustrated in Table II. Through the first 16 weeks, Dave spent much more time with word processors than Mark. At each print literacy episode, Dave spent approximately twice as much total time and double the time per session as Mark. While Dave's time per session fluctuates within a range of approximately 25\% through all four print literacy episodes, Mark increases his time by almost a third through his third segment and triples it during his fourth segment.

Table $V$ illustrates that during their fourth and final print literacy episodes there was a difference of only one minute in the total amount of time that Mark and Dave dedicated to exploring, copying, and wrlting. However, there was a difference of 15 minutes between Dave's 26 minute average per session and Mark's 41 minutes. Dave was self sufficience in writing stories which could be interpreted as being more mature in his understanding of literacy. When Mark wrote a story, he still found it necessary to request adult or peer involvement and assistance. Even though there were these differences in time and maturation of literacy, both boys were involved in some of the same activities during their final print literacy episodes. 
Monthly Time Commitment. As previously explained, it was not possible to observe and record each subject's daily invalvement with the word processor. However, as displayed in Tables IV and $V$, except in June, during each month there were multiple abservation recording sessions for each child. Figure 4.10 displays an approximation of each subject's monthly average time commitment per session. As a result of school closing for summer break, during the month of June subjects had only one week to particlpate in the writing center. 


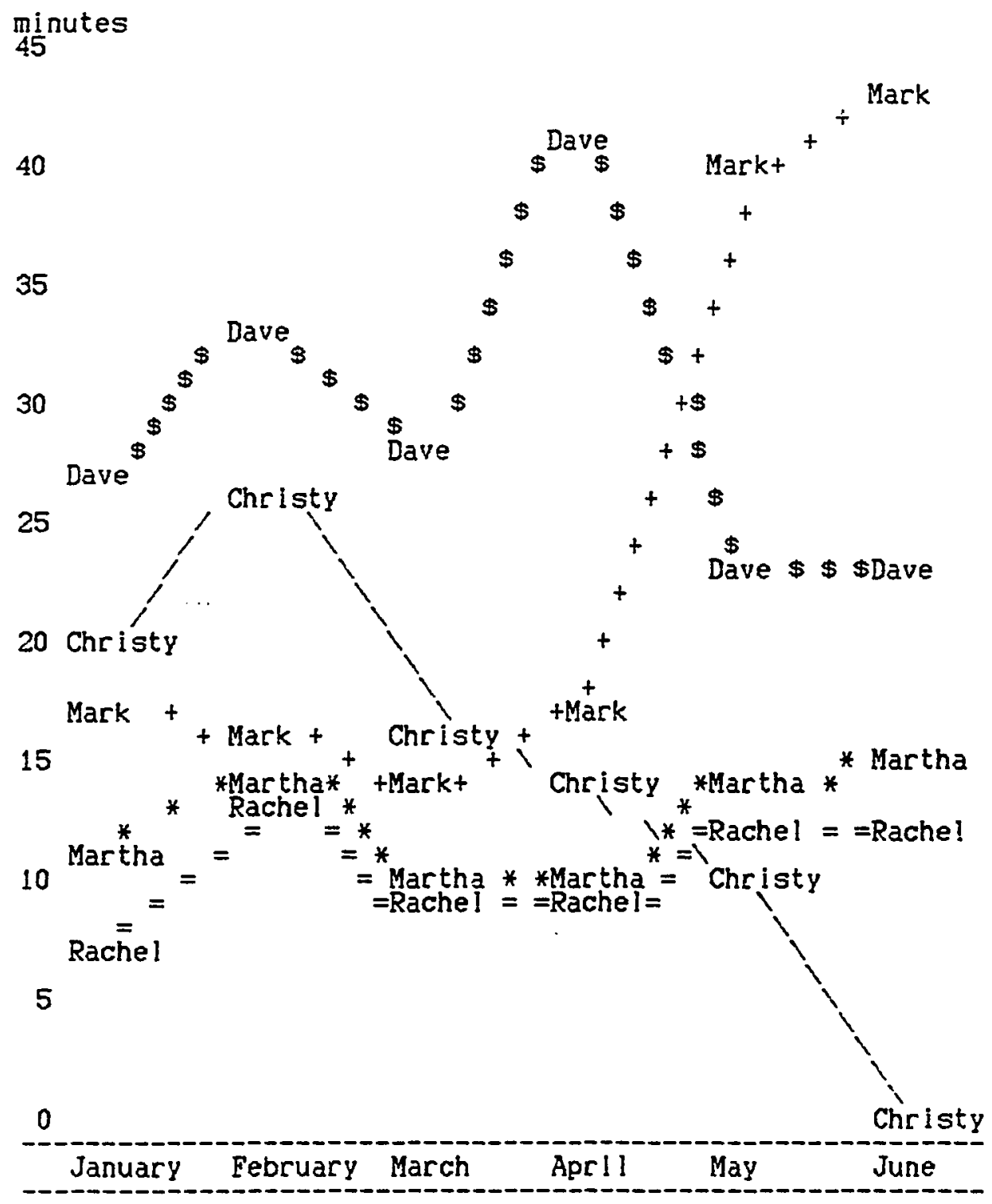

Floure 4.10 Graph of Subject's Average Monthly Time at Word processor recorded in minutes. (rounded of $f$ )

An analysis of Figure 4.10 indicates that Mark showed a slight decrease while the other four subjects increased their average per session time during the month of February. This was followed the next month with a decrease in their average per session time by all flve subjects. Thls inltial up and 
down movement depicted here may be an aspect of the subjects' excitment and their opportunity to explore written language and play with a new writing tool.

Through the second half of the data collection period, each subject, other than Martha and Rachel, displays a different time commitment pattern. Throughout the study Martha and Rachel were almost mirror images of one another as they increased their average time commitment per session. other than the subjects' general increase of committed time during February followed by decreases in March, and the mirror image of Martha and Rachel, other patterns displayed in Figure 4.10 are specific to individual subjects.

Following the general March decrease, two subjects decreased their time committments at one point or another during the last half of the data collection period. Even discounting Christy's non-participation during the one-word-processor-avallable-week in June, therefore no monthly average for June, her trend after February was downward. When analyzlng Table II and Tables IV and VI, it beomes apparent that as Christy's literacy became more sophisticated, she spent less time using a word processor. Table IV illustrates that Dave had a six minute session in May as well as three in the mid teens during his final print literacy episode. The effect of these short sessions was to decrease his average per session time durlng the months of May and June, as illustrated in Table IV. Except for Dave's 
May decrease, after the February peak, Christy is the only subject to exhibit a steady downward trend. Patterns and trends concerning time which are illustrated in Figure 4.10 and Tables II, IV, and V, are substantiated by data contained in Table VI. In addition to presenting monthly total amounts of time and averages, this data base also includes cumulative total and average times. Examining the numbers and patterns in Figure 4.10 and Table VI permits one to observe the increase or decrease in monthly amounts of time that subjects committed to using word processors. These numbers also allow comparison between subjects: those who spent a large number of minutes with word processors, like Dave, and those, like Rachel who spent less time. Copies of these data illustrating highs and lows of the various categories are included in Appendix E. 
TABLE VI

DATA BASE DEPICTING; MONTH OF STUDY, MONTLY TIME, CUMULATIVE TIME, MONTHLY AVERAGE TIME,

AND CUMULATIVE AVERAGE TIME OF

SUBJECT'S INVOLVEMENT WITH

WORD PROCESSORS

File: Time Analysis

Subject Month Total Time Cumulative Time Average Cumulative Average

\begin{tabular}{|c|c|c|c|c|c|}
\hline $\begin{array}{l}\text { Martha } \\
\text { Martha } \\
\text { Martha } \\
\text { Martha } \\
\text { Martha } \\
\text { Martha } \\
\text { Chr isty } \\
\text { Chr isty } \\
\text { Chr isty } \\
\text { Chr isty } \\
\text { Chr isty } \\
\text { Chr isty } \\
\text { Dave } \\
\text { Dave } \\
\text { Dave } \\
\text { Dave } \\
\text { Dave } \\
\text { Dave } \\
\text { Rachel } \\
\text { Rache } \\
\text { Rachel } \\
\text { Rache I } \\
\text { Rache } \\
\text { Rachel } \\
\text { Mark } \\
\text { Mark } \\
\text { Mark } \\
\text { Mark } \\
\text { Mark } \\
\text { Mark }\end{array}$ & $\begin{array}{l}1 \\
2 \\
3 \\
4 \\
5 \\
6 \\
1 \\
2 \\
3 \\
4 \\
5 \\
6 \\
1 \\
2 \\
3 \\
4 \\
5 \\
6 \\
1 \\
2 \\
3 \\
4 \\
5 \\
5 \\
1 \\
2 \\
3 \\
4\end{array}$ & $\begin{array}{r}53 \\
108 \\
62 \\
69 \\
86 \\
15 \\
98 \\
130 \\
98 \\
82 \\
30 \\
160 \\
131 \\
169 \\
203 \\
208 \\
68 \\
13 \\
80 \\
64 \\
49 \\
24 \\
12 \\
51 \\
80 \\
57 \\
85 \\
160 \\
171\end{array}$ & $\begin{array}{r}53 \\
161 \\
223 \\
292 \\
378 \\
393 \\
98 \\
228 \\
326 \\
408 \\
438 \\
43 \\
160 \\
291 \\
460 \\
663 \\
871 \\
939 \\
13 \\
93 \\
157 \\
206 \\
230 \\
242 \\
51 \\
131 \\
188 \\
273 \\
433\end{array}$ & $\begin{array}{l}10.6 \\
13.5 \\
10.3 \\
9.9 \\
14.3 \\
15.3 \\
19.6 \\
26.5 \\
16.3 \\
13.7 \\
10 \\
00 \\
26.7 \\
32.8 \\
28.2 \\
40.6 \\
23.1 \\
22.7 \\
6.5 \\
13.3 \\
9.1 \\
9.8 \\
12 \\
12 \\
17 \\
16 \\
14.3 \\
17.3 \\
40 \\
42.8\end{array}$ & $\begin{array}{r}10.5 \\
12.1 \\
11.5 \\
0.9 \\
11.7 \\
12.3 \\
19.6 \\
22.8 \\
20.6 \\
18.7 \\
17.1 \\
17.1 \\
26.7 \\
29.7 \\
29.2 \\
33.4 \\
30.3 \\
29.5 \\
6.5 \\
9.9 \\
9.7 \\
10.4 \\
10.2\end{array}$ \\
\hline
\end{tabular}

Analysis of data displayed in Tables IV through VI and Figure 4.10 reveal that there are no apparent relationships between individual subject eplsodes of print literacy evolution, illustrated in Table II, and the amount of time subjects spent in each of their episodes. Tables IV and V illustrate that even though subjects' average print literacy episode time may be similar, their total times are vastly different. Times for print literacy episode 2 , displayed in 
Table IV, illustrates that the three female subjects spent relatively the same amount of time per session, yet their total times were quite different. Also displayed within these figures and tables where total times are similar, per session times are often quite different. Table IV displays a one minute difference in total time spent for Dave's and Mark's print 11 teracy episode 4 , yet there is a vast difference between their individual per session time with a computer.

Examining Table II and Table VI reveals that there is no apparent relationship between the amount of time one uses a word processor for these subjects and their print literacy sophistication. Table II Illustrates that both Martha and Dave were writing stories by the end of their third month using a computer. Examination of Table VI reveals that by the end of the third month, Martha spent a total of 223 minutes with computers while Dave's time with a computer was 460 minutes. Although Dave spent twice as much time with word processors, both Martha and Dave began writing stories during the same week. These same figures and tables reveal that compared to Martha and Dave, Christy would not write stories for another six weeks, yet she spent 326 minutes with word processors by the end of the third month. Christy, not demonstrating the print literacy sophistication of Martha or Dave, spent 100 more minutes than Martha but 140 minutes less than Dave. Further examination of these figures lllustrates 
that per session time also supports the trend of no apparent relationship between time spent with a word processor and print literacy sophistication.

In summary, there are five apparent trends of interest represented in the time data. Except for Mark's slight decrease in February, one is the upward and then downward pattern exhibited by all subjects during the first three months of the data collection period. Secondly, there is Christy's continued downward trend after she peaked in February. Her written literacy continued to become more mature, as did that of the others, but her use of the word processor declined. Another interesting trend is the near mirror image of Martha and Rachel in their average time spent with a word processor illustrated in Figure 4.10. A fourth trend is no apparent relationship between individual subject episodes of print literacy evolution and the amount of time subjects spent in each of their episodes. Finally, there is no apparent relationship between the amount of time spent with a word processor and individual subject's print literacy sophistication. Other than these five, it appears that with regard to time commitments in using a word processor, there were no other signiflcant findings durling this investigation. 
Question - 2 .

How do the physical attributes of the computer

environment influence children's behavlor associated with word processing? For example: screen color or computer location.

Screen Choice. As data accumulated concerning choice of screen display, patterns and trends did not materialize. Figure 4.11 displays two data files which exhibit screen format preference data for two subjects. When analyzing this figure, it appears that neither of these two children possessed a preference for one screen display aver another. The closest that either of them came to demonstrating a preference was Mark's choice of screens with color displays during the month of February. 


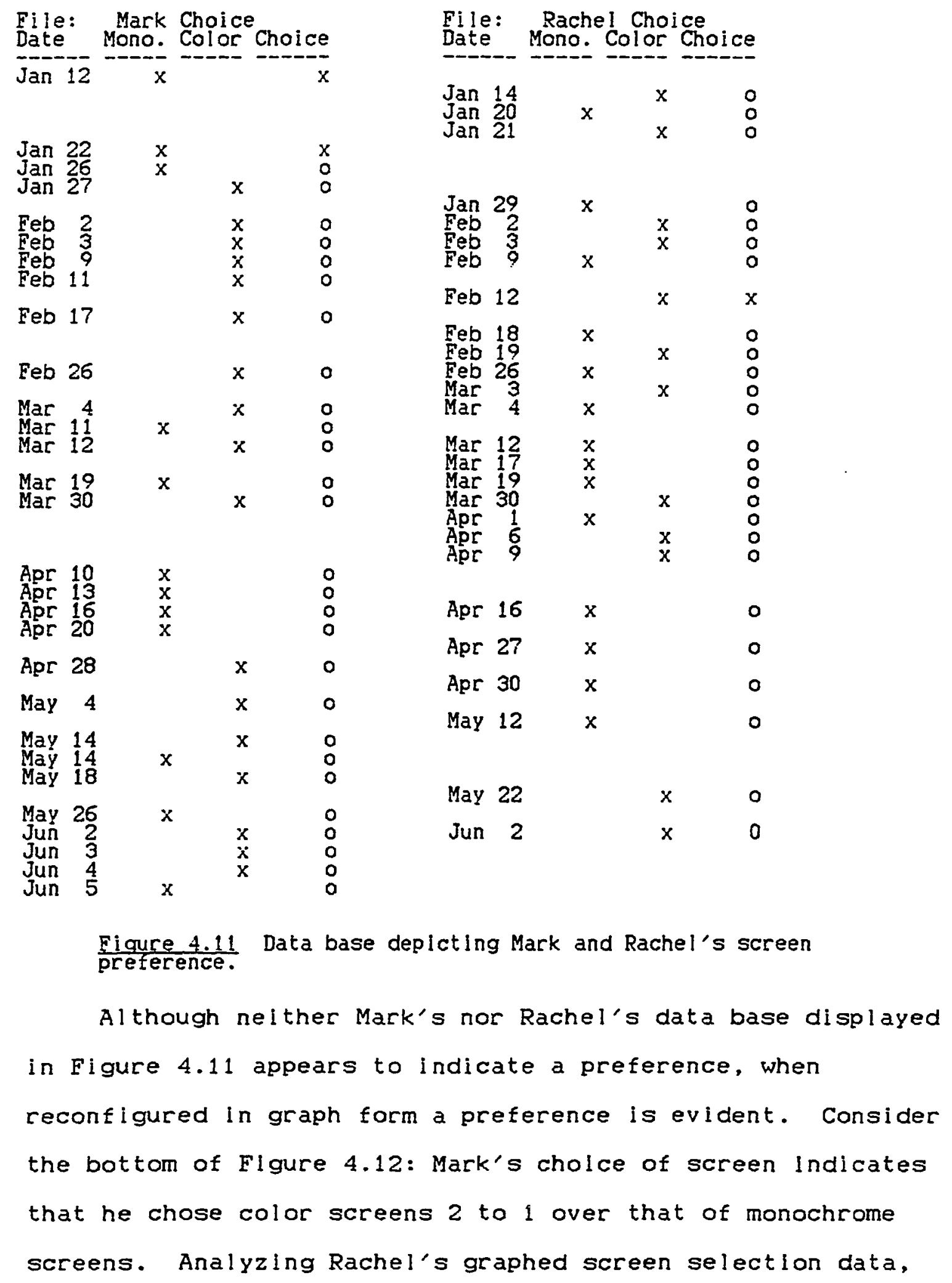


with close percentages of $44 \%$ and $56 \%$ respectively for color and monochrome, she does not appear to possess a preference, even though she chase monochrome screens more often than color.
Martha
$\mathrm{N}=34$

\begin{tabular}{|c|c|c|}
\hline \multirow{2}{*}{$\begin{array}{l}\text { Color } \\
\text { Mono. }\end{array}$} & \multicolumn{2}{|c|}{$\times \times \times \times \times \times \times \times \times \times \times \times \times \times \times \times \times \times \times \times \times \times \times \times 24-71 \%$} \\
\hline & $\times \times \times \times \times \times \times \times \times \times$ & $10-29 \%$ \\
\hline & Christy & $N=29$ \\
\hline Color & $\times \times \times \times \times \times \times \times \times \times \times \times \times$ & $13-45 \%$ \\
\hline Mono. & $x \times \times \times \times \times \times \times \times \times \times \times \times \times x \times$ & $16-55 \%$ \\
\hline & Dave & $\mathbf{N}=33$ \\
\hline Color & $\times \times \times \times \times \times \times \times \times \times \times \times \times \times \times \times \times \times \times$ & $19-58 \%$ \\
\hline Mono. & $\times \times \times \times \times \times \times \times \times \times \times \times \times \times$ & $14-$ \\
\hline & Rachel & $N=25$ \\
\hline Color & $\times \times \times \times \times \times \times \times \times \times \times$ & $11-4$ \\
\hline Mono. & $\times \times \times \times \times \times \times \times \times \times \times \times \times \times$ & $14-$ \\
\hline & Mark & $N=27$ \\
\hline Color & $\times \times \times \times \times \times \times \times \times \times \times \times \times \times \times \times \times \times$ & $18-$ \\
\hline Mono. & $\mathrm{x}$ & \\
\hline
\end{tabular}

Figure 4.12 Graph of subject's choice of color or monochrome screen. Nrefers to the number of opportunities children had to
chose screen color.

As one considers the graphed screen display preference data contalned in Figure 4.12 , it becomes obvious that there are two patterns of preference among the subjects. Martha's percentage preference for color screen displays is $71 \%$ to $29 \%$. Considering just percentages, Mark's preferences are similar to Martha's. Nelther Chrlsty, Dave, nor Rachel 
appear to favor a specific screen display. Of the flve study subjects, two appear to indicate preference for color screen displays while three possess no apparent preference.

Computer Choice. Figure 4.13 illustrates hardware computera and printers) positions in the word processor center. Within this center, two printers are color coded and networked to the word processors. Each printer supports three word processors. Monitor screens are positioned in such a manner that when sitting at one, a child is looking toward the middle of the learning center. If a child were to sit at computer "Green 3," s/he would face toward the west wall while most of the room would be to his/her back. Further examination Indicates that a child sitting at computer "Blue $2^{13}$ would face toward the middle of the room with windows to hls/her back. While there was little foot traffic along the windows (south) and wall (west) sides of this learning center, children sitting at the green computers often had others walking behind and next to them. 


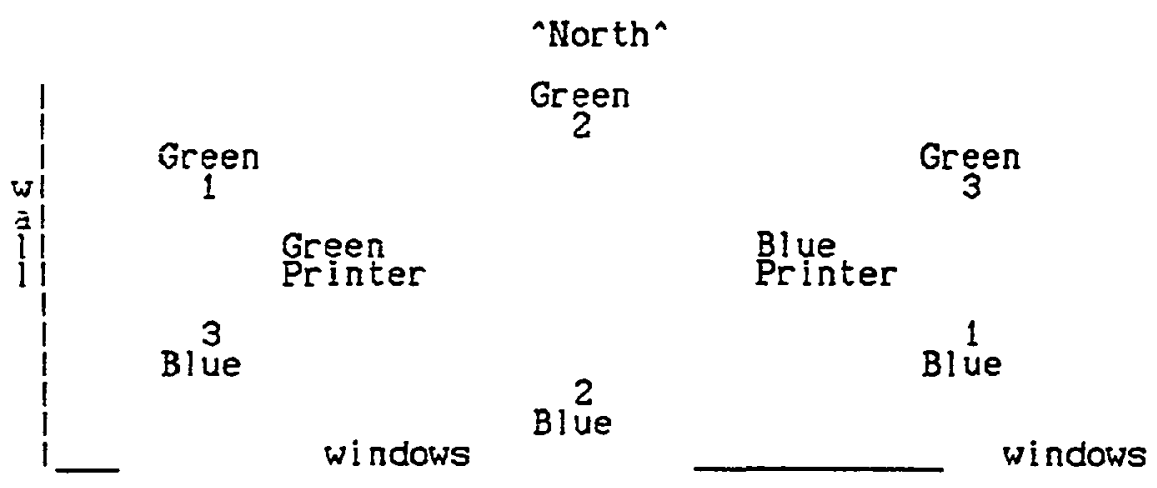

Fiqure 4.13 Diagram of word processor center.

Children were observed to cruise the word processor center, walking around the center looking at monitor screens and students writing. As subjects cruised the word processor center looking for a word processor, they were often limited to their choice of computer. Commonly, other students were already using them to write. Even though this was generally the case, certain trends and patterns of use emerged. While certain subjects appeared to possess a preference for specific computers, other subjects appeared to avoid certain computers or locations within the center. Figure 4.14, a display of Dave's computer choice data base, reveals his initial preference for computer "Blue 1." As indicated in Eigure 4.14, Dave's preference extended through the initial three months of his access to the writing lab and word processor center. 


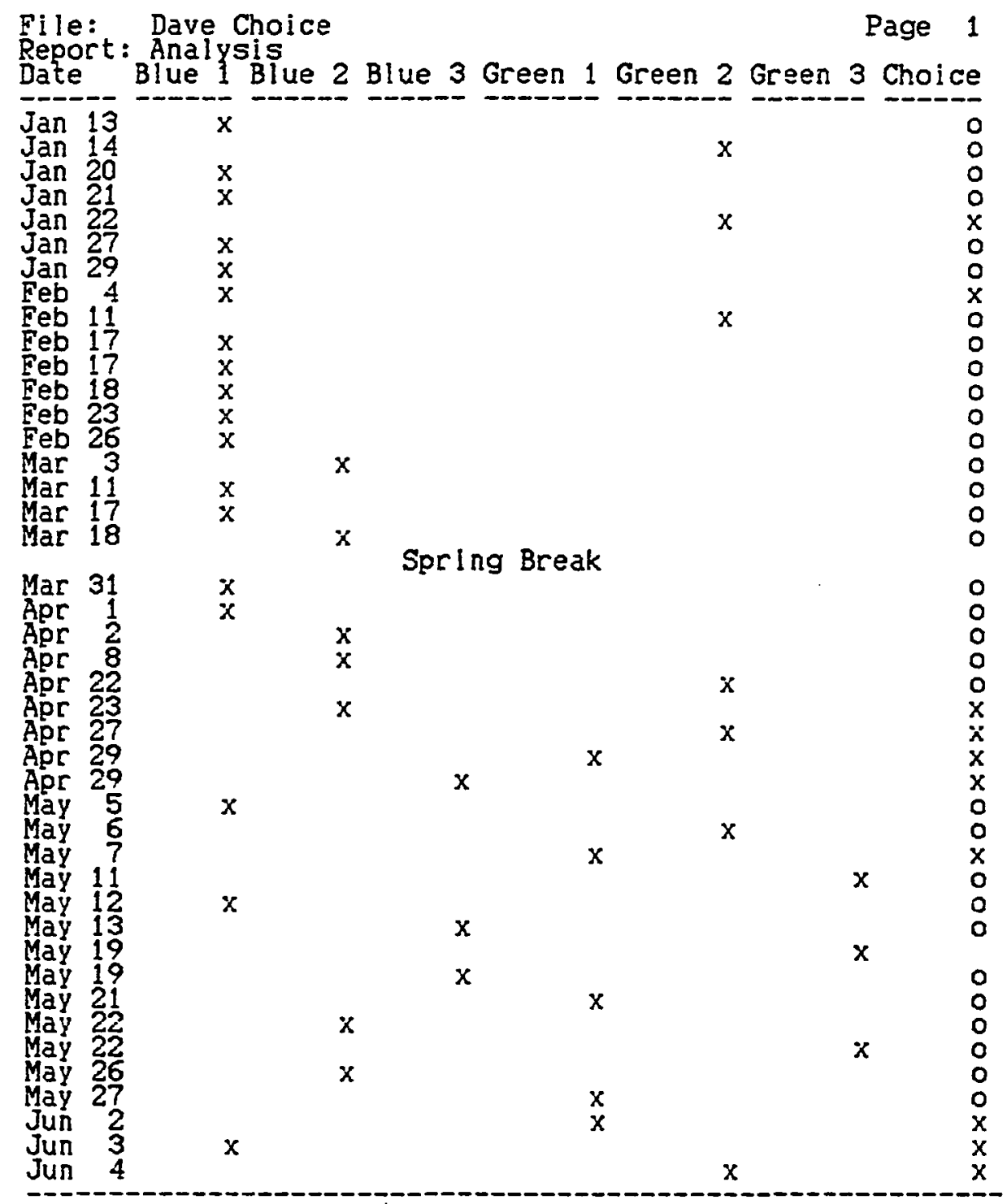

Fiqure 4.14 Display of Dave's computer choice data base.

Twice during the first three months I recorded Dave's initial commitment and preference for computer "Blue 1 " in my "Dave Journal." His actions and behaviors indicate his intent at wanting to use this particular computer. 
$1 / 29 / 87$ Thursday

There were four computers available today when Dave arrived at the WP center. He waited until Ryan completed her work at the one ["Blue 1"] she was at, [Dave] cleared the screen with confirmation directions from me, and then sat down and began to work.

$2 / 26 / 87$ Thursday

What I thought was interesting this morning is that on the way to the writing table [from the CAI computers], Dave diverted his path to the WP center. There he coerced Matthew away from the B1 [B!ue 1] WP [word processor] and began to use it himself. Matthew was almost $f$ inished with his work anyway, but by the time Dave told him he was wrong and off task and told him to clearl,] which is what Matthew was going to do anyway, Matthew left and the BI WP was open to Dave to use, which he did.

Following Spring Break, as Indicated in Figure 4.14, Dave began to diversify his word processor selection. During the last two months of the data collection period, Dave no longer indicated a preference for a specific computer.

While Dave indicated a preference for a particular computer, another choice pattern to emerge was that of the apparent avoidance of computers located in certain sections of the word processor center. Examination of Table VII illustrates that both Christy and Mark appeared not so much to prefer certain word processors, but to avoid specific areas of the center. Christy displays a tendency to avoid using word processors "Blue 1" and "Blue 2" while Mark appears to avoid using "Blue 1" and "Green 3". The two computers which Christy declines to use have the most amount of natural light hitting their monitor screens. Her avoidance may be a preference to use computers with lighting sources from above rather than behind. Christy is physically 
very small, much smaller than the other subjects. Her size, in relation to those two particular computers and the ir lighting may be an aspect to her avoidance. Mark's avoidance of "Blue 1" and "Green 3" allowed him to sit at word processors where he could look around and standing up look over monitors to see what was occurring in other parts of the room. Mark was commonly involved with others, socializing, when working at the word processor center as the following entries in my "Mark journal" Indicate. Mark's social involvement with others extended beyond the word processor center.

$3 / 4 / 87$ Wednesday

He was out of $h$ is seat quite often talking with other kids or looking at what they were doing at their WP. At $t$ imes he also seemed much louder than at other times. Al though he wrote more today than any other time I've observed him, he also wasn't as focused, out of his seat, talking to others, and movement about the WP center.

\section{$6 / 3 / 87$ Wednesday}

Mark was up and out of $h$ is seat a great deal today, almost every little thing set him in motion away from the activity of being focused on his WP work. At times he was off looking at other people's screens whlch included comments at times on what he saw. Other trips out of his seat included chats with others about what they were writing, wanting to help others, how to write a certain punctuation mark or discussion about the content of what was being written. 
TABLE VII

COMPOSITE OF SUBJECT'S WORD PROCESSOR CHOICE*

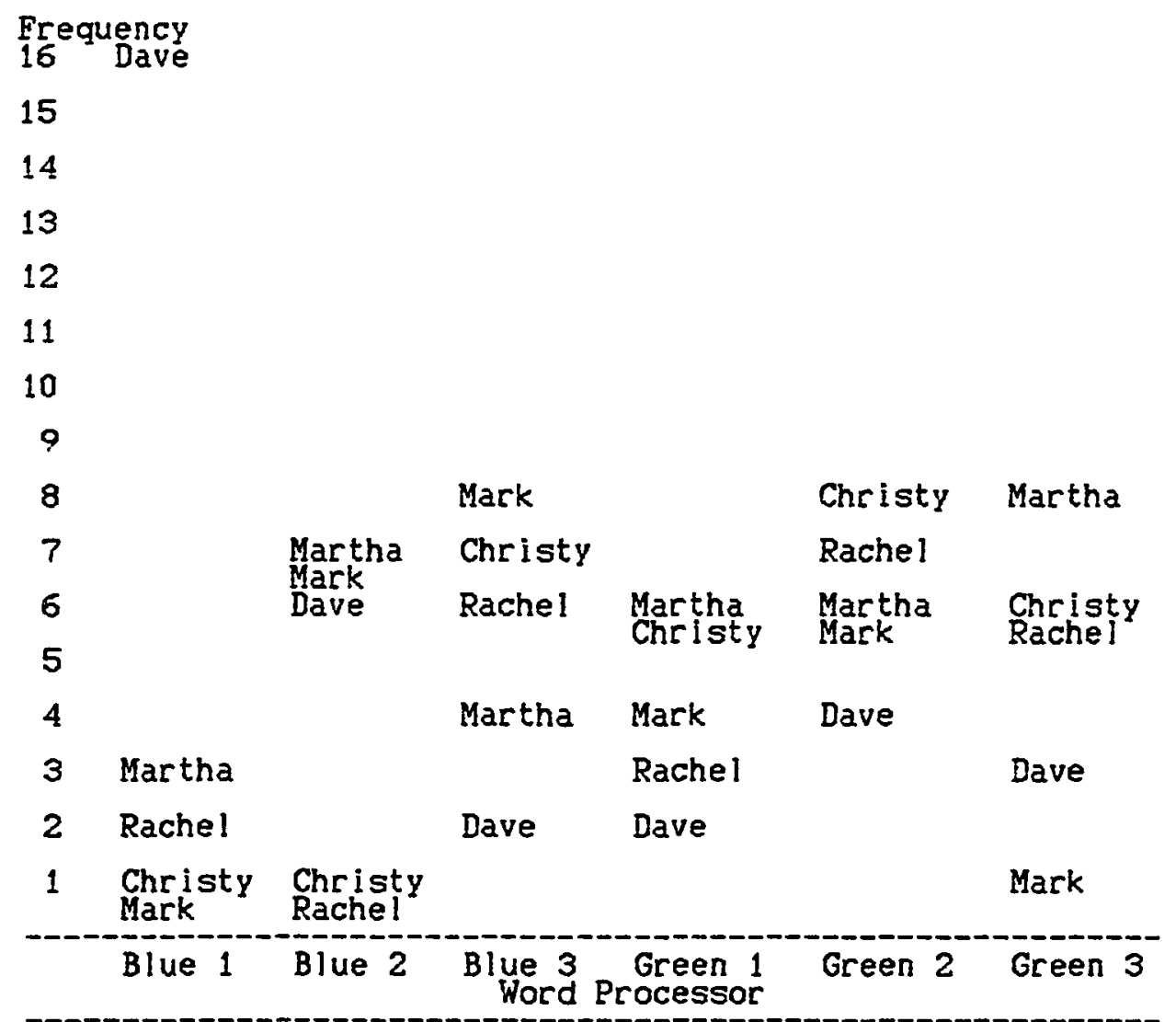

* Martha $\mathrm{N}=34$, Christy $\mathrm{N}=29$, Dave $\mathrm{N}=33$, Rachel $\mathrm{N}=25$, Mark $\mathrm{N}=27$.

Rachel displayed a slmilar pattern to that of Christy's. She appeared to avoid using "Blue 1 " and "Blue 2." However, since Rachel's data does not indicate as many word processor center contacts, her trend does not seem as pronounced as Christy's. Rachel appears more diversified, but not to the extent of Martha. Martha's contacts were spread throughout the word processor center. Indlvidual print outs of each 
subject's computer choice data base displaying computer and screen choices is contained in Appendix G.

Percentage data displayed in Table VIII collaborates these findings. Table VIII displays percentages of the subject's word processor choices. Dave's preference was for word processor "Blue 1 " and he chose that computer $48 \%$ of the time. Christy used "Blue 1" and "Blue 2" each $3 \%$ for a total avoidance of that area of the word processor center of $94 \%$. Mark used "Blue 1 " and "Green 3 " each $4 \%$ for a total avoidance time of that area of the word processor center of 92\%. When examining Tables VII and VIII it becomes apparent that certain trends towards the use or avoidance of particular computers existed, but these data do not explain why. 
TABLE VIII

PERCENTAGE OF SUBJECT'S HORD PROCESSOR CHOICES

$100 \%$

48 Dave

45

40

35

30

25

20

15 Martha Rachel

5

Mark

Christy Christy
Mark

Christy

Mark

Christy

Martha

Dave

Christy

Martha

Mark

Martha Rachel Dave

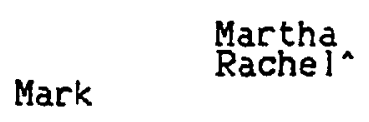

Martha Christye 
in Figure 4.10 and Table VI, Dave usually occupled a computer for approximately one half hour. His behaviors were such that his peers probably became aware of his preference for "Blue 1". From his initial word processor access in January until April 1, Dave was at the word processor center 20 times, 18 of which he had a choice of which computer to use. During this time period, the subject's class visited the writing lab 50 days. Over $60 \%$ of the days, Dave did not participate in the word processor center. As previously expressed in my journal entries, other non-subject students, Ryan and Matthew, in addition to study subjects were using this particular computer. Although Dave utilized "Blue 1" often, this computer was an available option to other students.

Use of Printer. From the beginning of their access to the writing lab, students used printers networked to the word processors. Initially adults printed for students, but as adults demonstrated and explained the printing process, students began to learn about computer systems. Wlthin a few days, students were manipulating keys and switch box dials as adults led and talked them through the printing process. As indicated in Figure 4.15, within a month, two subjects were able to manipulate the computer system in order to print a hard copy of their own document. However, there were those who had difficulty managing the printing procedure and one who never printed her own documents. 


\begin{tabular}{|c|c|c|c|c|c|c|}
\hline$\frac{\text { Behavior }}{\text { by acuit }}$ & $\begin{array}{l}\text { Martha } \\
\text { Christy } \\
\text { Dave } \\
\text { Mark }\end{array}$ & Martha & & & & \\
\hline by peer & & $\begin{array}{l}\text { Martha } \\
\text { Rachel }\end{array}$ & & Martha & Mark & \\
\hline with peer & $\begin{array}{l}\text { Martha } \\
\text { Christy } \\
\text { Dave } \\
\text { Rachel }\end{array}$ & $\begin{array}{l}\text { Mar tha } \\
\text { Christy } \\
\text { Dave } \\
\text { Rachel } \\
\text { Mark } \\
\text { Martha } \\
\text { Chr lsty } \\
\text { Mark }\end{array}$ & $\begin{array}{l}\text { Martha } \\
\text { Christy } \\
\text { Dave } \\
\text { Rachel } \\
\text { Mark } \\
\text { Christy } \\
\text { Rachel }\end{array}$ & $\begin{array}{l}\text { Martha } \\
\text { Christy } \\
\text { Dave } \\
\text { Rachel } \\
\text { Mark } \\
\text { Christy } \\
\text { Rachel } \\
\text { Mark }\end{array}$ & $\begin{array}{l}\text { Martha } \\
\text { Christy } \\
\text { Dave } \\
\text { Mark } \\
\text { Martha } \\
\text { Christy }\end{array}$ & Rachel \\
\hline by self & Dave & $\begin{array}{l}\text { Martha } \\
\text { Dave }\end{array}$ & $\begin{array}{l}\text { Martha } \\
\text { Dave }\end{array}$ & $\begin{array}{l}\text { Martha } \\
\text { Dave } \\
\text { Rachel } \\
\text { Mark }\end{array}$ & $\begin{array}{l}\text { Martha } \\
\text { Dave } \\
\text { Rachel } \\
\text { Mark }\end{array}$ & $\begin{array}{l}\text { Martha } \\
\text { Mark }\end{array}$ \\
\hline & January & February & March & April & May & June \\
\hline
\end{tabular}

Fiqure 4.15. Composite of subject's involvement in the printing process during the study.

Growth in Flgure 4.15 is represented by movement from the upper left corner down towards the bottom right corner. Since two subjects did not have the opportunity to print during June, there are only three names in the column for that month. This figure indiates that by the fourth month of their involvement with a computer system all subjects, except for one, were able to manipulate the technology in order to print for themselves. After the first four to six weeks, generally, adult assistance was only necessary if there were printer or software problems, or simply for confirmation about the process. Once chlldren understood the printing procedure, peer assistance became common and was observed usually to be on the basis of sharling and wanting to be 
helpful as opposed to having to help someone because they were unable to print on their own. At times some of this assistance was unsollcited as 11 lustrated in the following entry from my "Martha Journal."

$2 / 18 / 87$ Wednesday

Martha came back for a second time today. She initially began the day at the WP's and then finished the day there also. It's interesting to note that when she was there, both times, she did a lot of helping or wanting to help kids print. She did this even when kids didn't want her help. Rachel told her that she didn't need any help from her, but Martha kept right on interacting with her, telling her what to push and pushing some keys herself.

Illustrated in Figure 4.15, and substantiated by the data base information displayed in Figure 4.16, Christy never completed the printing process on her own. She followed adults and peers through the printing process and attempted it herself many times. The following entry, taken from my "Christy Journal," explains the technlque adults used with Christy and other students to teach the printing process. This entry also lllustrates one of Christy's attempts to print on her own.

\section{$3 / 10 / 87$ Tuesday}

She then got into printing and clearing. This took the majority of her time at the WP. At first she told Brenda she wanted to print. Brenda asked if she knew how and she confirmed that she did. Next she went back to the WP and tried for the longest time to print. She didn't have much success with it [printing process]. She tried a number of times, but often missed the print selection on the edit screen. She finally went to Brenda and requested some asslstance. Brenda then verbally took her through the printing process telling her what to do each step of the way and allowing Christy the opportunity to do it [manipulate the technology]. 


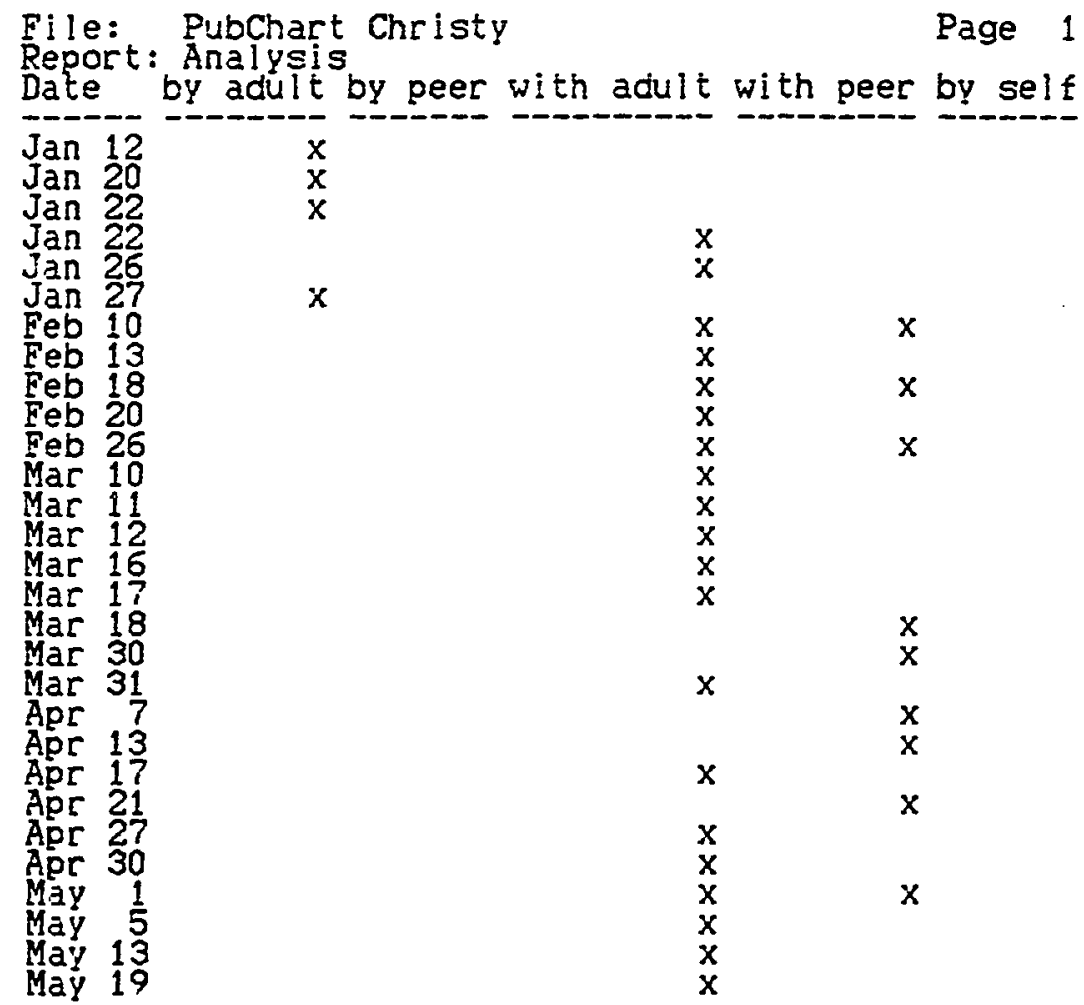

Ficure 4.16 Display of Christy's printing behaviors data base.

The growth pattern displayed in Figure 4.16 moves from the upper left to the lower right corner. Upon examination, one observes that Christy moved towards self-sufficiency but always had to rely on another's assistance. Data bases contained in Appendix $H$ indicate that there was a wide variety in how quickly subjects gained skills in manipulating the printing process. Dave and Martha were the first subjects to successfully print their own documents. Figure 4.15 illustrates the three month spread between the first subject, Dave, and the last subjects, Rachel and Mark, to demonstrate self-sufficiency in printing. 
In reference to Chapter II and the section on cognition, young children find it difficult to mentally visualize the whole of something and its parts simultaneously. When printing at one of Sabin's PCJr. computers, not only must an operator manipulate the software, but they must also turn the network box switch to the number of the computer they are controling. In order to turn the swltch it is necessary for the writer to physically move from his/her computer to the printer switch box located next to the printer, turn the switch, return to his/her word processor and follow the software printing commands. This procedure appeared confusing to some children. The following entry is taken from my "General Journal."

\section{$3 / 12 / 87$ Thursday}

There appears to be a hang up for some $k i d s$ when it comes to printing. The procedure is fairly straight forward, but suddenly there are problems when they get to the point of the switch box. They can print or at least follow the procedure to print, but when it comes to going through the print procedure and then going over to the switch box to turn to the correct number of [the] WP, they lose where they are. They are trying, but the ambiguity of the setting may give them problems. The switch box is not on the procedure card. Maybe If that was Included more kids would go ahead and print? Yet, it's not the most clever kids or anything like that who can print or can't, it's a number of children. I wonder what the variables are which are working here?

This entry was written in mid March. By the first week in June, almost every member of the class was able to complete the printing procedure on his/her own. Of the research subjects, Christy was second youngest and still not a self-sufficlent printer. In contrast, as Figure 4.17 
illustrates, once Mark, second oldest, demonstrated that he could print on his own, often required peer and adult assistince. In reference to Table II, Christy and Mark appear to be the least sophisticated in print literacy. According to data contained in Figure 4.15, they are also the least sophisticated in printing their own documents.

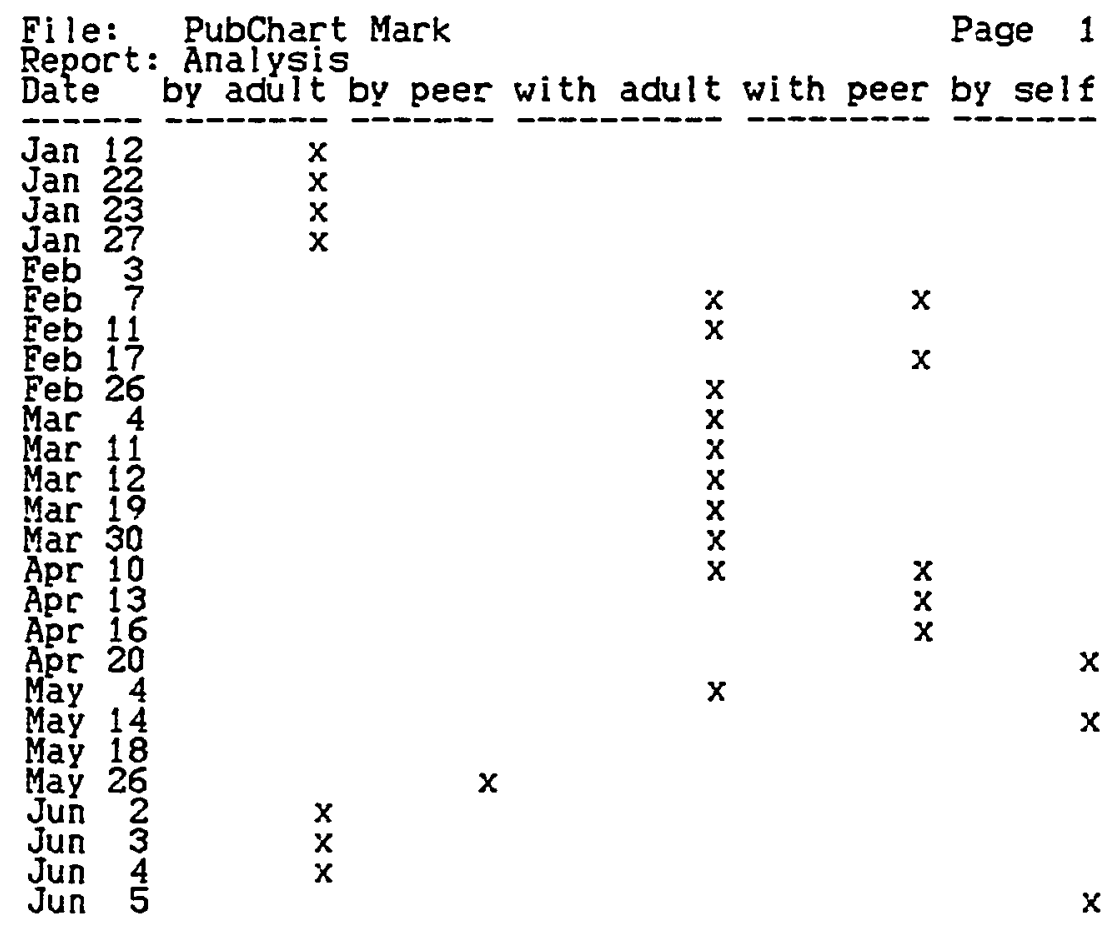

Floure 4.17 Display of Mark's printing behaviors data base.

Regarding Figure 4.17, the three June entries in the column "by adult" refer to my saving Mark's document on a file disk since Mark was copying from a book and asked to have his text saved each day for retrieval the following day. On Friday June 5, Mark printed multiple copies of his 
document using both the software printer controlled functions and the hardware controlled print screen function.

Dally publishing of one's document was a common activity in the word processor center. Figure 4.18, a display of relevant data from Dave's "PubChart" data base, indicates the popularity of printing during each word processor contact session. It is apparent from this figure and data bases contained in Appendix $H$ that subjects desired a copy of their document. Initially, subjects printed copies for themselves, but in time began to share their document with others. As illustrated in Figure 4.18, Dave shared print outs of his document as well as received documents from peers. During the last few days in June, Dave had his document saved since he was copying from a book and intended to print his entire document when finished. School closed for summer break before he had an opportunity to publish. 
File: PubChart Dave Report: Print Analysis

Page 1 Date by adult with adult by self

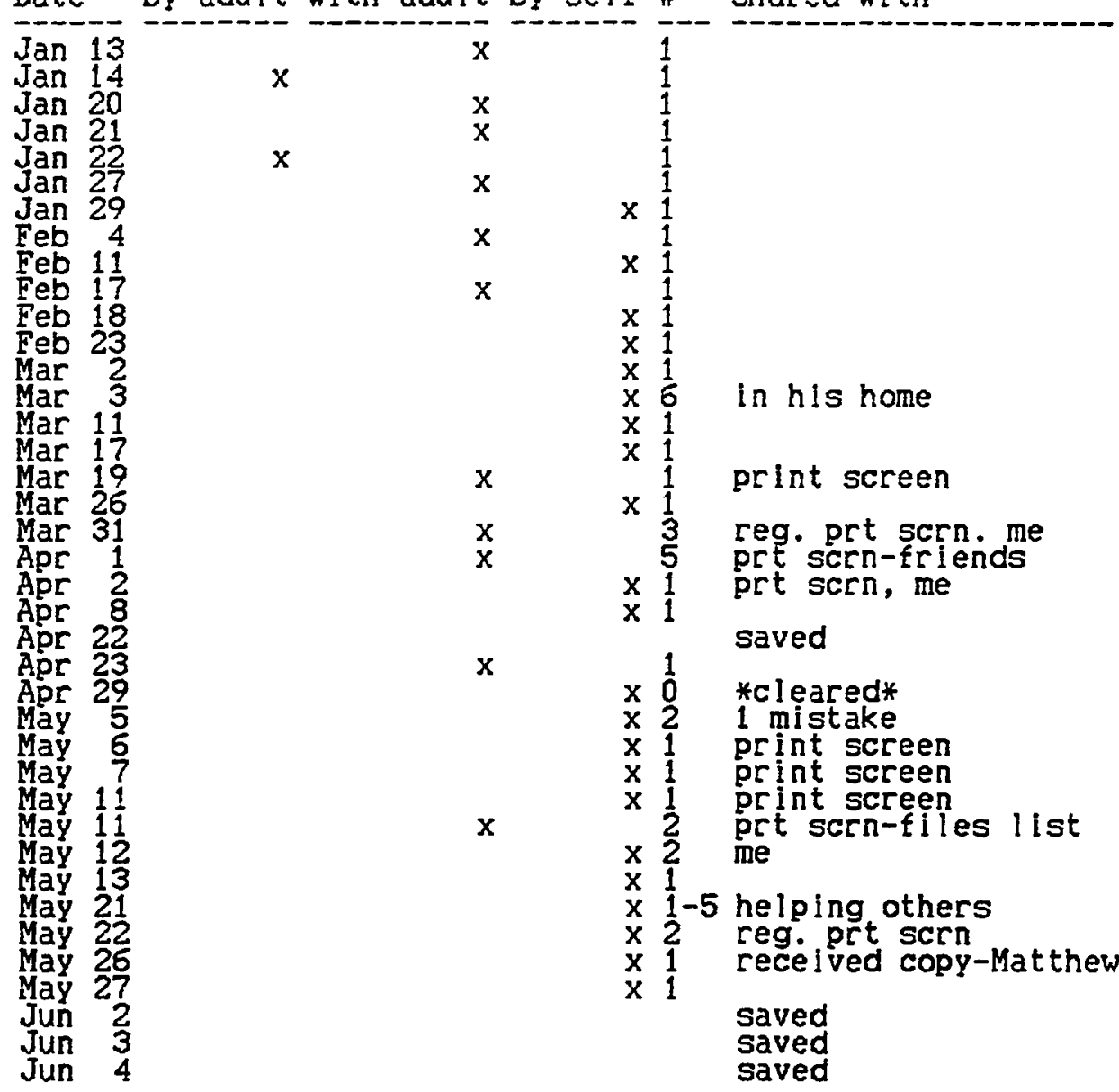

Fiqure 4.18 Display of relevant data from Dave's data base.

The following entry from my "Dave Journal" indicates the sharing of personally printed documents. It also offers examples of meta-lingulstics practiced among peers, assisting peers in printing, and colleagial sharing and writing. $5 / 26 / 87$ Tuesday Dave and Matthew worked together for 55 minutes today. Initially they were into exploring and dolng the old print screen stuff. This also included helping other $k i d s$ work out the printing. After about 10 or $15 \mathrm{minutes}$ they got into writing words and short phrases. Some of the kind of stuff that Dave used to do before he began to write stories. The 
two of them did a lot of talking back and forth about their work and their writing. They were sharing ideas. This didn't get into sharing the spelling or sounding out as long as I was observing their interactions. But they did a lot of sharing about the topics and words they wanted to write. At one point the sub [substitute teacher] came over and told the two to stop the playing and get on with their work. They explained what they were doing and then continued on with their writing. When it was time to print, they both shared copies of their own work with one another.

Letter Preference. Associated with publishing one's written documents is the use of letter form, ie. upper, lower, conventional, or mixed case format. In this study, subjects displayed a varlety in their use of letter formats. An analysis of Figure 4.19, individual subject data bases contained in Appendix I, and Tables IX - XI, Indicates that some subjects held certain preferences while others appear to hold none. Further analysis of Figure 4.19 indicates no apparent trends within the group of subjects, the data illustrates Individual preferences. 


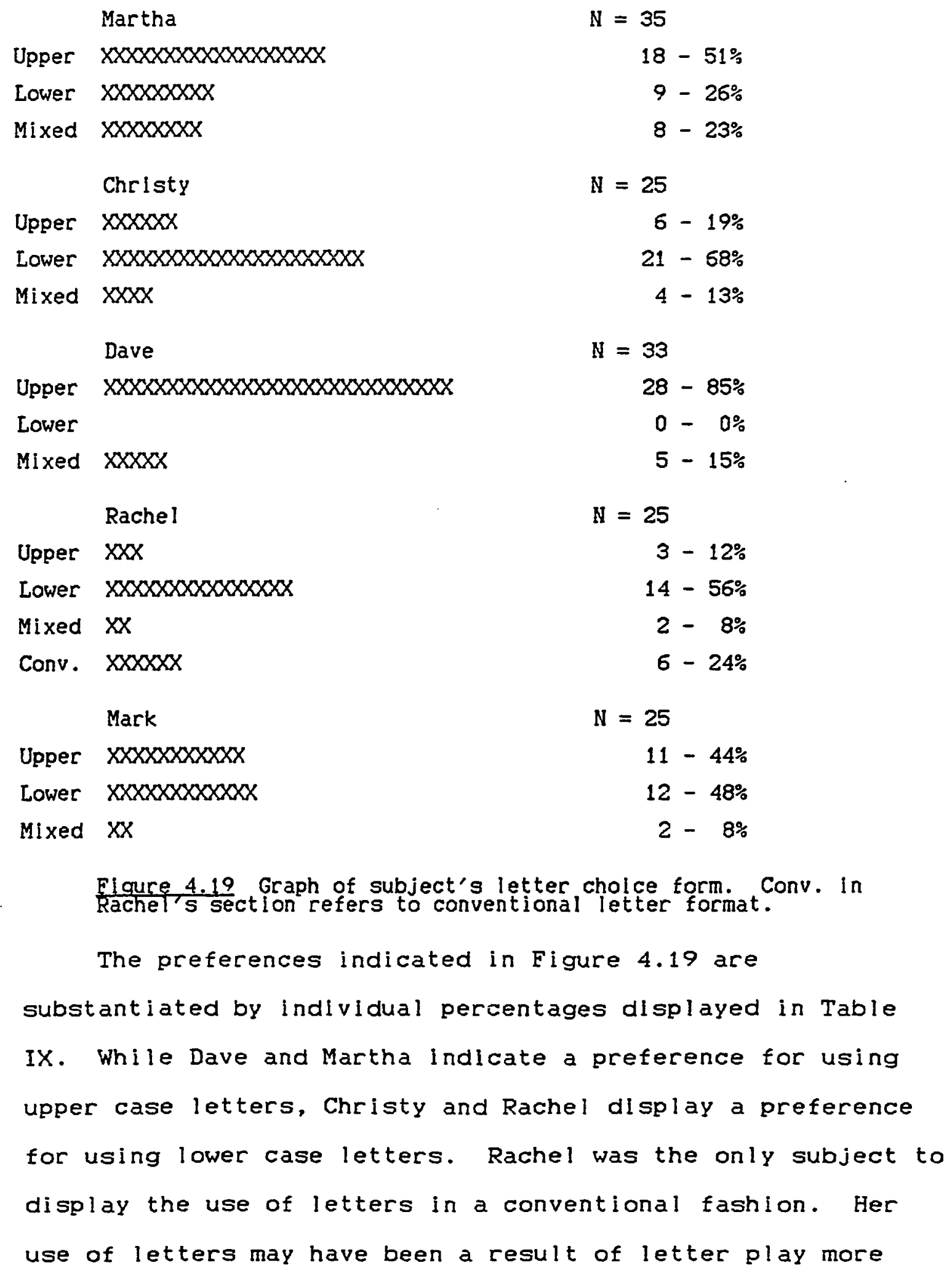


than knowledge of English language conventions since she did not capitalize nouns with any consistency but would often capitalize word strings. Regarding data contained in Figure 4.19, Table IX, and Appendix H, children displayed little mixing of letter cases.

TABLE IX

COMPOSITE OF SUBJECT'S LETTER FORM CHOICE PERCENTAGE

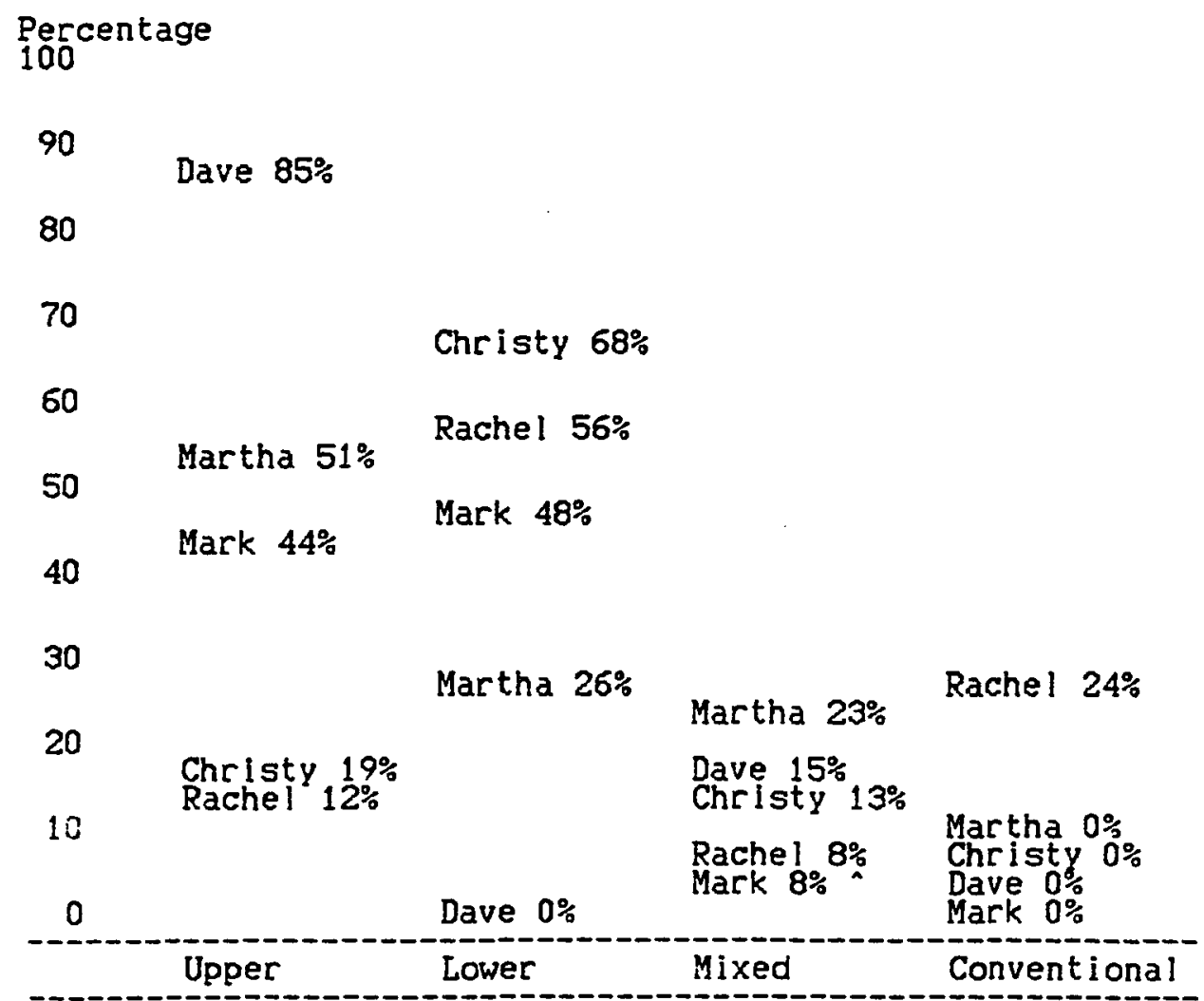

Tables $X$ and XI dlsplay two subject's "Letters" data bases, one indicating an apparent letter format preference, the other no preference. As lllustrated in Table X, Dave's 
use of upper case letters $85 \%$ of the time indicates that he prefers the use of upper case letters. Analysis of the comments column indicates that four out of the five times Dave mixes upper and lower case letters, the vast majority of letters in his document are upper case. In contrast, data displayed in Figure 4.19 and Tables $I X$ and XI indicate that Mark, with selection percentages near $50 \%$, appears not to possess a letter format preference. 
TABLE $X$

DATA BASE DISPLAY INDICATING Dave'S LETTER FORM CHOICE

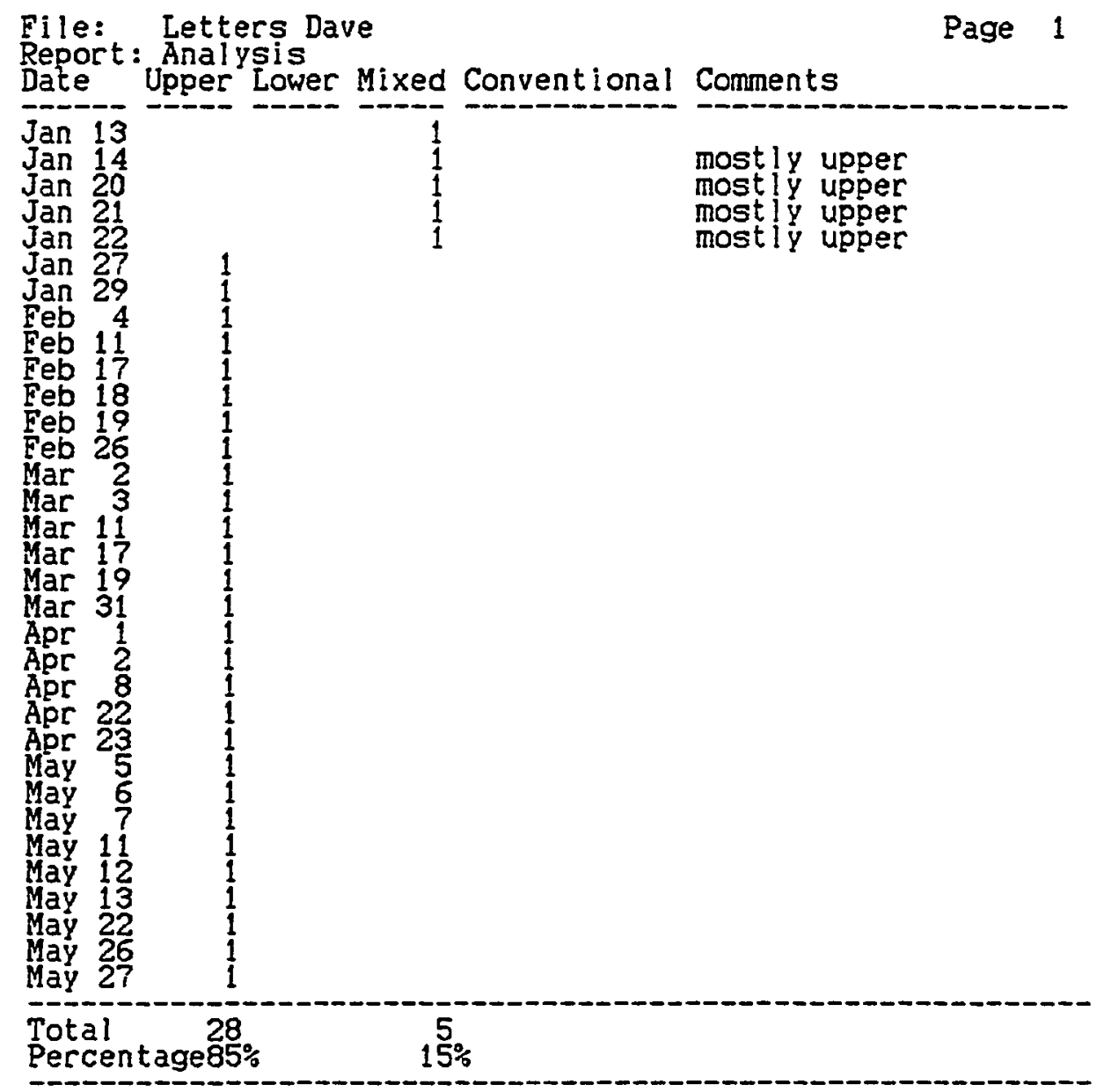


TABLE XI

DATA BASE DISPLAY INDICATING Mark'S

LETTER FORM CHOICE

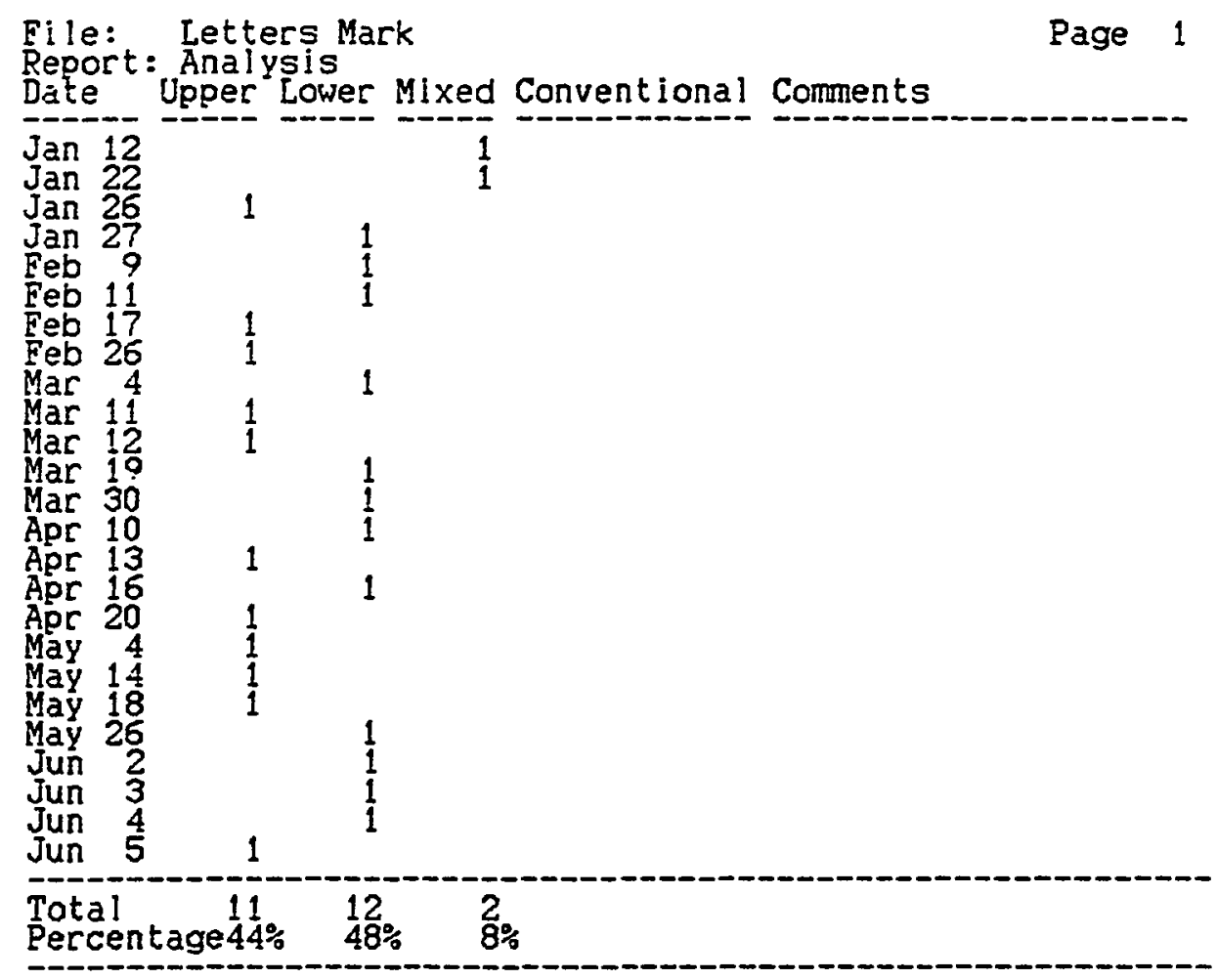

\section{ADDITIONAL EINDINGS}

The following two incidents occurred during preliminary research conducted in 1986. The first incident occurred during the spring. At that time, preliminary research was being conducted in two of five kindergarten classes scheduled for an hour each day in the writing lab. No one associated with these two classes realized what had evolved until April, during the kindergarten students' fourth month of access to word processors and the writing lab. At that time it was discovered that in both classes, with the exception of one 
girl, all students who took control of the computer system and exhlbited publlshing self-sufficiency were boys. When finished writing, girls would continue to sit quietly, raise a hand and wait until an adult, who noticed their signal, came and printed their document for them. Meanwhile, many of the boys had learned early on, as Dave did, how to control the computer system and publish their own documents.

Not an expected development, this gender phenomenon simply evolved. The only exceptions to this tendency were boys who generally did not appear as intellectually and socially mature as their classmates. It appeared that these boys were often viewed as not "being able" and needing help. As indicated by data presented earlier, Figures 4.15 to 4.18 and other related figures in Appendix H, a discrepancy of this magnitude did not materiallze this year.

The second Incident occurred in late September 1986. I was using overhead transparencies in a workshop on the use of word processors with young children. The transparencies were samples of students' work without names, similar to Figure 4.2, representing evolutionary literacy growth of kindergarten students. Attendling this workshop was a teacher new to our bullding. Two subjects from the preliminary study were in her classroom. While I was displaying Nadir's literacy growth transparencies, the teacher spoke up and asked if it was Nadir's work. This incident is significant in 1 ight of Brisk's (1985) research reported in chapter 2: 
"Neither the word processor nor the printer revealed the identity of the "real' author" (p. 28). Though personal handwriting style can not be utilized for identifying authors who use a word processor, it is apparent that there can be other characteristics of written language to assist in identifying authors. 
CHAPTER V

SUMMARY, FINDINGS, AND CONCLUSIONS

SUMMARY

Restatement of The Problem

During this decade of the 1980 s, many young children are experiencing the opportunity to use microcomputers. It is not uncommon for kindergarten students to use microcomputers as word processors. Computers are literacy tools new for school curricula, educational leaders, and young children. Various scholars have proposed questions related to young children using these machines in their print literacy development. Newman (1984B) shares these questions concerning

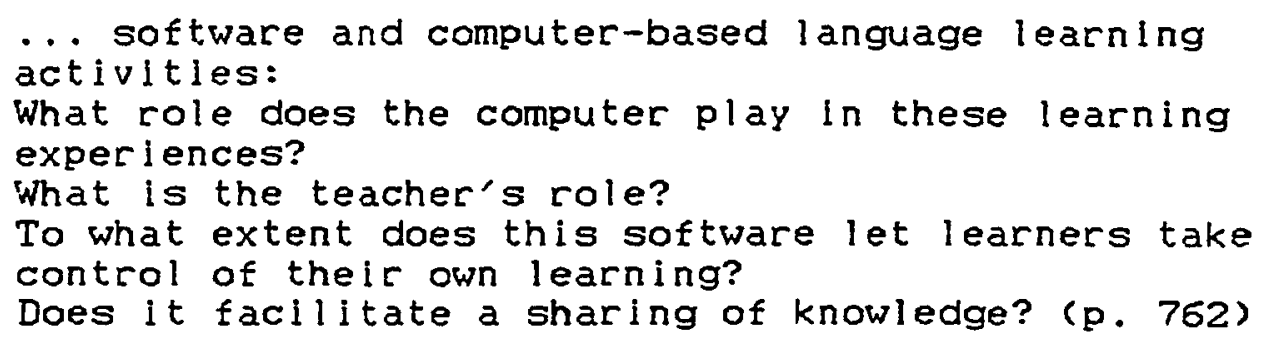

Spencer and Baskin (1983) pose questions directly related to word processing and early childhood education.

When is a child old enough to effectively use a word processing program to type letters of the alphabet, numbers, and other symbols? 
At what point can a word processor ald a child in beginning to write simple sentences, paragraphs, staries, or poems? (p. 21)

These questions and others found during a survey of related literature led to the formulation of a study statement and questions which became the focus of this investigation.

\section{Study Statement}

-

If given the opportunity, how will children use word processing in their print literacy development during their Kindergarten experience?

Pracedure. Since the opportunity for children to use computers is a recent phenomenon in early childhood education, it was felt that a research design utilizing certain ethnographic techniques provided the most promising and valuable approach. Study questions were developed and refined. Following more than a year of preliminary research, review of relevant 1 iterature, discussions with professionals in related fields, and development of a naturalistic research design, the formal data collection period of this investigation began in January 1987.

Study Quest lans.

1. What developmental sequences related to print literacy reveal themselves as kindergarten chlldren use a word processor? 
1a. In what ways are these sequences the same as or different from those identified by researchers studying young children's use of pencil and paper?

1b. What type of time commitments do children make at each stage of these developmental sequences?

2. How do the physical attributes of the computer environment influence children's behavior associated with word processing? For example: screen color or conputer location?

Subjects. Originally, six children representing a variety of intellectual, raclal, and econcmic backgrounds were selected as subjects. WithIn six weeks, one of the subjects moved to a new school and was lost to the study.

Data Collection. The formal investigative-observatlonal data collection period of this study continued for approximately 5 months. Observations were conducted and recorded dally with follow up journal entries. Subjects' literary products were saved and collected daily. Also, portions of the recorded data were transferred to refining instruments both daily and weekly.

Data Collection Instruments. Once the study questions were finalized, various data collectlon and analyzing instruments were created. These instruments were created in paper and Ink as well as electronic form. In addltion, it was decided to keep seven journals, one for each of the subjects plus a general journal for recording group and 
classroom word processor, print, and technolagy related behaviors. Except for the journals, which consist of typical log type entries, examples of these recording and refining instruments are contalned in the Appendices.

Data Analysis. As the recorded data began to accumulate, certain patterns, trends, and themes became apparent among the subjects. These patterns, trends, and themes generally became clearer once the data collection period was completed and analysis begun. Analysis of the collected data leads to the following three sections:. findings, conclusions, and recommendations.

\section{FINDINGS}

\section{Subjects' Print And Technological Sequences}

Print Literacy. Subjects' print literacy skills and abilities appeared to evolve through three sequentlal stages of development which I titled: "Gobbledygook," "Copying," and "Writing." Behaviors Inherent to each stage were present in other stages as subjects' print literacy evolved.

Technological Llteracy. Subjects' technological literacy skills and abilities evolved in an apparent sequential fashion e.g., children learned to print a "hard copy" of their text, clear their text from the screen, and eventually began to learn to save their text.

Intertwining of Print Literacy and Literacy of Technology. Both print literacy and literacy of technology 
evolved simultaneously. Intertwined and integrated with subjects' print literacy development was their literacy of technology development.

Individual Episodes of Growth. Subjects exhibited individual episodes of print literacy development.

Cycling of Print and Technological Behaviors. As subjects became increasingly more sophisticated with print and technology, they continued to employ and integrate less mature print and technological behaviors. They contlnued to mature, but continued to employ earlier learned and developed skills and abilities.

Discussion. Print literacy behaviors were grouped into three categorles: "Gobbledygook," "Copying," and "Writing." These categories are more useful for purposes of description than as distinct stages of development since there is considerable overlap between them. Subjects generally began their literacy growth with word processors in the "Gobbledygook" category, playing and exploring with print. This was followed by their evolving into and towards the categories of "Copying" and "Writing." Typlcally, subjects exhibited two or three of these categorles during a writing session with a word processor. Play and exploration were often Integral components of chlldren's copying and writing. Subjects appeared to continuously cycle through these categories as their print literacy evolved. 
In order to complete their documents, subjects needed to know a certain amount of knowledge about word processor technology. As subjects' print literacy matured, these budding written language users acquired additional knowledge of technology. In addition to discoveries made by themselves or shared by peers, knowledge of technology developed on a need-to-know basis. Adults also shared technological knowledge about word processors.

Subject-specific episodes of print literacy evolution were revealed during the five months of data collection. These print literacy episodes represent individual subject's change in written language sophistication. Subjects exhibited continuous growth during the study in addition to specific episodes of print literacy evolution.

An integral component of this evolution and development are those skills and behavlors titled "Dllly-Dallying." These behaviors--reading, speaking, listening, sharing, manipulation of the technology, and more--evolved simultaneously with writing behaviors. These findings concur with those of Brisk (1985), Heap (1986), and Phenix and Hannan (1984). As with wrlting behaviors and skllls, these behaviors and skills also cycled along the print and technological continuums. Subjects were commonly observed to use written language knowledge to explore the technology and the technology to explore written language. There was a 
continuous intertwining and integration of print literacy and the literacy of technology.

Penci!, Pen and Paper System -- Computer System.

Evolution of Written Lanquage. There were no apparent differences between these systems in relation to individual subject's evolution of written language.

Discussion. Although this was not a comparison study of the pencil, pen and paper system of written language versus the computer system, certain conclusions can be drawn from the findings. Subjects' print literacy growth using a word processor was similar to that of children using pencil and paper. Subjects matured in their own whol istic manner, cycling back to less sophisticated behaviors while simultaneously advancing along their own literacy continuum. These findings do not appear to be dissimilar to Clay's (1975) observations of children using a pencil and paper system: "Observation of children suggests that they do not learn about language on any one level of organization before they manipulate units at higher levels" (p. 19). These findings are also similar to the views of other scholars such as Harste et al. (1984) who write about the evolution of literacy as a continum instead of focusing on specific developmental stages:

Current yardsticks divert attention away from growth and toward 'developmental stages,' which attempt to calculate growth by marking surface level features of conventional form. Such a focus 
draws our attention away from the universals of written language literacy, which operate across language users at all ages and simply express themselves in a variety of alternative forms. It limits our thinking about literacy. Literacy becomes a step-by-step progression of control, not a vehicle for exploring and expanding our world ( $p$. 12).

It became increasingly apparent that subjects exhibited a movement towards mature print literacy in the print literate environment of the writing lab. It was abvious that, for these young children using a word processor, their process of becoming literate was similar to the vehicle (learning written language in a print-laden society) for exploring and expanding worlds as referenced by Harste et al. (1984).

The major difference between these systems lies with the technology of the associated tools. There appears to be much more of an interconnection between print 1 iteracy and the literacy of technology when word processors are used by young children than when they employ pencil and paper. Subjects were learning written language while learning to control technology. While it appears to take only a few writing sessions to learn the technical characterlstics of a pencil, it takes many to learn those of a word processor. It was observed that print and technological literacy behaviors were intertwined as subjects' understanding of literacy evolved. 
Subjects' Time Commitments

Time Commitments. Except for one (see below), each subject exhibited individual time commitments, per session, per month, and per individual episode of print literacy development.

Time to Literacy Growth. No apparent relationship was revealed between time commitments and print literacy growth.

Time Patterns and Trends. There were a variety of time patterns and trends unique to individual subjects. An interesting pattern occurred during the first three months: generally, subjects' time per session increased during the second month and decreased the third month.

Discussion. Time commitments were subject-specific. Except when assigned to a word processor, which was very infrequent, subjects decided how long they would write with a word processor. Since Individual classes were aloted only an hour a day to visit the writing lab, at times, closure of that period and returning to their classroom interfered with subjects' length of time using a word processor. On the basis of time per session, month, and natural episode, each subject displayed individual time commitments.

other patterns and trends of interest related to time commitment also occurred. One is that subjects' average per word processor session committed time increased in February followed by a decrease in March. Four of the five subjects exhibited such a pattern. This general trend may be an 
aspect of children trying a new toy or tool; initially there is a great deal of play which is then incorporated into their repertoire of understanding and therefore later does not receive as much exploration type of attention.

Although there was a continual increase in print literacy and literacy of technology knowledge, tiere was no apparent relationship with time. Except for one, all subjects' print literacy abilities and skills matured while their time commitment to the word processor generally moved up and down or gradually up. One of the subjects decreased her time with a word processor as her print literacy and literacy of technology increased. A number of factors may have contributed to this movement. This particular subject had difficulty becoming a self-sufficlent publisher; she also consistently avoided two of the six word processors and the four she desired were not always available. Again, this trend was subject-specific, dependent upon Individual personality.

\section{Influence of Computer Environment Attributes}

Of the following six findings, the ones of most importance are those related to the printer. The other three findings -- cholce of word processor, choice of screen, and letter preference -- provide teachers with an insight into the use of computers with young children. 
Choice of Monitor Screen Format. Once data were analyzed it became obvious that two of the subjects preferred color displays while three indlcated no preference. Monitor screen format appears to be subject-specific, dependent upon individual personality.

Choice/Avoidance of Word Processor. One subject initially displayed an obvious preference for a specific word processor. Others displayed no preference. Two subjects displayed avoidance behaviors towards two computers. This avoidance was not of the same computers for each subject.

Discussion. Since the computers were situated in a 360 degree arrangement and located in one corner of the room, there was the potential for significant location-related variables. There were south-facing windows on one side of the learning center, two sides opened Into the middle of the room, while the final side was allgned in front of a solid west wall. Peer and adult traffic patterns were also different for each side with the heavlest traffic around the open sides. Wlth subtly different environmental factors associated with each of the computers, would children choose a specific word processor?

One subject displayed a preference for one machine until April 1. After that date, he began to use a varlety of word processors. He was the only subject who displayed such a preference. However, two subjects avoided two computers. They avoided different computers. Their avoidance behaviors 
were consistent throughout the data collection period. Regarding preference and avoidance of computers and the variety of variables which include distance to center of room, student and adult traffic patterns, amount and $k i n d$ of 1 ight striking the screen, and screen display, each subject's computer choice was probably based on his/her own personality. The data do not explain why subjects selected one computer over another.

Use of Printer. There was an obvious desire by subjects to obtain a "hard copy" of their documents.

Print qutput. Subjects printed their own text and often offered to print peers' text. It became apparent that they attempted to become self-sufficient in the printing process.

Printing Skills. Except for one subject, all subjects displayed self-sufficient printing behaviors by the end of the data collection period.

Discussion. From the beginning, subjects printed one or multiple copies of their documents every time they used a word processor. Not only did they print hard copies of their written documents, they often printed when playing or exploring the software. As knowledge of the "print screen" technlque spread among the students, they began to use it to print their formatted documents. In addition, this same technique would be used when they explored software. They would find a specific screen In the edit mode and use "print screen" to produce a hard copy. 
Students began using printers the first week they had an opportunity to use word processors. Initially, children were taken through the printing process both verbally and physically by an adult. Within a short time, often a matter of days, many children were being talked through the printing sequence as they physically manipulated the computer system themselves. By the end of January, within two weeks of computer access and use, one of the subjects was able to print a hard copy by himself.

All subjects displayed growth in their understanding and use of printers. All but one subject became self-sufficient at printing their documents by June. This one exception tried a number of times but appeared to have difficulty with the wholeness of the process, i.e., completing the software procedure at the computer and remembering to turn the network switch to the corresponding number of the computer she was using. She was often assisted by other students as peer assistance and sharing became a commonly observed sight in the word processor center. A second subject, while demonstrating self-sufficient printing, continued to rely on peer or adult assistance throughout the formal data collection period.

But why wasn't everyone able to print his/her own documents after five months of exposure to the process? Each child is an individual with his/her own knowledge, experience, and understanding which $\mathrm{s} /$ he brings to any given 
situation. Although there was an age difference of seven montins (Appendix J) between the two subjects who continued to seek assistance throughout the data collection period, they also appeared to be the least print literate of the five subjects. These two subjects who had minimum success as se!f-sufficient printers were the least print and technologically literate of the five subjects.

Letter Form Preference. Subjects displayed a variety of letter form preference in their writing.

Discussion. When using a word processor, young authors, unaware of English language letter conventions, have the opportunity to explore letter format options and to choose one they want to employ in their documents. It is easy, and subjects were observed to learn early in their contact with word processors, that pushing the caps lock key wlll result in all text being wrltten in either upper or lower case letters. Subjects were also observed to learn early the use of shift keys. With this knowledge, subjects had the option to write in upper case, lower case, mixed case, or in conventional letter format.

When analyzing subjects' written products and graphing the data, it becomes obvious that some children have different letter format preferences. of interest, only one subject used letters in a conventlonal manner. Generally, there was little mixling of upper and lower case letters. To a certain extent this may be a result of subjects' lack of 
knowledge concerning conventional use of upper and lower case letters as well as not being forced by school personnel into the conventionalities of written language. As with so many other physical trends, preferences in use of letters may be a function of individual personality.

OUTHER EINDINGS

\section{Keyboarding}

Initially, subjects were often confused by the display of only upper case letters on the keyboards. This made it difficult for subjects to identify letters of the alphabet.

Discussion. Alphabetic symbols on computer keyboards are in upper case form which meant that subjects were forced to become aware that the standard English Language written alphabet consists of both upper and lower case letters (if they had not acquired this knowledge previously). When a child copied a word or letters--any text which was written in lower case letters--they had to remember and identify the upper case equivalent of that letter on the keyboard in order to write the lower case letter. For these blooming literates, copying and writing became an exercise in association. For some letters, such as $x, x$ or $K, k$, such association is relatively easy. However, for certain letters, such as $G, g$ or $D, d$, association is much more difficult. With certain letters the upper case keyboard symbols caused misunderstandings. The most troublesome 
letter to associate for some children involved the I key. The IBM PCJr. keyboard, as well as Apple IIe and others, have the I key marked in such a manner, basically a straight line "1," that it is often interpreted as a lower case 1. For young children, the sole use of upper case letters on keyboards can cause confusion and frustration as children search for letters. Brisk (1985) recorded similar findings.

An important component to successful movement, exploration, and play was identification of keys. Not only did children learn where keys were located on the QWERTY keyboard, they also learned to identify which keys would produce which symbols. These children no longer had to try to remember how to form specific letters or follow an involved fine motor procedure in order to write, they merely had to identify the correct key and push it. With the use of a word processor, certaln writing skills and behaviors are modifled and changed.

\section{Key Rubbing}

Subjects were often observed to rub the ir fingers back and forth across the keyboard -- not depressing keys, simply rubbing their fingers.

Discussion. Throughout the formal data collection period and also during preliminary research, children often rubbed their $f$ ingers across the keyboard when apparently in thought. This commonly took place when a chlld appeared 
focused on a letter sound or a desired word. Also, chlldren often exhibited this key rubbing behavior when they appeared focused on the next step in the printing procedure, how to clear a certain word from the screen, or how to move a letter back a few spaces. This rubbing of fingers on keys seems similar to the drumming of pencils and pens when writers use such artifacts.

\section{CAI vs. Word Processing Software.}

Subjects appeared to display a preference for the use of word processing software rather than CAI computer Assisted Instruction) software.

Discussion. Within the same writing lab as the word processor learning center was a CAI computer Assisted Instruction) learning center. Children were assigned to this center which focused upon a structured computer software program to teach phonics. There were times when children were interrupted from their writing with a ward processor in order to participate in the CAI center. Children in the CAI setting sat before a programmed computer system and used one finger to push the correct key to recall the correct grapheme (letter) for a corresponding phoneme (sound) or correct graphemes for a requested word. The CAI software primarily used a stimulus-response approach to teaching phonics. As subjects became more proficlent in their print and technological skills they were observed to resist the call to 
stop their involvement in and control of the writing process in order to learn the phonemic make up of their written language from a stimulus-response teaching machine. Subjects and other children were observed to display a preference for word processing over that of CAI software.

\section{Authorship of Word Processed Documents}

It was common to observe that adults who worked in the study setting could identify authors of unidentified printed word processed documents.

Discussion. As previously mentioned, Brisk (1985) found that neither the computer nor printer revealed the real author. From a mechanical print perspective this is no doubt true, similar to the situation with typed or printed pages. Identification of unnamed papers by adults was a common activity in the writing lab. Printed documents without names were often found in the room. Classroom teachers and other school personnel assigned to the writing lab were generally able to determine the authors of unnamed documents. Compositions were usually identifled by style or awareness of the author's topic.

\section{Control}

Subjects appeared to display a desire to, and did, control the word processor system.

Discussion. Subjects continued to explore print and technological literacy throughout the data collection perlod. 
Once they learned how to depress keys, they were able to write letters or words. When a recognized mistake occurred, such as two letters pushed simultaneously or simply the wrong key chosen, one or two pushes of the backspace or delete key cleared the screen of the offending infraction. It was commonly observed that when their first line wrapped, following word automatically moved to the next line, a young writer would try to move the word back up the screen to the line above. Later, when they were able to produce a lot of text and it was scrolled a few 1 ines off the top of the screen in order to make room at the bottom for additional text, children would often inquire about their missing letters and words. Also, subjects discovered early in their word processor experiences that if the cursor were put to the left of a word, that word and all text to the right or below could be moved all around the screen, up, down, left or rlght by using the backspace, delete, arrow, or return keys.

Along with the ease of writing came the ease of text screen creativity. As subjects moved their letters, words, and document about the screen, they were able to input spaces and easily separate letters, words, and lines. Subjects could easily arrange and format text in the manner they desired. If a child had not learned the convention of one space between words, that child would commonly create his/her own space conventions. It was observed in both preliminary and formal data collection periods that this ease of movement 
and unawareness of a space convention allowed subjects to invent systems for separating words. Not unlike childrens play with oral language previously documented (Inhelder in Piattelli-Palmarini, 1980), as subjects continued to use, play, explore, and learn with print and technology, they reinvented and discovered the conventional single space between words of English written language.

Associated with behaviors of play and exploration is the concept of risk taking. Similar to Phenix and Hannan's (1984) findings, the inherent manipulative characteristics of a computer with word processing software supported subjects in their freedom to take risk. This is an extremely important finding in light of Harste's et al. (1984) findings: "... it is via the process of risk-taking that language learning and, hence, growth in literacy occurs" (p. 136). It became easy for a subject to try a letter, word, or space, experiment and play, then clear the screen if the desired outcome was not achieved. Subjects also had freedom to move words and letters around the screen and change their text format or design if desired. Risk taking became part of each subject's writing repertoire as their literacy of technology matured. The freedom to take rlsk with a word processor allowed subjects -- 
to

explore

\&

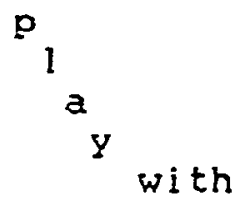

LETTERS,

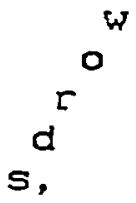

and Print.

\section{Publicness}

Subjects often looked at and read text on others' screens and others often looked at and read text on subjects' screens. This publicness commonly led to verbal interactions and an exchange of knowledge.

Discussion. When documents are produced, elther on screens or hard coples, the text is of standard letter forms which can easily be read by children. Documents produced with standard letter forms are easier to read than handwritten documents. This easy-to-read aspect of computer-related text assisted in the promotion of word-processed documents becoming public. Subjects commonly stood in front of one another's screens and read text or asked and shared copies with their literary colleagues. This publicness supported and led to cooperative behaviors such as sharling, assisting, and volunteering. These cooperative behaviors and the ease of reading standard letter form text, 
also led to colleagual composing as subjects wrote documents with their peers, sharing words and ideas.

\section{Meta-Linquistics}

Verbal Interactlons. Subjects often communicated verbally with peers and adults. Conversations commonly focused on print or technological issues. Meta-linguistic behaviors (use of language to talk about language) were commonly observed.

Sharing of knowledge. It was common to observe children share their knowledge. Subjects commonly shared their knowledge of print literacy and the literacy of technology.

Working With athers. Subjects were often observed to share knowledge with others and work together to solve problems. These cooperative behaviors were commonly observed while subjects worked with both peers and adults.

Discussion. Sharing was not limited to the exchange of documents, written language information, or reading text on another's monitor screen. There were daily requests for help, volunteered assistance, and verbal sharing and dialogue among pairs and groups of children. Such sharing included discussions related to both print 1 iteracy and literacy of technology. There were various questions, e.g., location of certain keys, what letter represents a certain sound, how did you make that happen, how do you spell , how did you print that, what's your story about, and many more. 
Meta-linguistics became a common practice as subjects were observed to share and discuss various aspects of print literacy and literacy of technology.

Throughout this study, subjects continued to evolve along their print 1 iteracy and literacy of technology continuums. Incorporated in this typical kindergarten's curriculum were various print literacy activities which occurred in the classroom. Characteristic large and small group kindergarten classroom activities Included reading to children, singing songs and doing finger plays, exploring with manipulatives and art materials, experimenting and discussing science and social study topics.

Direct group teacher instruction covering print literacy or literacy of technology-related behavlors and skllls was not abserved in the writing lab during the data collection perlod. Throughout the lab, each learning center provided various print and or technologlcal literacy opportunities. Although these children did not receive large group direct instruction in the writing lab, their need for knowledge was facilitated through contact with various adults present in the lab. As previously described, adults Introduced the printing process to children in the writing lab. If a child needed assistance with written language or the technology, they requested assistance from an adult. In a matter of a few iweeks, peers also became facilitators and condults of knowledge. Rather than teachers overwhelming students with 
extraneous knowledge, children rediscovered and reinvented a great deal themselves which they shared with their peers. Generally, subjects received assistance from adults and their peers only as they required and requested it.

\section{Information Age Et iquette}

Subjects learned to check with others before clearing a text screen or printing their documents.

Discussion. In this research setting, where chlldren often had opportunities to choose from a group of word processors, there were incidents of children learning Information Age etiquette. Since computers were networked three to a printer, as children learned the printing process they also learned the etiquette of checking to see if anyone else was in the process of printing. Another social etiquette behavior which children acquired consisted of checking with others when no one was at a computer but text was on the screen. In a setting where there were a number of people using a lesser number of computers, it became necessary to check with others in order to determine the availability of computers. Through social interactions with this limited-access Information Age tool, children were forced into new ways of thinking. 


\section{Cognition}

Cognitive considerations related to print literacy and literacy of technology were observed throughout this investigation.

In addition to the social etiquette Induced ways of thinking, other related trends were also ldentified. Along with key rubbing episodes, previously explained, it became common to observe children who appeared to be in thought. At times, this apparent thought became shared thinking and discussion. If one child had a problem and requested assistance, others would gather around and, in concert, attempt to solve the problem. Thinking and shared problem solving were observed to be important components in subject's evolution of print literacy and literacy of technology.

Problem Solving. Subjects commonly solved or at tempted to solve their indlvidual written language and technology problems. It was common to observe subjects attempting to solve peer problems or vice versa.

\section{Discussion. Two forms of problem solving were} identifled -- one concerns print and the other technology. The one concerning print refers to those cognitive processes a subject employed when s/he ran into difficulty with a word or sound. The subject would often attempt to play with the sounds or words. This was commonly observed and recorded under the subject's "Self Talk." A subject might also ask a peer or an adult for assistance. The other area of problem 
solving concerned associated equipment or, how to solve a technological problem? This occurred quite regularly as a result of the problem created when children reached across the top of a printer in order to tear off a sheet of paper. Often, when stretched across a printer, the child accidently pushed one of the top buttons, effectively turning the printer off for everyone else. The next child to print had to figure out what to do. Generally, the next child to print did not run into difficulty until s/he had progressed to the final steps of the printing process and nothing happened. Here, as with print literacy problems, if subjects did not solve the problem themselves they would often request asslstance from a peer or an adult. Subjects shared problem solving.

Thinking about Writing Tools. New ways of thinking related to the evolutionary intertwining of print literacy and literacy of technology developed.

Discussion. As subjects became more aware of the tool's capabilities, their understanding of lts utilization in their writing changed. Subjects were inventing and rediscovering new print and technological thoughts. The following few examples are new ways of thinking about wrltten language when using a word processor. Following their initial exposure to word processors, subjects rediscovered the English written language convention of space between words. When utilizing Industrial Age writing implements and those of previous 
literate Ages, writers leave spaces as they write. In using word processors, subjects learned to physically input a space with a key stroke. Subjects also learned to print a hard copy of their ephemeral text. They discovered that light on a monitor screen was something they could not smudge, al though they often touched the screen as they reread their documents. Subjects also discovered the malleability of word processor documents as they moved text around a screen. In time, they developed a degree of realization that they had many opportunities to place text in a variety of different locations. By the end of the data collection period, subjects had learned that their screen text could be saved on a disk and retrieved at another time for further writing. CHILDREN

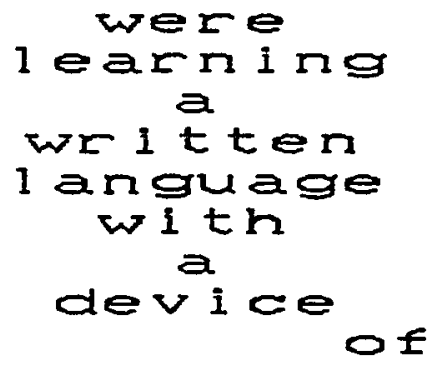

NEW

AGE.

An outgrowth of young children using these Information Age machines was their learning and cognitive understandings of software, computers, and printing. For example, during one of his opportunities to print one subject followed a "To Clear" teacher-made direction card and cleared his text instead of printing it. This subject, at the young age of 
six, was learning the Importance of manlpulating software correctly in order to produce a hard copy of his document. Developing an understanding and appreciation for cautlous computer manipulation as a young child is cognitively important for members of the Information Age. Losing a two line story at age six allows a young child the opportunity to acquire an awareness of technology early in life so that later, when s/he is working on a major paper or important project, s/he does not accidently erase or lose an entire document. Experiences such as these may allow young children of the Information Age to mature with a cognitive understanding that computers are helpful tools and machines which they can control and need not fear.

Often, while observing subjects writing, there was an apparent sense of total involvement in the word processor center. Not only were both hands involved in a physical sense, so were eyes, ears, and mouths as subjects shared, assisted, and talked to themselves and others during the writing process. It appeared that cognitively, subjects were not only involved in recall of information, they were also applying, analyzing, synthesizing, and evaluating their work. While writing, subjects constantly reread their text, wrote or sounded out the next word, figured out where they were, what they were doing, and where they were golng, continuing to use many sophisticated cognitlve behaviors as they wrote. 
During this study, subjects were abserved to mature along individual print 1 iteracy and literacy of technology continuums. Subjects' print and technological abilities and skills became more sophisticated as they interacted with peers and adults within the writing lab environment. Among the many findings are those which support the concept that young children, using word processors, are becoming cognitively prepared for the Information Age.

Printing. Printing is apparently another important cognitive process when writing with a word processor.

Discussion. In time, subjects learned two methods for producing a hard copy of their text. They first learned the previously explained normal software-controlled process. The second learned and easier method is the computer-controlled "print screen" technique. The first method produced documents in the manner in which they were written. If an author used the space bar, backspace, and arrow keys when manipulating cursor and text, the hard copy document of ten appeared quite different from the screen-displayed text. In order to obtain a formatted copy as originally written, deslgned, and screen displayed, it was necessary to use the "print screen" method. If using "print screen," the hard copy also included extraneous text of the software screen display. By the end of the data collection perlod, subjects knew of two printing methods and chose between them when producing a hard copy. 
Neither of these printing methods required subjects to understand how light images moved from a monitor screen to become ink dots on paper at a printer. However, in order to work the computer printing system, subjects had to understand that these computers were networked with printers and that a dial at a switch box had to be turned, linking printer and computer, in order to successfully print one's text. Once the dial was turned, then a printing method could be initiated and the process completed.

No matter which printing method was employed, subjects always printed a hard copy of their prose. Printing was not limited to one copy but often entailed multiple copies which were shared with peers, adults, and family members. When asked, or as a result of their own initative, children would share their printed prose by reading it aloud to others. The opportunity to print their work was an important feature of the word processor center.

Keyboarding. Another cognltive and kinesthetic consideration relates to the effective use of a word processor keyboard.

Discussion. Often, subjects appeared to naturally attempt to employ both hands in their play and writing. No doubt, some use of "both hands behavior" was an imitation of others they had seen write with a two handed writing device. Subjects were observed numerous times to use their right hand on the right side of the keyboard and thelr left hand on the 
left side. Some subjects appeared extremely intent at keeping both hands on either side of a keyboard as they wrote. In addition some subjects, both in the preliminary and formal research, were observed attempting to invent or discover a "home row keys" method. This use of both hands and all fingers is cognitively and kinesthetically a new understanding for these young children who in the recent past have evolved a handedness and employed it for writing with a pencil and paper system.

\section{Gender Differences}

Subjects represented both genders in this study. The only apparent difference between the genders during the formal data collection period was their previously mentioned segmentation as they continued to evolve along their print literacy and literacy of technology continuums.

Discussion. Although no significant gender differences occurred during the formal research period, one of interest took place during the preliminary investigation.

Observations were conducted in two kindergarten classes during the preliminary investigation. In the fourth month of the preliminary research it was discovered that all students who could print on their own, except for one, were boys. After analyzing this phenomenon, it was determined that this situation had unintentionally evolved. As glrls finished their documents, they would generally continue to sit at the 
computers, raise a hand, and wait for an adult to print their document for them. Meanwhile, many boys had been following the printing process since the first day. Watching and listening, they learned the printing process and took control of the equipment. When finished writing, boys would automatically print their own documents and work with anyone else who required their assistance.

Within the confines of the word processor center environment, there were no apparent reasons for this gender disparity in the operation of printers. Even though one of the kindergarten teachers was an ardent feminist, there were many cumulative social variables within our culture affecting the development of her students during their first five years of 1 ife. In addition, the necessity is apparent that educators continue to observe and evaluate their work with children and the educational environment.

During the formal data collection period of this Investigation, educators working with children in the writing lab were aware of the previous year's gender dlfferences. Once aware of the gender differences, personnel made a conscious commitment to include girls in the printing process. No doubt due to this awareness and the commitment exhlbited by personnel, obvious gender differences did not revel themselves as they had the previous year. 


\section{CONCLUSIONS}

In western societies, young children of the late 20 th century experience daily contact with tools of the Information Age. For educators, this investigation provides a foundation of empirical knowledge for curriculum and instruction of the Information Age. There were a number of conclusions drawn from the findings of this investigation. However, certain conclusions are more noteworthy than others for school decision makers. These distinctive conclusions can be separated into two categories related to school adminlstration, management decisions, and curriculum and instruction decisions. Of these conclusions, a number $f$ it both categories.

Educational decision makers will find it valuable to study the findings of this research along with the findings of psychologist and others investigating the concept of "locus of control." The young subjects of this Investigation had the opportunity to control a tool of the Information Age through their use of word processing software. It was common to observe that children prefer the opportunity to work and play with (control) a word processor rather than responding to the dictates (control) of a computer programmed with CAI software. This is of particular importance in regard to many educators' and others' expectations for low socioeconomic students and young children. 
Associated with the placement, status, and purchase of computers and software in education is the finding that print literacy and the literacy of technology evolved simultaneously. Language arts and computer literacy may not require the expenditure of funds for separate subject tools and resource materlals. Computers are tools of and for literacy as pens and pencils have been in previous ages. In addition, although there are new ways of viewing the printed word, it was found that paper was an integral and important aspect of the use of a word processor. It was found that children could both control a computer system to print a hard copy of their writing and that they apparently desired a peintout.

This study supports the theory of individualized evolution of print literacy. Each subject displayed a continuum of developmental literacy behaviors. As subjects acquired more sophlsticated behaviors they continued to also employ earller learned behaviors. This recycling of behaviors occurred with both print literacy and literacy of technology behaviors. Subjects were observed to intertwine and integrate these two forms of 1 iteracy as they used word processors. In addition, each subject was observed to evolve within his/her own time frame. In relation to the emphasis on wholistic learning and individualized instruction during recent years, these findings demonstrate that tools of the 
Information Age (microcomputers) can support these educational concepts as readily as Industrial Age tools. Whereas writing was generally a private act in previous ages, this study demonstrates the Information Age phenomenon of "publicness." Children commonly looked at one another's monitor screens and commented on each other's writing. This writing/reading connection often led to metalinguistic behaviors as children discussed print literacy issues or issues of technology and solved associated problems. These social and intellectual interchanges and problem-solving behaviors were not limited to opportunities growing from publicness, but at times grew out of colleagual discussion initated by one child seeking assistance from others. An additional outgrowth of these discussions was the learning of Information Age etiquette. Findings of this study demonstrate that the social interchange of information among students and staff may be an inherent aspect of computer systems where allowed to occur.

All of these findings point to the conclusion that in a print and technology-laden society, young children evolve an understanding of print literacy and literacy of technology. It is important that educators recognize this common form of cultural evolution and facilitate its growth through appropriate administrative, Instructional, and curricular decisions.

The following are speciflc conclusions. 
Young Chll dren Are Capable of Using A Word Processor

Young children are capable of learning to use and employing a word processor in their writing. As they use a word processor their print literacy as well as literacy of technology continues to mature.

\section{Young Children Can Control A Word Processor}

Young children desire to control the computer system. They want to become self-sufficient at printing and take contral as soon as possible. Thls sense of control is also observed in children's writing process and their printed documents.

\section{Young Children Practice Social Interactions}

Dispelling the fear of isolation related to childrens' use of computers, young children are often involved with others when using a word processor or when a word processor is in the immediate environment. Their dialogue commonly focuses on print literacy or literacy of technology. Young children's social behaviors often encompass physical as well as verbal assistance to their peers, commonly through the sharing of print and technological knowledge.

\section{Young Children Are Problem Solvers}

Young children commonly solve or attempt to solve questions of written language and technology problems. 


\section{Young Children Are Learning Information Age Etiquette}

Young children can learn to take turns in order to print in a computer network system. They are also learning to ask if others are finished with a computer if text is on the screen before using a particular computer.

\section{Provide Printers}

Where word processing will be an integral component in the design of computer use in schools, it is important to include printers in the computer system.

\section{Modify Computer Keyboards}

Initially, young children have difficulty with a typical "QWERTY" keyboard. Consider the inclusion of upper and lower case letters on the keys of computer keyboards used by young children.

\section{Educators' Awareness}

It is important that educators, including those in administration, be aware of children's knowledge of the Information Age and their utillzation of associated tools. This awareness is particularly important in planning for the present and future education of our nation's children. 


\section{BI BLIOGRAPHY}

Adams, A. (1985). Talking, listening and the microcomputer. In D. Chandler, \& S. Marcus (Eds.), Cemputers and literacy. (pp. 41-55). Philadelphia, PA: Open University Press.

Agnew, N. M., \& Pyke, S. W. (1969). The science game. Englewood Cliffs, NJ: Prentice-Hall, Inc.

Alessi, S. M., \& Trollip, S. R. (1985). Computer-Based instruction methods and development. Englewood, NJ : Prentice-Hall, Inc.

Allen, D. (1973). (ed.) Early years at school. Iondon, England: Britlsh Broadcasting Corporation.

Allen, R. V. (1976). Lanquage experiences in communication. Boston, MA: Houghton Mifflin Company.

Almy, M. (1976, January). Piaget in action. Young Children. 31(2), p. 93-96.

Al twerger, B., Edelsky, C. \& Flores, B.M. (1987, November). Whole language: What's new? The Readlng Teacher. $41(2)$, p. 144-154.

Anderson, A. B., \& Stokes, S. J. (1984). Social and Institutional influences on the development and practice of 1 lteracy. In Goelman, H., Oberg, A., \& Smith, F. (Eds.). (1984). Awakening te literacy (pp. 24-37). Portsmouth, NH: Heinemann Educatlonal Books.

Anderson, R. C., Hiebert, E. H., Scott, J. A., \& Wilkinson, I. A. G. (1985). Becoming a nation of readers. The Report of the Commission on Reading. Washington, DC: The National Institute of Education.

Anderson-I nman, L. (1986, November). The reading-writing connection: $\mathrm{Cl}$ assroom application for the computer, Part I. The Comput ing Teacher. $14(3)$, p. 23-26.

Anderson-Inman, L. (1987, March). The readlng-wrlting connection: Classroom application for the computer, Part II. The computing Teacher. $14(6)$, p. 15-18. 
Angus, L. B. (1986, November). Developments in ethnographic research in education: From interpretive to critical ethnography. Journal of Research and Development in Education. 2Q $(1)$, p. 59-67.

Anker, D., Foster, J., McLane, J., Sobel, J., \& Weissbourd, B., (1974, May). Teaching chlldren as they play. Young Children. 29(4), p. 203-213.

Anselmo, S. \& Zinck, R. A. (1987, March). Computers for young chlldren? Perhaps. Young Chlldren. 42(3), p. 22-27.

Appl ebee, A. N. (1982, March). Looking at writing. Educational Leadership. $39(6)$, p. 458-462.

Applebee, A. N. (1977, December). Writing across the currlculum: The London projects. ERIC/RCS Report. Engl 1sh Journal, p. 81-87.

Arms, V. M. (1983, Spring). The computer and the process of composition. Pipeline, p. 16-18.

Atkins, C. (1984, November). Writing doing something constructive. Young Chlldren, $40(1), 3-7$.

Baghban, M. (1984). Our daughter learng to read and wr ite. Newark, DE: IRA.

Baring-Gould, W. S., \& Baring-Gould, C. (1967). The annotated mother goose. New York, NY: Times Mirror.

Barron, R. W. (1985). Interactlons between spelling and sound in literacy. In D. R. Olson, N. Torrance, \& A. Hlldyard (Eds.), Llteracy, lancuage, and learning (pp. 368-388). Cambr Idge, England: Cambrldge University Press.

Begley, S. \& Llef, L. (1986, November 10). The way we were. Newsweek. p. 62-72.

Beil, N. T. \& Warner, J. W. (1986, August). Desktop publishling: A new frontler for instructional technologists. I.H. E Technological Hoclizens In education Journal. 14(1), p. 71-73.

Bell, W. (1983, Winter). What to do 'til the word processor comes. Virginla Enalish Journal. 33(2) p. 20-22.

Blckel, L. L. (1985), Word processing and the integration of reading and writing instruction. In $J$. L. Collins, \& E. A. Somners (Eds.), Writling en-line (pp. 39-46). Upper Montclair, NJ: Boyton/Cook Publishers, Inc. 
Biddle, B. J. ( 1967 , June). Methods and concepts in classroom research. Revlew of Educational Research. 37(3), p. 337-357.

Bingham-Newman, A. M., \& Saunders, R. A. (1977, May). Take a new look at your classroom with piaget as a guide. Young Chlldren. 32(4), p. 62-72.

Bissex, G. L. (1980). Gnys at wrk: A chlld learns to wrlte \& read. Cambridge, MA: Harvard University Press.

Bissex, G. L. (1984). The chlld as teacher. In H. Goelman, A. Oberg \& F. Smith (Eds.), Awakenlng to literacy (Pp. 87-101). Portsmouth, NH: Heinemann Educational Books.

Blask, A. S. (1986, February). Home-School connection. Family Computing, p. 6-7.

Boone, R. A. (1985, August). Word processing and the writing pracess. Paper presented at the 4th Annual Meeting. Extending The Human Mind: Computers In Education. Eugene, OR.

Boorstin, D. J. (1983). The Discoverers. New York, NY: Random House.

Bork, A. ( 1987 , May). Computer networks for learnlng. T.H.E Technological Horizons In Education Journal. 14(9), p. 68-71.

Boudrot, T. E. (1986, February). The secrets to teaching word processing or the legacy of Morris $Q$. Moneybucks. Teaching and Computers, p. 18-23.

Boyan, N. J. ( 1981 , February). Follow the leader: Commentary on research in educational administration. Educational Researcher. p. 6-21.

Bozeman, W. C., \& House, J. E. (1988). Mlcrocomputers in education: The second decade. T.H.E. Techneloglcal Heclzons In Education Jeurnal. 15(6), p.82-86.

Bradley, B. ( 1983 , September). Machines don't dehumanlze, People do. Classroom Computer Learning. 2(1), p. 20-28.

Bradley, V. N. (1982, October). Improving students' writing with microcomputers. Language Arts, 59(7), p. 732-743.

Brady, H. (1985, November/December). Hang on to the power to imagine. an interview with Joseph Welzenbaum Classroom Computer Learning. 6(3), p. 24-27. 
Branan, K. ( 1984 , October). Moving the writing process along. Learning 13(3), p. 22-26.

Brenner, B. (1985). A word processor in the famlly. The Bank Street Seftware Letter. New York, NY: Media Group.

Brent, D., MacMillan, S., \& Zavala, B. (1985, October). Effective integration of computer technology into a secondary school: Writing across the curriculum. THE Technologlcal Horizons In Education JOURNAL. $13(3), \mathrm{p}$. 103-106.

Bridges, E. M. (1982, Summer). Research on the school administrator: The state of the art, 1967-1980. Educational Administratlon Quarterly. 18(3). p. 12-33.

Bridwell, L. S. \& Duin, A. (1985). Computers as weiting medium and research tool. In J. L. Collins, \& E. A. Sommers (Eds.), Writing en-line (pp. 115-121). Upper Montclair, NJ: Boyton/Cook Publlshers, Inc.

Bridwell, L. S., \& Ross, D. (1984). Integrating computers into a writing curriculum; or, buying, begging, and bullding. In $W$. Wresch (ed.), The computer In Composition Instruction: A Writer's Toel (pp. 107-119). Urbana, IL: Natlonal Councll of Teachers of English.

Brisk, M. E. (1985, Spring). Using the computer to develop i teracy. Equity and Chelce, 1(3), p. 25-32.

Britton, J. (1979). Learning to use language in two modes. In N. R. Smith \& M. B. Frankl in (ed.), Symbelic Functioning In Childheed (C. 11). Hlllsday, NJ: Lawrence Erlbaum Associates.

Brookover, W. B., Beady, C. H., Elood, P. K., Schneider, J. M., Schweltzer, J. H., \& Wi senbaker, J. M. C1978, Spring). Elementary school soclal cilmate and school achievement. American equcational research iournal, 15(2), p. 301-318.

Brookover, W. B., Beamer, L., Efthim, E., Hathaway, D., Lezotte, L., Mlller, S., Passal acqua, J., \& Tornatzky, L. (1982). Creating effectlve schools. Holmes Beach, FL: Learning Publications, Inc.

Bruce, B., Michaels, S., \& Watson-Gegeo, K. (1985, February). How computers can change the writing process. Lancuage Artg, 62(2), p. 143-149. 
Bruner, J. (1984). Language, mind, and reading. In $H$. Goelman, A. Oberg \& F. Smith (Eds.). (1984). Awakening to literacy. (pp. 193-200). Portsmouth, NH: Heinemann Educational Books.

Burling, R. (1976, March). Poor spellers of the world unlte! Learning. $4(7)$, p. $76-78$.

Burns, H. (1983, Spring). Computer-assisted prewriting activities: Harmonics for Inventlon. Pipeline, p. 7-9.

Burrows, A. T., Jackson, D. C., \& Saunders, D. O. (1984). They all want to wrlte. Hamden, CT: Library Professional Publications.

Butler, D. (1975). Cushla and her books. Boston, MA: The Horn Book.

Calkins, L. M. (1986, January). How reading can insplre writing: One teacher's experience with a workshop approach. Learning. 14(5) p. 68-72.

Calkins, L. M. (1985, Fall). 'I am one who writes'. American Education. 21(3), p. 6 .

Calkins, L. M. (1983). Lessons from a child, Portsmouth, NH: Heinemann Educational Books.

Calkins, L. M. (1986). The art of teaching writing. Portsmouth, NH: Helnemann Educational Books.

Caster. T. (1983, January). The use and effect iveness of computers in the elementary classroom. Paper presented at the Annual Study Conference of the Georgia Assoclation for Chlldhood Education International. Athens, GA.

Cazden, C. B. (1982). Language and learning to read. In C. B. Cazden (ed.), Lanquage In early Childhood Educat ion. Washington, D.C.: Natlonal Association For The Education of Young Chlidren.

Chandler, D., \& Marcus, S. (Eds.). (1985). Computers and Llteracy. Phlladelphla, PA: Open Universlty Press.

Chomsky, C. (1971, March). Write first, read later. Chlldhood Education. 47(6), P. 296-299.

Chrlstensen, L.. \& Others (Eds.). (1983). A guide to using the computer in the writing process, Wisconsin Unlversity, Madison, WI: Department of Currlculum and Instruction 
Clark, D. I., Lotto, L. S., \& McCarthy, M. M. (1980). Secondary source study of exceptionallty in urban elementary schools. In The phi delta kappa study of exceptional urban elementary schools, why do some urban schools succeed? (pp. 144-210). Bloomington, IN : Phi Del ta Kappa.

Clark, M. M. (1984). Llteracy at home and at school: Insights from a study of young fluent readers. In Goelman, H., Oberg, A., \& Smith, F. (Eds.). (1984). Awakening to 1iteracy. (pp. 122-130). Portsmouth, NH: Heinemann Educational Books.

Clark, M. (1985). Young writers and the computer. In D. Chandler, \& S. Marcus (Eds,), Computers and literacy. (pp. 12-25). Philadelphla, PA: Open University Press.

Clay, M. M. (1975). What did I wrlte? Portsmouth, NH: He inemann Educational Books.

Clements, D. H. (1987, November). Computers and young children: A review of research. Young Children. 43(1), pp. 34-44.

Collins J. L., \& Sommers, E. A. (1984, September). What research tells us about composing and comput ing. Paper presented to the Computer Educators League. Buffelo NY. p. 22.

Collins, J. L., \& Sommers, E. A. (1985). Writing an-line. Upper Montclair, NJ: Boynton/Cook Publishers, Inc.

Costa, A. L. \& Marzano, R. (1987, October). Teaching the language of thinking. Educatlonal Leadershlp. $45(2), P$. 29-33.

Crichton, M. (1983). Electronle life: How to think about computers. New York, NY: Alfred A. Knopf.

Crist, W. (1984, Winter). Teachling writing through word processing and the rhetoric of composition. Computers in the Schools, 1(4), ISSN: 0738-0569.

Cuban, L. (1983, June). Effectlve schools: A frlendly but cautlonary note. Phl Delta Kappan. 64(10), p. 695-696.

Culbertson, J. A. ( 1983 , Summer). Leadership horlzons in education. Educational Adminlstratlon Quarterly. 19(3). p. 273-296. 
Dalute, C. (1984). Can the computer stimulate writers' inner dialogues? In $W$. Wresch (ed). The Computer In Composition Instruction A Writer's Tool, (pp. 131-139). Urbana, IL: National Council of Teachers of English.

Daiute, C. (1985). Writing \& computers. Reading, MA : Addlson-Wesley Publishing Company.

Daiute, C. (1983, Marah/April). Writing, creativity and change. Shlldboad Education. 59(6), p. 227-231.

Datz, T. T., \& Datz, F. L. (1984, May) The processed word. Softalk for the IBM Personal Computer, p. 88-100.

Davis, F. R. A. (1977, March). Writing development in some Brltish infant schools. Young Children. 32(3), p. 55-53.

DeFord, D., \& Harste, J. C. (1982, September). Child language research and curriculum. Lanquage Arts, 59(6), p.590-600.

Denson, H. (1985, September). Can't prove it, but it's true: word processing makes 1 ife easier for students and instructors. TechTrends. 30(4), p. 31-34.

Diesing, P. (1983, Fourth Quarter). Ethnography. The English Record $34(4)$, p. 2-5. New York State Engl ish Council.

Dillon, D. (1985). The dangers of computers in literacy education: Who's in charge here? In D. Chandler, \& $S$. Marcus (Eds.), Computers and literacy. (pp. 86-107). Philadelphla, PA: Open Unlversity Press.

Donaldson, M. (1978). Children'smind's. New York: W.W. Norton and Company.

Donaldson, M. (1984). Speech and writing and modes of learning. In H. Goelman, A. Oberg \& F. Smith (Eds.). (1984). Awakening to literacy. (pp. 174-184). Portsmouth, NH: Helnemann Educational Books.

Duln, A. H. \& Graves, M. F. (1986). Effects of vocabulary instruction used as a prewriting technlque. Journal of Research and Development in Education. 20(1), p. 7-13.

Dullng, R. A. (1985). Word processors and student writing: A study of thelr impact on revislon, fluency, and quality of wrlting. Dlssertatlon Abstracts Internatlonal, 46, 1783-1875A. CUniversity Microflims Iniernational. 46/7, 1823) 
Dyson, A. H., \& Gemlshi, C. (1982, Eebruary $)$. Whatta ya tryln' to write? writing as an interactive process. Lanquage Arts, 59(2). p. 126-132.

Eagan, A., \& Wlllson, M. A. (1984, Winter). What does the teacher need to know? The Pointer, 28(2), p. 27-31.

Educators' Report (1986, Winter). Compositlon and computers: A team. IBM Educational Systems, Atlanta, GA: Author.

Educators' Report (1986, Winter). Natlon's capltal finds 'roots' in writing to read. IBM Educational Systems, Atlanta, GA: Äutinor.

Ehrl lch, D. B. (1985). A study of the word processor and composing: Changes in attitude and revision practlces of inexperienced student writers in a college composition class. Dlssertation Abstracts International, 45, 2080-2131A. (University Microfilms International. 45/7, 2081 )

Eisensteln, E. L. (1985). On the printing press as an agent of change. In $D$. R. Olson, N. Torrance, \& A. Hildyard (Eds.), Literacy, lancuage, and learning (pp. 19-33). Cambridge, England: Cambridge University Press.

Elser, L. (1985, February). Can kids outgrow word processing programs? Classroom Computer Learning, p. 52-55.

El lermeyer, D. ( 1988 , January). Kindergarten readling programs to grow on. The Readling Teacher. 41(4), p. 402-405.

Elbow, P. (1973). Writing without teachers. New York, NY: Oxford University Press.

Emans, R. (1986). Theory, practlce, and research in literacy learning. In D. R. Tovey, \& J. E. Kerber, (Eds.). Roles In Llteracy learnlng. (pp. 135-144). Newark, DE: International Reading Association.

Erlckson, D. A. (1979, March). Research on educational administration: The state-of-the-art. Educational Researcher. I(3), p. 9-14.

Evans, C. (1982, April-May). An Invitation to the (near) future. Teday's Education. $71(2), p .12-15$.

Evans, C. (1979). Themicremillennilum. New York, NY: The Viklng Press. 
Ferreiro, E., \& Teberosky, A. (1982). Literacy before scheoling (K. G. Castro.). Exeter, NH: Helnemann Educational Books. (Original work published 1979)

Ferrelro, E. (1985). Llteracy development: A psychogenet ic perspective. In D. R. Olson, N. Torrance, \& A. Hildyard (Eds.), Literacy, lanouage, and learnlng (pp. 217-228). Cambr Idge, England: Cambrlage Universlty Press.

Ferreiro, E. (1984). The underlying logic of I Iteracy development. In H. Goelman, A. Oberg \& F. Smith (Eds.). (1984). Awakening to literacy. (pp. 154-173). Portsmouth, NH: Heinemann Educational Books.

Fetterman, D. (1980, Fall). Ethnographlc techniques in educational evaluation: An illustration. Journal of Thought. p. $31-48$.

Fetterman, D. M. (Ed.). (1984). Ethnegraphy in educational evaluation. Beverly Hills, CA: Sage Publications.

Flelds, M.V. \& Hlllstead, D.V. (1986, May). Reading begins with scribbling. Princlple. 65(5), p. 24-27.

Elnnan, C. R. (1982). The ethnography of chlldren's spontaneous play. G. Spindler, (Ed.). Doing the ethnography of school lng. New York, NY: Holt, Rinehart and Winston.

Fisher, G. (1983, February). Word processing - Will it make all kids love to write? Instructor. XCII(5), p. 87-88.

Fisher, R. J., \& Flsher, R. L. (1985, September). Reading, writing \& science. Sclence and Chllaren, $23(1), p$. 23-24.

Fondacaro, R. \& Higgins, E. T. (1985). Cognitive consequences of communication mode: A social psychological perspective. In D. R. Olson, N. Torrance, \& A. Hildyard (Eds.), Literacy, language, and learning (pp. 73-101). Cambr ldge, England: Cambridge University Press.

Forester, A. D. $(1980)$. Learning to spell by spelling. Theory Inte Practlce, XIX(3), p. 186-193.

Fosnot, C. T. (1984, Winter). Medial and technology in educatlon: A constructivist view. Educatlonal Communteation \& Technology. 32(4), p. 195-205.

Frankl In, J. B. (1973, November). Non-verbal representation In young chlldren: $A$ cognitive perspective. Young Chlidren. $24(1)$, p. 33-53. 
Frase, L. T. \& Diel, M. ( 1986 , October). UNIX writer's workbench: Software for streamlined communication. THE Technological Hor lzons In JOURHAL. 14(3), p. 74-78.

Frobel, F. (1891). Mother's songs games and stories. (F. Lord, \& E. Lord, Trans.). Chicago, IL: Alice B. Stockham \& $\mathrm{Co}$.

Froese, V. (1978, October). Understanding writing. Language Acts, 55(7), p. 811-815.

Gall agher, B. (1985). Microcomputers and word processing proarams. City Unlversity of New York, NY: The Instructional Resource Center.

Gallagher, B. (1985, April). Computers, word processing, and the teaching of writing. Research In Word Processing Newsletter, $3(4)$, p. 1-5.

Gentry, J. R. (1985, November/December). Getting kids to write in kindergarten and first grade. Early Yearg. $p$. 34-35.

Georgas, N. (1984 October). How Word Processing Can Help Your $\mathrm{Ki}$ ids. Personal Computing. 8z(10), p. $132-136$.

Gesell, A., Halverson, H. M., Thompson, H., Ilg, F. L., Castner, B. M., Ames, L. B., \& Amatruda, C. S. (1940). The first five years of life: The preschool years. New York, NY: Harper \& Row Publ ishers.

Gl llesple, T. (1985, November). Becoming your own expert--teachers as writers. Network Newsletter. The National Writing Project, $8(1)$, p. 1-2.

Goelman, H., Oberg, A., \& Smith, F. (Eds.). (1984). Awakening to Ilteracy. Portsmouth, NH: Hel nemann Educational Books.

Goodman, K. (1986). What's whole in whole lancuage? Portsmouth, NH: Heinemann.

Goodman, Y. (1984). The development of Initlal literacy. In Goelman, H., Oberg, A., \& Smith, F. (Eds.). (1984). Awakenling to literacy. (pp. 102-109). Portsmouth, NH: Helnemann Educational Books.

Graves, D. H. (1984). A researcher learng to write. Portsmouth, NH: Heinemann Educational Books.

Graves, D. H. (1983). Writ Ing: Teachers and children at work. Portsmouth, NH: Helnemann Educational Books. 
Green, J. O. ( 1984 , March). Word processors and wrlting: An interview with Donald Graves. Clasgrom Computer

Learning, p. 20-23.

Gregory, L. L. (1980). Synthesis of the case studies. In The phi delta kappa study of exceptional urban elementary schools, Why do some urban schools succeed? (pp. 132-141). Bloomington, IN: Phi Delta Kappa.

Guba, E. G., \& Lincoln Y. S. (1981). Effective evaluatlon, San Francisco, CA: Jossey-Bass Publishers.

Gunderson, I. \& Shapiro, J. (1988, January). Whole language instruction: Writing in 1 st grade. The Readling Teacher. $41(4)$, p. $430-437$.

Guttinger, H.I. (1986, Spring). Writing to read: it's a gold-medal winner. Educators' Report, p. 17-19.

Hall, E. T. (1959). The sllent language. Garden City, NY: Doubleday and Company, Inc.

Halpern, J., \& W. Llggett. S. (1984) Computerg \& composing: How the new technologies are changing writing. Carbondale, IL: Southern Illinois University Press.

Harste, J. C., Woodward, V. A.. \& Burke, C. L. (1984). Lanquage starles \& literacy lessons. Portsmouth, NH: Heinemann Educatlonal Books.

Hart, L.A. (1986, May). A response: All "thinking" paths lead to the brain. Educational Leadership, $43(8), p .45-48$.

Hayes, D., \& Plaskon, S. P. (1982, Winter). Basing language arts Instruction on what chlidren know about words. Educational Horlzons, p. 73-78.

Heap, J. L. (1986, March). Collaboratlve practices during computer writing in a first grade classroom. Paper presensed at the annual meetling of the Amerlcan Educational Research association, San Franclsco, CA.

Heath, S. B.. \& Thomas, C. (1984). The achlevement of preschool literacy for mother and child. In Goelman, H., Oberg, A., 8. Smith, F. (Eds.). (1984). Awakening to literacy. Portsmouth, NH: Heinemann Educational Books.

Heffron, $X$. (1986, November). Literacy with the computer. The Reading Teacher. ( 40 ) 2, p. 152-156. 
Hennings, D. G. (1981, January). Input: Enter the word-processing computer. Ianouage Arts, $58(1), p$. 18-22.

Hertz, R. M. (1983, September). Problems of computer-assisted instruction in composition. The Computing Teacher. $11(2)$, p. $62-64$.

Hirsch, E. D. (1987). Cultural Literacy. Boston, MA: Houghton Mifflin Company.

Hirsch, E. D. Jr. (1982) Some principles of composition from grade school to grad school. In G. Hillocks, Jr. (Ed.), The Engllsh Curciculum under Eire (pp. 39-52). Urbana, IL: National Council of Teachers of English.

Holdaway, D. (1979). The foundations of literacy. Sydney. Australla: Ashton Scholastic.

Hol daway, D. (1984). Stabllity and change in literacy Learning. Portsmouth, NH: Heinemann Educational Books.

Huber, I. N. (1985, October). Through Plaget's eyes. Classroem computer Learning. ㄷ( 2$), p .39-43$.

Humes, A., Cronnel 1, B., Lawlor, J., \& Gentry, L., (1982, November). Computer utllization in composition Instruction specifications. (Final Report). Los Alamltos, CA: Southwest Reglonal Laboratory For Educatlonal Research and Development.

Jackson, D. (1981). The story of writing. New York, NY: Taplinger Publishing Company.

Jacob, E. (1984). Learning literacy through play: Puerto Rican kindergarten chlldren. In Goelman, H., Oberg, A., \& Smith, F. (Eds.). (1984). Awakenlng to literacy. Portsmouth, NH: Helnemann Educatlonal Books.

Jacoby, A. (1984). Word procegsing with the elementacy school student - $A$ teach ing and learning exper lence gor both teachers and students. Paper presented at Spring Conference of the Delaware Valley Writing Council and VIllanova Universlty's Engl Ish Department, Phlladaphlla Public Schools.

Joslin, E. (1986, March). The computer as a wrlting tool. The Computing Teacher. 12(6), P. 16-19.

Jowett, B. (1953). The Dlaloques of Plato. (4th ed.). (Vols. 1-42. Oxford: England. The Clarendon Press. 
Kami 1, C. (1985, September). Leading primary education toward excell ence. Young Children, $40(5), p$. 3-9.

Kaplan Michael H. Galbreath Diane \& Vargas Carollne, "Ethnographlc and Qualitative Methods in Educatlonal Research: A Selected Annotated Bibliography," Mid-Atlantic Center for Community Education, University of Virginia, Charlottesville, Virglnla, 1980 p. 63.

Kelly, P., \& Self, W. (1983, Winter). Computers in a Writing project. Virginia English Jeurnal, 33(2), p. 11-15.

Kerchner, L. B., \& Kistinger, B. J. (1984, Fall). Language processing/word processing: Written expression, computers and learning disabled students. Learning Disability Quarterly, 7 , p. 329-335.

Kllllan, J., Nelson, J., \& Byrd, D. (1986, August/September). Child's play: Computers in early childhood programs. The Computing Teacher 14(1), p. 13-16.

Kisner, E. (1984, February). "Keyboarding--A Must in Tomorrow's World," The Computing Teacher. 10(5), p. 21-22.

Klelman, G., \& Humphrey, M. (1982). Word Processing In The $\mathrm{Cl}$ assroom. Compute! Issue 22, p. 96-99.

Koening, J. L. (1985). Enchancement of $\mathrm{mlddle}$ school students' written production through the use of word processing. Dlssertation Abstracts International, 45, 2700-2793A. CUnlverslty Mlcrofilms International. 45/9, 2787A)

Kontos, S. (1986, November). What preschool chlldren know about reading and how they learn it. Young Children $42(1), p .58-66$.

Kosecoff Jacqueline \&. Fink Arlene, Evaluation Baslcs: a practitioner's manual, Sage Publications Beverly Hills, 1982

Kurth, R. J., \& Stromberg, L. J. (1984, December). Using word processing in compesition instruction. Paper presented at Annual Meeting of Amerlcan Reading Forum, Sarasota, EL.

Kust, M. J. (1981). Man in the unlverse. Al exandria, VA: Plutarch Press. 
Lake, D. (1985, November/December). Beyond word processing. Classroom Computer Learning. $5(3), p .37-38$.

Leakey, R., \& Lewin, R. (1977), Orlains. New York, NY: E. P. Dutton.

LeCompte Margaret D., Goetz Judith P., "Ethnographlc Data Collection in Evaluation Research," Fetterman David M. edltor, Ethnography In Educatlonal Evaluatlon, Sage, Beverly Hills Callfornla, 1984

Lelchter, H. J. (1984). Families as environments for literacy. In Goelman, H., Oberg, A., \& Smith, F. (Eds.). (1984). Awakening to literacy. Portsmouth, NH: Hel nemann Educational Books.

Leonardl, E. B., \& McDonald, J. L. (1986, Apr 11). Assessing our assumptions. The Computing Teacher, 13(7) p. 47-48.

Levlne, H. (1985, Surmer). Principles of data storage and retrieval for use in qualitatlve evaluations. Educational Evaluation and Policy Analysis. $7(2), 2$. $159-186$.

Levin, J. A., \& Boruta, M. J. (1983, Autumn). Writing with computers in classrooms: You get exactly the rlght amount of space! Theory into Practice. XXII(4), p. 291-295.

Levinson, P. (1983, September). Information technologies as vehicles of evolution. Paper present at the International Conference on Information Technology and Computers, New York, NY.

Lias, E. J. (1982). Euture mind: The microcomputer-- new mediume new mental enviconment. Boston, MA: Little, Brown And Company.

Literacy development and pre-first grade. (1986, May). A joint statement of concerns about present practlces in pre-first grade reading instruction and recommendat lons for improvement. Young chlldren, 41(4), p. 10-13.

Littlefleld, P. (1983, Fall). Word processors in the classroom: Two vlews. Computers. Reading and Lanouage Arts, 1(2), P. 38-39.

Loheyde, K. M. J. (1984, Summer). Computer use in the teaching of composition: Conslderations for teachers of writing. Computers in the Schools, 1(2), p. 81-86. 
Loule, S. (1985, January). Locus of control among computer-using school children. National Advisory Council For Computer Implementation In Schools. Tucson, A2. p.36.

Lowes, R. (1975, July). Do we teach reading in the kindergarten? Young Chlldren. 30(5), p. 328-331.

Lurla, A. R. (1977-1978, Winter). The development of writing in the chlld. Soviet Psychology, 16(2), p. 65-114.

Madian, J. (1986, August/September). Word processing and curriculum renewal. The computing Teacher. $14(1), p$. 17-19.

Mandinach, E. B. \& Iinn, M. C. (1986). The cognitive effects of computer learning environments. Journal of Educational Computing Research. (2) 4, p. 411-427.

Manning, K., \& Sharp, A. (1977). Structuring play in the early years at school. London: Ward Lock Educational.

Marcus, S. (1985). The future of 1 iteracy. In D. Chandler, \& S. Marcus (Eds.), Cemputers and Uteracy. (pp. 108-116). Ph 1 ladelphia, PA: Open University Press.

Marcus, S. (1983, Spr Ing). The muse and the machine: $A$ computers and poetry project. Ripeline, p. 10-12.

Marlen, M. (1983, September-October). Some questlons for the information society. In T. Forester (Ed.), The Intormation Technology Revolution (pp. 648-660). Cambr Idge, MA: The MIT Press.

Marshack, A. (1975, January). Explorling the $\mathrm{mlnd}$ of $\mathrm{lce}$ age man. National Geographle. 147(1), p. 64-89.

Marshall, G. R. (1984 October). Word Processing: Teachlng Approaches. Computers in Education, $p, 22-26$.

Martin, J. H. (1984). Writing To Read. (Teacher's Manual). Boca Raton, FL: International Business Machines Corporation.

Masuda, Y. (1983). Computopia. In T. Forester (Ed.), The Information Technology Revolution (pp. 620-634). Cambridge, MA: The MIT Press.

Mayer, R. E. (1983). Human cognition and the use of new technologles. Paper presented at the Paths to Excellence: Testing and Technology Conference, Los Ange les, CA. 
Mayhar, A. (1984, March). 'Stimulate, don't stifle...', Cult lvating tomorrow's wrlters. NEA Today. 2(5), p. 12.

McCarley, B. (1985 November/December). Why Teach Word Processing To Young Writers? Curriculum Revlew. 25(2), p. $49-50$.

McCroskey, M. (1986, November). Word processors find home in both $c l$ assroom and offlce. THE Technelgaical Horizons In JOURNAL. 14(4), p. 12-14.

McGarvey, J. (1986, March). "Is It Time to Boot Out Cursive Writlng?" Classroom Computer Learning. $5(6)$, p. 36-37.

McKenna, S. (1986, Winter). The Computer Impact on Student Writing. Northwest Council for Computer Education, 5(2), p. 5 .

McKenzie, J. (1984, September). Accordion Writing-Expository Composition with the Word Processor. English Journal. $73(5), p .56-58$.

McLuhan, M. (1962). The Gutenberg galaxy. Toronto, Canada: University of Toronto Press.

MoWl 11 lams, P. A. (1982). The Word Processing Book. Los Angles, CA: Prelude Press.

Mehan, H., Miller-Souviney, B., \& Riel, M. M. (1984, September). Research currents: Knowledge of text editing and control of literacy skllis. Language Arts, 61(5), p. 510-151.

Melmed, A. S. (1986, September). The technology of American education: Problem and opportunity. T.H.F. Technological Hoclzons In Educat lon JOURNAL. 14(2), P. 77-81.

MicroNotes on chlidren \& computers (1984). Clearinghouse on elementary and early chlldhood education. ERIS, 1(5), p. 4.

Miles, M. B., \& Huberman, A. M. (1984). Qualitatlue Data Analygig. Beverly Hills, CA: Sage Publications.

Miller, L., \& Lieberman, A. (1982, February). School leadership between the cracks. Educational Leadership. $39(2), p .362-367$. 
Miller, S. K. (1984). Plugging your pencil into the wall: An investigation of word processing and writing skllis at the middle school level (Doctoral dissertation, University of Oregon, 1984). Dissertation Abstracts International, 45, 3535A.

Milz, V. E. (1980). Flrst graders can wrlte: Focus on communication. Theory Into Practice, XIX(3) p. 179-185.

Moore, S. G., \& Cooper, C. R. (Eds.). (1982). Chapter 1 Personal and sclentific sources of knowledge about children. The Young Chlld review of research, $3, c .1$, National Assoclation for the Education of Young Chlldren, Washlington D.C.

Morell, V. ( 1985 , November-December). WILD lessons. International Whldlife, $15(6)$ p. 46-51.

Morgan, B. A., \& Schwartz, J. M. (Eds.). (1985, February). Setting up a word processing microlab. Research In Word Processing Newsletter, $3(2), p$ 1-2.

Morris, D. (1981, September). Concept of word: A developmental phenomenon in the beginning reading and writing processes. Lanquage Arts, 58(6). p. 659-668.

Morrow, L. M. (1985, May). Reading and retelling stories: Strategles for emergent readers. The Reading Teacher. Зૂ8(8), P. 870-875.

National Commission on Excellence In Education. (1983). A nation at risk. (Stock No. 065-000-00177-20. Washington, DC: U.S. Government Printing Offlce.

NCCE. ( 1980, June). Symposium on effectlve schools. National commlttee for citizens in education. Columbla, MD:

Neve, C. D. (1985, October). Braln-compatible learning succeeds. Educational Leadershlp, 43(8), p. 83-85.

Newman, J. M. (1984, September). Language learning and computers. Lanquage Arts, 51(5), p. 494-497.

Newman, J. M. (1984, November). Online: Reading, writing, and computers. Lanquage Arts, 다 (7), p. 758-763.

Newman, M. (1986, February). Poetry processing. Byte. 11(2), p. 221-228.

Ohanlan, S. (1984, March). Hot new Item or same old stew? Classroom Computer Learning. 4(6), p. 30-33. 
Ohanian, S. (1984, November/December). How today's reading software can zap kids' desire to read. Classroom Computer learning. 5(3), p. 27-31.

Olds, H. F., (1985, March). A new generation of word processors. Classroom Computer Learning. $5(5), p .22-25$.

Ollila, L. O., Collis, B., \& Yore, L. D. (1986, September/October). Predicting first-grade students' wrlting achievement using the Canadian readiness test and selected measures of cognitive development. Journal of Educational Research. $80(1), p .47-52$.

Olson, C. B. (1984, November). Fostering critical thinking skll ls through writing. Educatlonal Leadership. 42(9), p. 28-39.

Olson, D. R. (1985). Introduction. In D. R. Olson, N. Torrance, \& A. Hi ldyard (Eds.), Literacy, language, and learning (pp. 1-15). Cambrldge, Engl and: Cambridge University Press.

Olson, D. R., Torrance, N., \& Hildyard, A. (Eds.). (1985). Literacy, language, and learning. Cambridge, Engl and: Cambrldge Unlversity Press.

Olson, D. R. (1984). "See! Jumping!" Some oral language antecedents of 11 teracy. In H. Goelman, A. Oberg \& F. Smlth (Eds.). (1984). Awakening to literacy. (pp. 185-192). Portsmouth, NH: Helnemann Educational Books.

Oman, P. W., \& Wlllson, D. (1986, September) Paradigm for K-8 computer curriculum deslgn. T.H.E. Technologlcal Hor Izons In Education JOURNAL. 14(2), p. 82-88.

Oxenham, J. (1980). Literacy. London, Engl and: Routledge \& Kegan Paul.

Palmer, A., Dowd, T., \& James, K. (1984 May). Changing Teacher and Student Att 1 tudes Through Word Processing. The Computing Teacher. 10(8), p. 45-47.

Papert, S. (1980) Mindstorms. New York, NY: Baslc Books, Inc., Harper Colophon Books.

Papert, S. (1986, Apr II). The next step: Logowriter. Classreom Computer Learning. S(7), p. 38-40.

Pail, R. (1976, March). Invented spelling in kindergarten. Young Chlidren. $31(3)$, p. 195-200. 
Perl, S. (1983, Fourth Quarter). Reflections on ethnography and writing. The English Record 34(4), p. 10-11. New York State Engl ish Council.

Pfaffenberger, B. (1986, February). A typology of word-processing programs. Research In Word Processing Newsletter, $4(2)$, p. 2-15.

Phenix, J., \& Hannan, E. (1984, December). Word processing in the grade one classroom. Language Arts, $61(8), p$. 804-812.

Piattelli-Palmarini, M., (Ed.). (1980). Lancuage and learning the debate between Jean Piaget and Neam Chomsky. Cambridge, MA: Harvard Unlverslty Press.

Piper, K. I. (1983-84, December/January). The electronic writing machine: Using word processors with students. The Comput ing Teacher. 11(5), p. 82-83.

Plato. (1952). Phaedrus (R. Hackforth, Trans.). New York: The Bobbs-Merrill Company, INC. COrlginal work published approximately 370 B.C.)7

Pollard, R. ( 1983 , Fourth Quarter). Interviewing Strategies for researching composing: A case study. The English Record 34(4), p. 12-14. New York State English Council.

Pollitt, A. H. ( 1984 May). Warming to the Wonders of the Word Processor: An Engl ish Teacher's Introduction to the Computer. The Coomputing Teacher. 10(8), p. 48-49.

Powell, B. (1984, June). Five-year-old authors. Family Computing, p. 58-59.

Radley, G. (1984, March). 'Let creativity bloom,' cultivating tomorrow's writers. NEA Today. $2(5)$, p. 12.

Ralneg, S. C. (1986, March/Apr II). Teacher educator learns from 1st- and 2nd-grade readers and writers. Childheod Education. 62(4), p. 260-264.

Ralph, J. H., \& Fennessey, J. (1983, June). Sclence or reform: Some questlons about the effective schools model. Phi Delta Kappan. 64(10), p. 689-694.

Raslnskl, T. V. (1988, January). The role of interest, purpose, and cholce in early literacy. The Reading Teacher. 41(4). p. 396-400.

Raskin, R. (1985, November). Word processors: New tools for an age-old task. Eamily Computing, p. 44-48. 
Rhodes, L. K. (1981, February). I can read! Predlctable books as resources for reading and writing instruction. The Reading Teacher. 35(5), p. 511-518.

Rlch, S. J. (1985, July). The writing suitcase. Young Children, 40(5), p. 42-44.

Rlchards, M. (1985, February). Word processors... the new centerpiece of language arts. Instructor. XCIV $(\sigma), p$. $82-86$.

Roblinson, B., \& Versluis, E. B. (1985). Electronic test: A choice medlum for reading? In D. Chandler, \& S. Marcus (Eds.), Computers and llteracy. (pp. 26-40). Phil ladelphla, PA: Open UnIversity Press.

Rodrigues, D. (1985, May/June). Using computers in the language arts curriculum. Curriculum Review. 24(5), p. 25-27.

Rosegrant, T. ( 1985 , February). Using the microcomputer as a tool for learning to read and write. Journal of Learning Disabllities. 18(2), p. 113-115.

Rosenbrock, H., et al. (1981). A new industrial revolution? In T. Forester (Ed.), The Information Technology Revolution (pp. 635-647). Cambridge, MA: The MIT Press.

Rutherford, W. L. (1985, September). School princlpals as effective leaders. Phi Delta Kappan. 67(1), p. 31-34.

Sadler, L. V., Greene, W. T., \& Sadler, E. W. \& 1986 , January). Dlagrammat ic writing using word processing: "larger vision" software. Research In Word Processing Newsletter, $4(1)$, p. 2-7.

Sandberg, J. H., \& Pohlman, J. D. (1976, January). Reading on the child's terms. Young Children. 31(2), p. 106-112.

Schachter, F. F., \& Strage, A. A. (1962). Adults' talk and chlldren's language development. Chapter 6 In Moore, $S$. G. \& Cooper, C. R. (Eds.). The Young Child Reviews of Research, 3 C. 6 , Washlington, D.C. Nat lonal Assoclation for the Education of Young Chlldren.

Schantz, L. M. (1983, October). The computer as tutor, tool and tutee in composition. The computing Teacher. 11(3), p. 60-62. 
Schieffelin, B. B. \& Cochran-Sinith, M. (1984). Learning to read culturally: Literacy before schooling. In Goelman, H., Oberg, A., \& Smith, F. (Eds.). (1984). Awakening to literacy (Pp. 3-23). Portsmouth, NH: Heinemann Educational Books.

Schlelfer, N. (1986, November/December). Making the leap to desktop publishing. Classroom Computer Learnlng. I( 3$)$, p. $39-41$.

Schwartz, M. ( 1982 , November). Computers and the Teaching of Writing. Educational Technology. XXII(11), p. 27-29.

Scollon, B. K., \& Scollon, R. (1984). JRUN TRILOGY : Can Tommy read? In Goelman, H., Oberg, A., \& Smith, F. (Eds.). (1984). Awakening to literacy (pp. 131-140). Portsmouth, NH: Heinemann Educational Books.

Serglovann l, T. J. (1984, February). Leadership and excellence in schooling. Educatienal Leadershlp, $41(6)$, p. 4-13.

Shanahan, R. (1988, March). The reading-wrlting relationshlp: Seven instructional principles. The Reading Teacher, $41(7)$, . $636-647$.

Sheingold, K., Kane, J., \& Endreweit, M. (1983, November). Microcomputer use in schools: Developing a research 4agenda. Harvard Educational Review. 5ㅋ̧(4), p. 412-432.

Sherldan, S. (1986, February). Commentary reading acquisition vs. reading learning. The Reading Teacher, $39(6), p$. 500-503.

Shostak, R. (1983, Spring). Computer-assisted composition Instruction: Some promising practices. Pipeline, p. 4-6.

Shuter, R. (1976, Apr 1 1). The promise of particlpant observation research. Journal of Applied Communications Research. $4(1)$, p. 1-7.

Shuy, R. W. (1984, Summer). Language As A Foundation For Education. Theory Inte Practice, XXIII P. 167-174.

Simon, J. (1984). Teaching Writing On A Word Processor: Relatlonship of Self-Management And Locus of Control. Dlssertation 1984, p. 232.

Smith, F. (1983). Egsays inte Literacy. Portsmouth, NH: Hel nemann Educatlonal Books. 
Smith, F. (1984). The creative achievement of 1 iteracy. In Goelman, H., Oberg, A., \& Smith, F. (Eds.). (1984). Awakening to literacy (pp. 143-153). Portsmouth, NH: Heinemann Educational Books.

Smith, J. A., \& Gray, J. M. (1983, November). Learning about reading, writing and fish with the help of a word processor. Australlan Journal of Reading, $6(4), p$. 186-192.

Smith, N. J. (1985, February). The word processing approach to language experience. The Reading Teacher. $37(5)$, . 556-559.

Sorensen, M. R., \& Kerstetter, K. J. (1979, October). Phonetic spelling: A case study. Lanquage Arts, 56(7), p. 798-803.

Southwell, M. G. (1983, Spring). Using computers for developmental writing instruction. Pipeline, p. 13-16.

Spencer, M., \& Baskin, L. (1983). Mlcrocomputers in early childhood education. ERIC, p. 33. Urbana, IL: Clearlnghouse on Elementary and Early Chlldhood Education.

Splliman, C. V., \& Lutz, J. P. (1986, March/April). A writing to read phil osophy. Chlldhood Education. 62 (4), p. 265-268.

Spitzer, M. (1985). Selecting word processing software. In Collins, J. L. \& Sommers, E. A. (Eds.), Writing on-line: Using computers in the teaching of welting (pp. 29-38). Montclalr, NJ: Boynton/Cook Publishers, Inc.

Squire, J. R. (1982). The colllslon of the baslcs movement with current research in writing and language. In $G$. Hil locks, Jr. (Ed.), The Endllsh Curclculum under Fire (pp. 29-37). Urbana, IL: National Councll of Teachers of Engl ish.

Stake Robert, Evaluating educational programs, Organlsation for Economic Co-operation and Development (OECD) Paris France, 1976

Stern, F. (1983). Word processing and beyond. (III.) by James, B., \& Aschwanden, P. Santa Fe, NM: John Muir Publications.

Stubbs, M. (1980). Language and Lteracy. Boston, MA: Routledge \& Kegan Paul. 
Taylor, D. (1982, November). Chlldren's soclal use of print. Reading Teacher. $36(2)$, p. 144-148.

Taylor, D. (1983). Eamily literacy. Portsmouth, Nyi: Hel nemann Educational.

Teal, W. H, Hlebert, E. H., \& Chittenden, E. A. (1987, April). Assessing young children's 1 it teracy development. The Readina Teacher. $40(8)$, p. $772-777$.

Teale, W. H. (1984). Reading to young children: Its slgnlficance for literacy development. In Goelman, H., Oberg, A., \& Smith, F. (Eds.). (1984). Awakening to Literacy (pp. 110-121). Portsmouth, NH: Heinemann Educational Books.

Tech Central. (1986). Transforming Amer lcan education: Reducing the rigk to the nation. A report to the Secretary of Education United States Department of Education. The National Task Force on Educational Technology.

Templeton, S. ( 1980 , January). Young chlldren Invent words: Developing concepts of "word-ness." The Reading Teacher. 333 $(4)$, P. 454-459.

Thompson, R. (1983, Wlnter). Research shows computers promise in language arts. Virginia English Journal, $33(2), p$. 28-31.

Toffler, A. (1980). The Third Wave. New York, NY: Bantam Books.

Toth, M. (1982, Apri1). We write for a reason. Instructor \& Teacher. $X C I(8), p .38-40$.

Tovey, D. R. \& Kerber, J. E. (Eds.). (1986). Roles in literacy learning. Newark, DE: International Readlng Association.

Turner, M. I. (1984). Playlng with computers: the hldden impact of the computer in a school (Doctoral dissertation, Oregon State University, 1984). Dissertation Abstracts Internatlonal, 45, $1291 \mathrm{~A}$.

Vallee, J. (1982). The network revolution: Confessions of a computer scientlst. Berkeley, CA: AndVOr Press, INC.

Vygotsky, I. S. (1978) Mind in soclety. Cole, M., John-Stelner, Scrlbner, S., \& Souberman, E. (Eds.). Cambrldge, MA: Harvard Universlty Press. 
Vygotsky I. S. (1962). Thought and lancuage. Hanfmann E. \& Vakar G. (Eds.). Cambridge, MA: The M.I.T. Press.

Nallace, J. M. (1985, February). Wrlte flrst, then read. Educational Leadershle $42(6), p$. 20-24.

Watt, D. (1983, February). Word processors and writing. Independent Schools, p. 41-43.

Welss, M. J. \& Hagen, R. (1988, February). A key to IIteracy: KIndergartners' awareness of the funtions of print. The Readling Teacher, 41(5), p. 574-578.

Welzenbaum, J. (1985). The myths of artlflclal intelligence. In T. Forester (Ed.), The information technoloay revolution (pp. 84-93). Cambridge, MA: The MIT Press.

Wellman, H. M. (1982). The foundations of knowledge: concept development in the young chlld. In Moore, S. G., \& Cooper, C. R. (Eds.). The Young Child Reviews of Research, 3(c. 7), p. 115-134. Washington, D.C. Hational Association for the Education of Young Children.

Wells, G. (1986). The Meaning Makers. Portsmouth, NH: He i nemann.

Wetzel, K. (1985, June). Keyboarding skills: Elementary, my dear teacher? The Computing Teacher. 12(9), p. 15-19.

Wheeler, F. (1985, March). Can word processing help the writing process? Learning. $13(7), p .54-62$.

Wllcox Kathleen, "Ethnography as a Methodology and Its Applicatlons to the Study of Schooling: A Review", SpIndler George, editor, Delng The Ethnography of Scheoling, Holt, Rlnehart and Winston, New York, 1982 , p. 456-488

Willer, A. (1984, Sumner-Fall). Creatlve writling with computers: What do elementary students have to say? Computers, Reading \& Lancuage Arts, 2(1) p. 39-42.

W1 11 lams, C. K. \& Kamil, C. (1986, November). How do chlldren learn by handling objects? Young Chuldren. $42(1), p$. 23-26.

Wllson, S. (1977, Winter). The use of ethnographlc techniques In educatlonal research. Revlew of Educational Research. $47(1)$, p. 245-265. 
Wolcott, H. F. (1984). Ethnographers sans ethnography: The evaluation compromise. In D. M. Fetterman (Ed.), Ethrography in educational evaluatlon. Beverly Hills, CA: Sage.

Winchester, I. (1985). Altlantans, Centaurlans, and the litron bomb: some personal and social implications of literacy. In D. R. Olson, N. Torrance, \& A. Hildyard (Eds.), Literacy, language, and learning (pp. 34-49). Cambridge, England: Cambridge University Press.

Wood, M. (1982, October). Invented spelling. Lanquage Arts, 59(7). p. 707-717.

Worley, I. (1984, March). Using word processing in composition classes. Paper presented at the Annual Meeting of the Conference on College Composition and communication, p. 10. New York, NY.

Worsley, D. (1985, January-February). Sourdough writing: teaching computer fictlon writing. Teachers \& Writers, $16(3)$, F. $1-6$.

Wresch, W. (1985, August/September). Using logo to teach writing and literary skills. The Computing Teacher. $13(1), 2.24-26$.

Yln, R. K. (1984). Case study research. Beverly HIlls, CA: Sage Publications.

Zinsser, W. (1983). Hrit Ing with a word processor. New York, NY: Harper \& Row, Publlshers. 
APPENDIX A EXAMPLES OF DATA RECORDING INSTRUMENTS 
Monthly Report

Month

Check days children observed:

\section{Children 1 Monday I Tuesday I Wednesdayl Thursdayl Friday I}

\begin{tabular}{lrlllll} 
Week of & & & & & & \\
\cline { 2 - 6 } Alissa & 1 & 1 & 1 & 1 & 1 & 1 \\
\hline Eshell & 1 & 1 & 1 & 1 & 1 & 1 \\
\hline Joel & 1 & 1 & 1 & 1 & 1 & 1 \\
\hline Justin & 1 & 1 & 1 & 1 & 1 & 1 \\
\hline Lauren & 1 & 1 & 1 & 1 & 1 & 1 \\
\hline Rian & 1 & 1 & 1 & 1 & 1 & 1 \\
\hline
\end{tabular}

\begin{tabular}{lrlllll} 
Week of & & & & & & \\
\cline { 2 - 7 } Al issa & 1 & 1 & 1 & 1 & 1 & 1 \\
\hline Eshell & 1 & 1 & 1 & 1 & 1 & 1 \\
\hline Joel & 1 & 1 & 1 & 1 & 1 & 1 \\
\hline Just in & 1 & 1 & 1 & 1 & 1 & 1 \\
\hline Lauren & 1 & 1 & 1 & 1 & 1 & 1 \\
Rian & 1 & 1 & 1 & 1 & 1 & 1
\end{tabular}

Week of

\begin{tabular}{lllllll} 
Al issa & 1 & 1 & 1 & 1 & 1 & 1 \\
\hline Eshell & 1 & 1 & 1 & 1 & 1 & 1 \\
\hline Joel & 1 & 1 & 1 & 1 & 1 & 1 \\
\hline Justin & 1 & 1 & 1 & 1 & 1 & 1 \\
\hline Lauren & 1 & 1 & 1 & 1 & 1 & 1 \\
\hline Rian & 1 & 1 & 1 & 1 & 1 & 1 \\
\hline
\end{tabular}

Week of

\begin{tabular}{lllllll} 
Alissa & 1 & 1 & 1 & 1 & 1 & 1 \\
\hline Eshell & 1 & 1 & 1 & 1 & 1 & 1 \\
\hline Joel & 1 & 1 & 1 & 1 & 1 & 1 \\
\hline Justin & 1 & 1 & 1 & 1 & 1 & 1 \\
\hline Lauren & 1 & 1 & 1 & 1 & 1 & 1 \\
\hline Rian & 1 & 1 & 1 & 1 & 1 & 1 \\
\hline
\end{tabular}

Week of

\begin{tabular}{lllllll} 
Alissa & 1 & 1 & 1 & 1 & 1 & 1 \\
\hline Eshell & 1 & 1 & 1 & 1 & 1 & 1 \\
Jael & 1 & 1 & 1 & 1 & 1 & 1 \\
\hline Justin & 1 & 1 & 1 & 1 & 1 & 1 \\
\hline Lauren & 1 & 1 & 1 & 1 & 1 & 1 \\
Rian & 1 & 1 & 1 & 1 & 1 & 1 \\
\hline
\end{tabular}


Dally Case Study Group Data Collection Week of

Day

Date

\begin{tabular}{ccccccccc}
\hline Subject & WP used & Choice & BT & E T & T T I Activity & I Comments \\
\hline 1 & 1 & 1 & 1 & 1 & 1 & 1 \\
1 & 1 & 1 & 1 & 1 & 1 & 1 \\
1 & 1 & 1 & 1 & 1 & 1 & 1 \\
1 & 1 & 1 & 1 & 1 & 1 & 1 \\
1 & 1 & 1 & 1 & 1 & 1 & 1 \\
1 & 1 & 1 & 1 & 1 & 1 & 1
\end{tabular}

Day

Date

Subiect I WP used Cholce

$\begin{array}{llllllll}1 & 1 & 1 & 1 & 1 & 1 & 1 \\ 1 & 1 & 1 & 1 & 1 & 1 & 1 \\ 1 & 1 & 1 & 1 & 1 & 1 & 1 \\ 1 & 1 & 1 & 1 & 1 & 1 & 1 \\ 1 & 1 & 1 & 1 & 1 & 1 & 1 \\ 1 & 1 & 1 & 1 & 1 & 1 & 1 \\ 1 & 1 & 1 & 1 & 1 & 1 & 1\end{array}$

Day

Date

Subiect I KP used choicel BT I ET I T T I Activitu I Comments

$\begin{array}{lllllll}1 & 1 & 1 & 1 & 1 & 1 & 1 \\ 1 & 1 & 1 & 1 & 1 & 1 & 1 \\ 1 & 1 & 1 & 1 & 1 & 1 & 1 \\ 1 & 1 & 1 & 1 & 1 & 1 & 1 \\ 1 & 1 & 1 & 1 & 1 & 1 & 1 \\ 1 & 1 & 1 & 1 & 1 & 1 & 1 \\ 1 & 1 & 1 & 1 & 1 & 1 & 1\end{array}$

Day

Date

\begin{tabular}{clllllllll} 
Subject & I WP & used & IChoice I & B T & ET & I T T & I Act ivity & I Comments \\
\hline 1 & 1 & 1 & 1 & 1 & 1 & 1 \\
1 & 1 & 1 & 1 & 1 & 1 & 1 \\
1 & 1 & 1 & 1 & 1 & 1 & 1 \\
1 & 1 & 1 & 1 & 1 & 1 & 1 \\
1 & 1 & 1 & 1 & 1 & 1 & 1 \\
1 & 1 & 1 & 1 & 1 & 1 & 1 \\
1 & 1 & 1 & 1 & 1 & 1 & 1
\end{tabular}

Day

Date

Subiect I WP used Choice / BT I ET I T T I Activity I Comments 
Name :

Date:

Time: $B$

E

Daily Case Study Data Coll lection Form

Special Activities: $Y N$

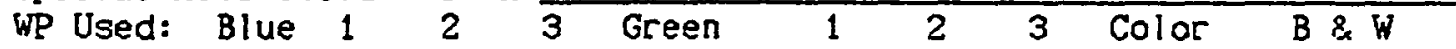

Choice

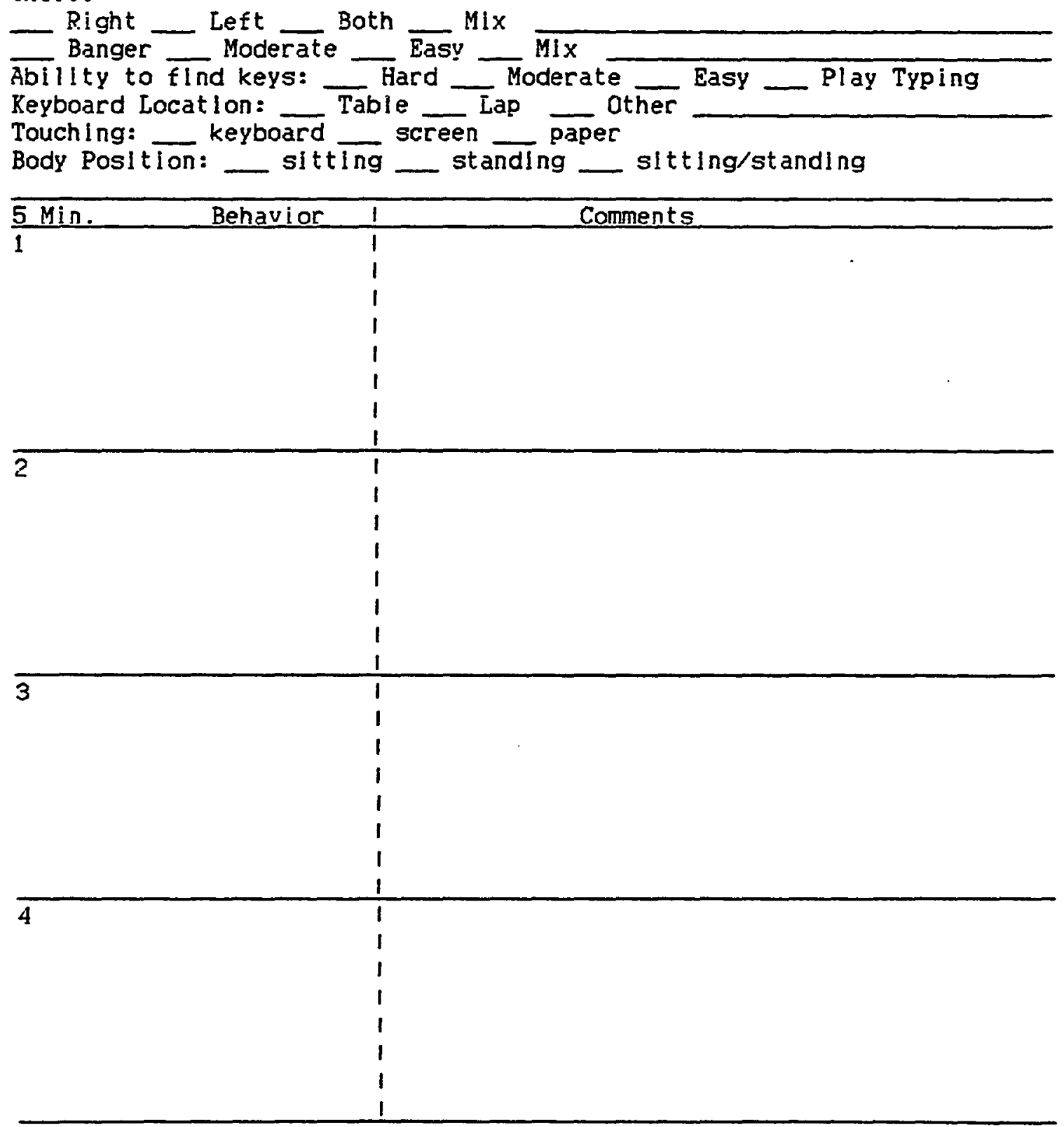




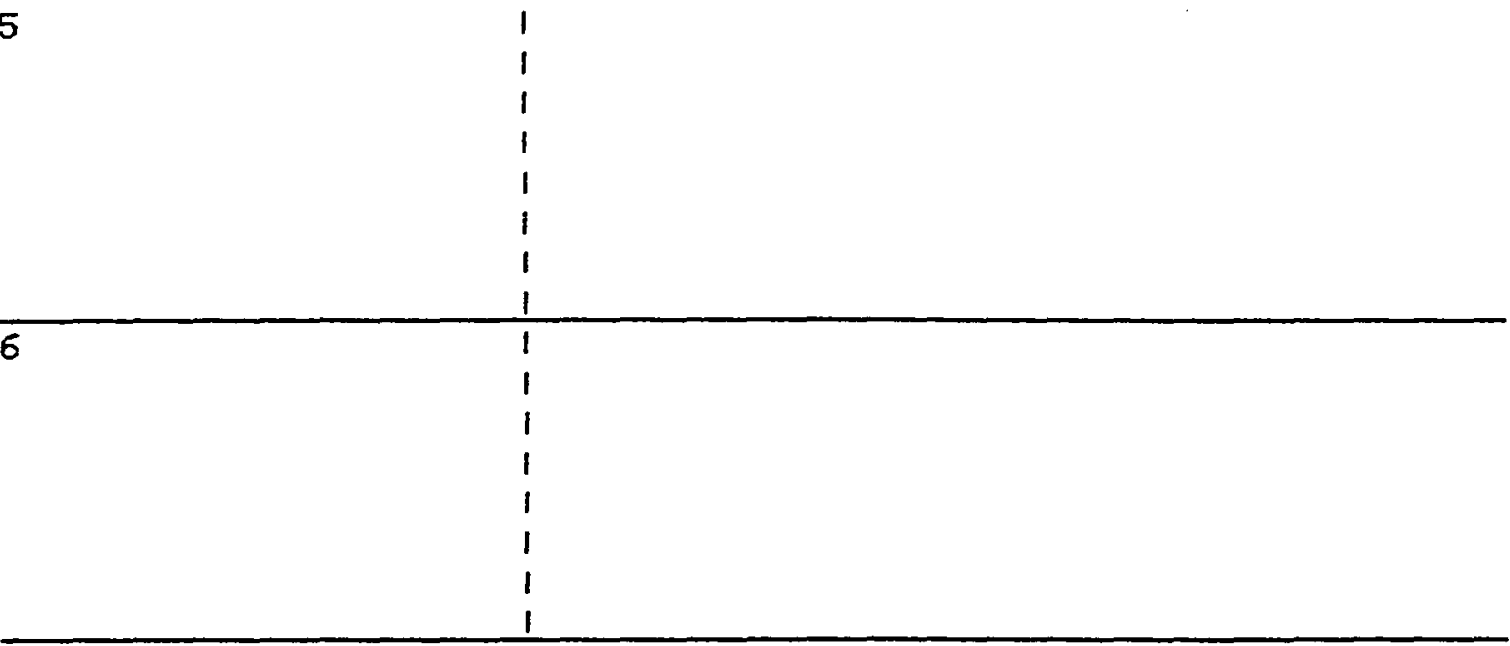

Publishling:

\# of copies Shared with (list)

Printing: by self by peer with peer by adult with adult

Teacher Comments: 
APEENDIX B

EXAMPLES OF DATA ANALYSIS INSTRUMENTS 
Subiect

circle means choice, $x$ means no choice

COMPUTER CHOICE CHART:

Date |Blue IIBlue 2IBIue 3IGreen 1IGreen 2IGreen 31B \& WIColorlCholce

\begin{tabular}{|c|c|c|c|c|c|c|c|c|}
\hline 1 & 1 & 1 & 1 & 1 & 1 & 1 & 1 & 1 \\
\hline 1 & 1 & 1 & 1 & 1 & 1 & 1 & 1 & 1 \\
\hline 1 & 1 & 1 & 1 & $I$ & 1 & 1 & 1 & 1 \\
\hline 1 & 1 & 1 & 1 & 1 & 1 & 1 & 1 & 1 \\
\hline 1 & 1 & 1 & 1 & 1 & 1 & 1 & 1 & 1 \\
\hline 1 & 1 & 1 & 1 & 1 & 1 & 1 & 1 & 1 \\
\hline 1 & 1 & 1 & 1 & 1 & 1 & 1 & 1 & 1 \\
\hline 1 & 1 & 1 & 1 & 1 & 1 & 1 & 1 & 1 \\
\hline 1 & 1 & 1 & 1 & 1 & 1 & 1 & 1 & 1 \\
\hline 1 & 1 & 1 & 1 & $I$ & 1 & 1 & 1 & 1 \\
\hline 1 & 1 & 1 & 1 & 1 & 1 & 1 & 1 & 1 \\
\hline 1 & 1 & 1 & 1 & 1 & 1 & 1 & 1 & 1 \\
\hline 1 & 1 & 1 & 1 & 1 & 1 & 1 & 1 & 1 \\
\hline 1 & 1 & 1 & 1 & 1 & 1 & 1 & 1 & 1 \\
\hline 1 & 1 & 1 & 1 & 1 & 1 & 1 & 1 & 1 \\
\hline 1 & 1 & 1 & 1 & 1 & 1 & 1 & 1 & 1 \\
\hline 1 & 1 & 1 & 1 & 1 & 1 & 1 & 1 & 1 \\
\hline 1 & 1 & $I$ & 1 & 1 & 1 & 1 & 1 & 1 \\
\hline 1 & 1 & 1 & 1 & 1 & 1 & 1 & 1 & 1 \\
\hline 1 & 1 & 1 & 1 & 1 & 1 & 1 & 1 & 1 \\
\hline 1 & 1 & 1 & 1 & 1 & 1 & 1 & 1 & 1 \\
\hline 1 & 1 & 1 & 1 & 1 & 1 & 1 & 1 & 1 \\
\hline 1 & 1 & 1 & 1 & 1 & 1 & 1 & 1 & 1 \\
\hline 1 & 1 & 1 & 1 & 1 & 1 & 1 & 1 & 1 \\
\hline 1 & 1 & 1 & 1 & 1 & 1 & 1 & 1 & 1 \\
\hline 1 & 1 & 1 & 1 & 1 & 1 & 1 & 1 & 1 \\
\hline 1 & 1 & 1 & 1 & 1 & 1 & 1 & 1 & 1 \\
\hline 1 & 1 & 1 & 1 & 1 & 1 & 1 & 1 & 1 \\
\hline 1 & 1 & 1 & 1 & 1 & 1 & 1 & 1 & 1 \\
\hline 1 & 1 & 1 & 1 & 1 & 1 & 1 & 1 & 1 \\
\hline 1 & 1 & 1 & 1 & 1 & 1 & 1 & 1 & 1 \\
\hline 1 & 1 & 1 & 1 & 1 & 1 & 1 & 1 & 1 \\
\hline 1 & 1 & 1 & 1 & 1 & 1 & 1 & 1 & 1 \\
\hline 1 & 1 & 1 & 1 & 1 & 1 & 1 & 1 & 1 \\
\hline 1 & 1 & 1 & 1 & 1 & 1 & 1 & 1 & 1 \\
\hline 1 & 1 & 1 & 1 & 1 & 1 & 1 & 1 & 1 \\
\hline 1 & 1 & 1 & 1 & 1 & 1 & 1 & 1 & 1 \\
\hline 1 & 1 & 1 & 1 & 1 & 1 & 1 & 1 & 1 \\
\hline 1 & 1 & 1 & 1 & 1 & 1 & 1 & 1 & 1 \\
\hline 1 & 1 & 1 & 1 & 1 & 1 & 1 & 1 & 1 \\
\hline 1 & 1 & 1 & 1 & 1 & 1 & 1 & 1 & 1 \\
\hline 1 & 1 & 1 & 1 & 1 & 1 & 1 & 1 & 1 \\
\hline 1 & 1 & 1 & 1 & 1 & 1 & 1 & 1 & 1 \\
\hline
\end{tabular}


Student's Name

Month or $\mathrm{s}$

Li teracy Development Chart

COPY

Write

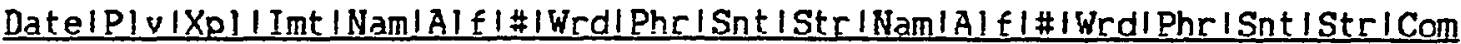

\begin{tabular}{llllllllllllllllll}
1 & 1 & 1 & 1 & 1 & 1 & 1 & 1 & 1 & 1 & 1 & 1 & 1 & 1 & 1 & 1 & 1 & 1 \\
\hline 1 & 1 & 1 & 1 & 1 & 1 & 1 & 1 & 1 & 1 & 1 & 1 & 1 & 1 & 1 & 1 & 1 & 1 \\
\hline 1 & 1 & 1 & 1 & 1 & 1 & 1 & 1 & 1 & 1 & 1 & 1 & 1 & 1 & 1 & 1 & 1 & 1 \\
\hline 1 & 1 & 1 & 1 & 1 & 1 & 1 & 1 & 1 & 1 & 1 & 1 & 1 & 1 & 1 & 1 & 1 & 1 \\
\hline 1 & 1 & 1 & 1 & 1 & 1 & 1 & 1 & 1 & 1 & 1 & 1 & 1 & 1 & 1 & 1 & 1 & 1 \\
\hline 1 & 1 & 1 & 1 & 1 & 1 & 1 & 1 & 1 & 1 & 1 & 1 & 1 & 1 & 1 & 1 & 1 & 1 \\
\hline 1 & 1 & 1 & 1 & 1 & 1 & 1 & 1 & 1 & 1 & 1 & 1 & 1 & 1 & 1 & 1 & 1 & 1 \\
\hline 1 & 1 & 1 & 1 & 1 & 1 & 1 & 1 & 1 & 1 & 1 & 1 & 1 & 1 & 1 & 1 & 1 & 1 \\
\hline 1 & 1 & 1 & 1 & 1 & 1 & 1 & 1 & 1 & 1 & 1 & 1 & 1 & 1 & 1 & 1 & 1 & 1 \\
\hline 1 & 1 & 1 & 1 & 1 & 1 & 1 & 1 & 1 & 1 & 1 & 1 & 1 & 1 & 1 & 1 & 1 & 1 \\
\hline 1 & 1 & 1 & 1 & 1 & 1 & 1 & 1 & 1 & 1 & 1 & 1 & 1 & 1 & 1 & 1 & 1 & 1 \\
\hline 1 & 1 & 1 & 1 & 1 & 1 & 1 & 1 & 1 & 1 & 1 & 1 & 1 & 1 & 1 & 1 & 1 & 1 \\
\hline 1 & 1 & 1 & 1 & 1 & 1 & 1 & 1 & 1 & 1 & 1 & 1 & 1 & 1 & 1 & 1 & 1 & 1 \\
\hline 1 & 1 & 1 & 1 & 1 & 1 & 1 & 1 & 1 & 1 & 1 & 1 & 1 & 1 & 1 & 1 & 1 & 1 \\
\hline 1 & 1 & 1 & 1 & 1 & 1 & 1 & 1 & 1 & 1 & 1 & 1 & 1 & 1 & 1 & 1 & 1 & 1 \\
\hline 1 & 1 & 1 & 1 & 1 & 1 & 1 & 1 & 1 & 1 & 1 & 1 & 1 & 1 & 1 & 1 & 1 & 1 \\
\hline 1 & 1 & 1 & 1 & 1 & 1 & 1 & 1 & 1 & 1 & 1 & 1 & 1 & 1 & 1 & 1 & 1 & 1 \\
\hline 1 & 1 & 1 & 1 & 1 & 1 & 1 & 1 & 1 & 1 & 1 & 1 & 1 & 1 & 1 & 1 & 1 & 1 \\
\hline 1 & 1 & 1 & 1 & 1 & 1 & 1 & 1 & 1 & 1 & 1 & 1 & 1 & 1 & 1 & 1 & 1 & 1 \\
\hline 1 & 1 & 1 & 1 & 1 & 1 & 1 & 1 & 1 & 1 & 1 & 1 & 1 & 1 & 1 & 1 & 1 & 1 \\
\hline 1 & 1 & 1 & 1 & 1 & 1 & 1 & 1 & 1 & 1 & 1 & 1 & 1 & 1 & 1 & 1 & 1 & 1 \\
\hline 1 & 1 & 1 & 1 & 1 & 1 & 1 & 1 & 1 & 1 & 1 & 1 & 1 & 1 & 1 & 1 & 1 & 1 \\
\hline & & & 1 & & COPY & & & 1 & & 1 & 1 & 1 & & 1
\end{tabular}

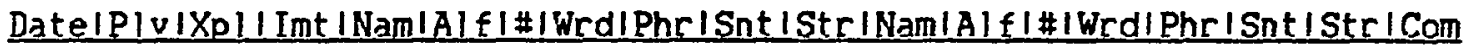

\begin{tabular}{lllllllllllllllllllllllll}
1 & 1 & 1 & 1 & 1 & 1 & 1 & 1 & 1 & 1 & 1 & 1 & 1 & 1 & 1 & 1 & 1 & 1 \\
\hline 1 & 1 & 1 & 1 & 1 & 1 & 1 & 1 & 1 & 1 & 1 & 1 & 1 & 1 & 1 & 1 & 1 & 1 \\
\hline 1 & 1 & 1 & 1 & 1 & 1 & 1 & 1 & 1 & 1 & 1 & 1 & 1 & 1 & 1 & 1 & 1 & 1 \\
\hline 1 & 1 & 1 & 1 & 1 & 1 & 1 & 1 & 1 & 1 & 1 & 1 & 1 & 1 & 1 & 1 & 1 & 1 \\
\hline 1 & 1 & 1 & 1 & 1 & 1 & 1 & 1 & 1 & 1 & 1 & 1 & 1 & 1 & 1 & 1 & 1 & 1 \\
\hline 1 & 1 & 1 & 1 & 1 & 1 & 1 & 1 & 1 & 1 & 1 & 1 & 1 & 1 & 1 & 1 & 1 & 1 \\
\hline 1 & 1 & 1 & 1 & 1 & 1 & 1 & 1 & 1 & 1 & 1 & 1 & 1 & 1 & 1 & 1 & 1 & 1 \\
\hline 1 & 1 & 1 & 1 & 1 & 1 & 1 & 1 & 1 & 1 & 1 & 1 & 1 & 1 & 1 & 1 & 1 & 1 \\
\hline 1 & 1 & 1 & 1 & 1 & 1 & 1 & 1 & 1 & 1 & 1 & 1 & 1 & 1 & 1 & 1 & 1 & 1 \\
\hline 1 & 1 & 1 & 1 & 1 & 1 & 1 & 1 & 1 & 1 & 1 & 1 & 1 & 1 & 1 & 1 & 1 & 1 \\
\hline 1 & 1 & 1 & 1 & 1 & 1 & 1 & 1 & 1 & 1 & 1 & 1 & 1 & 1 & 1 & 1 & 1 & 1 \\
\hline 1 & 1 & 1 & 1 & 1 & 1 & 1 & 1 & 1 & 1 & 1 & 1 & 1 & 1 & 1 & 1 & 1 & 1 \\
\hline 1 & 1 & 1 & 1 & 1 & 1 & 1 & 1 & 1 & 1 & 1 & 1 & 1 & 1 & 1 & 1 & 1 & 1 \\
\hline 1 & 1 & 1 & 1 & 1 & 1 & 1 & 1 & 1 & 1 & 1 & 1 & 1 & 1 & 1 & 1 & 1 & 1 \\
\hline 1 & 1 & 1 & 1 & 1 & 1 & 1 & 1 & 1 & 1 & 1 & 1 & 1 & 1 & 1 & 1 & 1 & 1 \\
\hline 1 & 1 & 1 & 1 & 1 & 1 & 1 & 1 & 1 & 1 & 1 & 1 & 1 & 1 & 1 & 1 & 1 & 1 \\
\hline 1 & 1 & 1 & 1 & 1 & 1 & 1 & 1 & 1 & 1 & 1 & 1 & 1 & 1 & 1 & 1 & 1 & 1 \\
\hline 1 & 1 & 1 & 1 & 1 & 1 & 1 & 1 & 1 & 1 & 1 & 1 & 1 & 1 & 1 & 1 & 1 & 1 \\
\hline 1 & 1 & 1 & 1 & 1 & 1 & 1 & 1 & 1 & 1 & 1 & 1 & 1 & 1 & 1 & 1 & 1 & 1 \\
\hline 1 & 1 & 1 & 1 & 1 & 1 & 1 & 1 & 1 & 1 & 1 & 1 & 1 & 1 & 1 & 1 & 1 & 1 \\
\hline 1 & 1 & 1 & 1 & 1 & 1 & 1 & 1 & 1 & 1 & 1 & 1 & 1 & 1 & 1 & 1 & 1 & 1 \\
\hline 1 & 1 & 1 & 1 & 1 & 1 & 1 & 1 & 1 & 1 & 1 & 1 & 1 & 1 & 1 & 1 & 1 & 1 \\
\hline
\end{tabular}


Name

Month or $s$

Publ lshing Chart

BY

I WITH 1

Datel selflpeer ladult lpeerladult I \# I Shared With

\begin{tabular}{lllllll}
\hline 1 & 1 & 1 & 1 & 1 & 1 & 1 \\
\hline 1 & 1 & 1 & 1 & 1 & 1 & 1 \\
\hline 1 & 1 & 1 & 1 & 1 & 1 & 1 \\
\hline 1 & 1 & 1 & 1 & 1 & 1 & 1 \\
\hline 1 & 1 & 1 & 1 & 1 & 1 & 1 \\
\hline 1 & 1 & 1 & 1 & 1 & 1 & 1 \\
\hline 1 & 1 & 1 & 1 & 1 & 1 & 1 \\
\hline 1 & 1 & 1 & 1 & 1 & 1 & 1 \\
\hline 1 & 1 & 1 & 1 & 1 & 1 & 1 \\
\hline 1 & 1 & 1 & 1 & 1 & 1 & 1 \\
\hline 1 & 1 & 1 & 1 & 1 & 1 & 1 \\
\hline 1 & 1 & 1 & 1 & 1 & 1 & 1 \\
\hline 1 & 1 & 1 & 1 & 1 & 1 & 1 \\
\hline 1 & 1 & 1 & 1 & 1 & 1 & 1 \\
\hline 1 & 1 & 1 & 1 & 1 & 1 & 1 \\
\hline 1 & 1 & 1 & 1 & 1 & 1 & 1 \\
\hline 1 & 1 & 1 & 1 & 1 & 1 & 1 \\
\hline 1 & 1 & 1 & 1 & 1 & 1 & 1 \\
\hline 1 & & $B$ & 1 & WITH & 1 & 1
\end{tabular}

Date Isel f lpeer ladult l peer ladult I \# I Shared with

\begin{tabular}{lllllll}
\hline 1 & 1 & 1 & 1 & 1 & 1 & 1 \\
\hline 1 & 1 & 1 & 1 & 1 & 1 & 1 \\
\hline 1 & 1 & 1 & 1 & 1 & 1 & 1 \\
\hline 1 & 1 & 1 & 1 & 1 & 1 & 1 \\
\hline 1 & 1 & 1 & 1 & 1 & 1 & 1 \\
\hline 1 & 1 & 1 & 1 & 1 & 1 & 1 \\
\hline 1 & 1 & 1 & 1 & 1 & 1 & 1 \\
\hline 1 & 1 & 1 & 1 & 1 & 1 & 1 \\
\hline 1 & 1 & 1 & 1 & 1 & 1 & 1 \\
\hline 1 & 1 & 1 & 1 & 1 & 1 & 1 \\
\hline 1 & 1 & 1 & 1 & 1 & 1 & 1 \\
\hline 1 & 1 & 1 & 1 & 1 & 1 & 1 \\
\hline 1 & 1 & 1 & 1 & 1 & 1 & 1 \\
\hline 1 & 1 & 1 & 1 & 1 & 1 & 1 \\
\hline 1 & 1 & 1 & 1 & 1 & 1 & 1 \\
\hline 1 & 1 & 1 & 1 & 1 & 1 & 1 \\
\hline 1 & 1 & 1 & 1 & 1 & 1 & 1 \\
\hline 1 & 1 & 1 & 1 & 1 & 1 & 1 \\
\hline 1 & 1 & 1 & 1 & 1 & 1 & 1 \\
\hline 1 & 1 & 1 & 1 & 1 & 1 & 1 \\
\hline 1 & 1 & 1 & 1 & 1 & 1 & 1 \\
\hline 1 & 1 & 1 & 1 & 1 & 1 & 1 \\
\hline 1 & 1 & 1 & 1 & 1 & 1 & 1 \\
\hline 1 & 1 & 1 & 1 & 1 & 1 & 1 \\
\hline & 1 & & 1 & & 1 \\
\hline
\end{tabular}


File: Martha Lit Data

Page 1 Report: Analysis

Date Ply Xpl Nam Alph \# Wrd Phrs Snt Stry Nam Alph \# Wrd Phrs Snt Stry -

$\operatorname{Jan} 14$

$\operatorname{Jan} 21$

$\operatorname{Jan} 22 x$

$\operatorname{Jan} 26 x$

$\operatorname{Jan} 27 x$

Feb 10

Eeb 12

Feb 18

Eeb 20

Feb 23

Eeb 24

Feb 28

Mar 3

Mar 4

Mar 10

Mar 16

Mar 18

Mar 10

$\operatorname{Mar} 30$

Apr 2

Apr 8

Apr $10 \quad y$

Apr 16

Apr 21

Apr 28

Apr 28

$x$ cdt

$x$

$x \quad x$

$x$

$\mathrm{x}$

$\mathrm{x}$

$x$

$x$

$\mathrm{x}$

$\mathrm{x}$

$x \quad x$

$x$

$\mathrm{x} \quad \mathrm{x}$

Apr 28

Apr 29

Apr 30

May $6 x$

May 12

May 18

May 19

Mav 21

May 26

May 27

Jun 2

$x$

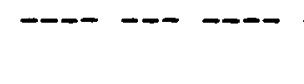

$x$

$$
x
$$
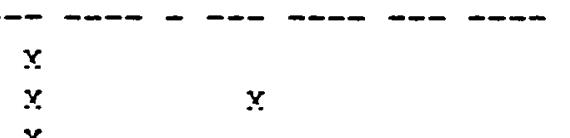

$x \quad x$

$x \quad x$

$x \quad x$

$x \quad x$

$x \quad x \quad x$

$y \quad x \quad x \quad x$

$x \quad y$

$x \quad y \quad x$

$x \quad x \times x$

$x \quad x$

$x$
$x$

$x \quad x$

$x \quad y \quad x$

$x \quad x \quad x$

$x$

$\mathbf{x}$

$x$

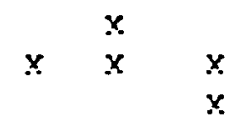

$x$

$x$

$x$

$x$

$x$

$x$

$x$ 
File: Christy Lit Data

Page 1

Report: Analysis

Date Ply Xpl Nam Alph \# Wrd Phrs Snt Stry Nam Alph \# Wrd Phrs Snt Stry

Jan 12 Nan

Jan $20 \quad x$

Jan 22

$\operatorname{Jan} 26 \times x$

Jan 27

Feb 10

Feb 13

Feb $18 x$

Feb $20 x$

Feb 26

Mar 10

Mar 11

Mar 12

Mar 16

Mar 17

Mar $18 x$

Mar 30

Mar 31

Mar 31

Apr $7 x$

Apr $17 x$

Apr $21 \quad x$

Apr 2?

Apr 30

$x$

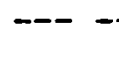

May 1

May 5

May $1^{\circ}$

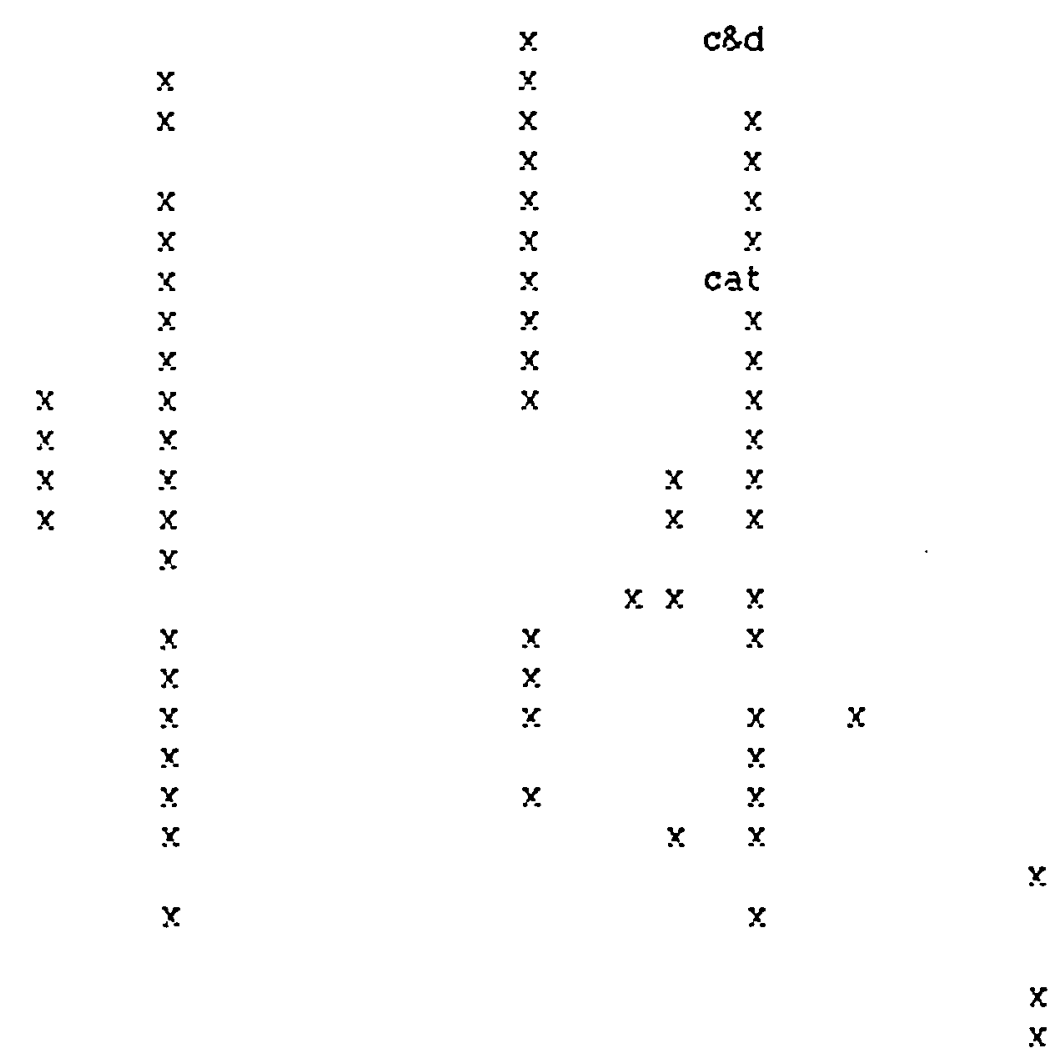


File: Dave Lit Data

Page 1

Report: Analysis

Date Ply Xpl Nam Alph \# Wrd Phrs Snt Stry Nam Alph \# Wrd Phrs Snt Stry

\begin{tabular}{|c|c|c|c|c|c|c|c|c|c|c|}
\hline $\operatorname{Jan}$ & 13 & & $x$ & cat & $x$ & & & & & \\
\hline $\operatorname{Jan}$ & 14 & & & cat & $x$ & & $x$ & & & \\
\hline $\operatorname{Jan}$ & 20 & $x$ & & & $x$ & & $x$ & & & \\
\hline ian & 21 & & $x$ & & $x$ & & $x$ & & & \\
\hline Jan & 22 & $x$ & & & $x$ & & $x$ & & & \\
\hline Jan & 27 & $x$ & $x$ & & $x$ & $x$ & $x$ & & & \\
\hline Jan & 29 & $x$ & & $x$ & $x$ & $x$ & $x$ & & & \\
\hline Feb & 4 & $x$ & $x$ & $x$ & $x$ & $x$ & $x$ & & & \\
\hline Feb & 11 & & & $x$ & $x$ & & $x$ & & & \\
\hline Feb & 17 & & & $x$ & $x$ & & $x$ & & & \\
\hline Eeb & 17 & & & $x$ & $x$ & & $x$ & & & \\
\hline Feb & 23 & & & $x$ & & & $x$ & & & \\
\hline Feb & 26 & & & & $x$ & & $x$ & & & \\
\hline Mar & 3 & & & $x$ & $x$ & & $x$ & & & \\
\hline Mar & 11 & & & & & & & $x$ & $x$ & $x$ \\
\hline Mar & 17 & $x$ & $x$ & $x$ & & & $x$ & & & \\
\hline Mar & 19 & $x$ & $x$ & $x$ & & & $\mathbf{Y}$ & & & \\
\hline Mar & 31 & & & $x$ & & & $\mathrm{x}$ & & & \\
\hline Apr & 1 & $x$ & $x$ & $x$ & & & $x$ & & & \\
\hline Apr & 2 & & & & & & & & & $x$ \\
\hline Apr & 8 & & & & & & & & & $x$ \\
\hline Apr & 22 & & & & & & & & & $x$ \\
\hline Apr & 23 & & & & & & & & & $x$ \\
\hline Apr & $2^{\circ}$ & & & & & & & & & $x$ \\
\hline May & 5 & & & $x$ & & & $x$ & & & \\
\hline May & 6 & & $\boldsymbol{x}$ & $x$ & & & & & & \\
\hline May & 7 & $x$ & & $x$ & & & $x$ & $x$ & & \\
\hline May & 11 & $\boldsymbol{Y}$ & $x$ & & & & & & & \\
\hline May & 12 & $x$ & & & & $x$ & $x$ & & & \\
\hline May & 13 & $x$ & & & & & $\mathbf{x}$ & & & \\
\hline May & 19 & $x$ & $x$ & & & & & & & \\
\hline May & 21 & $x$ & $\mathbf{Y}$ & & & & & & & \\
\hline May & 22 & $x$ & $x$ & & & & & & & \\
\hline ay & 27 & $x$ & $x$ & $x$ & & $x x$ & $x$ & $x$ & & \\
\hline
\end{tabular}


File: Rachel Lit Data

Page 1

Report: Analysis

Date Ply Xpl Nam Alph \# Wrd Phrs Snt Stry Nam Alph \# Wrd Phrs Snt Stry

--c--- -- --- --- -.-- -

$\operatorname{Jan} 14$

Jan 21

Feb 2

Feb 3

Feb 9

Feb 12

Feb 18

Feb 19

Feb 26

Mar 3

Mar 4

Mar 12

Mar 17

Mar 10

Mar 30

Apr 1

Apr 6

Apr 16

Apr 27

Apr 30

May 12

Maỵ 22

Jun 2

\section{cat}

$x$

$x$

$x$

$\mathrm{x}$

$x$

$\mathrm{x}$

$\mathrm{x}$

$\mathbf{x}$

$\mathbf{x}$

$\mathrm{x}$

$x$

$y$

$\mathrm{x}$

$\mathrm{x}$

$x$

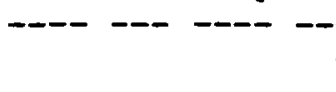

$x \quad x$

$x \quad y$

$x$

$x \quad x$

$x \quad x$

$x \quad x$

$x \quad x$

$x \quad y$

$x \quad x$

$x \quad x$

$x \quad x$

$x \quad x$

$\times$

$x \quad x$

$x$

$x$
$x$

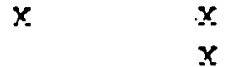

$\mathbf{x}$
$\times \quad$
$\mathbf{x}$
$\mathbf{x}$

$x$ 
File: Mark Lit Data

Page 1

Report: Analysis

Date Ply Xpl Nam Alph \# Wrd Phrs Snt Stry Nam Alph \# Wrd Phrs Snt Stry

$\operatorname{Jan} 12 x$ x $x$ cat $x$

$\operatorname{Jan} 22 x$

Jan 26

Jan 27

Eeb 2

Feb $3 x x$

Feb 9 x

Feb 11

Feb 17

Feb 26

Mar 11

Mar 12

Mar $10 x$

Mar 30

$x$

$\mathrm{x}$

$x$

Apr 10

Apr $16 x$

Apr 20

May $4 x$

May 14

May 18

May 26

$x+x$

$\mathrm{x}$
$\mathrm{x}$
$\mathrm{x}$
$\mathrm{x}$
$\mathrm{x}$
$\mathrm{x}$
$\mathrm{x}$
$\mathrm{x}$

\section{$x$}

$\begin{array}{ll}x & x \\ x & x\end{array}$

$x \quad x$

$x \quad y$

$x \quad x$

$x$

$x \quad x$

$x$

$x$

$\mathbf{x}$

$\mathbf{x}$

$x$

$x$

$x$
$x$
$x$
$x$

$x$ 
APPENDIX D

SUBJECTS' INDIVIDUAL QUALITATIVE COLLAPSED DATA 


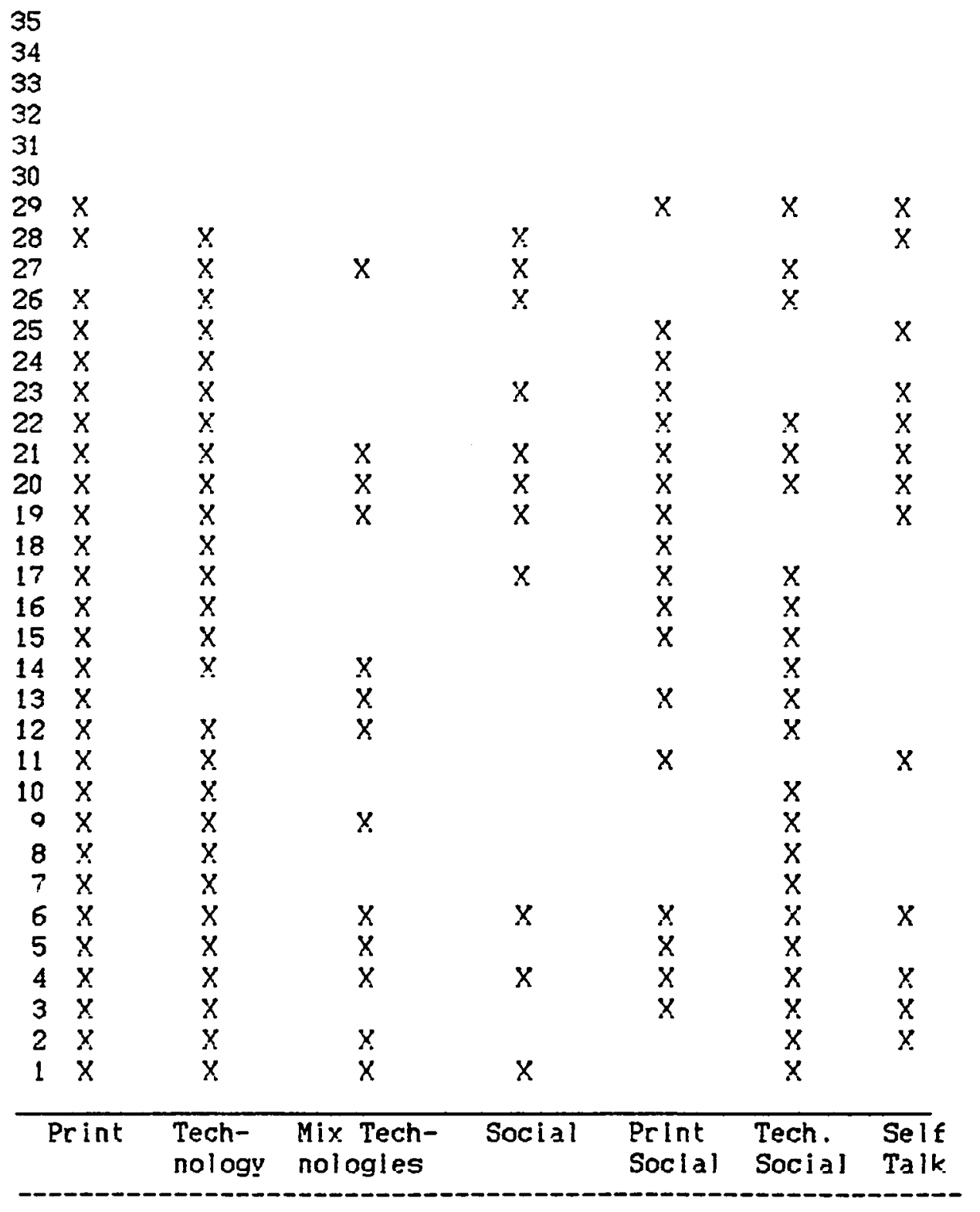

Martha's frequency of print and technologlcal literacy associated behaviors with each opportunity to use a word processor. 


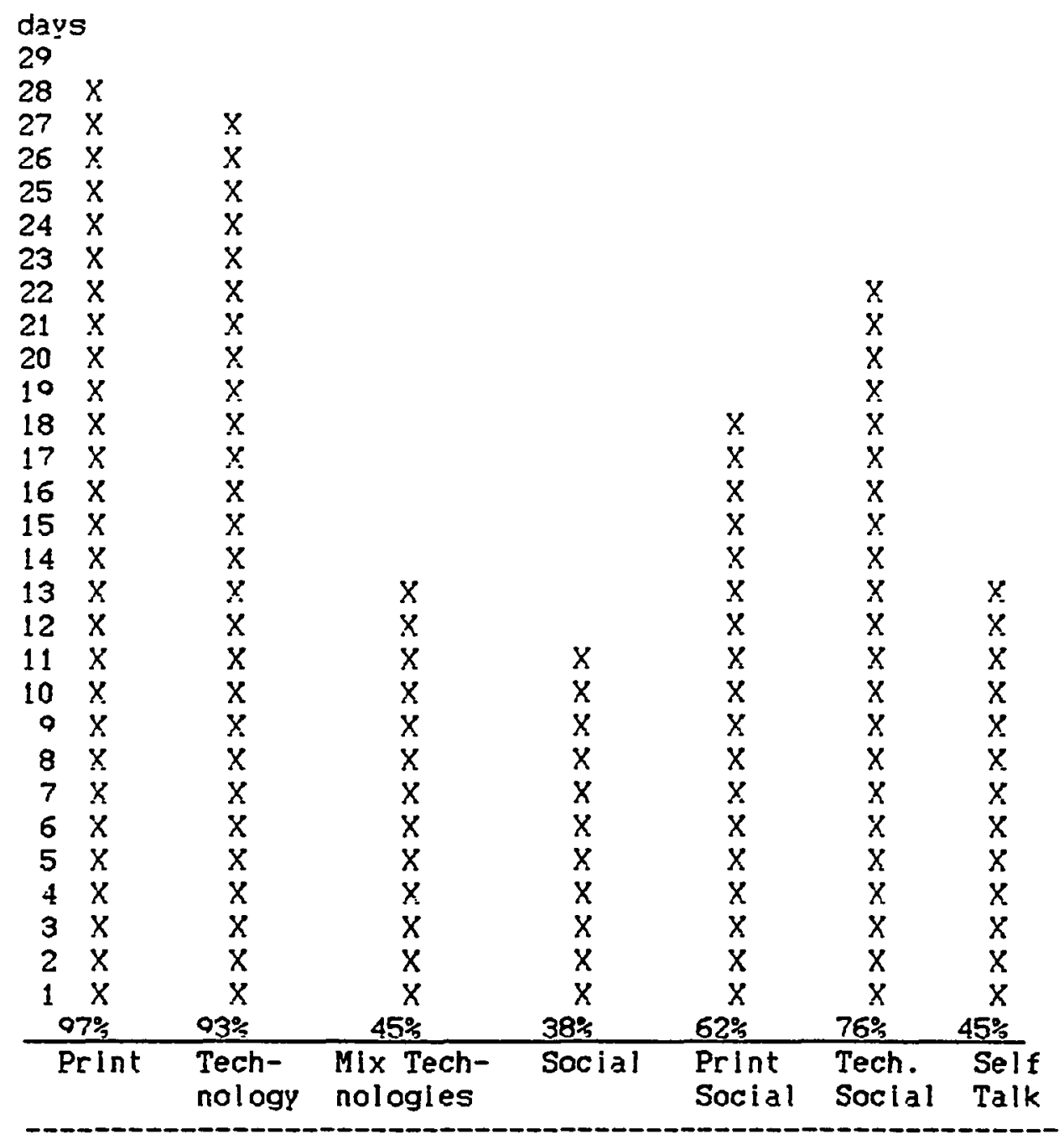

Frequencles and percentages of Martha's print and technologlcal literacy behaviors with each opportunity to use a word processor. $N=20$ 


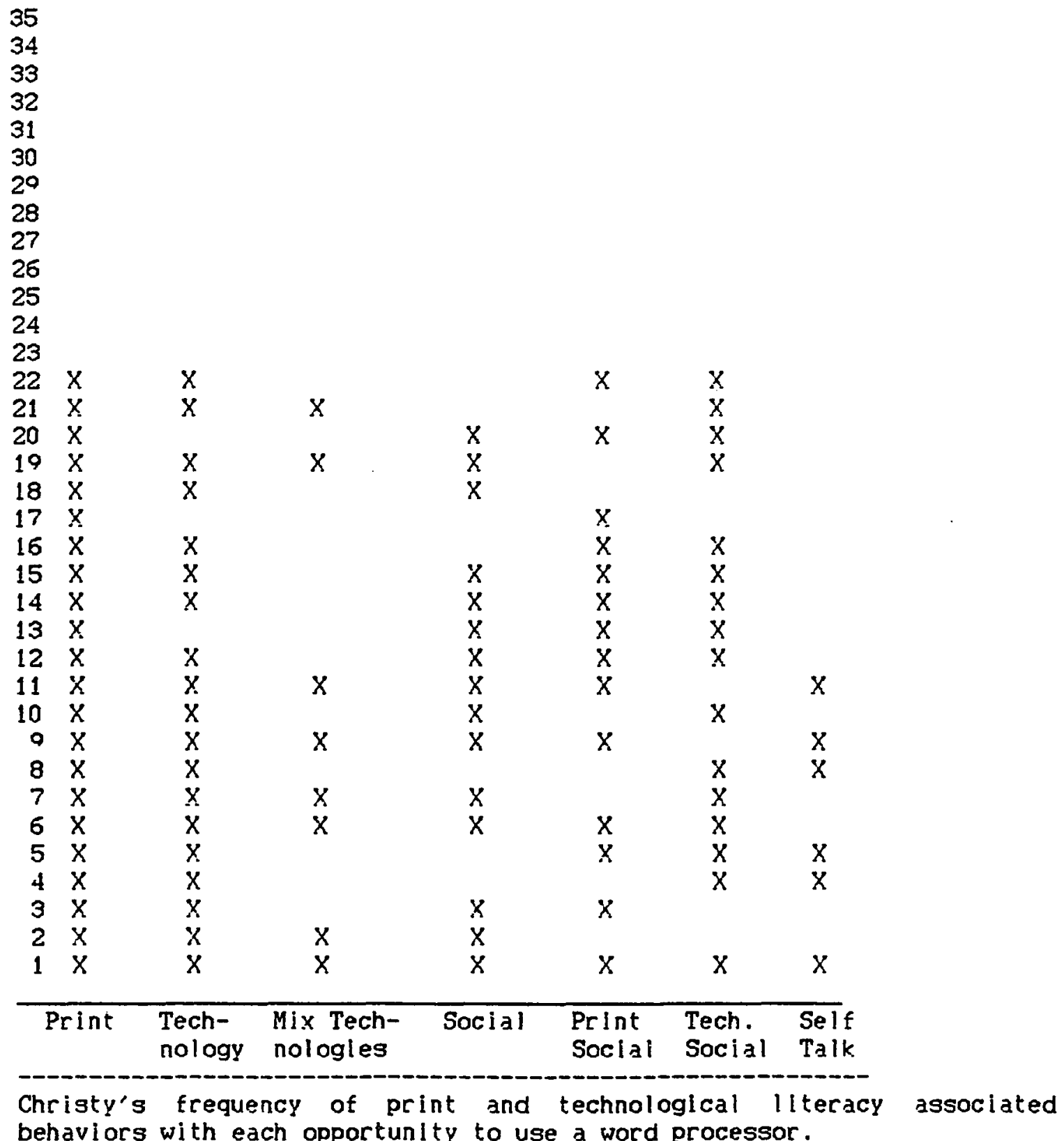




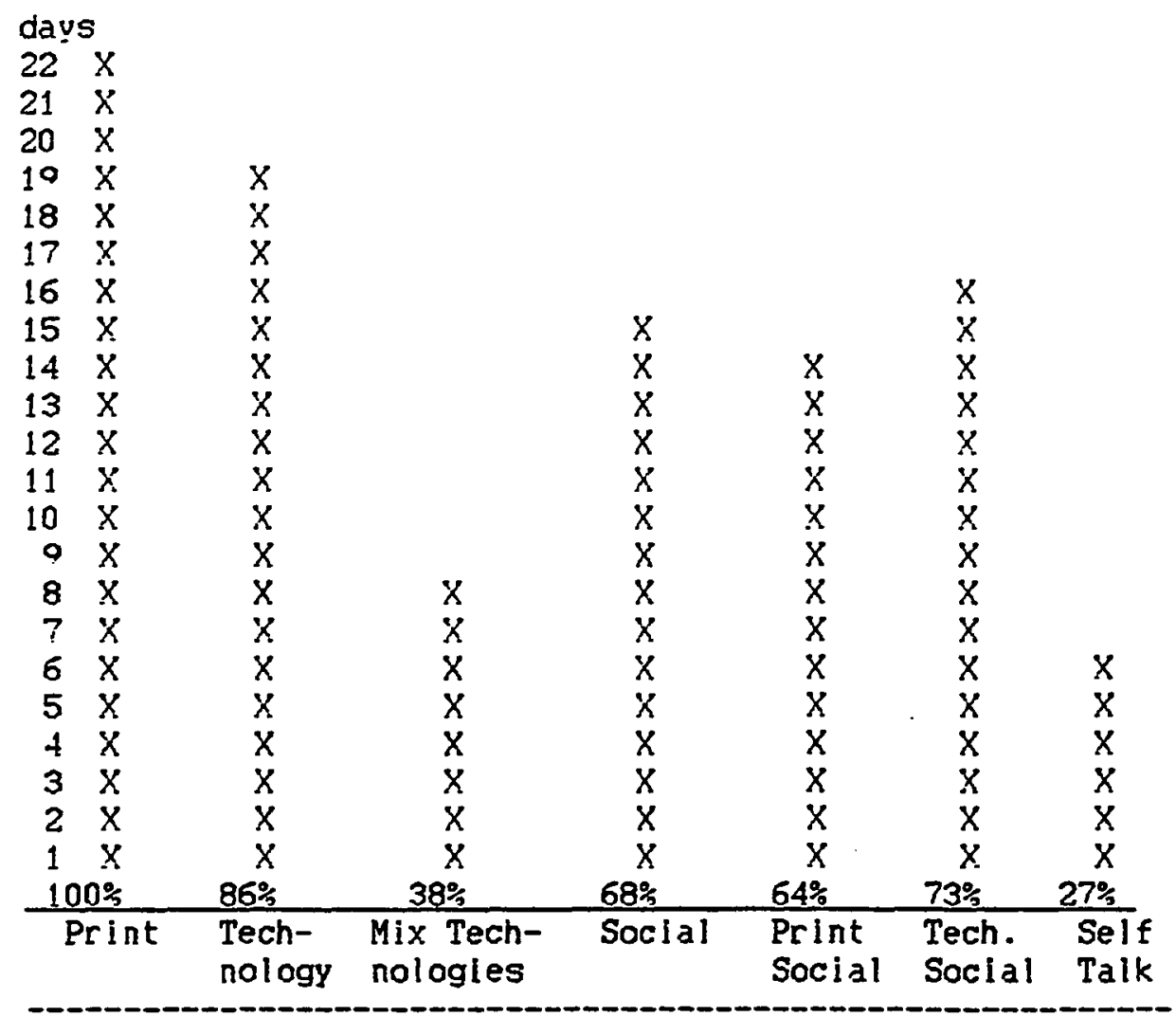

Frequencies and percentages of Christy's print and technological literacy behaviors with each opportunlty to use a word processor. $N=22$ 


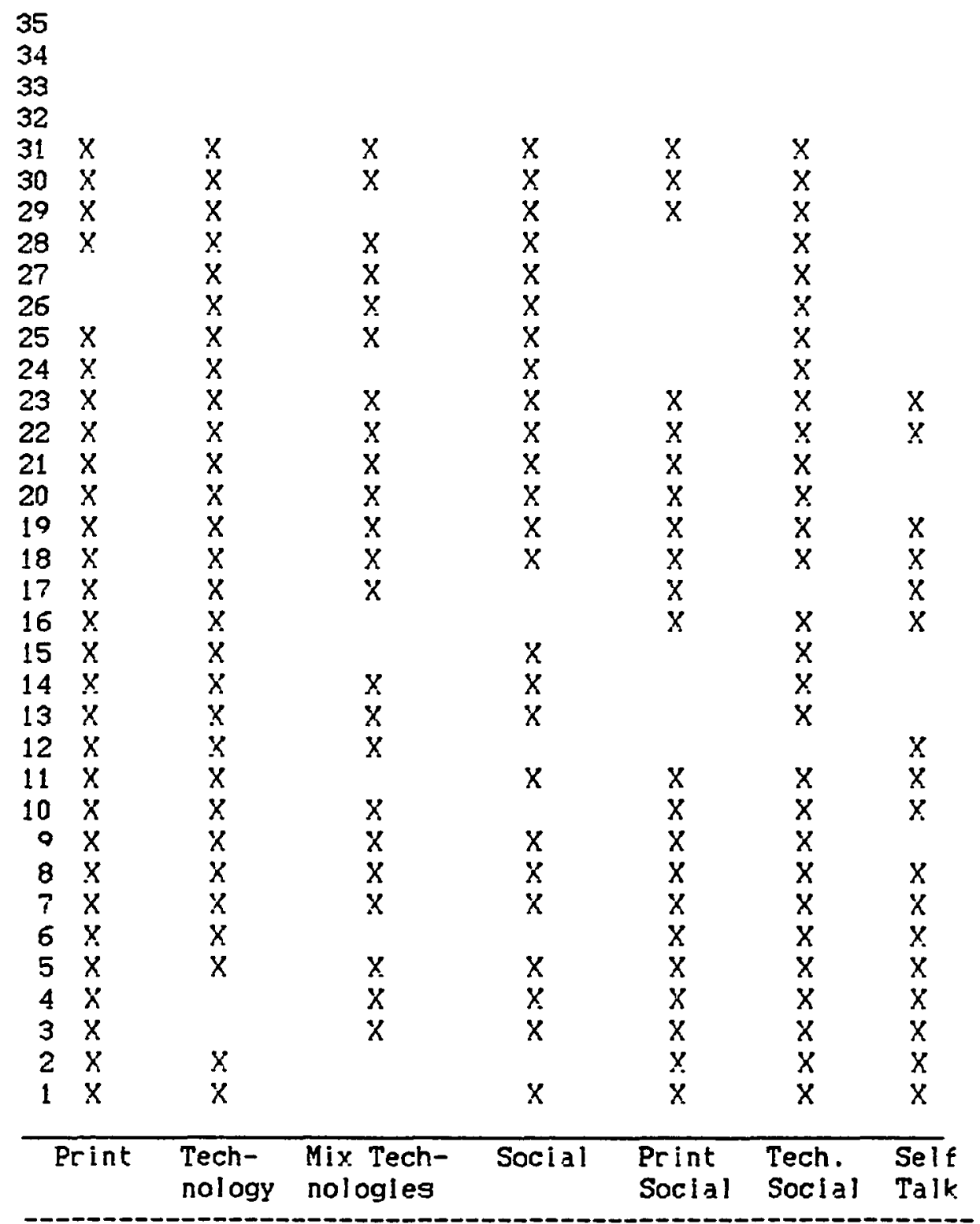

Dave's frequency of print and technological llteracy associated behaviors with each opportunity to use a word processor. Dave 


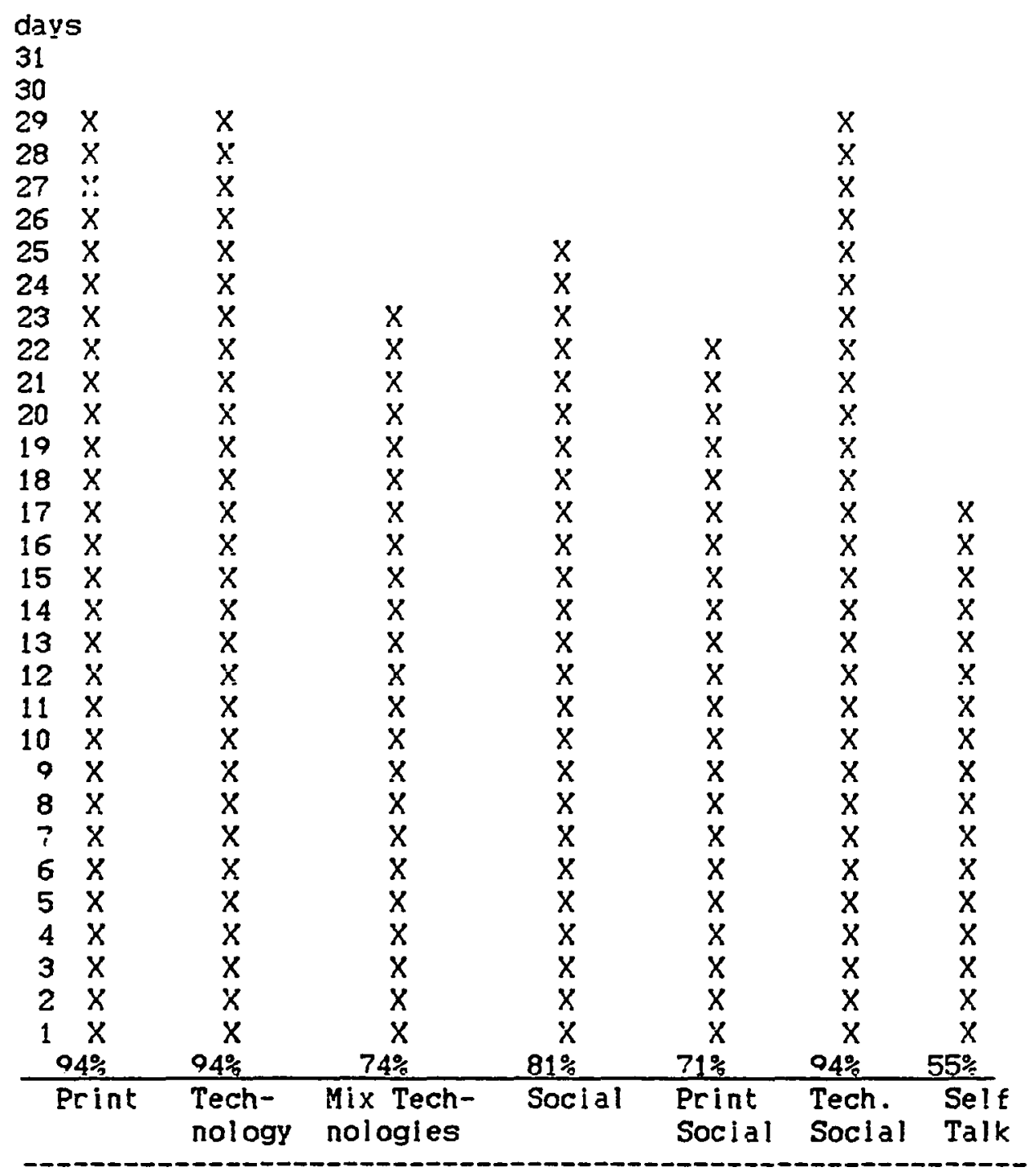

Frequencies and percentages of Dave's print and technological IIteracy behaviors with each opportunity to use a word processor. $N=31$ 


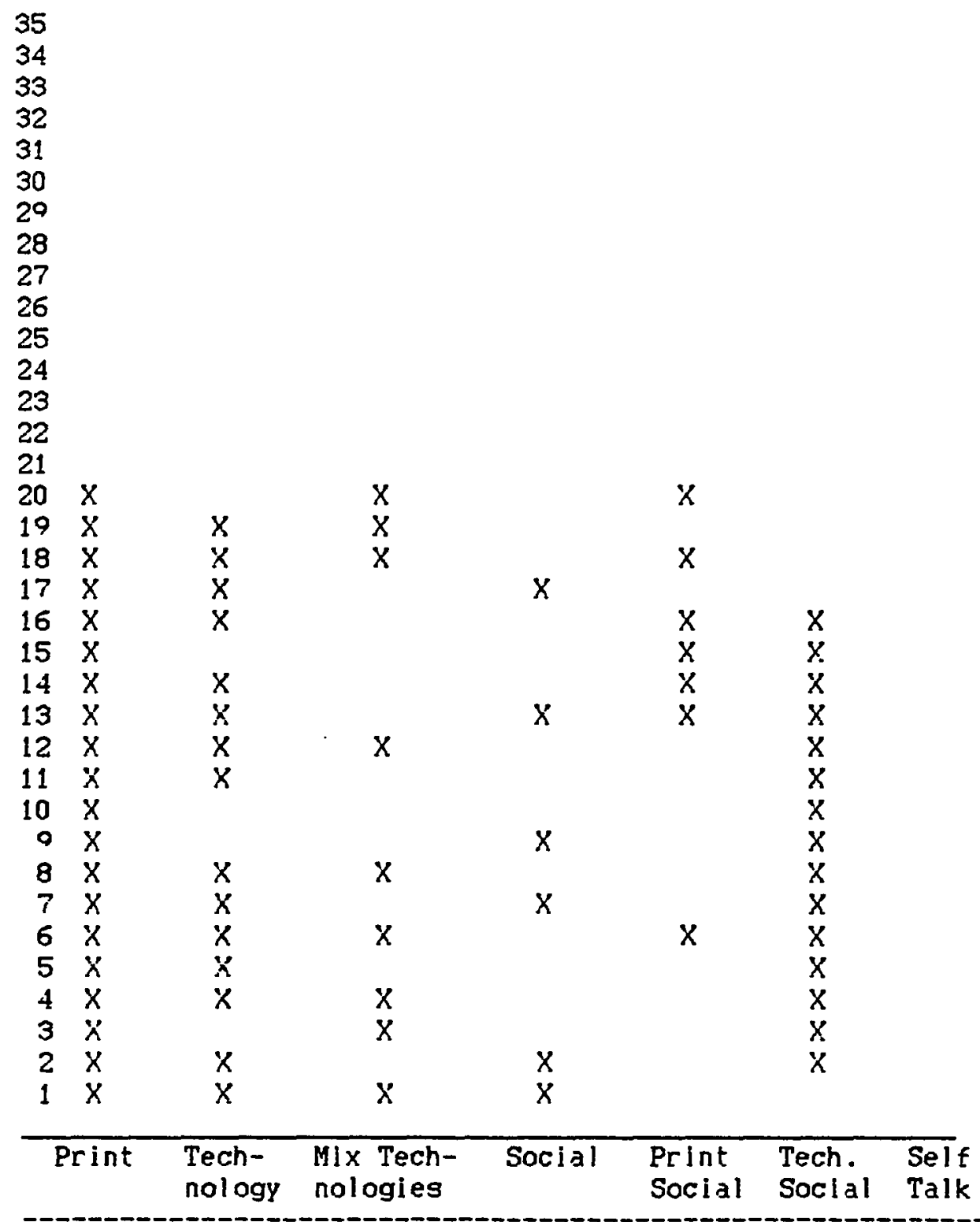

Rachel's frequency of print and technological literacy associated behaviors with each opportunity to use a word processor. 


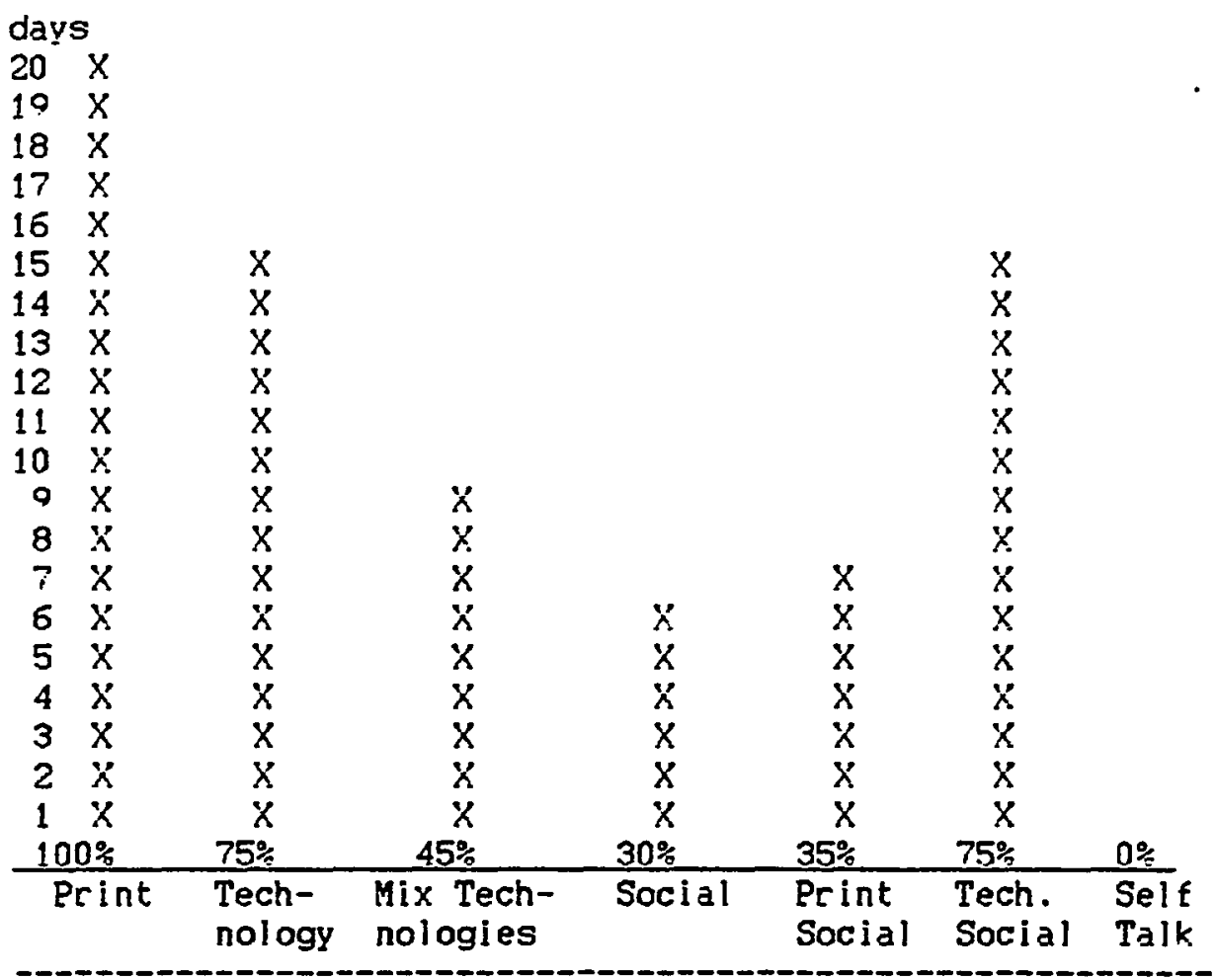

Frequencies and percentages of Rachel's print and technological literacy behaviors with each opportunlty to use a word processor. $N=20$ 


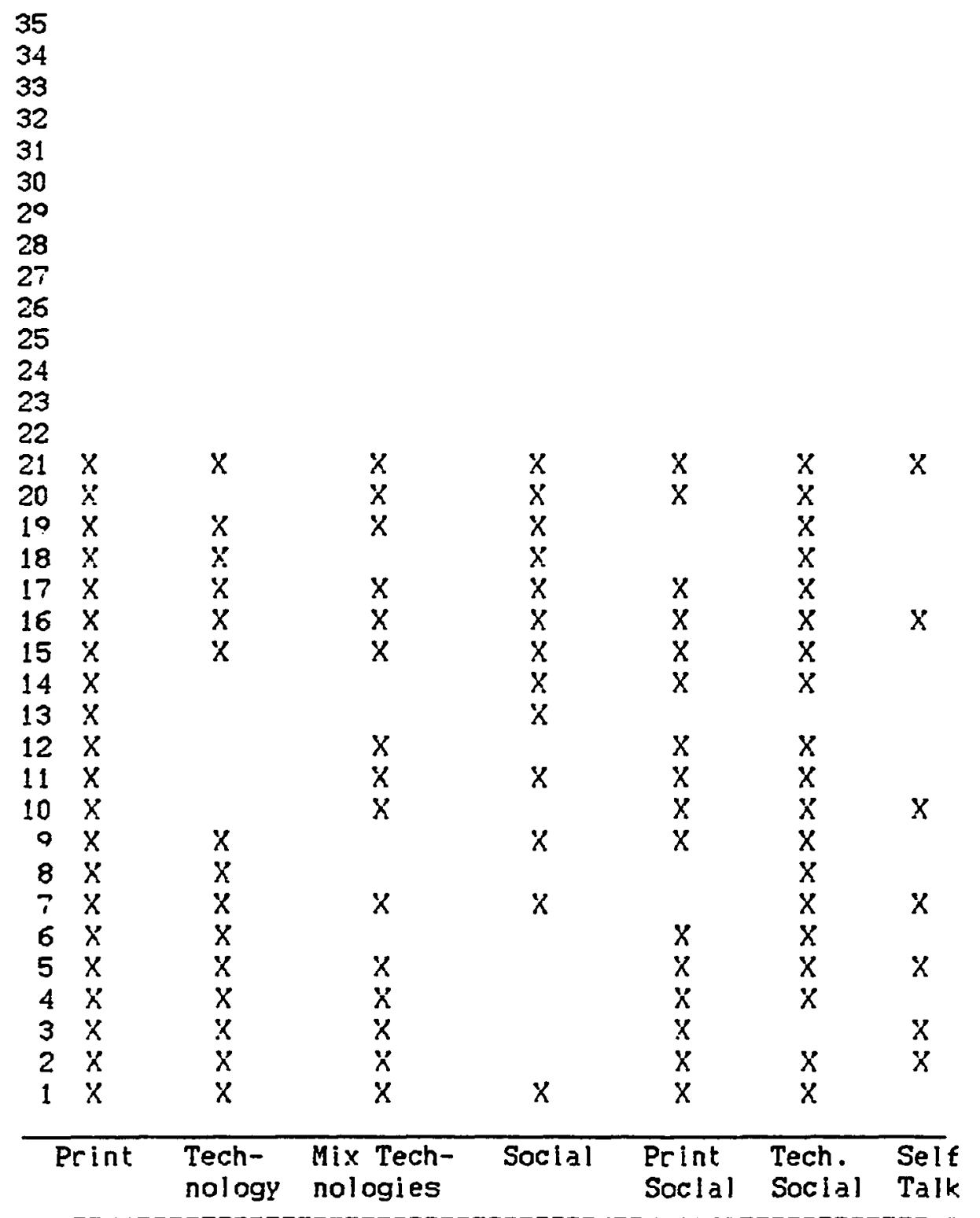

Mark's frequency of print and technological IIteracy associated behaviors with each opportunlty to use a word processor. 


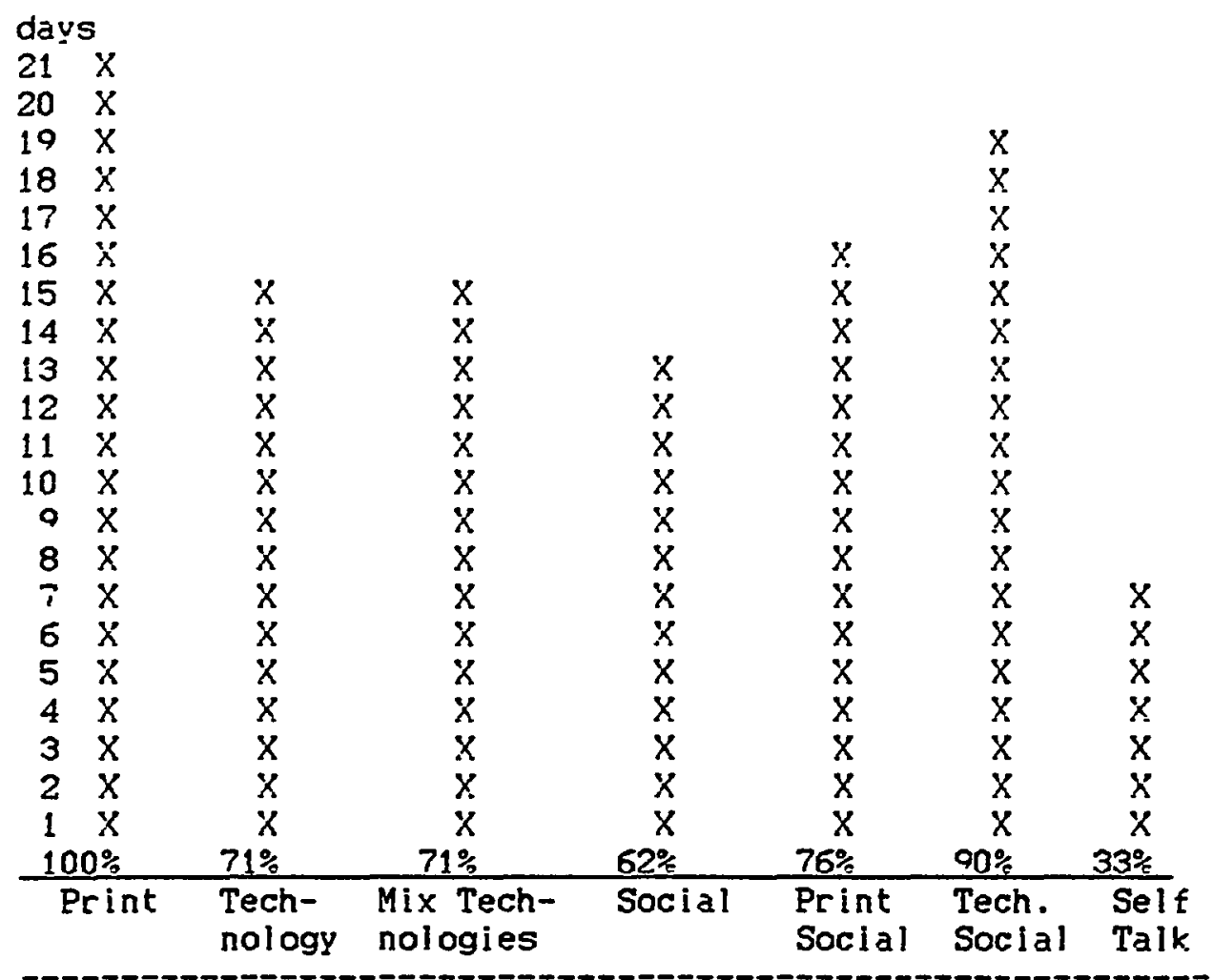

Frequencies and percentages of Mark's print and technological literacy behaviors with each opportunity to use a word processor. $N=21$ 
APEENDIX E

SUBJECTS' TIME ANALYSIS SPREAD SHEETS 
File: Subject Time

Subject's Time On Task

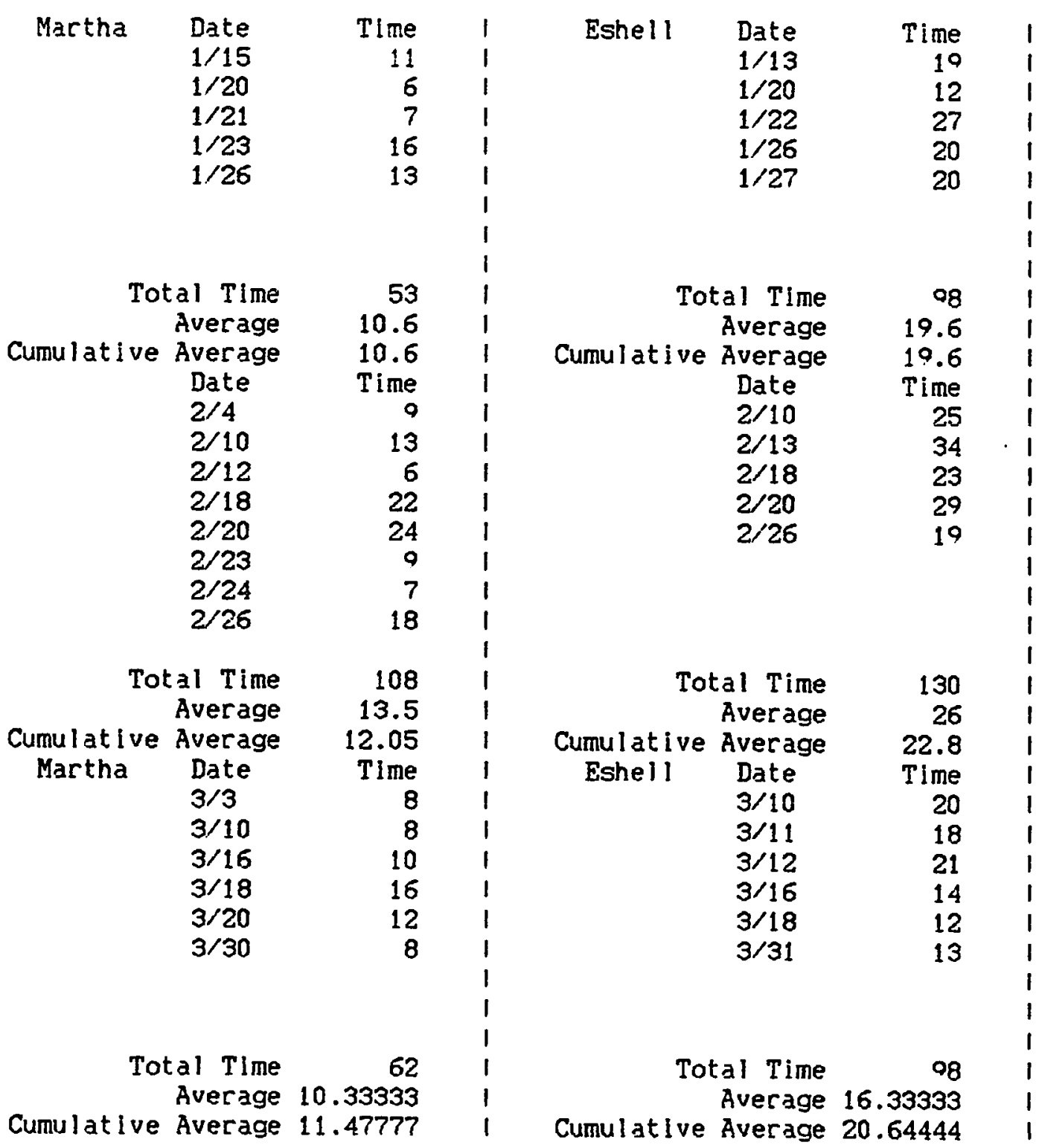




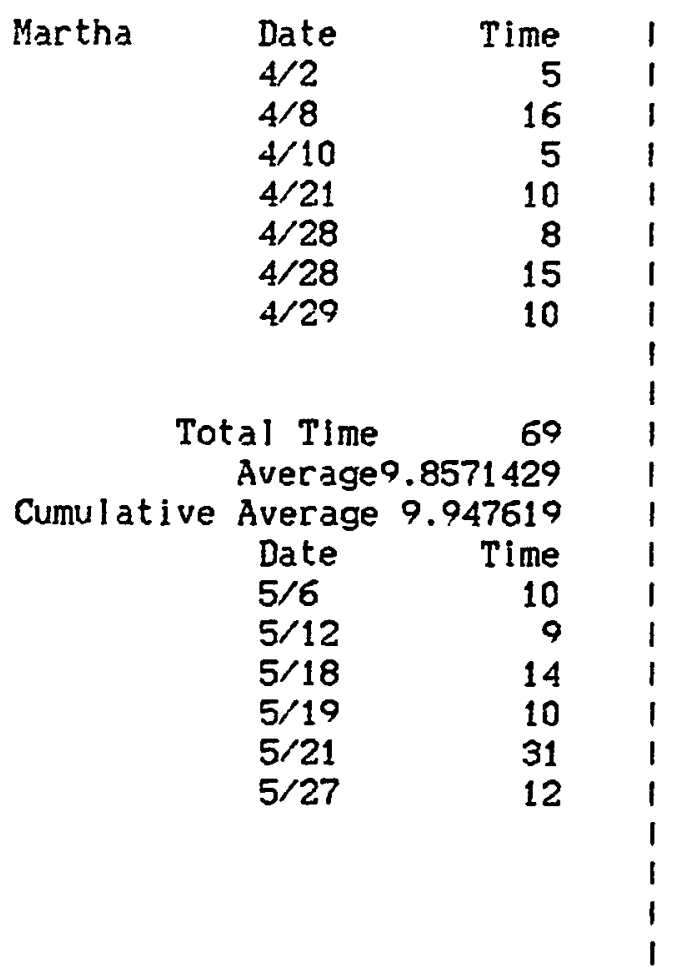

$$
\begin{array}{cl}
\text { Christy } & \text { Date } \\
& 4 / 7 \\
& 4 / 13 \\
4 / 17 \\
4 / 21 \\
4 / 27 \\
4 / 29
\end{array}
$$

Time

Total Time

13.66665

Cumulative Average Date

$5 / 1$

$5 / 5$

$5 / 19$

18.65

Time

10

13

Flle: Subject Time

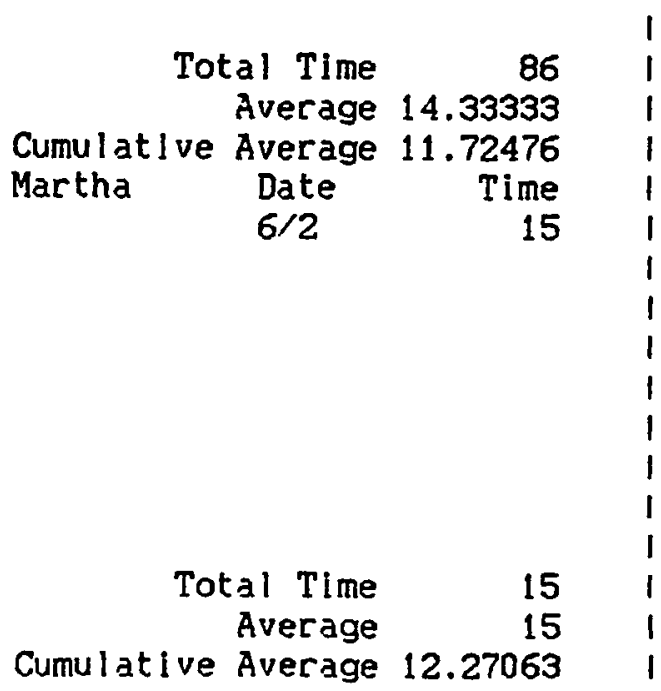

Study's Total Time 393

Total Time in Hour $\quad 6.55$

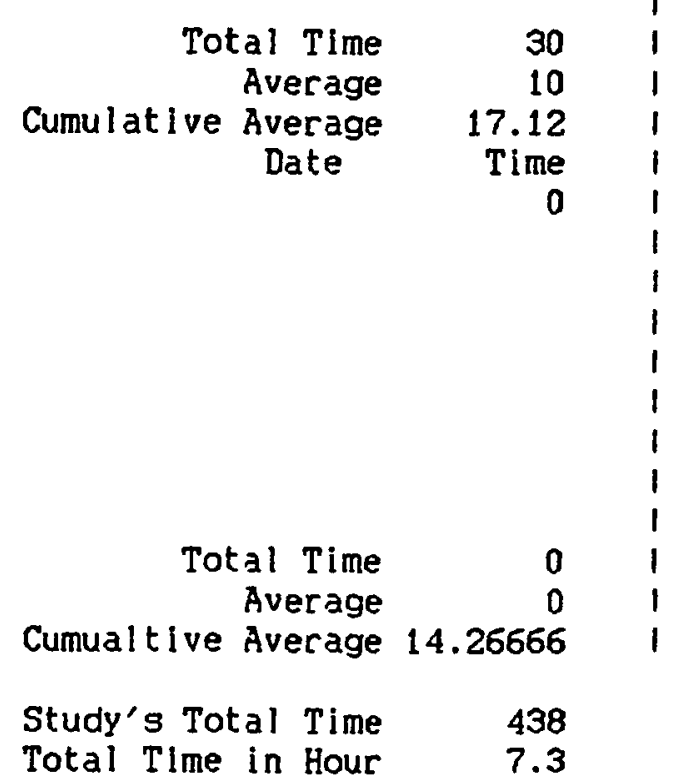

Total minutes of study related observation time 
File: Subject Time

Page 1

Subject's Time On Task

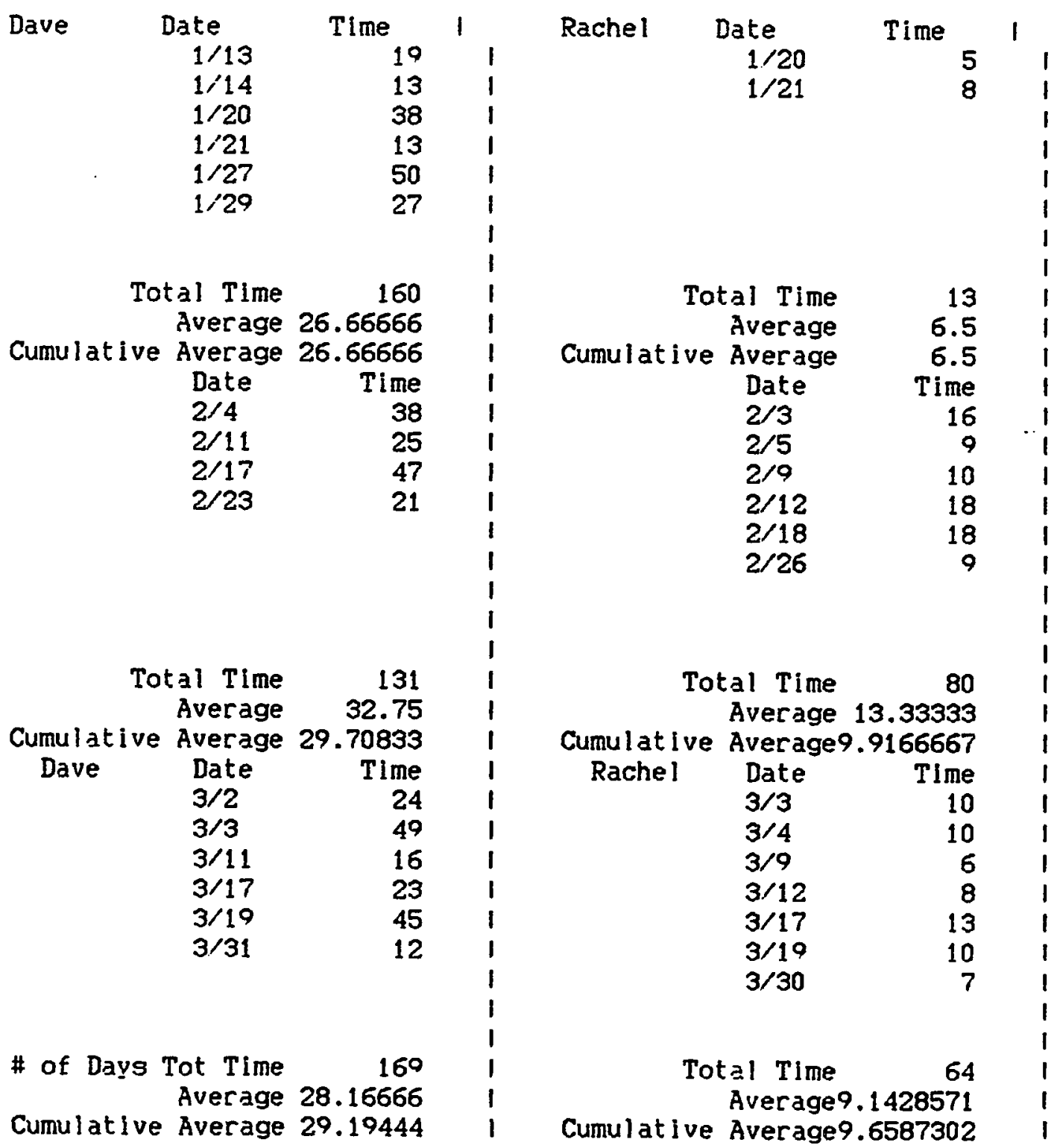




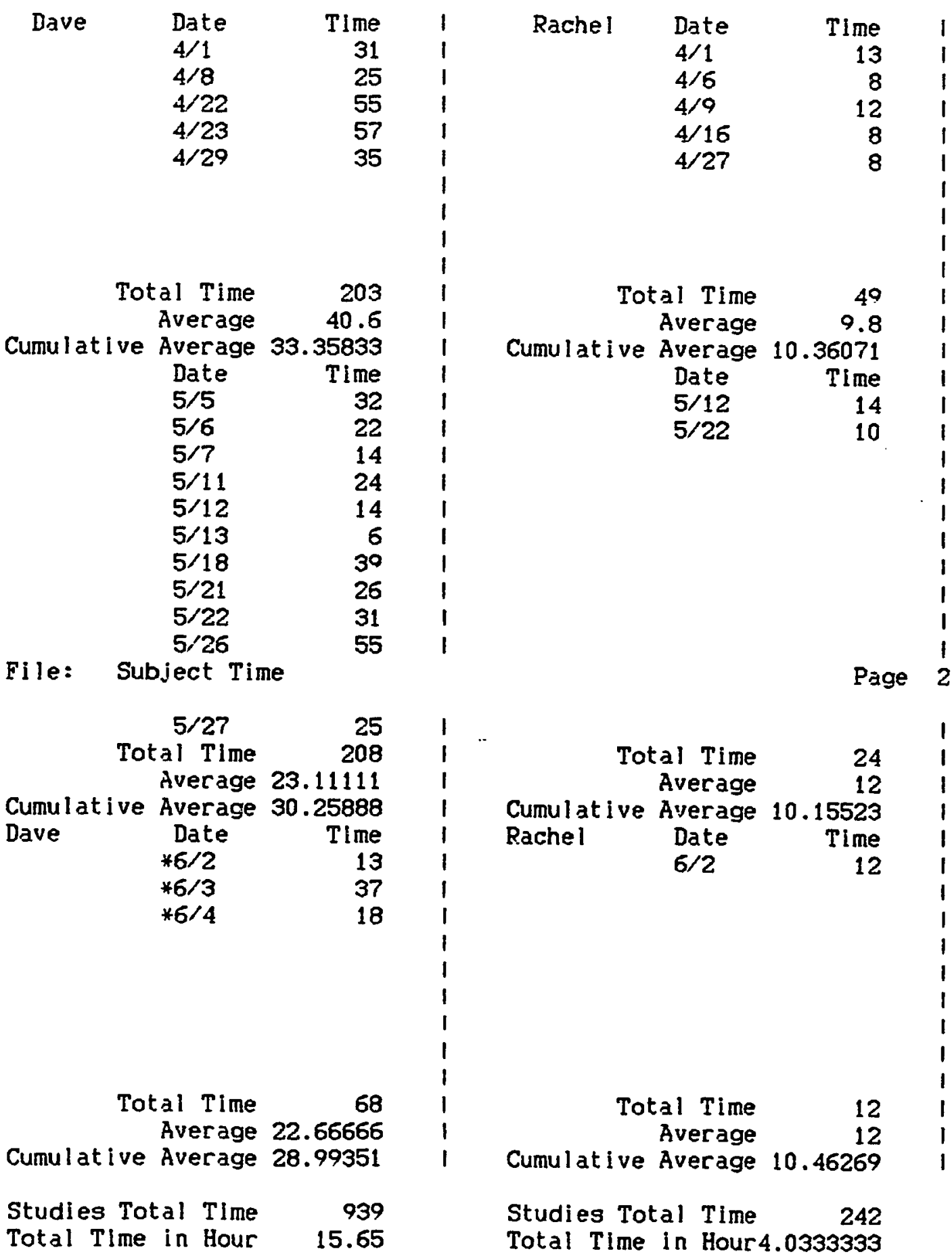




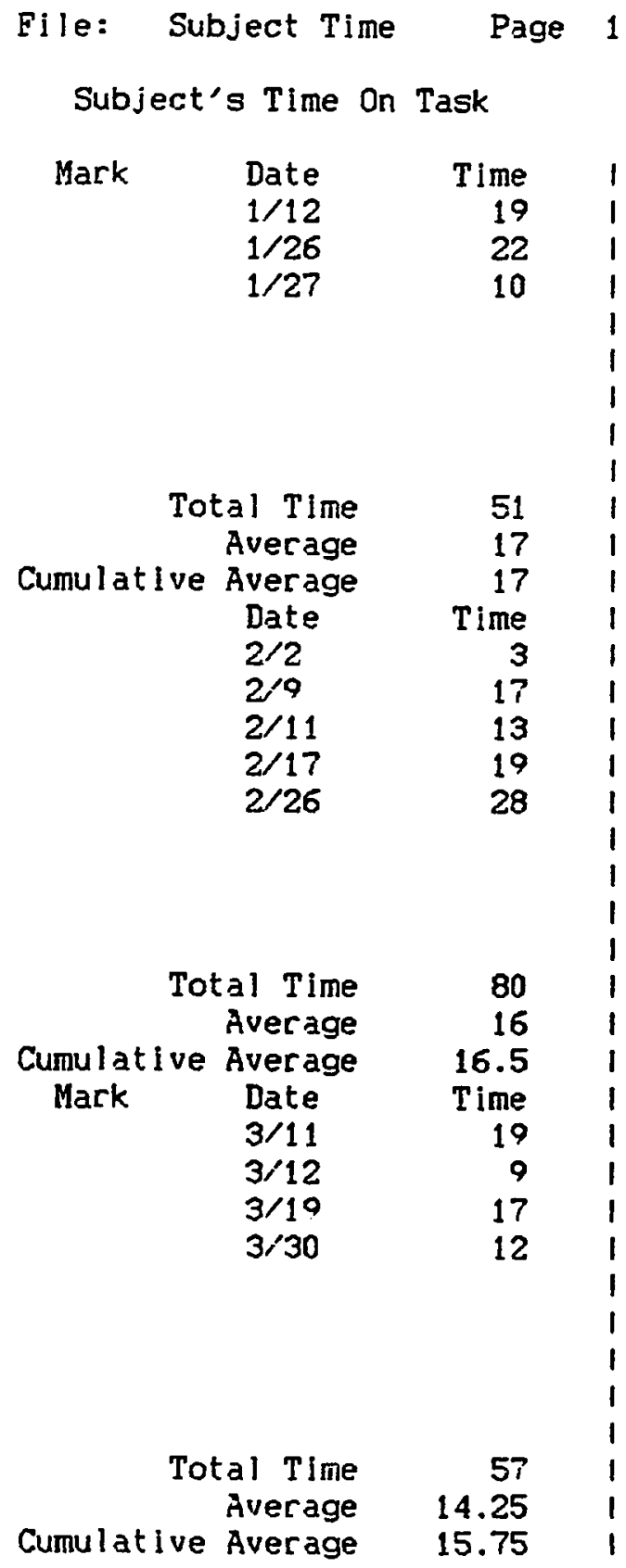




\begin{tabular}{|c|c|c|}
\hline Mark & $\begin{array}{l}\text { Date } \\
4 / 10 \\
4 / 13 \\
4 / 16 \\
4 / 20 \\
4 / 28\end{array}$ & $\begin{array}{r}\text { Time } \\
15 \\
18 \\
18 \\
23 \\
11\end{array}$ \\
\hline Cumu lat i ve & $\begin{array}{l}\text { al Time } \\
\text { Average } \\
\text { Average } \\
\text { Date } \\
5 / 4 \\
5 / 14 \\
5 / 18 \\
5,26\end{array}$ & $\begin{array}{r}85 \\
17 \\
12.8125 \\
\text { Time } \\
44 \\
57 \\
29 \\
30\end{array}$ \\
\hline
\end{tabular}

File: Subject Time

Page 2

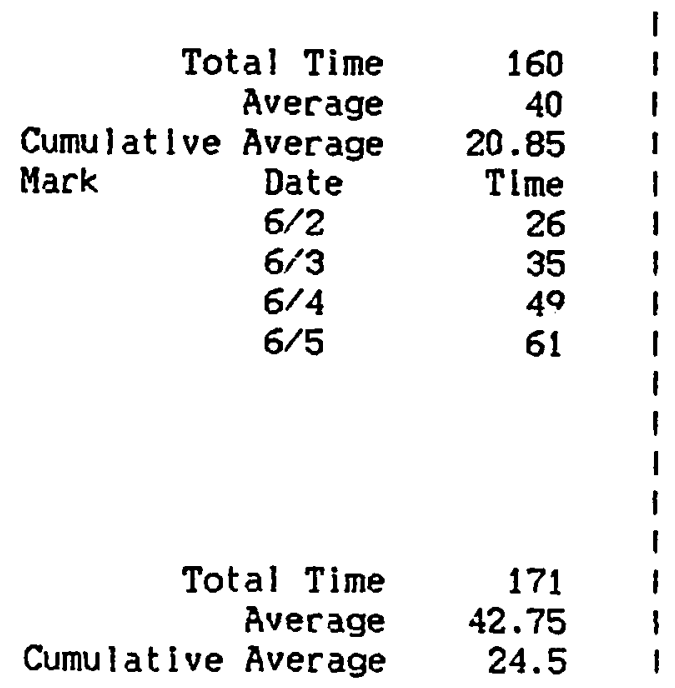

Studies Total Time $\quad 604$

Total Time in Hour 10.06666 
APPENDIX $E$

RECONEIGURED TIME ANALYSIS DATA BASE 
File: Time Analysis

Page 1

Report: Individual

Subject Month Total Time Cumulative Time

Average Cumulative Average

$\begin{array}{lrr}\text { Martha } & 1 & 53 \\ \text { Martha } & 2 & 108 \\ \text { Martha } & 3 & 62 \\ \text { Martha } & 4 & 69 \\ \text { Martha } & 5 & 86 \\ \text { Martha } & 6 & 15 \\ \text { Christy } & 1 & 98 \\ \text { Christy } & 2 & 130 \\ \text { Christy } & 3 & 98 \\ \text { Christy } & 4 & 82 \\ \text { Christy } & 5 & 30 \\ \text { Christy } & 6 & \\ \text { Dave } & 1 & 160 \\ \text { Dave } & 2 & 131 \\ \text { Dave } & 3 & 169 \\ \text { Dave } & 4 & 203 \\ \text { Dave } & 5 & 208 \\ \text { Dave } & 6 & 68 \\ \text { Rachel } & 1 & 13 \\ \text { Rachel } & 2 & 80 \\ \text { Rachel } & 3 & 64 \\ \text { Rachel } & 4 & 49 \\ \text { Rachel } & 5 & 24 \\ \text { Rachel } & 6 & 12 \\ \text { Mark } & 1 & 51 \\ \text { Mark } & 2 & 80 \\ \text { Mark } & 3 & 57 \\ \text { Mark } & 4 & 85 \\ \text { Mark } & 5 & 160 \\ \text { Mark } & 6 & 171 \\ & & \end{array}$

\section{3}

161

223

292

378

393

98

228

326

408

438

438

160

291

460

663

871

939

13

93

157

206

230

242

51

131

188

273

433

604
11

12

12

10

12

12

20

23

21

19

17

17

27

30

29

33

30

2 ?

6

10

10

10

10

10

17

16

16

13

21 
File: Time Analysis

Report: Month

Subject Month Total Time Cumulat Ive Time -

Page 1

Martha
Christy
Dave
Rachel
Mark
Martha
Christy
Dave
Rachel
Mark
Martha
Christy
Dave
Rachel
Mark
Martha
Christy
Dave
Rachel
Mark
Martha
Christy
Dave
Rachel
Mark
Martha
Christy
Dave
Rachel
Mark

53
98
160
13
51
108
130
131
80
80
62
98
169
64
57
69
82
203
49
85
86
30
208
24
160
15
68
12
171

53

98

160

13

51

161

228

291

93

131

223

326

460

157

188

292

408

663

206

273

378

438

871

230

433

393

438

939

242

604
Average Cumulative Average

$\begin{array}{rr}11 & 11 \\ 20 & 20 \\ 27 & 27 \\ 6 & 6 \\ 17 & 17 \\ 14 & 12 \\ 26 & 23 \\ 33 & 30 \\ 13 & 10 \\ 16 & 16 \\ 10 & 12 \\ 16 & 21 \\ 28 & 29 \\ 9 & 10 \\ 14 & 16 \\ 10 & 10 \\ 14 & 19 \\ 41 & 33 \\ 10 & 10 \\ 17 & 13 \\ 14 & 12 \\ 10 & 17 \\ 23 & 30 \\ 12 & 10 \\ 40 & 21 \\ 15 & 12 \\ & 17 \\ 23 & 29 \\ 12 & 10 \\ 43 & 24\end{array}$


Flle: Time Analysis

Report: Total Monthly Time

Page 1

Subject Month Total Time Cumulative Time - Average Cumulative Average

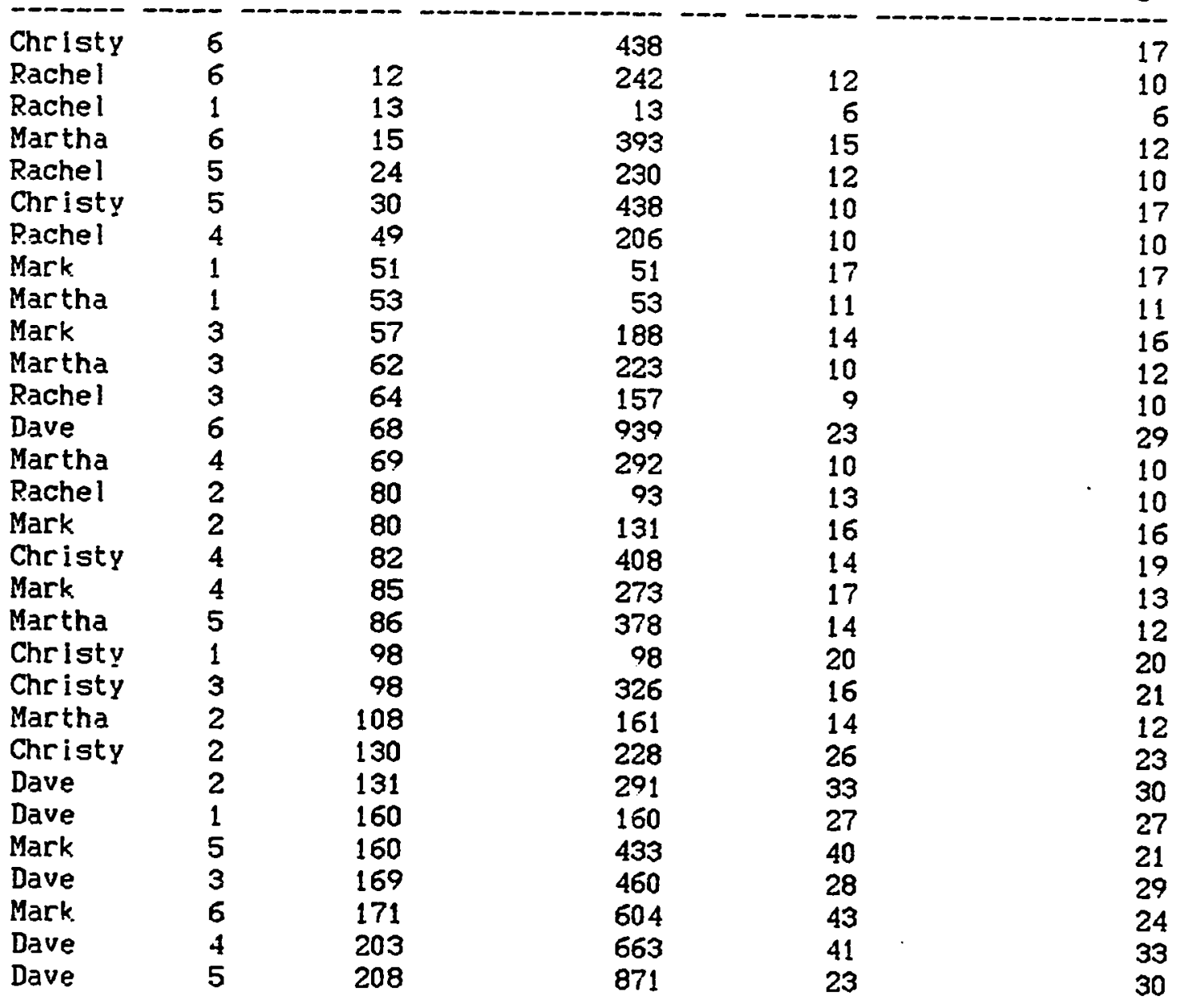


File: Time Analysis

Page 1

Report: Cumulative Monthly Time

Subject Month Total Time Cumulative Time

Average Cumulative Average

$\begin{array}{ll}\text { Rachel } & 1 \\ \text { Mark } & 1 \\ \text { Martha } & 1 \\ \text { Rachel } & 2 \\ \text { Christy } & 1 \\ \text { Mark } & 2 \\ \text { Rachel } & 3 \\ \text { Dave } & 1 \\ \text { Martha } & 2 \\ \text { Mark } & 3 \\ \text { Rache I } & 4 \\ \text { Martha } & 3 \\ \text { Christy } & 2 \\ \text { Rachel } & 5 \\ \text { Rachel } & 6 \\ \text { Mark } & 4 \\ \text { Dave } & 2 \\ \text { Martha } & 4 \\ \text { Christy } & 3 \\ \text { Martha } & 5 \\ \text { Martha } & 6 \\ \text { Christy } & 4 \\ \text { Mark } & 5 \\ \text { Christy } & 6 \\ \text { Christy } & 5 \\ \text { Dave } & 3 \\ \text { Mark } & 6 \\ \text { Dave } & 4 \\ \text { Dave } & 5 \\ \text { Dave } & 6 \\ \end{array}$

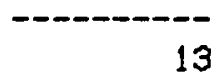

51

53

80

98

80

64

160

108

57

49

62

130

24

12

85

131

69

98

86

15

82

160

30

169

171

203

208

68
13

51

53

93

98

131

157

160

161

188

206

223

228

230

242

273

291

292

326

378

$3 \circ 3$

408

433

438

438

460

604

663

871

939

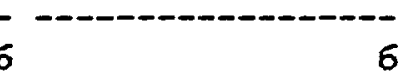

$17 \quad 17$

$11 \quad 11$

$13 \quad 10$

2020

1616

$9 \quad 10$

$27 \quad 27$

1412

14

$10 \quad 10$

$10 \quad 12$

$26 \quad 23$

1210

$12 \cdot 10$

$17 \quad 13$

$33 \quad 30$

$10 \quad 10$

1621

$14 \quad 12$

$15 \quad 12$

$14 \quad 19$

$40 \quad 21$

17

$10 \quad 17$

$28 \quad 29$

$43 \quad 24$

4133

$23 \quad 30$

$23 \quad 29$ 
Flle: Time Analysis

Page 1

Report: Monthly Average Time Per Session

Subject Month Total Time Cumulative Time

Average Cumulative Average

Christy 6

Rachel 1

Rachel 3

Rachel 4

Martha 4

Christy 5

Martha 3

Martha

Rachel 5

Rachel 6

Rachel 2

Martha 2

Christy 4

Mark 3

Martha 5

Martha 6

Mark 2

Christy 3

Mark 1

Mark 4

Christy 1

Dave 6

Dave 5

Chrlsty 2

Dave 1

Dave 3

Dave

Mark

Dave

Mark

\begin{tabular}{cc}
\hline & 13 \\
& 64 \\
4 & 49 \\
4 & 69 \\
& 50 \\
& 62 \\
& 53 \\
5 & 24 \\
6 & 12 \\
& 80 \\
2 & 108 \\
4 & 82 \\
3 & 57 \\
5 & 86 \\
6 & 15 \\
2 & 80 \\
3 & 98 \\
1 & 51 \\
4 & 85 \\
1 & 98 \\
6 & 58 \\
5 & 208 \\
2 & 130 \\
1 & 160 \\
3 & 169 \\
2 & 131 \\
5 & 160 \\
4 & 203 \\
6 & 171
\end{tabular}

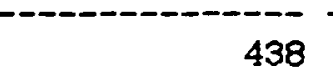

438

157

206

292

438

223

53

230

242

93

161

408

188

378

393

131

326

51

273

98

939

871

228

160

460

291

433

663

604

17

21

33

24 
File: Time Analysis

Report: Monthly Cumulatlve Average Per Session

Page 1 Subject Month Total Time Cumulative Time -

Average Cumulative Average

Rachel
Rachel
Martha
Rachel
Rachel
Rachel
Rachel
Martha
Martha
Martha
Martha
Martha
Mark
Mark
Mark
Mark
Christy
Christy
Christy
Christy
Christy
Mark
Christy
Mark
Dave
Dave
Dave
Dave
Dave
Dave

$\begin{array}{rr}13 & 13 \\ 64 & 157 \\ 69 & 292 \\ 80 & 93 \\ 24 & 230 \\ 49 & 206 \\ 12 & 242 \\ 53 & 53 \\ 62 & 223 \\ 86 & 378 \\ 108 & 161 \\ 15 & 393 \\ 85 & 273 \\ 57 & 188 \\ 80 & 131 \\ 51 & 51 \\ & 438 \\ 30 & 438 \\ 82 & 408 \\ 98 & 98 \\ 98 & 326 \\ 160 & 433 \\ 130 & 228 \\ 171 & 604 \\ 160 & 160 \\ 68 & 939 \\ 169 & 460 \\ 131 & 291 \\ 208 & 871 \\ 203 & 663 \\ & \end{array}$

\section{6}

9

10

13

12

10

12

11

10

14

14

15

17

14

16

17

10

14

20

16

40

26

43

27

23

28

33

23

41

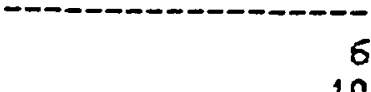

10

10

10

10

10

10

11

12

12

12

12

13

16

16

17

17

17

19

20

21

21

23

24

27

29

29

30

30

33 
APPENDIX $G$

SUBJECTS' INDIVIDUAL CHOICE DATA BASES 
File: Martha Choice

Page 1

Report: Analysis

Date Blue 1 Blue 2 Blue 3 Green 1 Green 2 Green 3 B \& W Color Choice

Jan 15

$\operatorname{Jan} 20$

$\operatorname{Jan} 21$

$\operatorname{Jan} 22$

$\operatorname{Jan} 26$

Jan 27

Feb 4

Feb 10

Eeb 12

Feb 18

Feb 19

Feb 20

Feb 23

Feb 24

Eeb 26

Mar 3

Mar 4

Mar 10

Mar 16

Mar 18

Mar 19

Mar 30

Apr 2

Apr 8

Apr 10

Apr 16

Apr 21

Apr 28

Apr 28

Apr $2^{\circ}$

Apr 30

May 6

May 12

May 18

May 19

May 21

May 26

May 27

Jun 2

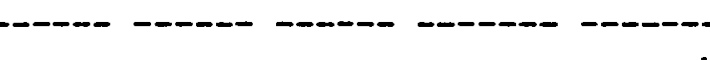

$x$

$x$

$x$

$x$

$x$

$x$
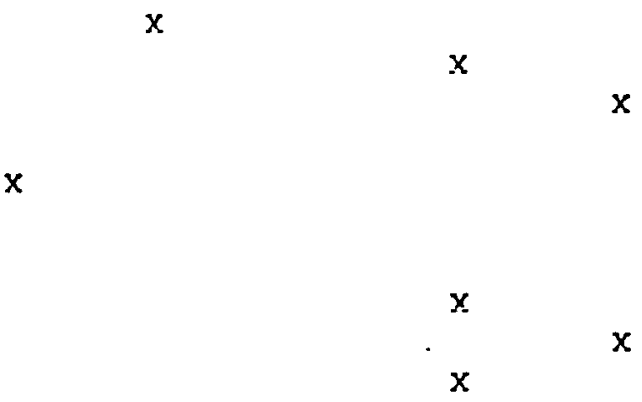

$x$

$x$

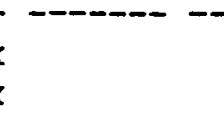

$x$

$x$

$x$

$x$

$\mathrm{x}$

$x$

$x$

$x$

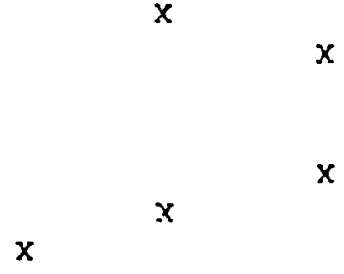

$x$

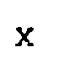

$\mathrm{x}$

$x$

$x$

$x$

$x$
$x$

$x$

$x$

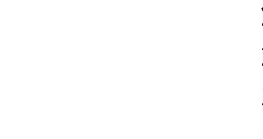

$x$

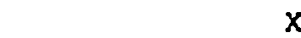

$x$

$x$

$x$

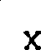

0

$x$

$\times$

$x \quad 0$

$x-0$

$x \quad 0$

$x \quad a$

$x \quad 0$

$x \quad 0$

$x \quad 0$

$x \quad 0$

$x \quad x \quad 0$

$x \quad x \quad 0$

$x \quad x$

$x \quad 0$

$\begin{array}{rl}x & 0 \\ x & 0\end{array}$

$x$

$x \quad 0$

$x \quad 0$

$x$

$\begin{array}{ll}x & 0 \\ x & 0\end{array}$

$x \quad 0$

$x \quad x \quad 0$

$\begin{array}{lll}x & x & 0 \\ x & x & 0\end{array}$

$\mathrm{x}$
$\mathrm{x}$

$x \quad 0$

$x \quad 0$

$\begin{array}{lll}\mathrm{x} & & 0 \\ \mathrm{x} & \mathrm{x} \\ x & \mathrm{x} & 0\end{array}$


File: Christy Choice

Page 1

Report: Analysis

Jin 12

Jan 13

$\operatorname{Jan} 20$

Jan 22

Jan 26

$\operatorname{Jan} 27$

Feb 10

Feb 13

Feb 18

Feb 20

Feb 26

Mar 10

Mar 11

Mar 12

Mar 16

$\operatorname{Mar} 17$

Mar 18

Mar 30

Mar 31

Mar 31

Apr 7

Apr 13

Apr 17

Apr 21

Apr 27

Apr 30

May 1

May 5

May 13

May 19
Date Blue 1 Blue 2 Blue 3 Green 1 Green 2 Green 3 B \& W Color Choice

\section{$x$}

$x$

$x$

$\mathrm{x}$

$x$

$x$

$x$

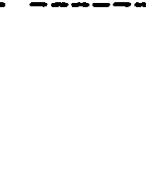

$x$

$x$

$x$

$x$

$x$
$x$

$x$

$x$

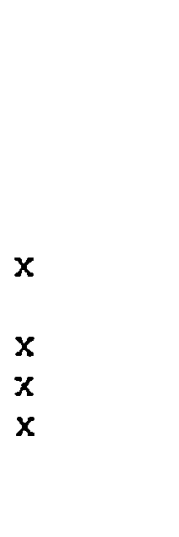

$x$

$x$

$\mathrm{x}$

$x$

$x$

$x$

$x$

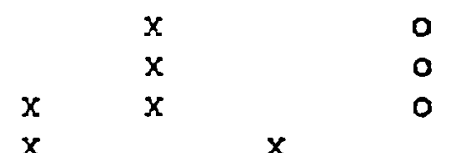

$x \quad x$

$x \quad x \quad 0$

$\mathrm{x} \quad 0$

$x \quad x \quad 0$

$\begin{array}{lll}x & x & 0\end{array}$

$\mathrm{x}$

$\mathrm{x}$

$x$

$\begin{array}{ccc} & \mathrm{x} & 0 \\ & \mathrm{x} & 0 \\ \mathrm{x} & & 0 \\ \mathrm{x} & & 0 \\ & \mathrm{x} & 0 \\ \mathrm{x} & & 0 \\ \mathrm{x} & & 0 \\ \mathrm{x} & & 0 \\ & \mathrm{x} & 0 \\ \mathrm{x} & \mathrm{x} & 0 \\ & & 0\end{array}$

$x \quad 0$

$x \quad 0$


Flle: Dave Choice

Page 1

Report: Analysis

Date Blue 1 Blue 2 Blue 3 Green 1 Green 2 Green 3 B \& W Color Choice

\begin{tabular}{|c|c|c|c|c|c|c|c|c|c|}
\hline Jan & 13 & $x$ & & & & & & & $x$ \\
\hline $\operatorname{Jan}$ & 14 & & & & & $x$ & & $x$ & \\
\hline $\operatorname{Jan}$ & 20 & $x$ & & & & & & $x$ & \\
\hline Jan & 21 & $x$ & & & & & & & $x$ \\
\hline Jan & 22 & & & & & $x$ & & & $x$ \\
\hline $\operatorname{Jan}$ & 27 & $x$ & & & & & & & $x$ \\
\hline Jan & 29 & $x$ & & & & & & & $x$ \\
\hline Feb & 4 & $x$ & & & & & & $x$ & \\
\hline Feb & 11 & & & & & $x$ & & $x$ & \\
\hline Feb & 17 & $\ddot{x}$ & & & & & & & $x$ \\
\hline Feb & 17 & $x$ & & & & & & & $x$ \\
\hline Feb & 18 & $x$ & & & & & & $x$ & \\
\hline Feb & 23 & $x$ & & & & & & & $x$ \\
\hline Fed & 26 & $x$ & & & & & & & $x$ \\
\hline Mar & 3 & & $x$ & & & & & & $x$ \\
\hline Mar & 11 & $x$ & & & & & & $x$ & \\
\hline Mar & 17 & $x$ & & & & & & & $x$ \\
\hline Mar & 18 & & $x$ & & & & & & $x$ \\
\hline Mar & 31 & $x$ & & & & & & & $x$ \\
\hline Āpr & 1 & $x$ & & & & & & & $x$ \\
\hline Aेpr & 2 & & $x$ & & & & & & $x$ \\
\hline Apr & 8 & & $x$ & & & & & & $x$ \\
\hline Apr & 22 & & & & & $x$ & & & $x$ \\
\hline Apr & 23 & & $x$ & & & & & $x$ & \\
\hline Apr & 27 & & & & & $x$ & & $x$ & \\
\hline Apr & 29 & & & & $x$ & & & & $x$ \\
\hline Apr & 29 & & & $x$ & & & & $x$ & \\
\hline May & 5 & $x$ & & & & & & $x$ & \\
\hline May & 6 & & & & & $x$ & & & $x$ \\
\hline May & 7 & & & & $x$ & & & $x$ & \\
\hline May & 11 & & & & & & $x$ & & $x$ \\
\hline May & 12 & $x$ & & & & & & $x$ & \\
\hline May & 13 & & & $x$ & & & & $x$ & \\
\hline May & 19 & & & & & & $x$ & & $x$ \\
\hline May & 19 & & & $x$ & & & & $x$ & \\
\hline May & 21 & & & & $x$ & & & $x$ & \\
\hline May & 22 & & $x$ & & & & & $x$ & \\
\hline May & 22 & & & & & & $x$ & $x$ & \\
\hline May & 26 & & $x$ & & & & & & $x$ \\
\hline May & 27 & & & & $x$ & & & $x$ & \\
\hline Jun & 2 & & & & $x$ & & & & $x$ \\
\hline Jun & 3 & $x$ & & & & & & & $x$ \\
\hline Jun & 4 & & & & & $x$ & & $x$ & $\hat{\lambda}$ \\
\hline
\end{tabular}


File: Rachel Cholce

Page 1

Report: Analysis

Date Blue 1 Blue 2 Blue 3 Green 1 Green 2 Green 3 B \& W Color Choice

Jan 14

Jari 20

Jan 21

Jan 29

Feb 2

Feb 3

Eeb 9

Feb 12

Feb 18

Feb 19

Feb 26

Mar 3

Mar 4

Mar 12

Mar 17

Mar 19

Mar 30

Apr 1

Apr 6

Apr 9

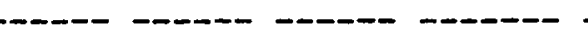

$x$

$x$
$x$

Apr 16

Apr 27

Ape 30

May 12

May 22

Jun 2

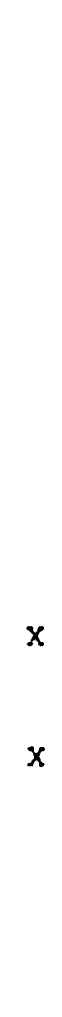

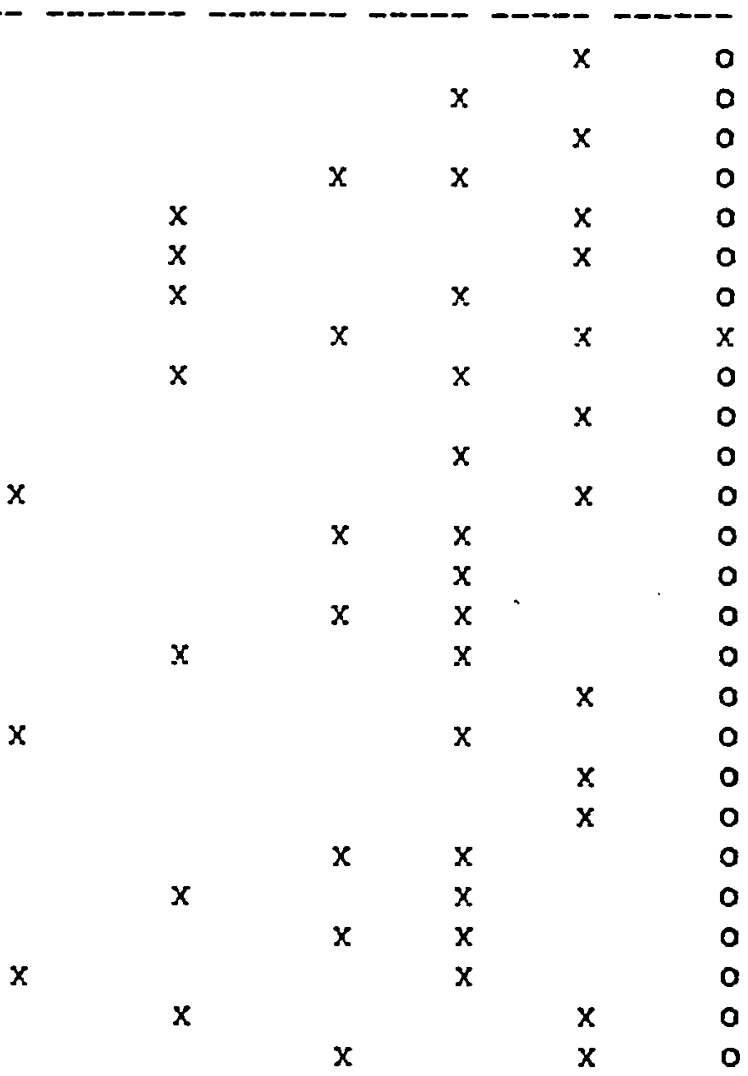


File: Mark Choice

Page 1

Report: Analysis

Date Blue 1 Blue 2 Blue 3 Green 1 Green 2 Green 3 B \& W Color Choice

Jan 12

Jan 22

$\operatorname{Jan} 26$

Jan 27

Feb 2

Feb 3

Feb 9

Feb 11

Feb 17

Feb 26

Mar 4

Mar 11

Mar 12

Mar 19

Mar 30

Apr 10

Apr 13

Apr 16

Apr 20

Apr 28

May 4

May 14

May 14

May 18

May 26

Jun 2

Jun 3

Jun 4

Jun 5
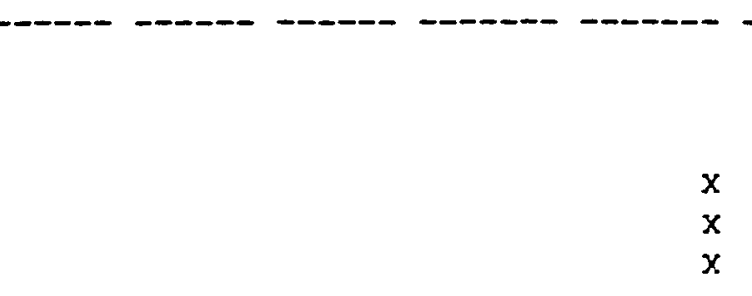

$\mathrm{x}$

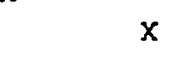

$x$

$x$

$x$

$x$

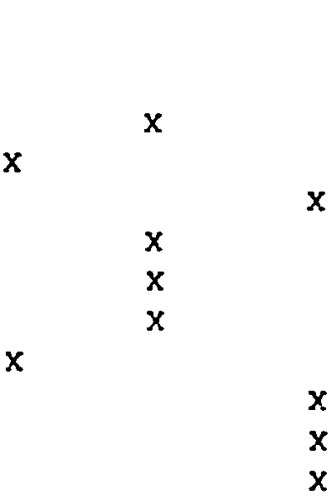

$x$

$x$ $x$

$x$

$x$

$x \quad x$

$x \quad x \quad x$

$x \quad x \quad 0$

$x \quad 0$

$x \quad 0$

$x$

$x$

$x \quad 0$

$x \quad 0$
$x \quad 0$

$x \quad x \quad 0$

$x \quad 0$

$x \quad 0$

$\begin{array}{ll}x & 0 \\ x & 0\end{array}$

$x$
$x$
$x$

$x$

$\begin{array}{ccc} & \mathrm{x} & 0 \\ & \mathrm{x} & 0 \\ & \mathrm{x} & 0 \\ \mathrm{x} & \mathrm{x} & 0 \\ & \mathrm{x} & 0 \\ \mathrm{x} & \mathrm{x} & \mathbf{0} \\ & \mathrm{x} & \mathbf{0} \\ & \mathrm{x} & \mathbf{0} \\ & \mathrm{x} & \mathrm{o}\end{array}$


APEEIDIX H

SUBJECTS' INDIVIDUAL PRINTER DATA BASES 
Plle: PubChart Martha

Page 1

Report: Analysis

Date by adult by peer with adult with peer by self \# shared with

$\operatorname{Jan} 15$

Jan 21

Jan 22

$\operatorname{Jan} 26$

Jan 27

Peb 4

Feb 10

Feb 12

Feb 18

Feb 20

Feb 20

Feb 23

Peb 24

Feb 26

Mar 3

Mar 4

Mar 10

$\operatorname{Mar} 16$

Mar 18

$\operatorname{Mar} 10$

Mar 30

Apr 2

Apr 8

Apr 10

Apr 16

Apr 21

Apr 28

Apr 28

Apr 28

Apr 29

Apr 30

May 6

Hay 6

May 12

May 18

May 19

May 21

May 27

Jun 2

\section{X}

$x$

$x$

$x$

$x$

$\mathbf{X}$

$x$

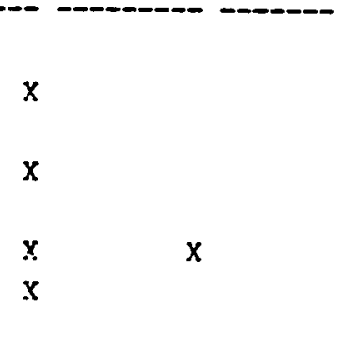

$\mathrm{x}$

$x$

$x$

$x$

$x$
1

$\times 1$

$\times 1$

2

$\times 1$

$\times 1$

$\times 1$

$x 1$

$\times 1$

$\times 1$

$x 1$ print screen

print screen

$\times 1$

$\times 1$

$\times 1$

$\times 2$

$x \perp$ copy for Rathy

$x 2$ 2nd story

$x 3$ me, self, display

$\times 2$

$\times 1$

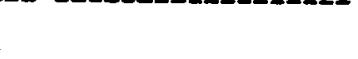

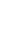

moved to CAI

(1)

1 Hazel wanted one

$x 1$ grandma

$\times 1$

$x 0$ out of time

$x$ 2-5 others

$x 1$

$\times 1$ 
Flle: PubChart Christy

Page 1

Report: Analysis

Date by self by peer by adult with peer with adult \# shared with

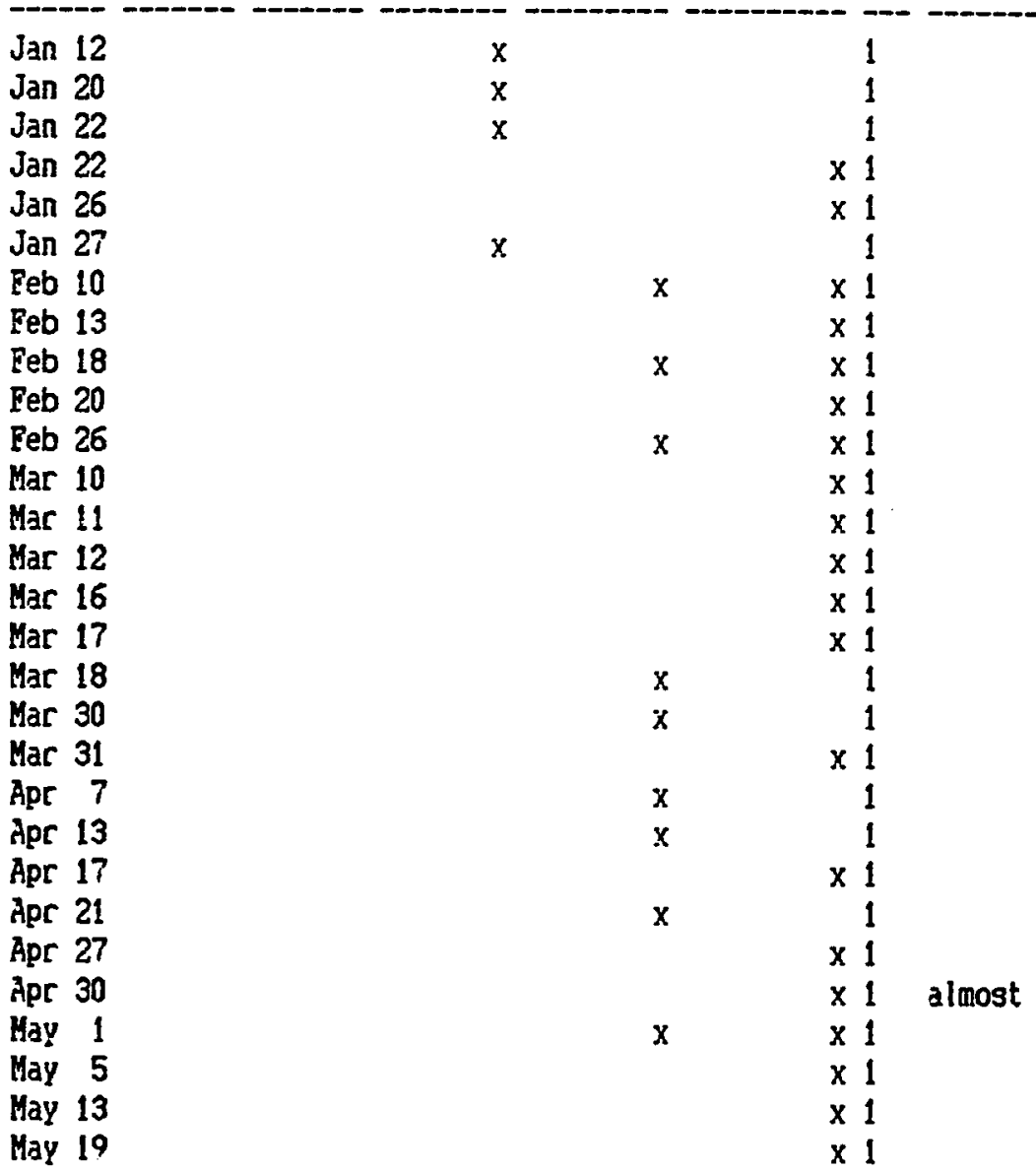


File: PubChart Dave

Page 1

Report: Analysis

Date by adult by peer with adult with peer by self \# shared with

\begin{tabular}{|c|c|c|c|c|}
\hline & & & & \\
\hline $\operatorname{Jan} 13$ & & $x$ & 1 & \\
\hline $\operatorname{Jan} 14$ & $x$ & & 1 & \\
\hline $\operatorname{Jan} 20$ & & $x$ & 1 & \\
\hline $\operatorname{Jan} 21$ & & $x$ & 1 & \\
\hline $\operatorname{Jan} 22$ & $x$ & & 1 & \\
\hline Jan 27 & & $\mathrm{x}$ & 1 & \\
\hline $\operatorname{Jan} 29$ & & & $\times i$ & \\
\hline Feb 4 & & $x$ & 1 & \\
\hline Peb 11 & & & $\times i$ & \\
\hline Feb 17 & & $\mathrm{x}$ & 1 & \\
\hline Reb 18 & & & $\times i$ & \\
\hline Feb 23 & & & $\times 1$ & \\
\hline $\operatorname{Mar} 2$ & & & $\times 1$ & \\
\hline Mar 3 & & & $\times 6$ & in his home \\
\hline Mar 11 & & & $\times 1$ & \\
\hline Mar 17 & & & $\times 1$ & \\
\hline Mar 19 & & $x$ & 1 & print screen \\
\hline $\operatorname{Mar} 26$ & & & $\times 1$ & \\
\hline Mar 31 & & $x$ & 3 & reg. prt scrn. me \\
\hline Apr 1 & & $\mathrm{x}$ & 5 & prt scrn-friends \\
\hline Apr 2 & & & $\times 1$ & prt scrn, me \\
\hline Apr 8 & & & $\times i$ & \\
\hline Apr 22 & & & & saved \\
\hline Apr 23 & & $\mathrm{x}$ & 1 & \\
\hline Apr 29 & & & $\times 0$ & *cleared* \\
\hline May 5 & & & $\times 2$ & 1 mistake \\
\hline May 6 & & & $\times 1$ & print screen \\
\hline May 7 & & & $\times 1$ & print screen \\
\hline Hay 11 & & & $\times 1$ & print screen \\
\hline May 11 & & $x$ & 2 & prt scrn-flles lis \\
\hline May 12 & & & $\times 2$ & me \\
\hline Hay 13 & & & $\times 1$ & \\
\hline May 21 & & & $x 1-5$ & helping others \\
\hline May 22 & & & $\times 2$ & reg. prt scrn \\
\hline May 26 & & & $\times 1$ & received copy-Matt \\
\hline Hay 27 & & & $\hat{x} 1$ & \\
\hline Jun 2 & & & & saved \\
\hline Jun 3 & & & & saved \\
\hline Jun 4 & & & & saved \\
\hline
\end{tabular}


File: PubChart Rachel

Page 1

Report: Analysis

Date by adult by peer with adult with peer by self \# shared with

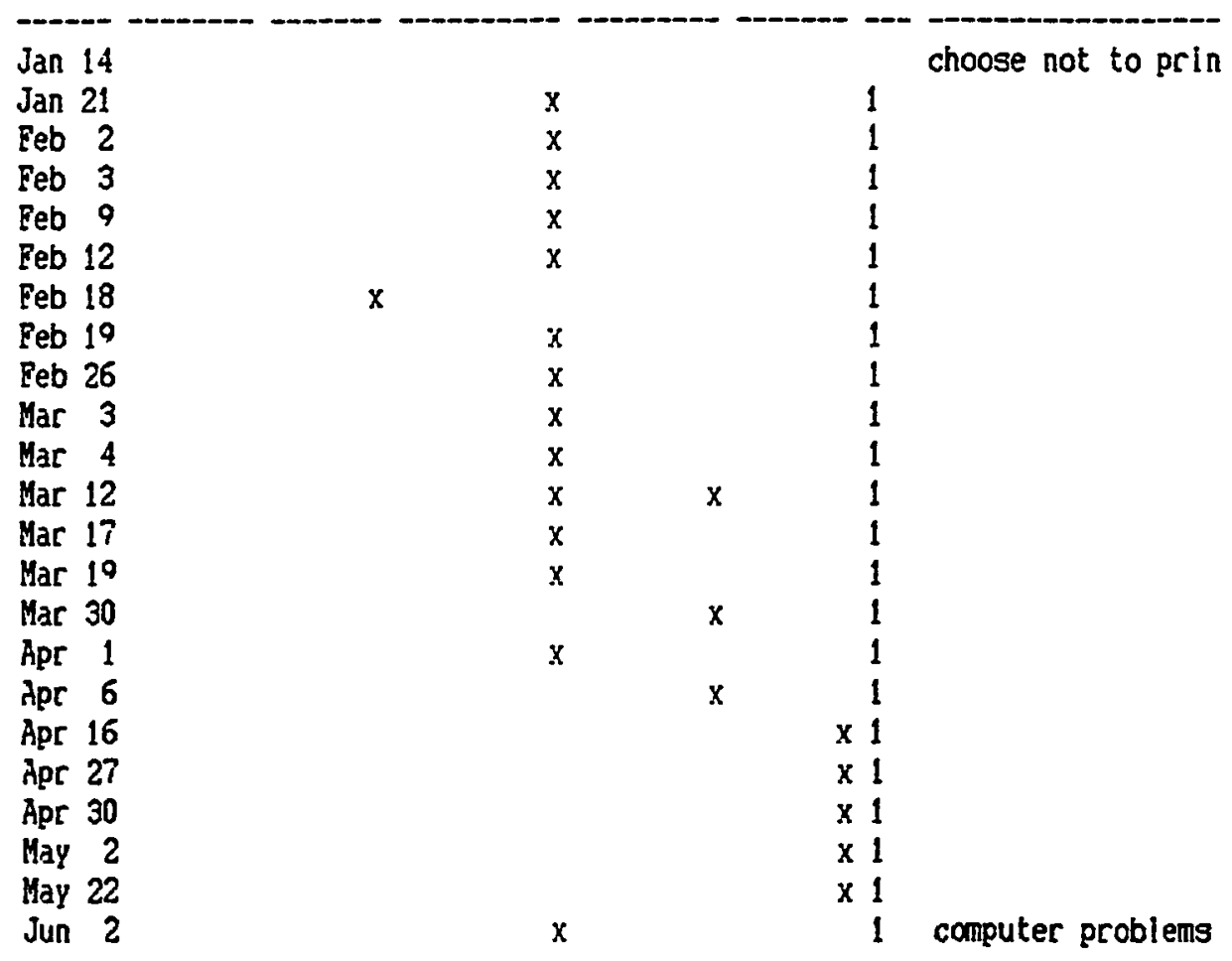


File: PubChart Mark

Page 1

Report: Analysis

Date by self by peer by adult with peer with adult \# shared with

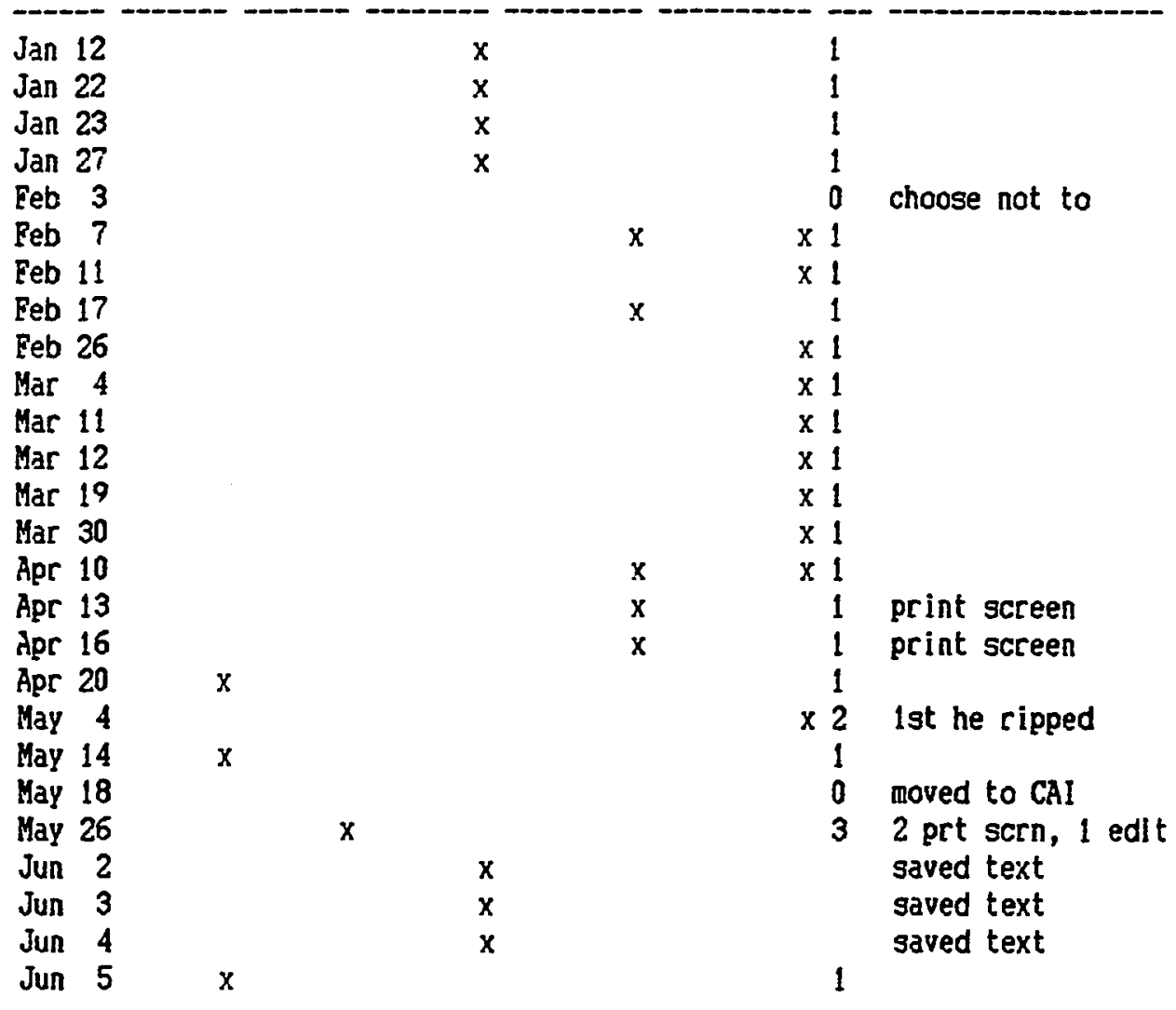


314

APEENDIX I

SUBJECTS' INDIVIDUAL LETTER CHOICE DATA BASES 


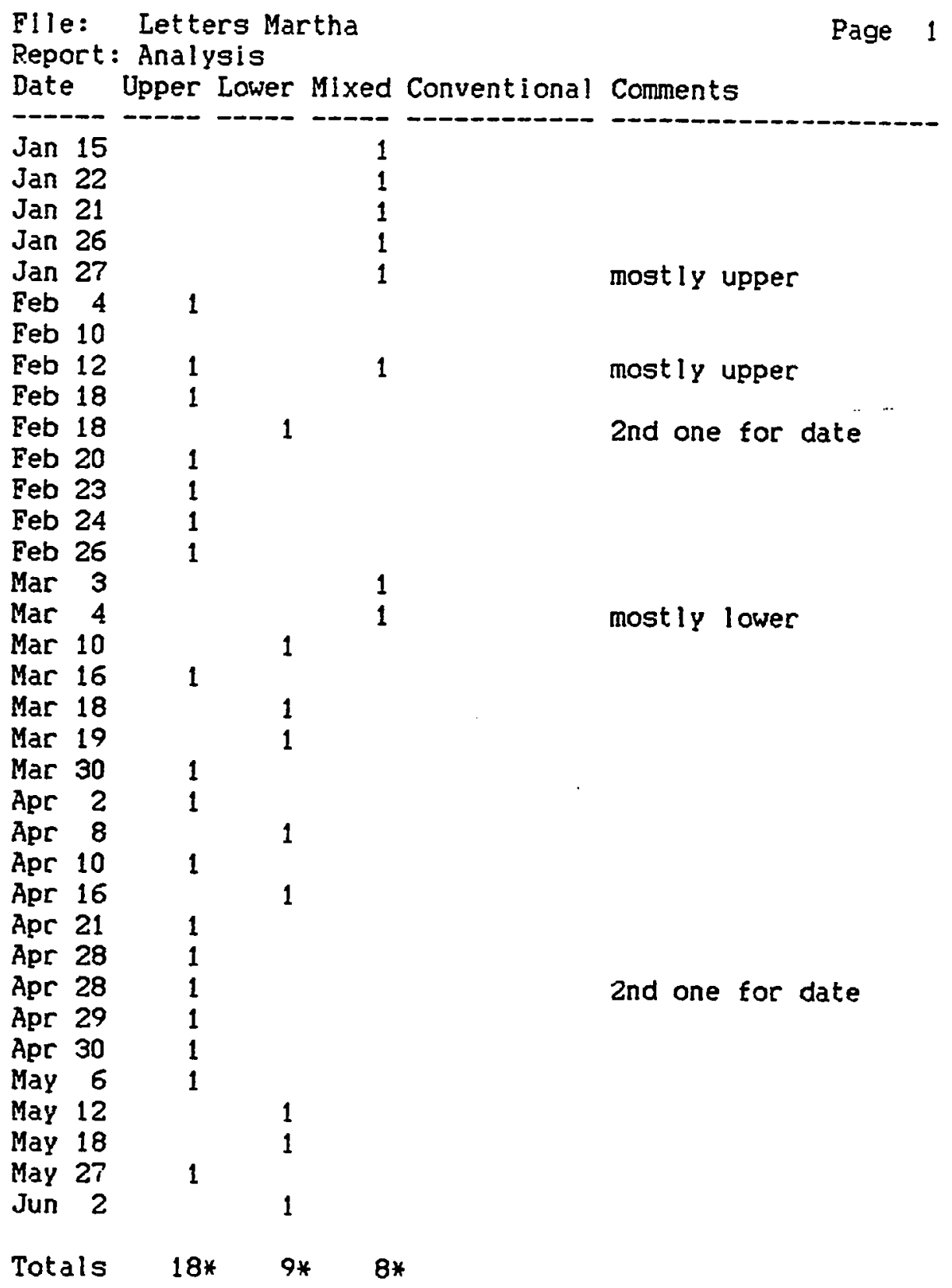




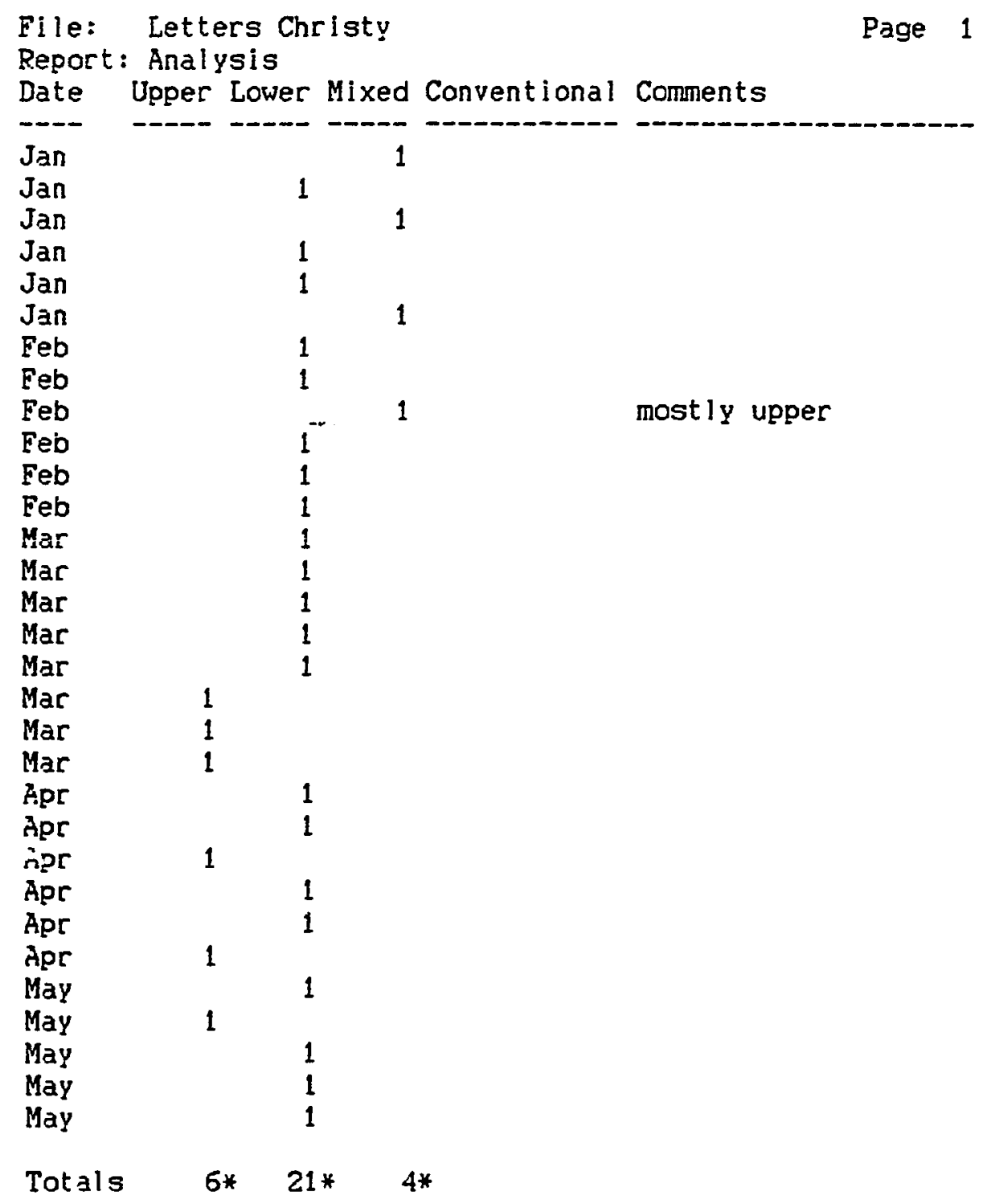




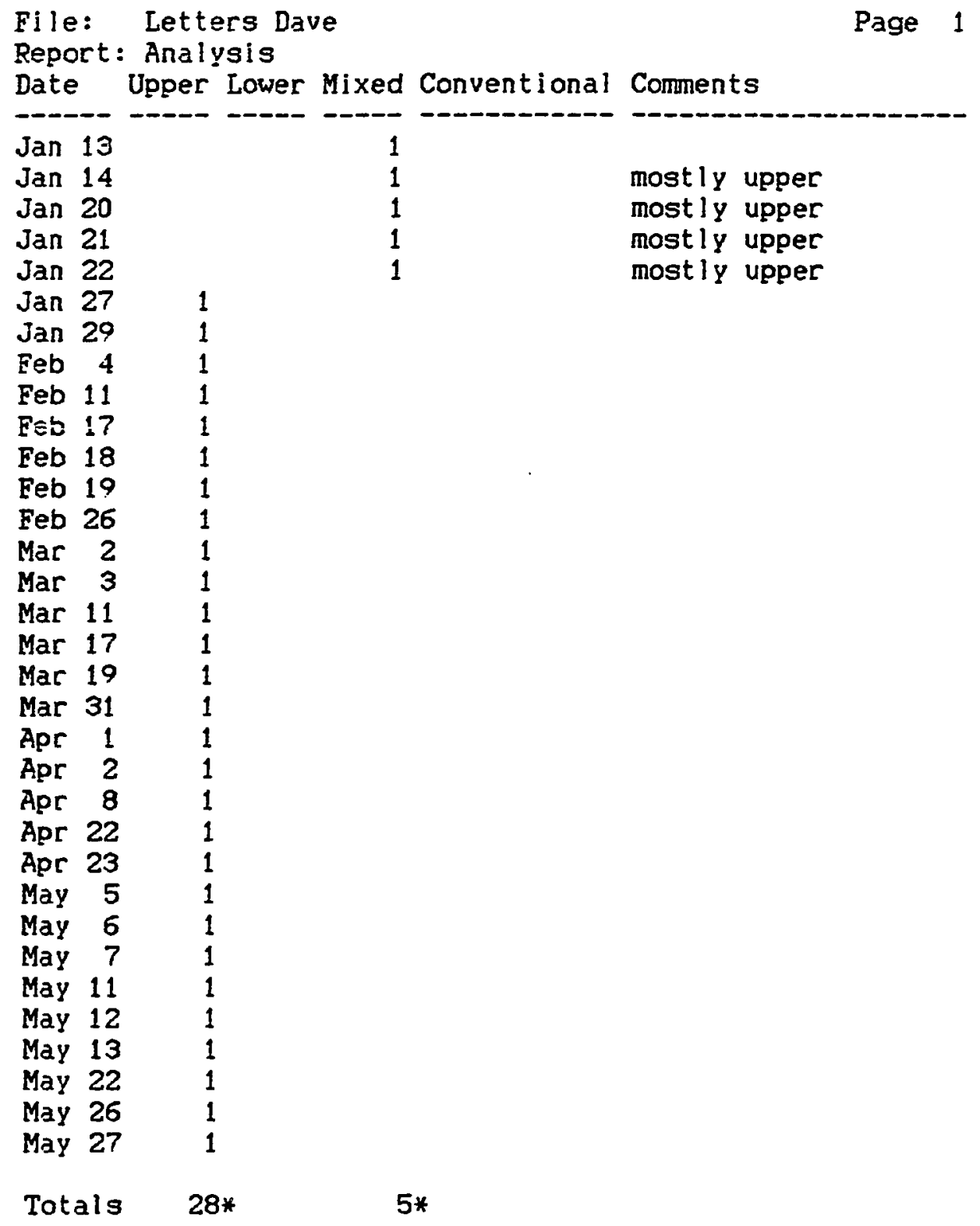


File: Letters Rachel

Page 1

Report: Analysis

Date Upper Lower Mixed Conventional Comments

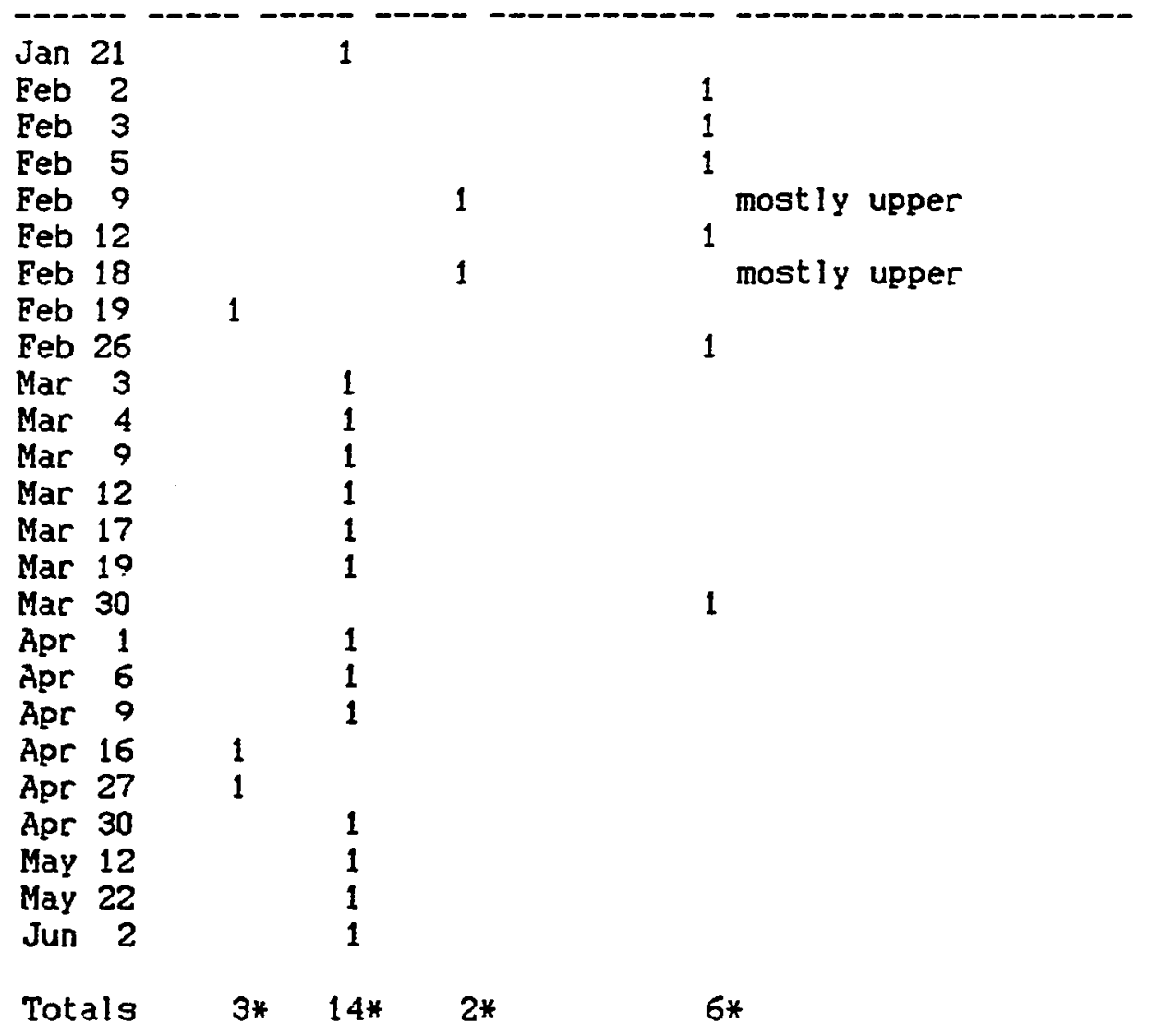




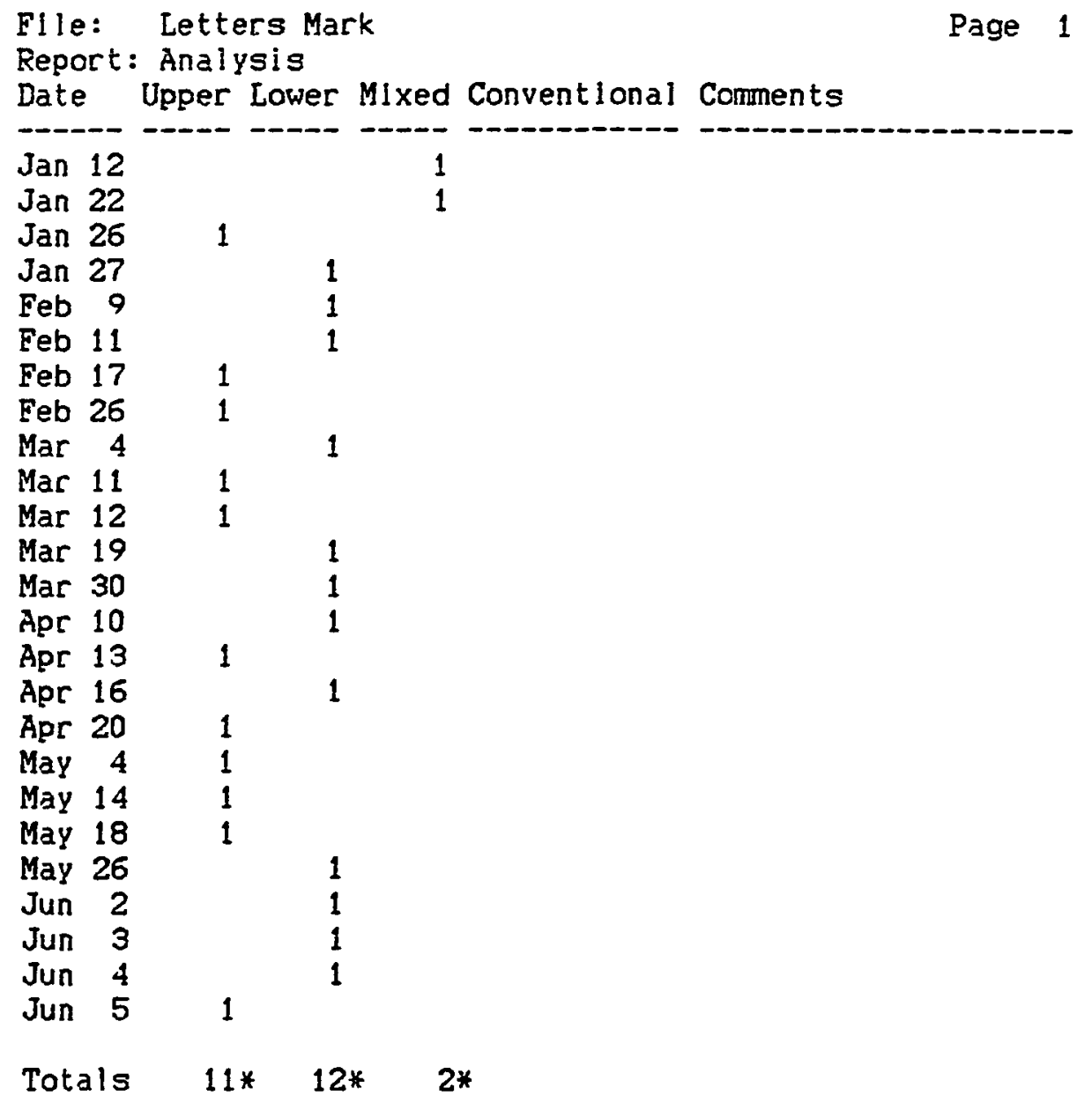


320

APPENDIX J SUBJECTS' AGES 
Ages of subjects:

$\begin{array}{lccc} & \text { Day } & \text { Month } & \text { Year } \\ \text { Martha } & 20 & 2 & 81 \\ \text { Christy } & 1 & 7 & 81 \\ \text { Dave } & 10 & 10 & 80 \\ \text { Rachel } & 18 & 8 & 81 \\ \text { Mark } & 1 & 12 & 80 \\ \text { Malcom } & 4 & 12 & 80\end{array}$

Research conducted over a period of 4 months and 23 days.

\begin{tabular}{|c|c|c|c|c|c|c|c|c|c|}
\hline \multicolumn{2}{|c|}{$\begin{array}{l}\text { Beginning Date } \\
\text { Ending Date }\end{array}$} & \multicolumn{4}{|c|}{$\begin{array}{r}12 / 1 / 87 \\
5 / 6 / 87\end{array}$} & \multirow[b]{2}{*}{ Beg. Age } & & & \multirow[b]{2}{*}{ End Age } \\
\hline & Day & Month & & $\mathrm{Ye}$ & $a r$ & & & & \\
\hline Martha & 20 & 2 & & 8 & 1 & $12 / 1 / 5$ & & & $15 / 3 / 6$ \\
\hline Ohristy & 1 & 7 & & 8 & 1 & $11 / 6 / 5$ & & & $4 / 11 / 5$ \\
\hline Dave & 10 & 10 & & & 30 & $2 / 3 / 6$ & & & $25 / 7 / 6$ \\
\hline Rachel & 18 & 8 & & & 31 & $14 / 4 / 5$ & & & $17 / 9 / 5$ \\
\hline Mark & 1 & 12 & & & 30 & $11 / 1 / 6$ & & & $4 / 6 / 6$ \\
\hline Malcon & 4 & 12 & & & 30 & $8 / 1 / 6$ & & & $1 / 6 / 6$ \\
\hline \multicolumn{10}{|c|}{$\begin{array}{l}\text { Chronological Order } \\
\text { Oldest to Youngest }\end{array}$} \\
\hline Name & & \multicolumn{4}{|c|}{$\begin{array}{l}\text { Beg, Age } \\
\text { Yr.Mo.Dy. }\end{array}$} & \multicolumn{3}{|c|}{$\begin{array}{l}\text { End. Age } \\
\text { Yr. Mo.DY. }\end{array}$} & \\
\hline Dave & & & 6 & 3 & 2 & 6 & 7 & 25 & \\
\hline Mark & & & 6 & 1 & 11 & 6 & 6 & 4 & \\
\hline Martha & & & 5 & 10 & 12 & 6 & 3 & 15 & \\
\hline Christy & & & 5 & 6 & 11 & 5 & 11 & 4 & \\
\hline Rachel & & & 5 & 4 & 14 & 5 & 9 & 17 & \\
\hline
\end{tabular}


APEENDIX K

GENERIC FORMS FOR PARENT CONCENT 
March 16, 1987

Dear Mrs.

Your daughter Martha is one of the subjects of a research study I am completing as a degree requirement at Portland. State Unlversity. Ms. Bartell suggested Martha and five other students as candidates for this research.

This study consists of my observing kindergarten student's behavior associated with a word processor. As I observe students using this writing tool or interacting with others I record what I see. I do this by writing notes about the actlvity either with pencil and paper or with a word processor. At the end of my daily observations I often record additional thoughts about what I have seen.

Martha's participation in this study may or may not be of any direct benefit to her. However, her involvement may help to increase knowledge whlch may benefit other children in the future.

You are welcome to visit the WTR 1 ab and observe my involvement there anytime. If you have questions now or in the future please feel free to contact me at Sabin in person, by note or by phone, 280-6181.

Would you please read, date and sign the attached Informed Consent form. Enclosed is an envelope for returning the consent form to me.

research.

I appreclate your help and cooperation with this

Sincerely,

Paul Steger 


\section{INFORMED CONSENT}

I understand that my daughter, Martha XXXX, is a subject in the research project on the use of word processors by kindergarten chlldren titled: An Analysis of kindergarten children's use of a word processor in their print literacy development, conducted by Paul steger.

I understand that this study involves the observation of my child and others as they use a word processor when visiting the writing lab at Sabin ECEC and the collecting and analysis of their computer generated compositlons.

It has been explained to me that the purpose of this study is to analyze the 1 iteracy environment and manner in which kindergarten children use a word processor.

I also understand that my child may not receive any direct benefit from particlpation in this study, but his/her participation may help to increase knowledge which may benefit other chlldren in the future.

Paul Steger has offered to answer any questions I may have about thls study and can reach him at Sabin or by phone, 280-6181. I have been assured that all information will be kept confidential and that the identity of all subjects will remain anonymous.

I have read and understand the foregoing Information.

Date

Signature

If you experience problems that are the result of your child's particlpation in this study, please contact Robert Tinnin, Office of Graduate Studies and Research, 105 Neuberger Hall, Portland State Unlversity, 229-3423. 
APPENDIX I

STUDY CALENDAR 


\begin{tabular}{|c|c|c|c|}
\hline Week. \# & Month & Days & Comments \\
\hline- & January & $5,6,7,8,9$ & First week after Holidays \\
\hline 1 & January & $12,13,14,15,16$ & Begin Data Collection \\
\hline 2 & January & $x, 20,21,22, x$ & MLK Day, Teacher Plan Day \\
\hline 3 & January & $26,27,28,29,30$ & - \\
\hline 4 & February & $2,3,4,5,6$ & - \\
\hline 5 & February & $9,10,11,12,13$ & - \\
\hline 6 & Eebruary & $x, 17,18,19,20$ & President's Day \\
\hline 7 & February & $23,24,25,26,27$ & - \\
\hline 8 & March & $2,3,4,5,6$ & - \\
\hline 9 & March & $9,10,11,12,13$ & - \\
\hline 10 & March & $16,17,18,19,20$ & - \\
\hline- & March & $23,24,25,26,27$ & Spring Break \\
\hline 11 & March/Apri & $30,31,1,2, x$ & Teacher Plan Day \\
\hline 12 & Apr \lfloor & $6,7,8,9,10$ & - \\
\hline 13 & Apr il & $13,14,15,16,17$ & - \\
\hline 14 & April & $20,21,22,23,24$ & - \\
\hline 15 & Apr i l/May & $27,28,29,30,1$ & - \\
\hline 16 & May & $4,5,6,7,8$ & - \\
\hline 17 & May & $11,12,13,14, x$ & Writing Festlval \\
\hline 18 & May & $18,19,20,21,22$ & - \\
\hline 19 & May & $x, 26,27,28, x$ & Memorlal Day, Literacy Inservice \\
\hline 20 & June & $1,2,3,4,5$ & Data Collection Completed \\
\hline
\end{tabular}

